DRAFT

\title{
Long-Term-Consequence Analysis of No Action Alternative 2
}

Support Information for the Waste Isolation Pilot Plant

Disposal-Phase Supplemental Environmental Impact Statement
J. W. Buck
K. J. Castleton
L. M. Bagaasen
G. M. Gelston
M. P. Bergeron
D. L. Strenge
G. P. Streile
K. M. Krupka
L. H. Staven
R. J. Serne

July 1996

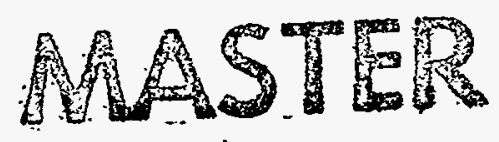

Prepared for

the U.S. Department of Energy

under Contract DE-AC06-76RLO 1830

Pacific Northwest National Laboratory

Richland, Washington 99352 



\section{DISCLAIMER}

Portions of this document may be illegible in electronic image products. Images are produced from the best available original document. 


\section{Summary}

This report is a supplement to the Waste Isolation Pilot Plant Disposal-Phase Supplemental Environmental Impact Statement (SEIS-II). Described herein are the underlying information, data, and assumptions used to estimate the impacts from postulated long-term releases of radionuclides and hazardous constituents from transuranic (TRU) wastes stored at major generator/storage sites after loss of institutional control (i.e., No Action Alternative 2).

Under No Action Alternative 2, TRU wastes would not be emplaced at the Waste Isolation Pilot Plant during the disposal phase but would remain at each generator site in a stable storage configuration. To analyze this alternative, the long-term environmental consequence of radionuclides and hazardous materials stored at generator sites after the loss of institutional control was examined. In the analysis, the environmental and human-health impacts were estimated at 7 of the 10 major generator/storage sites: Hanford Site, Idaho National Engineering Laboratory, Lawrence Livermore National Laboratory, Los Alamos National Laboratory, Oak Ridge National Laboratory, Rocky Flats Environmental Technology Site, and Savannah River Site. The analysis focused on these 7 major sites. because $99 \%$ of the estimated TRU waste volume and inventory will be generated/stored there. Other sites considered but not examined in this analysis include Argonne National Laboratory, Mound Site, and Nevada Test Site.

The general approach uses, to the extent possible, environmental data sets and models used for the consequence analysis of low-level and low-level-mixed wastes developed for the Draft Waste Management Programmatic Environmental Impact Statement for Managing Treatment, Storage, and Disposal of Radioactive and Hazardous Wastes. The human-health impacts from exposure to TRU waste were estimated for two scenarios: 1) exposure from inadvertent human intrusion into areas of TRU waste storage and 2) long-term exposure from source-term releases to surface and subsurface environmental exposure points.

Estimation of risk from human intrusion considered driller, gardener, scavenger, and farm family exposure scenarios. To assess the dose and risk from these human intrusions, a unit methodology was employed. Radiological impacts were assessed using the GENII computer code. The impacts from carcinogen and noncarcinogen hazardous chemicals were assessed using the Multimedia Environmental Pollutant Assessment System (MEPAS) computer code.

Long-term exposures from source-term releases to the surface and subsurface environmental receptor points considered a downgradient farm family groundwater receptor, receptors from airborne releases, and drinking-water receptors from releases to surfacewaters. This analysis used a modular risk assessment methodology. Source-term-release and environmental transport calculations of major radiological and hazardous chemical components from TRU wastes were done using the MEPAS 
computer code. MEPAS results were then used as input to the exposure models of the GENII computer code to calculate the human-health impacts for major radionuclides. Exposure models in the MEPAS code were used to calculate human-health impacts from carcinogenic and noncarcinogenic hazardous chemicals.

Of all the intruder scenarios, the farm family intruder scenario estimated impacts are at least 2 orders-of-magnitude higher than any of the other scenarios. This is because the farm family intruder scenario has the most exposure routes and exposure time of all the scenarios. In fact, for the 30-year exposure duration, the farm family intruder scenario health impacts for all sites are estimated to be highest possible (i.e., risk of 1.0E+00). The health impacts between $\mathrm{CH}$ and RH TRU waste are generally equivalent, although there are less sites that contain RH TRU waste. The SRS has the highest estimated health impacts for the CH. TRU waste for the driller scenario (9.0E-05 LCFs) as well as for the gardener intruder scenarios (6.3E-02 LCFs over 30 years with a maximum annual impact in year 1 of 4.4E-03); the RFETS has the highest estimated health impacts for the $\mathrm{CH}$ TRU waste scavenger (1.9E-02 LCFs) and farm family intruder scenarios (4 LCFs in the first year). For the RH TRU waste, the Hanford Site has the highest estimated health impacts for all scenarios.

For the chemical carcinogens in the driller scenario, at all sites, the cancer incidence is at least 4 orders-of-magnitude below the 1.0E-06 limit generally used to indicate a level of concern. Chemical noncarcinogens in the $\mathrm{CH}$ driller scenario are in general 2 orders-of-magnitude below the permissible exposure limits allowed in short-term occupational settings. However, in the RH waste, lead is 3 times the permissible exposure limit at all sites. For the gardener intruder scenario, the cancer incidence values for beryllium and cadmium are estimated $(5.1 \mathrm{E}-01$ and $5.5 \mathrm{E}-03$, respectively) to be above the 1.0E-06 limit generally used to indicate a level of concern. For the chemical noncarcinogens, only lead is estimated (1.1E-01) to approach the reference level of $1.0 \mathrm{E}+00$. In general, the hazardous chemical impacts from the intruder scenarios are not estimated to be significant from the TRU waste at the 7 sites evaluated.

From the long-term analysis, the estimated maximum lifetime latent cancer fatality to the maximally exposed individual over the 10,000-year analysis period from environmental release of radioactive contaminants associated with buried and surface-stored TRU waste ranged from 7.5E-07 to 1.3E-02 over the 7 sites. The highest lifetime latent cancer fatality was estimated to occur within the first 70 years after loss of institutional control at the Hanford Site. The dominant exposure pathway was the air inhalation pathway and key radioactive contaminants were americium-241 and plutonium-238.

The estimated maximum lifetime latent cancer fatality to the surrounding population from the air and/or surfacewater exposure pathways over the 10,000-year analysis period from environmental release of radioactive contaminants associated with buried and surface-stored TRU waste ranged from 3.2E-04 to $2.1 \mathrm{E}+01$ over the 7 sites. The highest lifetime latent cancer fatality to population was estimated to occur around 700 years after loss of institutional control at the Rocky Flats Environmental Technology Site. The dominant exposure pathway was the air inhalation pathway and key radioactive contaminants were plutonium-239, plutonium-240, and americium-241. The accumulative impact from 
all 7 sites over the 10,000-year postclosure period (i.e., 143 generations) was estimated to result in 2,325 latent cancer fatalities within a population size of 1,560,912,782 (sum of the atmospheric and surfacewater populations from all 7 sites multiplied by 143 generations).

The estimated maximum lifetime cancer incidence to the maximally exposed individual over the 10,000-year analysis period from environmental release of nonradioactive carcinogenic contaminants associated with buried and surface-stored TRU waste ranged from 2.5E-07 to 5.4E-03 over the 7 sites. The highest lifetime cancer incidence was estimated to occur over 3,100 years after loss of institutional control at the Idaho National Engineering Laboratory. The dominant exposure pathway is estimated to be groundwater ingestion and key nonradioactive carcinogenic contaminant is $1,1,2,2-$ tetrachloroethane.

The estimated maximum lifetime cancer incidence to the surrounding population from the air and/or surfacewater exposure pathways over the 10,000-year analysis period from environmental release of nonradioactive carcinogenic contaminants associated with buried and surface-stored TRU waste ranged from $4.2 \mathrm{E}-09$ to $7.4 \mathrm{E}-04$ over the 7 sites. The highest cancer incidence to population was estimated to occur around 500 years after loss of institutional control at the Rocky Flats Environmental Technology Site. The dominant exposure pathway was the air inhalation pathway and key nonradioactive carcinogenic contaminant was 1,1,2,2-tetrachloroethane. The accumulative impact from all 7 sites over the 10,000-year postclosure period (i.e., 143 generations) was estimated to result in 0.25 cancer incidences within a population size of $1,560,912,782$ (sum of the atmospheric and surfacewater populations from all 7 sites multiplied by 143 generations).

The estimated maximum lifetime hazard index to the maximally exposed individual over the 10,000-year analysis period from environmental release of nonradioactive noncarcinogenic contaminants associated with buried and surface-stored TRU waste ranged from $1.5 \mathrm{E}-04$ to $3.2 \mathrm{E}+00$ over the 7 sites. The highest lifetime hazard index was estimated to occur about 700 years after loss of . institutional control at the Savannah River Site. The dominant exposure pathway was groundwater ingestion and the key nonradioactive noncarcinogenic contaminant is mercury. 


\section{Contents}

Summary $\ldots \ldots \ldots \ldots \ldots \ldots \ldots \ldots \ldots \ldots \ldots \ldots \ldots \ldots \ldots \ldots \ldots$ iii

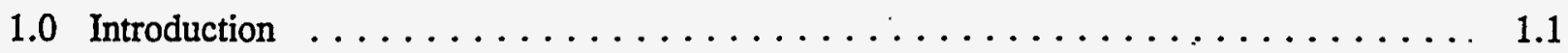

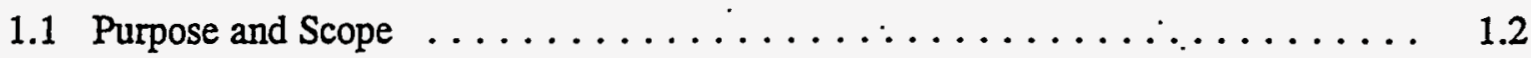

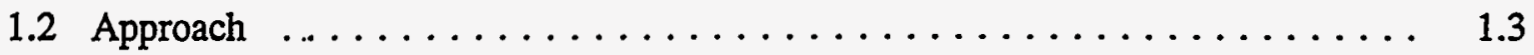

1.3 Report Organization . . . . . . . . . . . . . . . . . 1.4

2.0 Risk Analysis Methodology $\ldots \ldots \ldots \ldots \ldots \ldots \ldots \ldots \ldots \ldots \ldots \ldots \ldots \ldots \ldots \ldots \ldots$

2.1 Risk from Inadvertent Human Intrusion $\ldots \ldots \ldots \ldots \ldots \ldots \ldots \ldots \ldots$

2.1.1 Driller/Gardener Intruder Scenario $\ldots \ldots \ldots \ldots \ldots \ldots \ldots \ldots \ldots$

2.1.2 Scavenger Intruder Scenario $\ldots \ldots \ldots \ldots \ldots \ldots \ldots \ldots \ldots \ldots \ldots$

2.1.3 Farm Family Intruder Scenario $\ldots \ldots \ldots \ldots \ldots \ldots \ldots \ldots . \ldots \ldots$

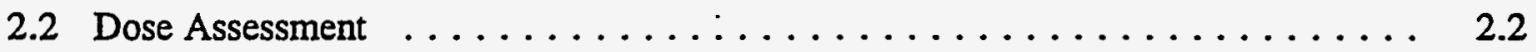

2.3 Risk from Long-Term Chronic Environmental Releases $\ldots \ldots \ldots \ldots \ldots \ldots$

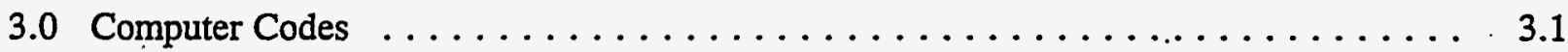

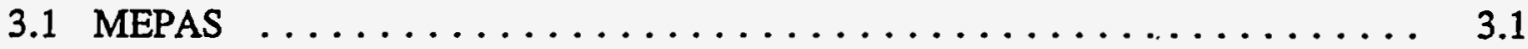

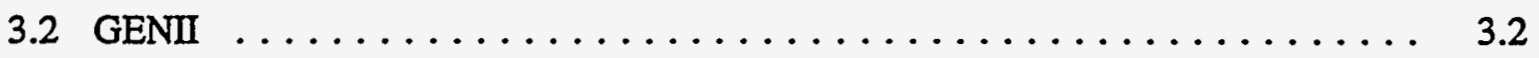

4.0 Description Of Generator/Storage Sites $\ldots \ldots \ldots \ldots \ldots \ldots \ldots \ldots \ldots \ldots$

4.1 Hanford Site $\ldots \ldots \ldots \ldots \ldots \ldots \ldots \ldots \ldots \ldots \ldots \ldots \ldots \ldots \ldots$

4.1.1 TRU Waste Storage $\ldots \ldots \ldots \ldots \ldots \ldots \ldots \ldots \ldots \ldots \ldots . \ldots \ldots$

4.1.2 Local Environmental Settings $\ldots \ldots \ldots \ldots \ldots \ldots \ldots \ldots \ldots \ldots . \ldots \ldots$

4.2 Idaho National Engineering Laboratory $\ldots \ldots \ldots \ldots \ldots \ldots \ldots \ldots \ldots$

4.2.1 TRU Waste Storage $\ldots \ldots \ldots \ldots \ldots \ldots \ldots \ldots \ldots \ldots \ldots \ldots$

4.2.2 Local Environmental Setting $\ldots \ldots \ldots \ldots \ldots \ldots \ldots \ldots \ldots$

vii 
4.3 . Lawrence Livermore National Laboratory $\ldots . \ldots \ldots \ldots \ldots$

$4.3 .1 \cdot$ TRU Waste Storage $\ldots \ldots \ldots \ldots \ldots \ldots \ldots \ldots \ldots \ldots$

4.3.2 Local Environmental Setting $\ldots \ldots \ldots \ldots \ldots \ldots \ldots \ldots \ldots \ldots \ldots \ldots$

4.4 Los Alamos National Laboratory $\ldots \ldots \ldots \ldots \ldots \ldots \ldots \ldots \ldots \ldots \ldots$

4.4.1 TRU Waste Storage $\ldots \ldots \ldots \ldots \ldots \ldots \ldots \ldots \ldots \ldots \ldots \ldots . \ldots \ldots$

4.4 .2 Local Environmental Setting $\ldots \ldots \ldots \ldots \ldots \ldots \ldots \ldots \ldots . \ldots \ldots$

4.5 Oak Ridge National Laboratory $\ldots \ldots \ldots \ldots \ldots \ldots \ldots \ldots \ldots \ldots \ldots$

4.5.1 TRU Waste Storage $\ldots \ldots \ldots \ldots \ldots \ldots \ldots \ldots \ldots \ldots \ldots . \ldots \ldots$

4.5.2 Local Environmental Setting $\quad \ldots \ldots \ldots \ldots \ldots \ldots \ldots \ldots \ldots . \ldots \ldots$

4.6 Rocky Flats Environmental Technology Site $\ldots \ldots \ldots \ldots \ldots \ldots$. . . . . 4.20

4.6.1 TRU Waste Storage $\ldots \ldots \ldots \ldots \ldots \ldots \ldots \ldots \ldots \ldots \ldots . \ldots \ldots$

4.6 .2 Local Environmental Setting $\ldots \ldots \ldots \ldots \ldots \ldots \ldots \ldots . \ldots \ldots$

4.7 Savannah River Site $\ldots \ldots \ldots \ldots \ldots \ldots \ldots \ldots \ldots \ldots \ldots \ldots \ldots \ldots$

4.7.1 TRU Waste Storage $\ldots \ldots \ldots \ldots \ldots \ldots \ldots \ldots \ldots \ldots \ldots \ldots . \ldots \ldots$

4.7.2 Local Environmental Storage $\ldots \ldots \ldots \ldots \ldots \ldots \ldots \ldots \ldots \ldots . \ldots \ldots$

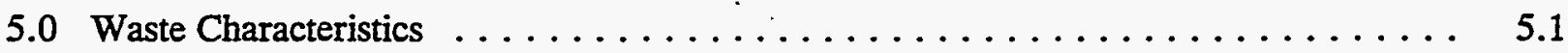

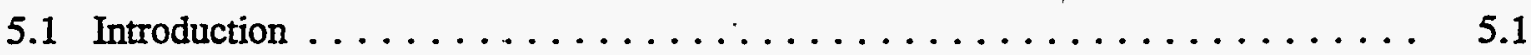

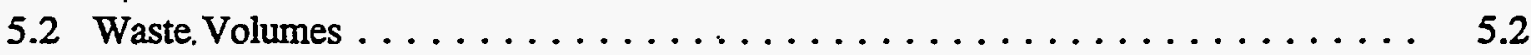

5.3 Contaminant Inventories $\ldots \ldots \ldots \ldots \ldots \ldots \ldots \ldots \ldots \ldots \ldots \ldots \ldots \ldots$

5.3 .1 Radionuclides $\ldots \ldots \ldots \ldots \ldots \ldots \ldots \ldots \ldots \ldots \ldots \ldots \ldots$

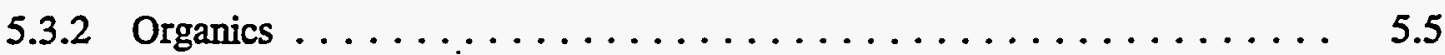

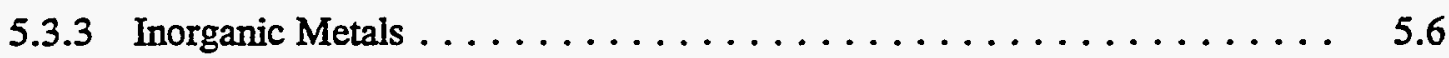

5.4 Description of TRU Waste Forms and TRU Waste-Form Categories . . . . . . 5.6

5.5 Quantity of Each TRU Waste-Form Category $\ldots \ldots \ldots \ldots \ldots \ldots \ldots \ldots$ 
5.6 Contaminant Inventory Distribution over Different TRU.Waste-Form

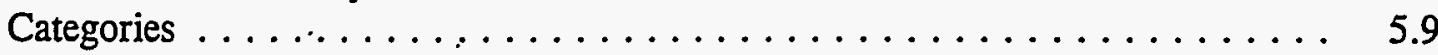

6.0 Waste Configuration and Contaminant-Release Scenarios $\ldots \ldots \ldots \ldots \ldots \ldots .6 .1$

6.1 Conceptual Model for Contaminant Release Scenarios $\ldots \ldots \ldots \ldots \ldots \ldots .6 .1$

6.1 .1 Waste-Storage Configuration $\ldots \ldots \ldots \ldots \ldots \ldots \ldots \ldots \ldots .6 \ldots \ldots$

6.1.2 Assumed Degradation $\ldots \ldots \ldots \ldots \ldots \ldots \ldots \ldots \ldots \ldots .6 .3$

6.1.3 Distribution of TRU Waste Forms $\ldots \ldots \ldots \ldots \ldots \ldots \ldots \ldots .6$

6.2 Contaminant-Release Scenarios $\ldots \ldots \ldots \ldots \ldots \ldots \ldots \ldots \ldots \ldots .6 \ldots \ldots \ldots$

6.2 .1 Soil/Debris TRU Waste Form $\ldots \ldots \ldots \ldots \ldots \ldots \ldots \ldots \ldots \ldots$

6.2.2 Cemented Waste Forms $\ldots \ldots \ldots \ldots \ldots \ldots \ldots \ldots \ldots .6 .8 \ldots \ldots \ldots$

6.2.3 Geochemical Controls on Waste-Form Leaching $\ldots \ldots \ldots \ldots \ldots .6$

6.3 Contaminants of Concern $\ldots \ldots \ldots \ldots \ldots \ldots \ldots \ldots \ldots \ldots \ldots .6 \ldots \ldots \ldots$

6.3.1 Radioactive Contaminant-Screening Analysis $\ldots \ldots \ldots \ldots \ldots \ldots .6 .9$

6.3.2 Inorganic Contaminant-Screening Analysis $\ldots \ldots \ldots \ldots \ldots \ldots \ldots .6 .11$

6.3.3 Organic Contaminant-Screening Analysis $\ldots \ldots \ldots \ldots \ldots \ldots \ldots .6 .11$

6.3.4 Key Contaminants Evaluated in No Action Alternative $2 \ldots \ldots \ldots \ldots .6 .12$

6.4 Example Contaminant-Release Calculations $\ldots \ldots \ldots \ldots \ldots \ldots \ldots \ldots .6 .12$

7.0 Airborne And Waterborne Transport $\ldots \ldots \ldots \ldots \ldots \ldots \ldots \ldots \ldots \ldots \ldots . .1$

7.1 Airborne-Transport Parameters $\ldots \ldots \ldots \ldots \ldots \ldots \ldots \ldots \ldots \ldots \ldots .7 .1$

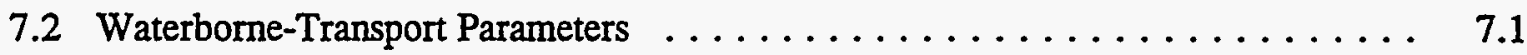

7.3 Calculated Soil-Erosion Rates for Each Site $\ldots \ldots \ldots \ldots \ldots \ldots \ldots \ldots .7 .1$

7.4. Air- and Water-Receptor Locations $\ldots \ldots \ldots \ldots \ldots \ldots \ldots \ldots \ldots \ldots .2$

7.5 Unit-Transport Factors $\ldots \ldots \ldots \ldots \ldots \ldots \ldots \ldots \ldots \ldots \ldots \ldots .2$ 
8.0 Calculation of Unit Exposure and Unit Impact Factors $\ldots \ldots \ldots \ldots \ldots \ldots$

8.1 Background Information and Scope of Analyses $\ldots \ldots \ldots \ldots \ldots \ldots \ldots$

8.2 Individual UDF and UIF Calculations $\ldots \ldots \ldots \ldots \ldots \ldots \ldots \ldots \ldots \ldots$

8.3 Population UDF and UIF Calculations $\ldots \ldots \ldots \ldots \ldots \ldots \ldots \ldots \ldots$

9.0 Summary of Long-Term Impacts of No Action Alternative $2 \ldots \ldots \ldots \ldots$

9.1 Impacts from Intrusion into Wastes $\ldots \ldots \ldots \ldots \ldots \ldots \ldots \ldots . \ldots \ldots$

9.1 .1 Buried Waste Storage $\ldots \ldots \ldots \ldots \ldots \ldots \ldots \ldots \ldots . \ldots \ldots$

9.1 .2 Surface-Stored Wastes $\ldots \ldots \ldots \ldots \ldots \ldots \ldots \ldots \ldots \ldots \ldots$

9.1.3 Summary of Intruder Scenario Results . . . . . . . . . . . 9.5

9.2 Long-Term Impacts of Environmental Release $\ldots \ldots \ldots \ldots \ldots . \ldots \ldots$

9.2 .1 Radiological Impacts $\ldots \ldots \ldots \ldots \ldots \ldots \ldots \ldots \ldots \ldots \ldots . \ldots \ldots$

9.2.2 Chemical Carcinogen Impacts $\ldots \ldots \ldots \ldots \ldots \ldots \ldots \ldots \ldots$

9.2.3 Noncarcinogen Impacts $\ldots \ldots \ldots \ldots \ldots \ldots \ldots \ldots$

9.2.4 Summary of Long-Term Impacts from Environmental Release . . . . . . . 9.8

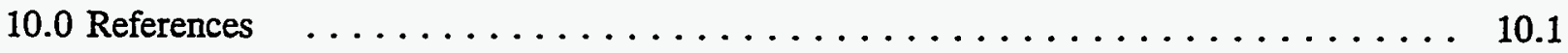

Appendix A - Contaminant Inventory Data . . . . . . . . . . . . . . A.1

Appendix B - Contaminant Property Data . . . . . . . . . . . . . . B.1

Appendix C - Waste Form Data $\ldots \ldots \ldots \ldots \ldots \ldots \ldots \ldots \ldots \ldots \ldots \ldots \ldots \ldots$ 


\section{Figures}

1.1 Location of the 10 Major Generator/Storage Sites $\ldots \ldots \ldots \ldots \ldots$

3.1 Simplified Diagram Outlining Various Linkages of MEPAS $\ldots \ldots \ldots \ldots \ldots \ldots$

4.1 Location and Environmental Settings for the Hanford Site $\ldots \ldots \ldots \ldots . \ldots$

4.2 Stratigraphic Columns for Hanford Site Environmental Settings $\ldots \ldots \ldots \ldots .4$

4.3 Location and Environmental Settings for the Idaho National Engineering Laboratory . . 4.6

4.4 Stratigraphic Columns for Idaho National Engineering Laboratory

Environmental Settings $\ldots \ldots \ldots \ldots \ldots \ldots \ldots \ldots \ldots \ldots \ldots$

4.5 Location and Environmental Settings for the Lawrence Livermore National

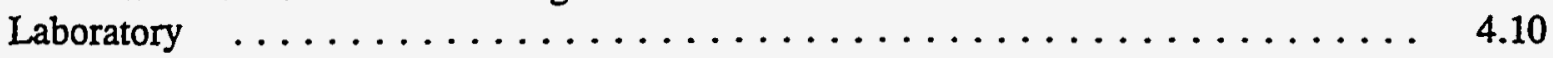

4.6 Stratigraphic Column for Lawrence Livermore National Laboratory

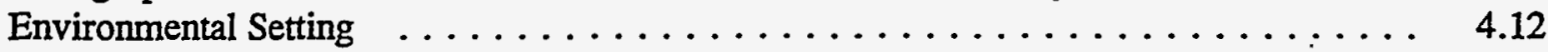

4.7 Location and Environmental Settings for the Los Alamos National Laboratory . . . . 4.13

4.8 Stratigraphic Columns for Los Alamos National Laboratory Environmental Settings . . 4.15

4.9 Location and Environmental Settings for the Oak Ridge Reservation . . . . . . . 4.17

4.10 Stratigraphic Columns for Oak Ridge National Laboratory Environmental Settings . . 4.19

4.11 Location and Environmental Settings for the Rocky Flats Environmental

Technology Site . . . . . . . . . . . . . $\ldots \ldots \ldots \ldots \ldots$

4.12 Stratigraphic Columns for Rocky Flats Environmental Technology Site

Environmental Settings $\ldots \ldots \ldots \ldots \ldots \ldots \ldots \ldots \ldots \ldots \ldots \ldots \ldots \ldots \ldots \ldots \ldots .22$

4.13 Location and Environmental Settings for the Savannah River Site $\ldots \ldots \ldots$. . . . . 4.24

4.14 Stratigraphic Columns for Savannah River Site Environmental Settings $\ldots \ldots \ldots$. . . 4.26

$6: 1$ Overall Configuration of the Buried Waste-Storage Zone $\ldots \ldots \ldots \ldots \ldots . \ldots$

6.2 Overall Configuration of the Surface Waste-Storage Zone $\ldots \ldots \ldots \ldots . \ldots$

6.3 Schematic of the Screening Process for Contaminants of Concern $\ldots \ldots \ldots .9$

6.4 Comparison of Contaminant-Leaching-Flux Curves from Different Waște Forms $\ldots \ldots .6 .13$. 
6.5 Comparison of Contaminant-Leaching-Flux Curces for Desorption and Solubility

9.1 Summary of Site-Specific Radiological Dose for the Maximally Exposed Individual

9.2 Summary of Site-Specific Radiological Dose for Exposed Populations . . . . . . . . 9.10

9.3 Summary of Site-Specific Radiological Latent Cancer Fatalities for the Maximally

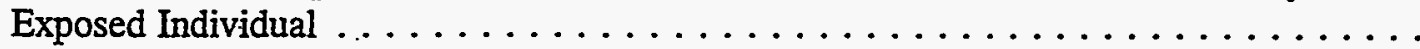

9.4 Summary of Site-Specific Radiological Latent Cancer Fatalities for the Exposed Population

9.5 Summary of Site-Specific Chemical Carcinogenic Cancer Incidence for the Maximally Exposed Individual

9.6 Summary of Site-Specific Chemical Carcinogenic Cancer Incidence for Exposed Populations

9.7 Summary of Site-Specific Chemical Noncarcinogenic for the Maximally Exposed Individual 


\section{Tables}

2.1 No Action Alternative 2 - Scenario Parameters $\ldots \ldots \ldots \ldots \ldots \ldots \ldots$

5.1 TRU Waste Volumes for No Action Alternative $2 \ldots \ldots \ldots \ldots \ldots \ldots \ldots \ldots \ldots$

5.2 Volume Factors Used to Estimate Total $\mathrm{CH}$ TRU Radionuclide Inventories at

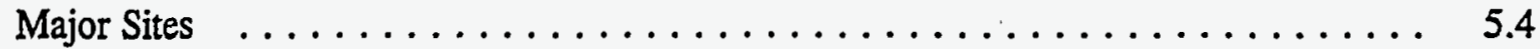

5.3 Volume Factors Used to Estimate Total RH TRU Radionuclides Inventories at

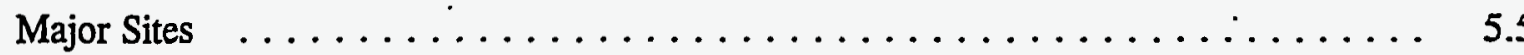

5.4 Final TRU Waste Form Definitions $\ldots \ldots \ldots \ldots \ldots \ldots \ldots \ldots \ldots$

5.5 Relative Quantities and Volumes of Each Waste-Form Category by Release-Site . . . . 5.9

6.1 Overall Waste-Zone Volumes and Horizontal Areas for each. Waste-Form Category by Release Site $\ldots \ldots \ldots \ldots \ldots \ldots \ldots \ldots \ldots \ldots \ldots \ldots \ldots \ldots \ldots \ldots \ldots \ldots$

$6.2^{\circ}$ Contaminants of Concern for the No Action Alternative 2 Analyses $\ldots \ldots \ldots . \ldots$

6.3 Nonzero Contaminant-Flux Factors Produced by Site and Waste-Form Category $\ldots \ldots .6 .13$

7.1 MEPAS-Calculated Water-Infiltration and Soil-Removal Rates for Each Site $\ldots \ldots \ldots 7.2$

8.1 Site Specific Population Data used for No Action Alternative 2 Analysis $\ldots \ldots \ldots . . \quad 8.3$

9.1 Summary of Radiological Impacts for Intruder Scenarios by Site $\ldots \ldots \ldots \ldots \ldots$

9.2 Summary of Hazardous Contaminants for the Driller and Gardener Intruder Scenarios . . $\quad 9.4$

9.3 Summary of Radioactive Impacts to the Maximally Exposed Individual and Population after Loss of Institutional Control at the Seven Major Generator/Storage Sites . . . . . 9.6

9.4 Summary of Nonradioactive Carcinogen Impacts to the Maximally Exposed Individual and Population after Loss of Institutional Control at the Seven Major Generator/

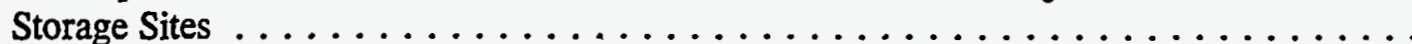

9.5 Summary of Noncarcinogen Impacts to the Maximally Exposed Individual after Loss of Institutional Control at the Seven Major Generator/Storage Sites 
A.1 Composition of Soil-Pore Waters Used for Solubility Modeling $\ldots \ldots \ldots$. . . . A.4

A.2 Calculated Solubilities Used for No Action Alternative $2 \ldots \ldots \ldots \ldots \ldots \ldots$

A.3 $\mathrm{K}_{\mathrm{d}}$ Values Used in No Action Alternative 2 Analyses $\ldots \ldots \ldots \ldots \ldots \ldots \ldots$. . . . . . .

A.4 Grout-Diffusion Coefficient Used for No Action Alternative 2 Analyses $\ldots \ldots \ldots$. . . A.17 


\subsection{Introduction}

The U.S. Department of Energy (DOE) needs to dispose of transuranic (TRU) wastes generated by past, present, and future activities in a manner that protects human health and the environment. TRU wastes have been generated since the 1940s as part of the nuclear defense research and production activities of the Federal Government. Until about 1970, TRU waste, then classified as low-level wastes (LLW), was disposed in shallow trenches without any intent to retrieve it. In 1970, it was determined that TRU wastes should be isolated and disposed of in a manner different than LLW. At that time, the U.S. Atomic Energy Commission, predecessor to the DOE, adopted a policy requiring that wastes containing TRU elements be placed in containers that could be retrieved from storage within $20 \mathrm{yr}$. Currently, $\sim 6,200,000 \mathrm{~m}^{3}$ of contact-handled (CH) TRU and 3,600 $\mathrm{m}^{3}$ of remote-handled (RH) TRU wastes are in retrievable storage configurations at $\sim 20$ sites around the United States.

In previous National Environmental Policy Act of 1969 (NEPA) documents prepared since the late 1970s, DOE examined the impacts of a number of alternatives that involve disposal of TRU wastes in a deep geologic repository in bedded saltbeds at the Waste Isolation Pilot Plant (WIPP), located $-50 \mathrm{~km}$ east of Carlsbad, New Mexico. Two major documents were completed by DOE in 1980 and 1990 to meet NEPA requirements for such a disposal action. In 1980, DOE prepared the Final Environmental Impact Statement for the Waste Isolation Pilot Plant (FEIS) to assess the potential impacts of developing WIPP and alternatives for disposing of managed defense TRU wastes. By 1990, following construction of WIPP facilities, DOE decided to prepare the Final Supplement Environmental Impact Statement for the Waste Isolation Pilot Plant (SEIS-I) to update the environmental record established in the FEIS. In 1996, the DOE Carlsbad Area Office, with assistance from Pacific Northwest National Laboratory(a) (PNNL) and Battelle Memorial Institute, is preparing a Draft Waste Isolation Pilot Plant Disposal Supplemental Environmental Impact Statement (SEIS-II) to meet the commitment DOE made in the Record of Decision associated with SEIS-I to move forward with the disposal of TRU. SEIS-II is also being prepared to take into account the regulatory, statutory, the TRU waste inventory, and waste-acceptance criteria changes that have been developed since the SEIS-I analysis was completed. SEIS-II will atso take into account new hydrologic and geologic information collected and interpreted since 1990, which may affect the long-term performance of the WIPP disposal facility.

Among the six alternatives being considered for analysis in SEIS-II is an alternative referred to as No Action Alternative 2. Under this alternative, no TRU wastes would be shipped to WIPP. Current TRU. waste-management practices would continue at all sites, except where DOE has entered into agreements to have waste removed from small-quantity sites to facilitate safe long-term storage. In such cases, it is assumed that TRU wastes from small-quantity sites would be shipped to 10 larger consolidation sites. For purposes of this analysis, these sites were assumed to include the Hanford Site (Hanford), the Idaho National Engineering Laboratory (INEL), the Lawrence Livermore National

(a) The Pacific Northwest National Laboratory is operated by Battelle for the U.S. Department of Energy. 
Laboratory (LLNL), the Los Alamos National Laboratory (LANL), the Oak Ridge National Laboratory (ORNL), the Rocky Flats Environmental Technology Site (RFETS), the Savannah River Site (SRS), Argonne National Laboratory (ANL), the Mound Site (Mound), and the Nevada Test Site (NTS). Existing TRU waste in storage would not be treated to WIPP waste-acceptance criteria; however, newly generated TRU wastes would be treated to meet WIPP waste-acceptance criteria. Based on these assumptions, No Action Alternative 2 analyzes the environmental and human-health impacts of longterm storage of TRU at major generator/storage sites across the country. This is done by estimating the potential impacts of TRU waste stored at these sites after loss of institutional control.

\subsection{Purpose and Scope}

The purpose and scope of this analysis are to perform long-term environmental consequence analyses for radionuclides and hazardous materials to address No Action Alternative 2 after loss of institutional control. This alternative addresses the long-term impacts of stored TRU waste after loss of institutional control at 7 of the 10 major generator/storage sites.

Under No Action Alternative 2, TRU wastes would not be emplaced at the WIPP during the disposal phase. Therefore, no radiological consequences to workers or the public results from such emplacement. However, exposures would continue to occur at the major generator/storage sites.

In this analysis, the environmental and human-health impacts were estimated at 7 of the 10 major generator/storage sites (Figure 1.1): Hanford, INEL, LANL, LLNL, ORNL, RFETS, and SRS. The analysis focused on these 7 major sites because $99 \%$ of the estimated TRU waste volume and inventory will be generated/stored there. Other sites considered but not examined in this analysis include ANL, Mound, and NTS.

In the FEIS (DOE 1980) and SEIS-I (DOE 1990) analyses of the no action alternatives, no longterm environmental consequence analysis was performed. The principal assumption was that TRU wastes would be in indefinite storage at the 10 major generator/storage sites. Institutional control, with effective monitoring and maintenance of storage facilities, would be sufficient to preclude any site impacts. The impact analysis performed focused on expected site operations associated with treatment and storage.

In previous FEIS and SEIS analyses, DOE referenced completed NEPA documents for some of the major retrievable storage facilities that describe the effects of continued retrievable storage. These sites include Hanford, INEL, and SRS. The reader is referred to the published environmental documents for greater detail (DOE 1980, 1987, 1988).

Under this No Action Alternative 2, TRU wastes are assumed to be generated at all sites, including small generator sites, over a 35-yr period. During this period, wastes generated at small-quantity sites will be consolidated and treated at the 10 major generator/storage sites. As it is consolidated and/or generated at the 10 major sites, the wastes will be put into retrievable storage consistent with current practices. Current storage configurations include storage in soil-covered asphalt or concrete pads, 


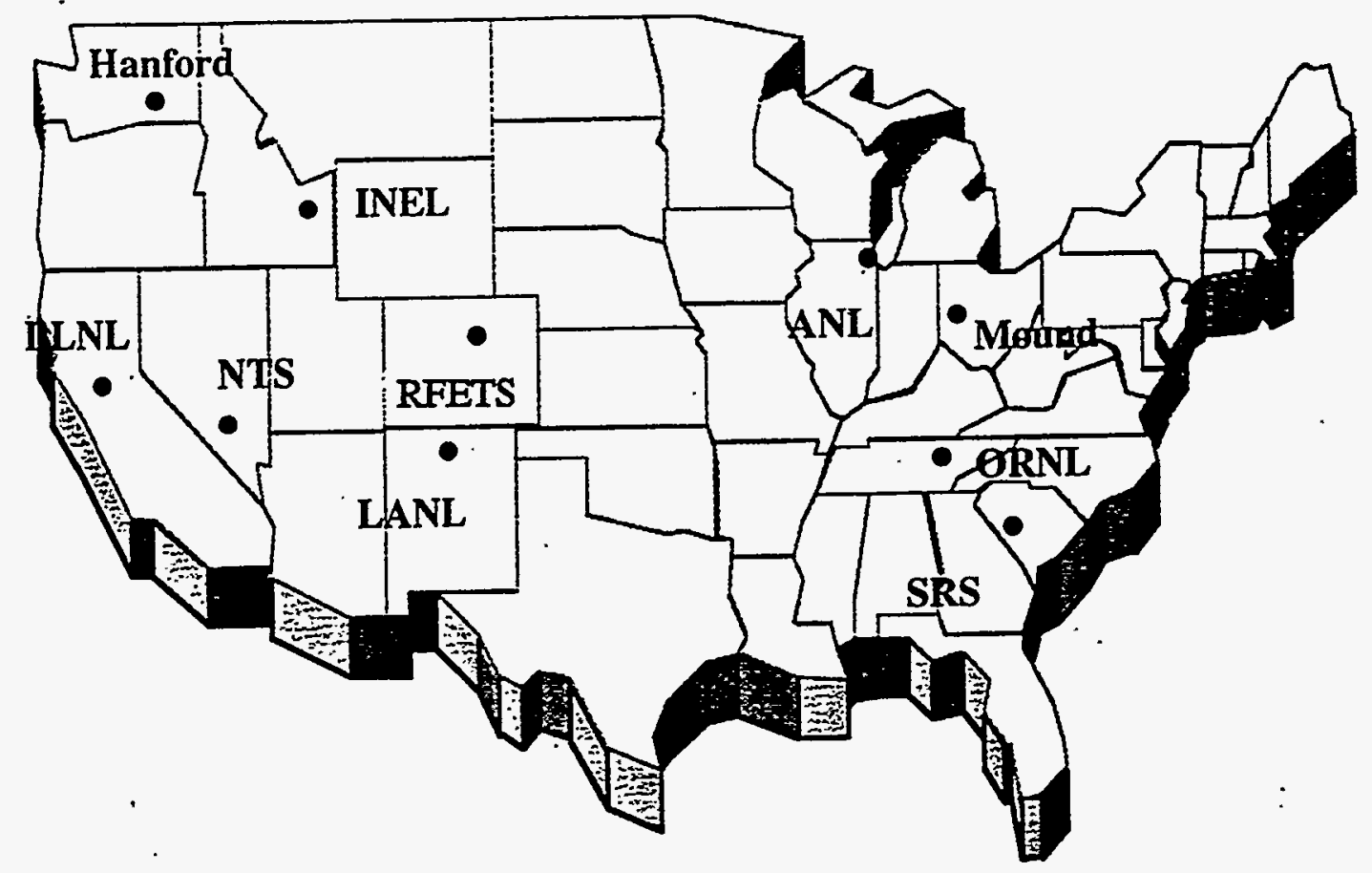

Figure 1.1 Location of the 10 Major Generator/Storage Sites

shallow trenches, aboveground earthen berms, covered enclosures, storage buildings, and buried caissons ( $\mathrm{RH}$ waste only). The waste would remain in the assumed storage configurations for a 100-yr period of institutional control. The 100-yr period of institutional control includes at its beginning a 10-yr period of decommissioning of waste-handling and -treatment facilities. During this period, effective monitoring, surveillance, and maintenance of storage facilities will be sufficient to maintain the release of contaminants from these storage facilities to a minimum.

At the end of this 100-yr period, institutional control is assumed to be lost, and stored waste and associated facilities begin to degrade, allowing waste to be released and become mobile in the accessible environment. Calculations of the long-term consequences of environmental releases from these storage facilities were performed for 10,000 years after loss of control. No environmental and/or human-health calculations resulting from storage-facility releases were evaluated during the institutional control period.

\subsection{Approach}

The general approach uses, to the extent possible, environmental data sets, methods, and models established for the consequence analysis of low-level waste and low-level mixed waste developed for the Waste Management Programmatic and Environmental Impact Statement for Managing Treatment, Storage, and Disposal of Radioactive and Hazardous Wastes (WM PEIS) (DOE 1995a). These data 
sets, methods, and models were modified and changed as appropriate for assumed TRU inventories, storage-site locations, and related environmental transport parameters. Sources for the analysis include site descriptions and data provided in the following:

- draft WM PEIS (DOE 1995a)

- referenced contractor reports supporting the WM PEIS analysis (Holdren et al. 1995; Bergenback et al. 1995; Blaylock et al. 1995)

- key site-specific environmental references

- Baseline Inventory Report (DOE 1995b).

\subsection{Report Organization}

This report, providing supplemental information to SEIS II, describes the underlying bases, data, and assumptions used to estimate the impacts from postulated long-term releases of radionuclides and hazardous constituents from TRU wastes stored at major generator/storage sites after loss of institutional control for No Action Alternative 2. Chapter 2.0 outlines the risk analysis methodology, including the three intrusion scenarios and underlying equations to determine the long-term chronic environmental releases. Chapter 3.0 gives a brief discussion of the computer codes used. Chapter 4.0 describes each of the 7 major generator/storage sites by their regional setting, waste-storage facilities, and environmental setting. Chapter 5.0 describes the waste volumes, waste types, and contaminant inventories found at each of the 7 sites under consideration. Chapter 6.0 outlines the waste configuration and release scenarios for the contaminants of concern. Chapter 7.0 discusses the parameters dealing with airborne and waterborne transport. The calculations of unit exposure and unit impact factors are given in Chapter 8.0, followed by the summary of results in Chapter 9.0. Chapter 10.0.is a listing of the references cited in the text. A set of appendices are provided in this report. Appendix A provides detailed information on contaminant inventories, Appendix B provides detailed information on contaminant properties and associated data values, Appendix $C$ provides waste form categories and descriptions, and Appendix D provides tabular data on the four intruder scenarios evaluated. 


\subsection{Risk Analysis Methodology}

The human-health impacts resulting from exposure to TRU wastes were estimated for 1) exposure from inadvertent human intrusion into areas of TRU waste storage and 2) long-term exposure from source-term releases to surface and subsurface environmental exposure points.

Consistent risk measures were used to facilitate the comparison of the disposal alternatives. For radioactive substances, doses were estimated for the maximally exposed individual (MED) and exposed populations for the 70-yr period (lifetime) of highest dose and then expressed in terms of latent cancer fatalities (LCFs). For chemical carcinogens, excess cancer incidence was calculated to the MEI and to the exposed population for the 70-yr period of highest exposure. For noncarcinogenic. chemical substances, the maximum hazard index for the MEI for the highest period of exposure was estimated.

Following are descriptions of the approaches used for the human-intrusion and long-term environmental release scenarios used in this analysis.

\subsection{Risk from Inadvertent Human Intrusion}

Estimation of risk from human intrusion considered in this analysis included the following scenarios: driller/gardener, scavenger, and farm family.

\subsubsection{Driller/Gardener Intruder Scenario}

Under this scenario, a hypothetical intruder drills a water well directly through buried or soilcovered TRU waste to the groundwater. As a result of the drilling, contaminated soil is brought to the surface and mixes with the topsoil. The intruder is exposed via inhalation of resuspended contamination, external radiation, and inadvertent ingestion of contaminated soil. Exposure occurs while at the site over a 5-d period (one work week) and therefore is considered an acute exposure scenario. The contamination is assumed to be instantaneously mixed into the top $15 \mathrm{~cm}$ of clean surface soil. Further, it was assumed in this scenario that the extent of contamination was limited to an area of 10 by $10 \mathrm{~m}$.

Subsequently, the same individual farms a garden on the land containing the contaminated soil over a period of 30 years. During this time, the intruder will receive $25 \%$ of his yearly vegetable and fruit intake from this garden. The volume of contamination is limited to that of the drill tailings but is . spread out over $2500 \mathrm{~m}^{2}$. In addition to food crops, the individual is further exposed via inhalation of resuspended contamination, external radiation, and inadvertent ingestion of contaminated soil. This scenario is considered chronic exposure because of the 30-yr exposure duration. 


\subsubsection{Scavenger Intruder Scenario}

In this scenario; a hypothetical scavenger comes into direct contact with surface-stored TRU waste over a $24-\mathrm{h}$ period. The scavenger is exposed via inhalation of resuspended contamination, external radiation, and inadvertent ingestion of contaminated soil while at the site. The scavenger does not ingest any food but is exposed via inhalation of resuspended soil (waste) and via external radiation. It is also assumed that no clean soil covers the waste, so the dose factors per unit concentration are multiplied by the waste-form concentration to get the total dose to the scavenger. This scenario is considered to be an acute exposure scenario because of the 24-h exposure period.

\subsubsection{Farm Family Intruder Scenario}

For this scenario, a hypothetical farm family of two adults and two children lives and farms on land immediately over what was once the surface-stored TRU waste-disposal area for a $30-y \mathrm{r}$ period. The MEI in the family is exposed via ingestion of contaminated food crops, inhalation of resuspended contamination, external radiation, and inadvertent ingestion of contaminated soil. This scenario is considered a chronic exposure scenario.

\subsection{Dose Assessment}

To assess the dose and risk from these human intrusions, a unit methodology was employed. To bound the impact, it was assumed that all intrusions occur at the moment institutional control is lost. For each location, unit concentrations of contaminants in soil were modeled using the GENII computer code (Napier et al. 1988). These concentrations were then multiplied by the expected concentration of relocated waste in the top $15 \mathrm{~cm}$ of soil. Doses from all radionuclides of concern were summed to yield the total effective dose equivalent for each receptor. Calculated doses were then converted to appropriate LCFs, using methods described in Chapter 3.0.

The GENII calculations assumed that the driller intruder was exposed via external ground radiation for $40-\mathrm{h}$, via inhalation of resuspended soil for $1-\mathrm{h}$, and via inadvertent ingestion of soil for 5-d at a rate of $100 \mathrm{mg} / \mathrm{d}$. The soil resuspension is based on an average mass loading factor of $1.0 \mathrm{E}-04 \mathrm{~g}_{\text {soi }} /$ $\mathrm{m}_{\text {air. }}^{3}$ From these input parameters, a dose factor of dose per curie per cubic meter of soil down to $15 \mathrm{~cm}$ below surface was derived.

Calculation of the concentration was based on the initial waste-form concentration times the volume of waste relocated to the top $15 \mathrm{~cm}$ of soil in a $100-\mathrm{m}^{2}$ area. The circular drill hole was assumed to be $30 \mathrm{~cm}$ in diameter and $4 \mathrm{~m}$ in depth. The volume of waste removed by drilling was then instantaneously combined with the clean soil in the top $15 \mathrm{~cm}$ of the soil column. This concentration times the dose per concentration values generated by GENII were able to model an overall dose to the driller intruder. 
For the driller's hazardous chemical component, the air concentration was multiplied by the driller's breathing rate for a total intake. This intake was then compared to the slope factor for carcinogens and to the permissible exposure limits for noncarcinogens. These factors are summarized in National Institute for Occupational Safety and Health (1996). To calculate the air concentration, the waste concentration times the volume of the waste was adjusted by the release fraction (assumed to be 1 in the driller intruder analysis). The release was then assumed to occur uniformly over the $100 \mathrm{~m}^{2}$ and was multiplied by the resuspension rate (the same as above, $1.0 \mathrm{E}-04 \mathrm{~g} / \mathrm{m}^{3}$ ). The driller's breathing rate was assumed to be $20 \mathrm{~m}^{3} / \mathrm{d}$.

The gardener scenario, following the driller scenario and the scavenger scenario, also employed the same methodologies for determining dose except that the exposure times were longer, the area of contamination was larger, and the ingestion was included as a pathway. All factors employed for radiological dose and hazardous chemical exposures and associated risks are provided in Table 2.1.

Table 2.1. No Action Alternative 2 - Scenario Parameters

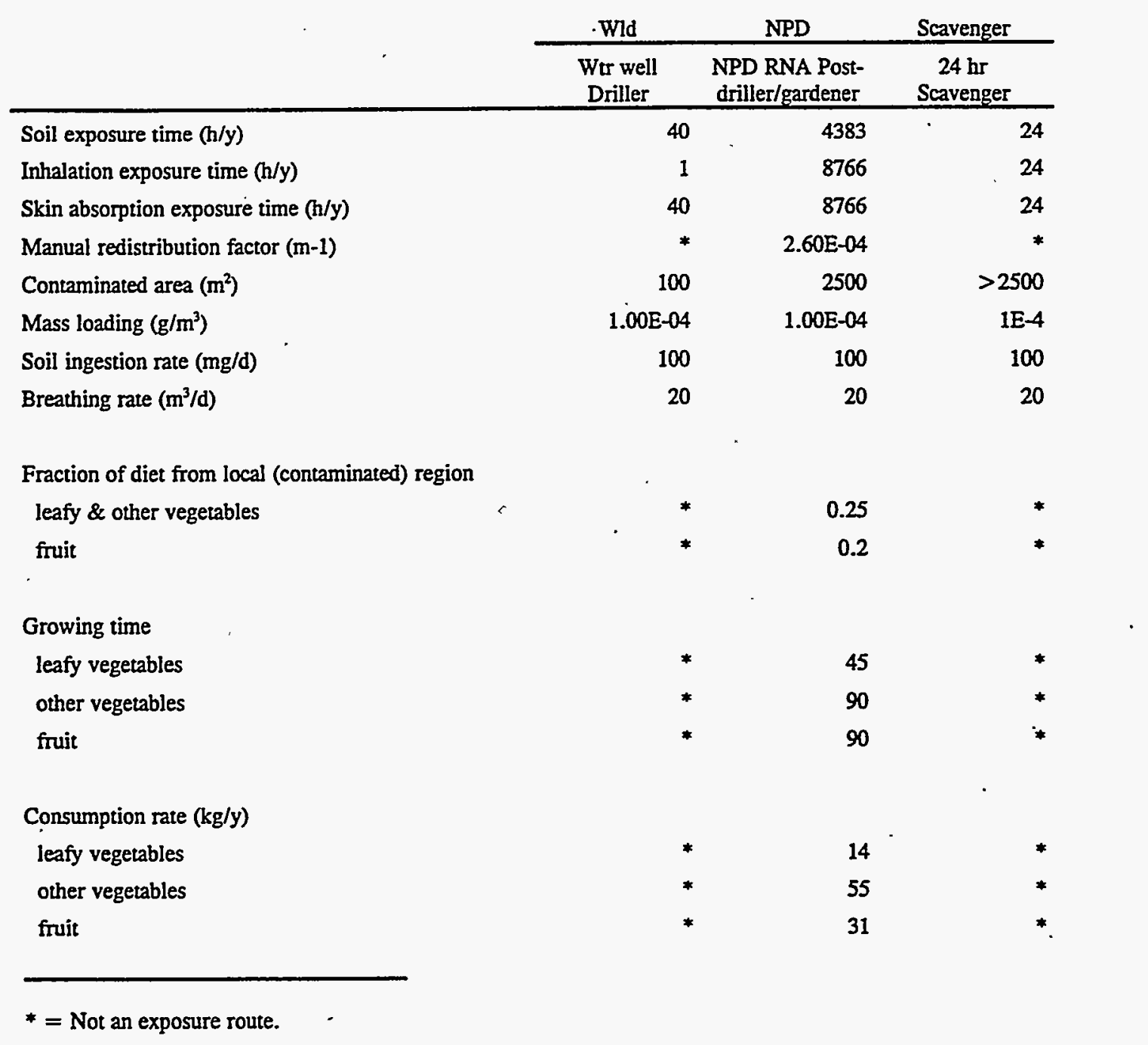




\subsection{Risk from Long-Term Chronic Environmental Releases}

To compare human-health impact estimates from long-term chronic environmental releases of TRU waste at the 7 major generator/storage sites considered under No Action Alternative 2 to those for the WIPP site requires a consistent and efficient approach. To facilitate such an effort, the modular risk assessment (MRA) methodology was used.

The MRA methodology was developed by Pacific Northwest National Laboratory and Advanced Sciences, Inc., to facilitate regional-scale risk analysis. This methodology is described in several documents (e.g., Strenge and Chamberlain 1994; Whelan et al. 1995) and presentations (e.g., Whelan et al. 1994). The MRA methodology was developed for regional and site-wide risk computations involving a large number of release sites and contaminants with different waste forms and for various environmental settings and transport and exposure pathways.

The MRA methodology is based on the assumptions of linearity between the release site source, the environmental transport, and the impacts at the receptor. By determining the linearity of the system, the methodology can be divided into compartments that can be implemented both independently and concurrently. The compartments of the MRA methodology are 1) contaminant mass at the source, 2) determination of contaminant-release rate from the source, 3) transport modeling of the contaminant into the environment (environmental concentrations at the receptor location), 4) exposure assessment for dose to receptor (MEI or population), and 5) estimation of risk at the receptor.

The MRA methodology is based on the following general description for risk/hazard:

$$
\text { Health Impact }=\mathrm{P} \times \mathrm{RF} \times \mathrm{URF}
$$

where Health Impact $=$ estimated probability of adverse effects (carcinogenic risk for radionuclides and chemical carcinogens and hazard quotient for noncarcinogenic constituents) from a contaminant at a receptor.

$P=$ probability of the release event (unitless).

$\mathrm{RF}=$ releaseable fraction of the source (unitless).

$\mathrm{URF}=$ health impact associated with a contaminant at a receptor, based on a unit quantity at the source and has a unit of health impact per source mass. (NOTE: Source mass is often expressed as a source activity for radioactive contaminants.)

Therefore, the URF, is determined as follows:

$$
U R F=[(Q \times U F F) \bullet U T F] \times U D F \times U I F
$$

where $\quad Q=$ estimated mass of contaminant at the source in grams or curies.

UFF $=$ time series of contaminant-release-rate fluxes designated as contaminant mass per time divided by unit contaminant mass. 
UTF = time series of environmental concentrations at a receptor produced from the UFF for groundwater, air, surfacewater, and soil media (expressed as contaminant mass per volume of medium divided by unit contaminant mass per time).

UDF = dose to an organism from a unit concentration for a given exposure pathway. For chemicals, UDF is expressed as contaminant mass per body mass per time divided by unit contaminant mass per volume of contaminant in the environment at the receptor point. For radionuclides, UDF is expressed as contaminant total dose (rem) divided by unit contaminant mass per volume of contaminant in the environment at the receptor point.

$\mathrm{UIF}=$ unit health-impact factor that provides the dose-conversion factor for radionuclides, cancer potency factor for chemical carcinogens, or reference dose for noncarcinogenic contaminants. For radionuclides, UIF is expressed as cancer fatalities divided by unit contaminant total dose. For chemical carcinogens, UIF is expressed as cancer incidence divided by unit contaminant mass per body mass per time. For chemical noncarcinogens, UIF is expressed as hazard quotient divided by unit contaminant mass per body mass per time.

Whereas Equation (2.2) provides a description of the link between the different unit factors involved in computing the URF, Equations (2.3) through (2.6) provide a description of each of the unit factors that were developed to compute URFs. Note that the UFF and UTF are time series and need to be convoluted together. The source, UDF, and UIF are multipliers.

$$
U F F=\frac{F_{s}}{S_{v}}
$$

where $F_{s}=$ contaminant-flux-release rate from the TRU waste form in grams per year or curies per year.

$S_{u}=$ unit source mass in grams or source activity in curies.

The UFF includes the probability of release and the release-factor fraction for a given scenario.

$$
U T F=\frac{C_{f}}{F_{n}}
$$

where $C_{\mathrm{f}}=$ contaminant concentration at the receptor, based on transport through the appropriate medium in grams per cubic meter or curies per cubic meter divided by grams per year or curies per year (air), grams per square meter or curies per square meter divided by grams per year or curies per year (soil), or grams per milliliter or curies per milliliter divided by grams per year or curies per year (water).

$\mathrm{F}_{\mathrm{u}}=$ unit contaminant flux in grams per year or curies per year.

$$
\mathrm{UDF}=\frac{\mathrm{D}_{\mathrm{c}}}{\mathrm{C}_{\mathrm{u}}}
$$


where $\mathrm{D}_{\mathrm{c}}=$ unit dose from the contaminant in grams of contaminant per kilogram of body mass per day or total dose (rem) to a human at the receptor.

$\mathrm{C}_{\mathrm{u}}=$ unit concentration at the receptor in grams per cubic meter or curies per cubic meter divided by grams per year or curies per year (air), grams per square meter or curies per square meter divided by grams per year or curies per year (soil), or grams per milliliter or curies per milliliter divided by grams per year or curies per year (water), based on contaminant transport through the appropriate medium.

$$
\mathrm{UIF}=\frac{\mathrm{R}_{\mathrm{d}}}{\mathrm{D}_{\mathrm{u}}}
$$

where $R_{d}=$ risk associated with a unit dose as risk per gram of contaminant per kilogram of body mass per day or risk per total dose.

$\mathrm{D}_{\mathrm{u}}=$ unit dose to a human in grams of contaminant per kilogram of body mass per day or total dose (rem).

URFs were developed for the different environmental settings of the 7 major generator/storage sites. Environmental șettings were assumed to have homogeneous climatology, hydrology, and geologic characteristics. Therefore, the URF is representative of the risk from a release site within a region, not actual risk. The local climatology, hydrology, and geologic characteristics for this analysis were developed and published in Holdren et al. (1995). The regional climatology (joint-frequency distributions) and population for regional air receptors for the 7 major generator/storage sites are based on Bergenback et al. (1995).

Conceptual site models were developed for each environmental setting associated with a storage site. These conceptual site models define the relationship between the source contaminant at the release sites and the health impacts at the receptors. The important components associated with these relationships are the constituents of interest, waste-source types and forms, release mechanisms, exposure media, and receptor types. For this analysis, the probability of a release or exposure event is assumed to be 1.0. Likewise, it is assumed that sources are in a releaseable form such that the releaseable fraction of the source is equal to 1.0.

Once the waste configuration and TRU waste forms for each environmental setting have been identified, the release mechanisms need to be selected. For this analysis, infiltration of contaminants to groundwater and surfacewater were considered. Suspension, volatilization, and overland-flow-release mechanisms were also considered. The resulting release rate (contaminant flux) for each release mechanism is also dependent on the TRU waste form. In addition, the solubility of each contaminant in the TRU waste form has potential for being an important factor in determining contaminant-release rates. This analysis considered two different TRU waste forms: 1) soil/debris and 2) cement. An analysis of the solubility limits for the primary TRU waste contaminants at each site was conducted (see Appendix). The results were incorporated into the computations of contaminant fluxes. 
The UFFs were generated using a computer model (Streile et al. 1996) to simulate the release of contaminants from a source term. The model directly considers contaminated soil/debris and solidified (cemented) TRU waste forms. The contaminant is removed from the source by simultaneously evaluating degradation or decay, groundwater leaching, atmospheric volatilization, and soil erosion by wind suspension and overland runoff, as appropriate. Because of potential solubility issues associated with the TRU waste forms analyzed, the contaminant mass $(\mathrm{Q})$ was included with the UFF to produce total flux factors. These were subsequently convoluted with the UTFs, thereby resolving the solubility issue.

The UTF represents the environmental fate and transport component of the unit factor methodology. The UTF value is based on $1 \mathrm{~g}$ or $1 \mathrm{Ci}$ of contaminant at the source per year, which, after being transported through a specific environmental medium, ultimately arrives at the receptor exposure point. The receptor exposure point for groundwater analysis is a well $300 \mathrm{~m}$ directly downgradient from the source, assumed centerline of the plume. The atmospheric receptor is located at the point of highest concentration that is at least $100 \mathrm{~m}$ away from but within an $80-\mathrm{km}$ radius of the release point. The UTF is media dependent.

UIF relates the chemical intake or radiation dose to a risk or hazard index, as appropriate, for each contaminant. Both UIF and UDF are defined for intake or exposure routes of inhalation, ingestion, and external radiation.

Three different human-health-impact types were considered in this study: 1) carcinogenic radionuclides, 2) carcinogenic chemicals, and 3) noncarcinogenic chemicals. These impact types are directly related to the three types of UIFs computed for this study.

Finally, both MEI and population endpoints were considered. MEI endpoints influence UDF calculations by defining dose intake factors and UTF calculations by defining the exact location of the receptor. The combination of these factors requires the convolution of time series and straight multiplication. The UFF and UTF are time series at different locations. The UFF is the time series of contaminant-release rate from the source, while the UTF is the time series of contaminant concentration at the receptor point. Equation (2.7) provides the convolution method used to combine the series.

$$
\mathrm{URF}=[\mathrm{Q} \times \mathrm{UFF}] \bullet \mathrm{UTF}(\tau)=\int_{0}^{\tau}[\mathrm{Q} \times \mathrm{UFF}(\mathrm{t})] \times \mathrm{UTF}(\tau-t) \mathrm{dt}
$$

Once the convolution is completed, all the factors can be combined based on Equation (2.2) to provide health risk or hazard quotient impact values.

The units for air UTFs are either 1) grams of contaminant per cubic meter of air divided by gram per year of contaminant at the source or 2) curies of contaminant per cubic meter of air divided by curie per year of contaminant from the source. The units for soil are either 1) grams of contaminant per square meter of soil divided by gram per year of contaminant from the source or 2) curies of contaminant per square meter of soil divided by curie per year of contaminant from the source. The 
units for surfacewater or groundwater are either 1) grams of contaminant per milliliter of water divided by gram per year of contaminant from the source or 2) curies of contaminant divided by milliliter of water curie per year of contaminant from the source.

The UDF involves an average daily intake in grams of contaminant per kilogram of body mass per day for chemicals or a lifetime radiation dose in rem for radionuclides:

The calculations for population risk were computed in two basic media, surfacewater and air. In surfacewater, the MEI risk is multiplied by the population that uses the surfacewater.

For atmospheric transport, the same approach is inappropriate because the distances and directions between individuals can vary greatly. The varying distances imply that the concentration that different individuals are exposed to can also vary greatly. To adjust for the differences in concentration, an effective atmospheric population value is used. The effective atmospheric population in an angular segment is equal to the population in the angular segment times the concentration in the same angular segment divided by the peak concentration. The peak concentration is the concentration used in the MEI calculation. The total effective population is the summation of the effective population for each angular segment. Because dispersion is unique to each contaminant, the effective population was computed for each contaminant. To compute the atmospheric population risk, the effective population is multiplied by the MEI risk. Equation (2.8) shows how the effective atmospheric population is computed.

$$
\operatorname{EAP}_{j}=\sum_{A S}^{i=1} \frac{P_{i} C_{i, j}}{P C_{j}}
$$

where $\mathrm{EAP}_{\mathrm{j}}=$ effective atmospheric population for contaminant $\mathrm{j}$ (number of people)

AS $=$ angular segment (160 based on 16 directions and 10 distances [unitless])

$P_{i}=$ population assigned to angular segment $i$ (number of people)

$C_{i, j}=$ contaminant $j$ atmospheric concentration for angular segment $i$ (grams or curies per cubic meters)

$\mathrm{PC}_{\mathrm{j}}=$ peak contaminant $\mathrm{j}$ atmospheric concentration (grams or curies per cubic meters). 


\subsection{Computer Codes}

The potential health impacts from exposure to radioactive and hazardous material releases were evaluated with two computer codes. The Multimedia Environmental Pollutant Assessment System (MEPAS) code was used to calculate contaminant fluxes from the source, environmental fate and transport to the receptor point, and toxicological impacts and carcinogenic risks from hazardous constituents (Droppo et al. 1989a, 1989b; 1991; Whelan et al. 1987; Strenge and Peterson 1989; Buck et al. 1995; Streile et al. 1996). GENII was used to calculate radiation dose from atmospheric releases and from radioactive material contamination trapped in soil (Napier et al. 1988). A brief discussion of the key components of these codes used in this analysis follows.

\subsection{MEPAS}

The MEPAS code integrates and evaluates contaminant release, transport, and exposure pathways for chemicals and radioactive releases according to their potential human-health impacts. MEPAS is a physics-based approach that couples contaminant release, migration, and fate for environmental media with exposure routes and chronic health consequences for radiological and nonradiological carcinogens and noncarcinogens. Figure 3.1 gives a simplified diagram of how MEPAS works.

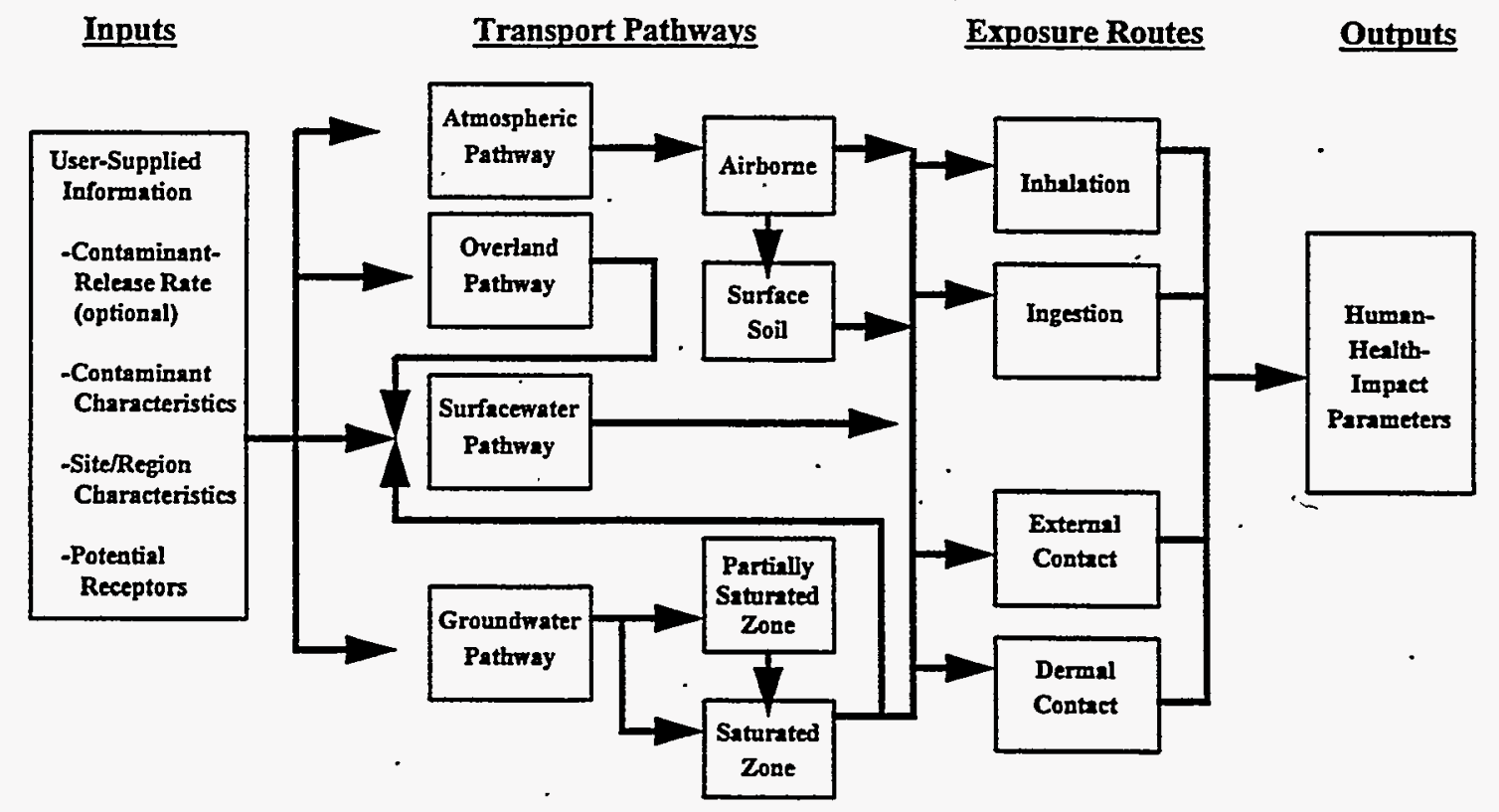

Figure 3.1. Simplified Diagram Outlining Various Linkages of MEPAS 
Contaminant release from the waste zone was modeled by MEPAS source term model (Streile et al. 1996; Buck et al. 1995). In general, the mass or activity of a contaminant in the source zone decreases over time because of contaminant removal by first-order degradation or radioactive decay, leaching to the groundwater, wind suspension, surfacewater erosion, and volatilization.

Hazardous airborne and radioactive and hazardous waterborne contaminant transport in multiple media was evaluated by the MEPAS atmospheric model (Whelan et al. 1987; Droppo et al. 1989a, $1989 \mathrm{~b}, 1991)$. The MEPAS atmospheric model considers the input of suspension and volatilizationrelease rates to compute transport and dilution, washout by cloud droplets and precipitation, and deposition on the underlying surface cover. The atmospheric model uses climatological information on wind speed and direction, precipitation, and atmospheric stability to compute average air and surface contamination concentrations. Contaminant transport is assumed to occur sufficiently fast so that chemical transformation can be neglected.

The MEPAS waterborne transport model (Whelan et al. 1987; Droppo et al. 1989a, 1989b, 1991) consists of two main models: 1) groundwater and 2) surfacewater. These transport models can either be run separately or linked to provide environmental concentrations at specified receptor points. For each waterborne transport pathway, contaminant retardation is described by an equilibrium coefficient, $\mathrm{K}_{\mathrm{d}}$. First-order degradation or decay is assumed for all contaminants that do not result in toxic decay products. On reaching the environmental receptor point, radiological decay is corrected using the Bateman equation, and the model subsequently computes the temporal distribution of each decay progeny.

Results from the different transport pathway models are used as input to the exposure model to calculate the human-health impacts for each contaminant. The following exposure routes are considered to determine the potential exposure of individuals and the surrounding population: 1) dermal contact, 2) external exposure from radionuclides, 3) inhalation, and 4) ingestion. Each exposure route is evaluated to obtain an estimated average daily human exposure from each contaminant. The daily exposure rates are then converted, using mathematical models, to average individual risk factors for radionuclides, carcinogenic chemicals, and noncarcinogenic chemicals.

\subsection{GENII}

The GENII code was used to calculate doses from radioactive material releases to the public. GENII models the environmental transport, contaminant accumulation, and radiation dose to an individual or population, and may be used for acute (less than $24 \mathrm{~h}$ ) or chronic release or exposure scenarios. Atmospheric dispersion is modeled using a straight-line Gaussian-plume model with site-specific meteorological data. Although material deposition is accounted for in determining the exposure from ground-surface deposition of resuspended soil, the GENII code generates conservative plume concentration estimates, in part because the code does not mathematically remove the deposited material from the plume inventory. 
GENII reports the dose impact as the annual committed effective dose equivalent. Dose estimates are based on the integrated dose from internally deposited radionuclides over a period of 50 years and the external dose received during the year of exposure. The dose is translated into a probability of . LCF using the current risk factors in International Commission on Radiation Protection 60 (ICRP 60; 1991). The ICRP 60 estimates the risk of cancer from data based on populations exposed to relatively high doses and dose rates. A dose-reduction factor of 2 is used when doses are below 20 rad, as is the case with all doses estimated in these analyses. The dose-to-risk conversion factors used for estimating cancer deaths from exposure to low dose rates of ionizing radiation are 500 cancer deaths (LCFs) per million person-rem effective dose equivalent (5.0E-04 LCF per person-rem) for the general population and 400 cancer deaths per million person-rem (4.0E-04 LCF per person-rem) for workers. These values include the dose-reduction factor. The difference is attributable to the general population's more diverse age group. For purposes of reporting potential impacts to an individual, dose-risk conversion factors have also been used to estimate the probability of contracting a latent fatal cancer for a representative worker or member of the public.

The ICRP 60 risk factors used are approximately twice the value of the risk factors from Biological Effects of Ionizing Radiation (1980) used in the FEIS, which were the current values at the time. The higher dose-to-risk estimates in ICRP 60 (1991) are the result of improved dose and information provided by the longer followup time for the exposed population studied. 



\subsection{Description of Generator/Storage Sites}

The following are general descriptions of the regional setting, TRU waste-storage facilities, and local environmental setting data and parameters for the 7 major generator/storage sites considered in this analysis.

\subsection{Hanford Site .}

Hanford occupies an area of $\sim 1,450 \mathrm{~km}^{2}$ of arid desert in southeastern Washington State, - $191 \mathrm{~km}$ southwest of the city of Spokane and $240 \mathrm{~km}$ southeast of the city of Seattle (Figure 4.1). Located in Benton, Franklin, and Grant Counties, Hanford is $\sim 50 \mathrm{~km}$ long north to south and $40 \mathrm{~km}$ wide east to west and is located north of the confluence of the Snake and Yakima Rivers with the Columbia River. The Columbia River flows through the northern part of Hanford and turns south, forming part of Hanford's eastern boundary. The Yakima River, along part of the southern boundary, joins the Columbia River below the city of Richland, which bounds Hanford on the southeast. Rattlesnake Mountain, Yakima Ridge, and Umtanum Ridge form the western and southwestern boundaries of Hanford. The Saddle Mountains are located on Hanford's northern boundary. The cities of Richland, Kennewick, and Pasco (commonly referred to as the Tri-Cities) are the nearest population centers (Pacific Northwest Laboratory 1992). The northern border of the city of Richland extends to Hanford's southern border near the 300 Area.

The site is located on the intermontane Columbia Plateau, with topography dominated by basalt plateaus, ridges, and buttes. Major rock units are from oldest to youngest: the Columbia River flood basalts and the Ringold Formation, consisting of unconsolidated fluvial sediments, coarse-grained glacial sediments (referred to as the Hanford formation and also informally referred to as the Pasco gravels).

The uppermost unconfined aquifer at Hanford occurs primarily within sediments of the Hanford and Ringold Formations. The hydraulic conductivity in the Ringold Formation is more than an order of magnitude lower than in the Hanford formation (Thorne and Chamness 1992). Before wastewater disposal began at Hanford, the unconfined aquifer was almost entirely within the less-transmissive Ringold Formation sediments (Thorne and Newcomer 1992). 'However, wastewater-disposal operations in the 200-East and 200-West areas have created groundwater mounds at these locations, and the water table is now in the more-transmissive Hanford formation over much of the eastern portion of the site (Thorne and Newcomer 1992). As a result of the shutdown of Hanford production facilities, the water table is declining. This decline in the water table should continue until new equilibrium conditions are reached (Newcomer et al. 1992). Deeper confined aquifers are found within the Columbia River basalts.

The Columbia River is the only significant surfacewater at Hanford and forms a major discharge point for groundwater at the site. The Hanford Reach is the portion of the river that extends from 


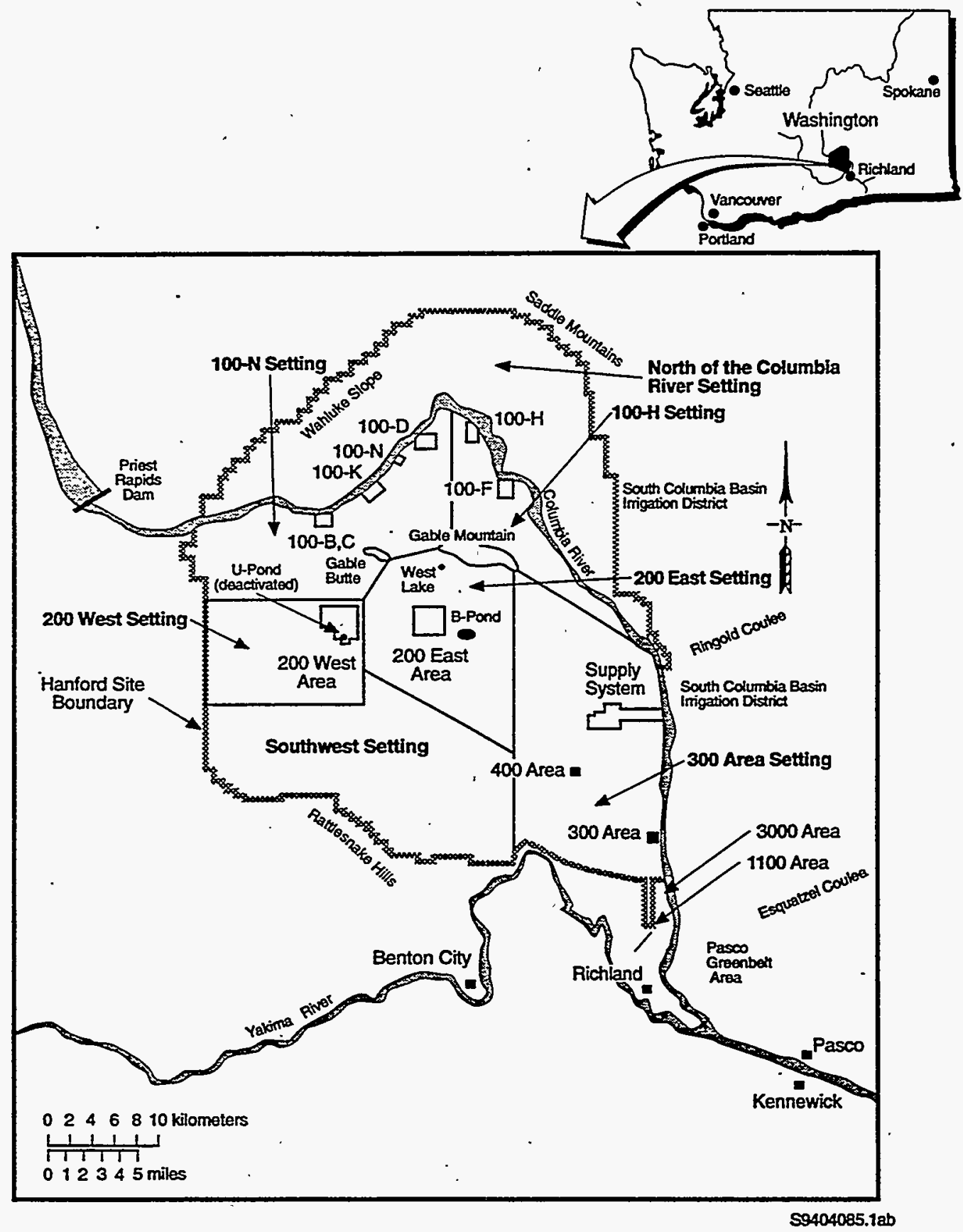

Figure 4.1. Location and Environmental Settings for the Hanford Site (Hanford). For modeling purposes, Hanford is divided into seven environmental settings: North of the Columbia River, 100-N, 100-H, 200-West, 200-East, 300, and Southwest. 
Priest Rapids Dam (upstream of Hanford) to the head of Lake Wallula (downstream of Hanford). Another surfacewater feature in the vicinity of Hanford is the Yakima River. This river approaches Hanford's southwestern boundary and discharges into the Columbia River $-12 \mathrm{~km}$ south.

\subsubsection{TRU Waste Storage}

The TRU wastes generated since 1970 have been retrievably stored within the two operational areas at Hanford (200-East and 200-West). CH wastes are generally stored on asphalt pads in steel drums separated by plywood and plastic-reinforced nylon sheeting and covered with $\sim 1.2 \mathrm{~m}$ of soil to reduce direct radiation exposure. TRU wastes classified as $\mathrm{RH}$ wastes are either stored in caissons or packaged with sufficient shielding to meet requirements for contact handling. Waste unsuitable for asphalt pad or caisson storage because of size, chemical composition, security requirements, or surface radiation have been packaged in reinforced wood, concrete, or metal boxes and stored in dry waste trenches.

\subsubsection{Local Environmental Settings}

For purposes of this analysis, TRU wastes were assumed to be stored in the 200-East and 200-West - areas; two of the seven hydrogeologic environmental settings used to represent Hanford (see Figure 4.1). Figure 4.2 presents stratigraphic columns for each of these settings. Hydrogeologic data for the various settings are presented in Holdren et al. (1995, Tables 5.2 through 5.8). Surfacewater data used are also presented in Holdren et al. (1995, Table 5.1). A brief description of the hydrogeology of the 200-East and 200-West environmental settings are as follows.

The meteorological and atmospheric dispersion data in the form of a joint-frequency distribution of wind direction, wind speed, and atmospheric stability used in this analysis for Hanford are presented in Bergenback et al. (1995).

\subsubsection{200-East Area}

The water table in the 200-East Area is contained within a number of hydrostratigraphic units (Connelly et al. 1992). As a necessary simplification, the water table was placed at the contact between the Hanford coarse-grained facies and the Ringold Formation, which is true for the central and south portions of the 200-East Area. Above the water table, the sediments are divided into three distinct partially saturated zones: 1) upper Pasco gravels, 2) sandy sequence, and 3) lower Pasco gravels. The suggested thicknesses of these units are 10,50 , and $19 \mathrm{~m}$, respectively.

The unconfined aquifer occurs primarily in the Ringold Formation sediments. The thickness of the unconfined aquifer in the 200-East Area has been reported to be up to $38 \mathrm{~m}$; however, the saturated zone thickness was selected to be $9 \mathrm{~m}$, which is the generally accepted thickness of the contaminated portion of the unconfined aquifer in this area of Hanford. 


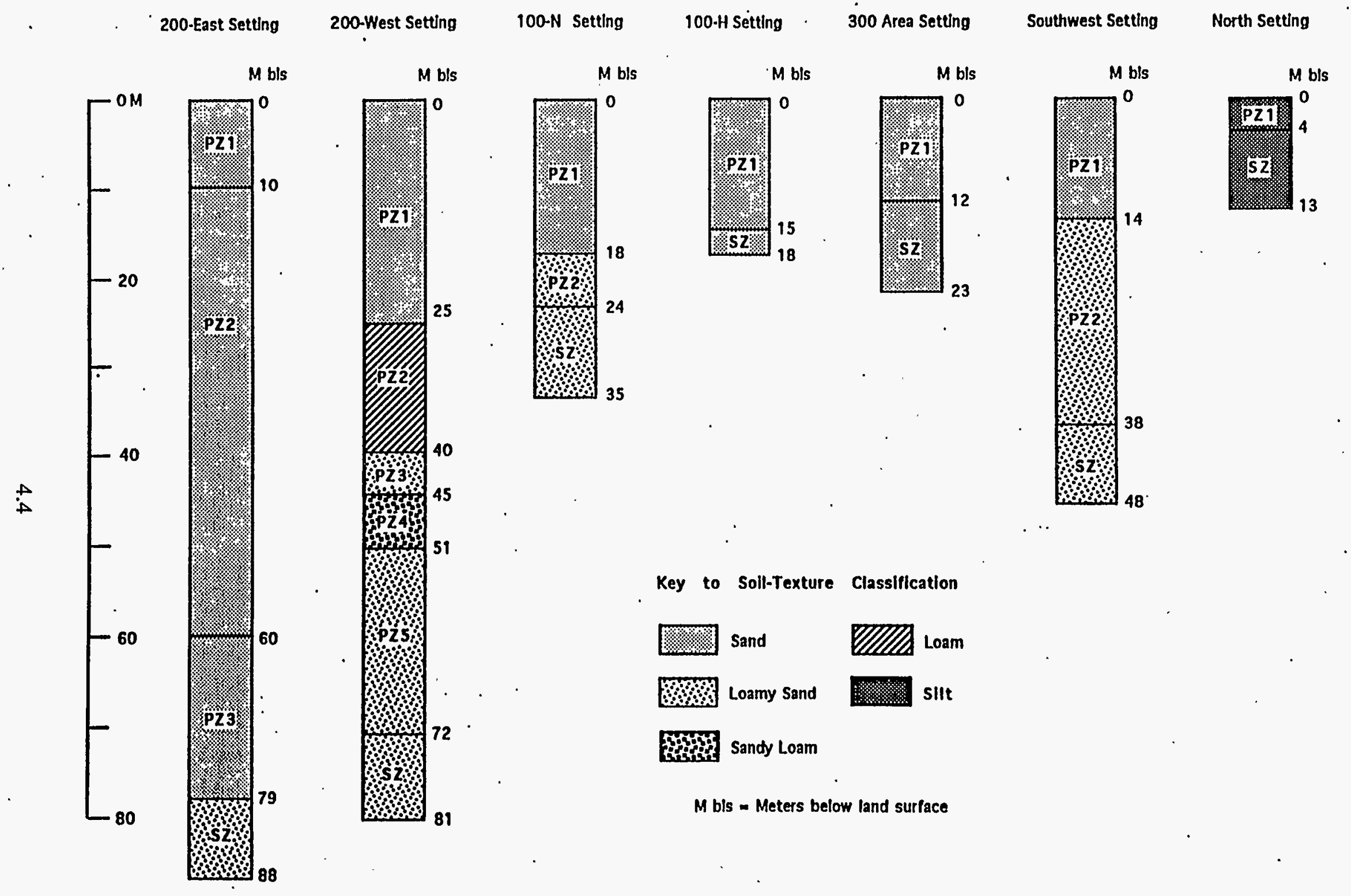

Figure 4.2 Stratigraphic Columns for Hanford Site Environmental Settings 


\subsubsection{200-West Area}

The water table in the 200-West Area occurs in the Ringold Formation. Reported hydrostratigraphic units above the water table include eolian deposits, the Hanford formation coarse-grained facies, the Hanford formation slackwater facies, the early Palouse soil, the Plio-Pleistocene unit, the upper Ringold unit, and the unsaturated portion of Ringold unit E. The five partially saturated zones selected to represent this environmental setting are the Hanford formation coarse-grained facies, the Hanford formation slackwater facies, the Plio-Pleistocene unit, the upper Ringold unit, and the Ringold unit $\mathrm{E}$. The surficial eolian deposit was not included because of a lack of data for these deposits and their variable thickness. Because of the possibility that some of the early Palouse soil samples may have been misidentified, the Hanford formation slackwater beds and the early Palouse soil unit were combined. The upper Ringold unit is not continuous throughout the 200-West Area; however, this unit was included because of its potential significant impact on infiltration.in the 200-West Area.

In the 200-West Area, the unconfined aquifer occurs in Ringold Formation gravel unit E, except in the northwestern part of the setting, where the aquifer occurs in gravel unit A. The reported thickness of the unconfined aquifer is up to $84 \mathrm{~m}$. However, the contaminated portion of the aquifer is generally accepted to be $9 \mathrm{~m}$, so this thickness was selected to represent the effective aquifer thickness.

\subsection{Idaho National Engineering Laboratory}

The INEL site is located in the southeastern part of Idaho, approximately equidistant from Yellowstone National Park; Salt Lake City, Utah; and Boise, Idaho (Figure 4.3). The INEL is situated along the western edge of the Eastern Snake River Plains at an elevation of $1,500 \mathrm{~m}$ and encompasses a desert area of $\sim 2,300 \mathrm{~km}^{2}$. The INEL extends $63 \mathrm{~km}$ from north to south and is $\sim 58 \mathrm{~km}$ wide at this broader southern part. The nearest major community is Idaho Falls, located $-64 \mathrm{~km}$ east of INEL and has a population of $\sim 46,000$.

The underlying rocks at INEL include basaltic lava flows interbedded with sediments to depths of several thousand meters. This system of basalt rocks and interbedded sedimentary sequences makes the major groundwater unit beneath the INEL site referred to as the Snake River Plain Aquifer. Although the general groundwater-flow patterns at the INEL are understood (Barraclough et al. 1981; Lewis and Jensen 1985), the subsurface is heterogeneous and, as a result, specific flow paths may be complex. This aquifer system is a major water supply in the region and is considered a sole-source aquifer. Water in this aquifer discharges to the Snake River several hundred kilometers downgradient from the site.

Surface drainage at INEL does not connect to the Snake River (the largest major river in the region). Three river drainages do exist at the INEL: 1) Big Lost River enters the INEL at its southwestern boundary, 2) Little Lost River, and 3) Birch Creek enters the INEL at its northern boundary. During most years, the Big Lost River terminates near the INEL's boundary in a series of diversion ponds constructed during the 1970s. During episodes of high flow, surfacewater from the Big Lost River moves in the channel past several of the major facilities to a series of natural playas in the 


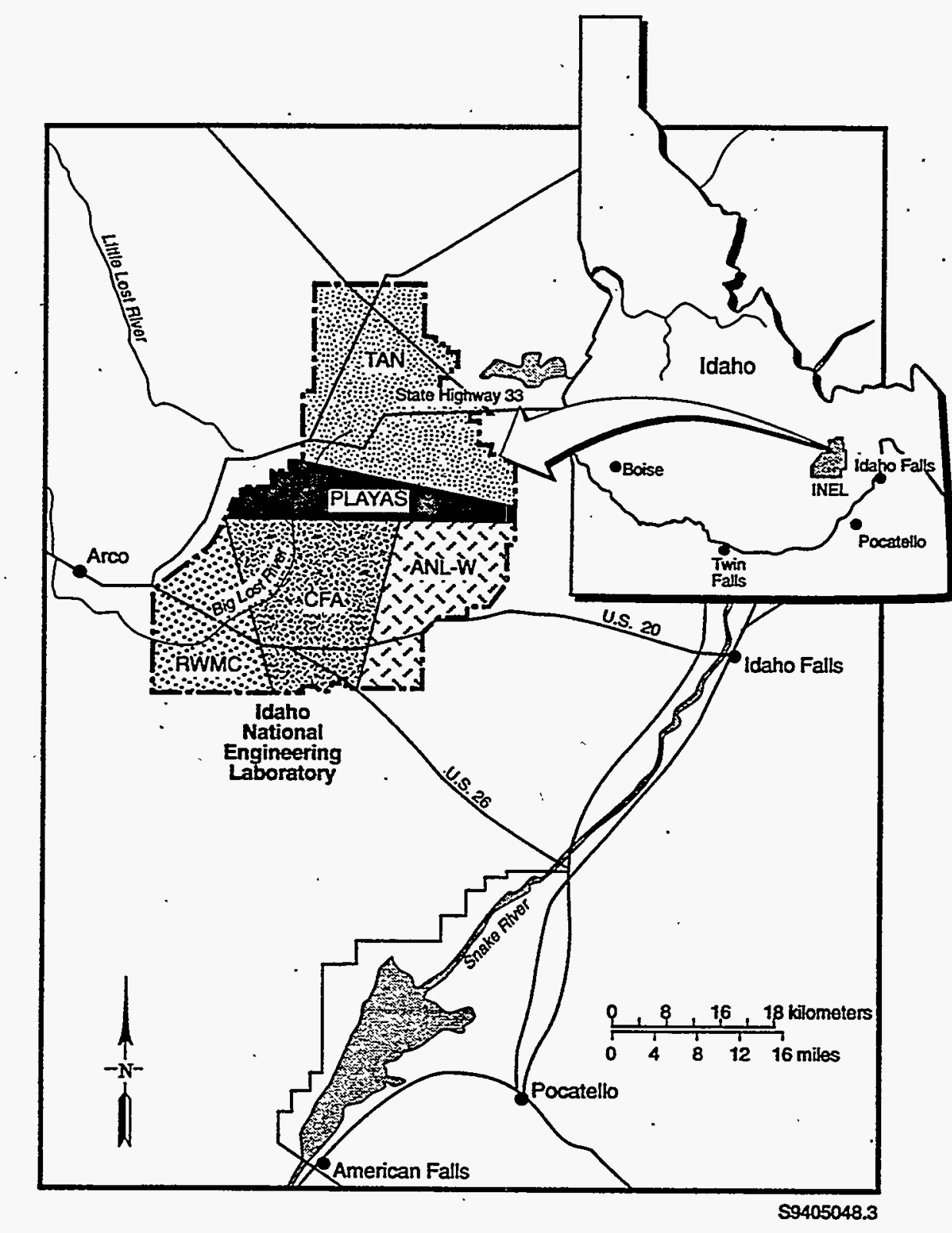

Figure 4.3. Location and Environmental Settings for the Idaho National Engineering Laboratory (INEL). For modeling purposes, INEL is divided into five environmental settings: Technical Area North (TAN), the Playas, Central Facilities Area (CFA), Radioactive Waste Management Center (RWMC), and Argonne National Laboratory-West (ANL-W).

INEL's northcentral portion. During most years, all surfacewaters in the Little Lost River and Birch Creek watersheds are diverted to irrigation before entering the INEL. During periods of high flow, surfacewaters from these two streams can reach the playas. 


\subsubsection{TRU Waste Storage}

The TRU wastes generated at INEL have been stored within the Radioactive Waste Management Complex (RWMC). TRU wastes generated since 1970 have been segregated from other wastes within 'the complex and are stored on asphalt pads in steel drums, steel boxes, and fiberglass-covered wooden boxes. Some of the waste buried at the RWMC before 1970 is contaminated with TRU radionuclides.

More complete descriptions of the INEL, the RWMC, the TRU waste-storage and -examination facility, and the TRU waste stored on the Transuranic Storage Area pads can be found in DOE (1986).

\subsubsection{Local Environmental Setting}

For purposes of this analysis, TRU wastes were assumed to be stored in the RWMC setting (see Figure 4.3); one of the five hydrogeologic environmental settings used to represent the INEL in Holdren et al. (1995). Figure 4.4 presents stratigraphic columns for each of these settings. Hydrogeologic data for the settings are preserited in Holdren et al. (1995, Tables 6.2 through 6.5). A brief description of the hydrogeology of the RWMC setting is as follows.

The meteorological and atmospheric dispersion data in the form of a joint-frequency distribution of wind direction, wind speed, and atmospheric stability used in this analysis for INEL are presented in Bergenback et al. (1995).

\subsubsection{RWMC Setting}

The RWMC setting is located on the southern and western margins of the INEL. The Big Lost River enters this setting from the west. During most years, flow from the river is terminated in a series of diversion ponds constructed near the southwestern corner of the INEL. The stratigraphy within the partially saturated zones at the RWMC is complex, consisting of a series of basalt flows and interbedded sediments. As found in other areas within INEL, the basalts in this area tend to be vertical and, thus, allow for the rapid migration of contaminants downward through these zones. A number of the sedimentary interbeds are dominated by sands and gravels and, as such, offer little resistance to the migration of contaminants. One sedimentary zone, however, is predominantly fine grained and is capable of significantly retarding the migration of radionuclides. As a result of this distribution of hydraulic characteristics at the RWMC, this setting has been divided into four partially saturated zones and one saturated zone. The first partially saturated zone consists of surface sediments and soils. The second and fourth zones are modeled as vertically fractured basalts, and the third partially saturated zone attempts to describe the fine-grained sedimentary interbed located at a depth of $\sim 64 \mathrm{~m}$. Depth to groundwater in this area is greater than at other areas at INEL. The total thickness of the partially saturated zone is modeled at $\sim 180 \mathrm{~m}$.

Groundwater moves off the INEL through its southern boundary. This boundary includes sections of the RWMC, the Central Facilities Area (CFA), and the Argonne National Laboratory-West 

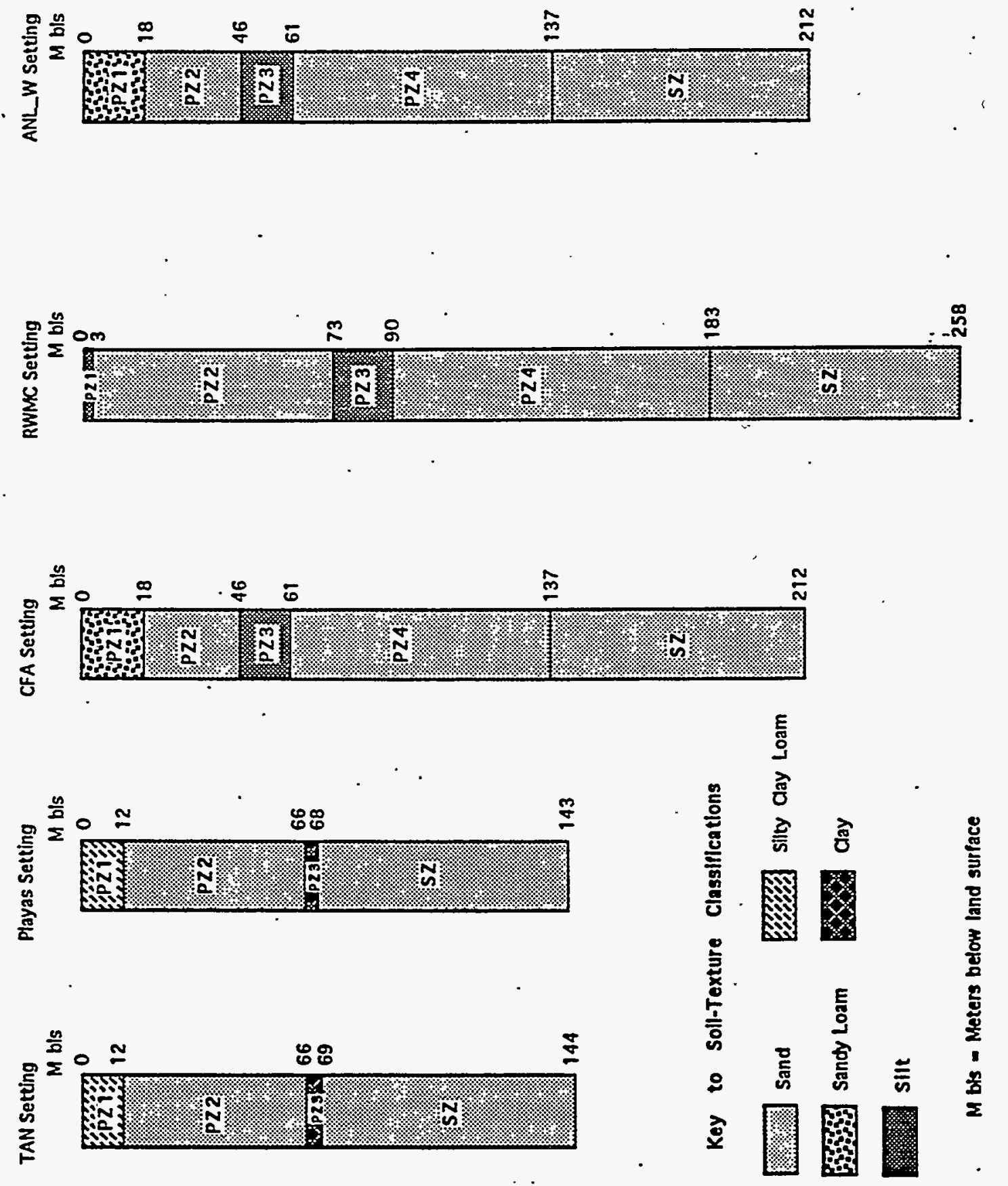
(ANL-W) hydrogeologic settings. This groundwater is discharged to surfacewaters several hundred kilometers downgradient at springs and șeeps along the Snake River.

\subsection{Lawrence Livermore National Laboratory}

The LLNL occupies $3.3 \mathrm{~km}^{2}$ in the Livermore Valley, a depression within the Diablo Range of the California Coast Range Province (Figure 4.5). LLNL has two separate sites: the main Livermore site and Site 300. The main site is located near the eastern boundary of the city of Livermore, California, $\sim 55 \mathrm{~km}$ ) east of downtown San Francisco. Site 300 is located in the Altamont Hills of the Diablo Range, $\sim 24 \mathrm{~km}$ east of the main site. The area surrounding LLNL is used for residential, industrial, commercial, and agricultural activities.

Within the Livermore Valley, valley-fill deposit can be divided into three separate units:

1) Pleistocene- and Holocene-aged alluvium, 2) upper Livermore Formation, and 3) lower Livermore Formation (Sims et al. 1990). The upper Livermore Formation beneath LLNL is made up of complexly interfingered alluvial deposits of highly variable permeability and thickness. The morepermeable deposits vary in thickness from 1 to $10 \mathrm{~m}$. The less-permeable sediments are commonly 1to 7-m thick and can be as much as $25-\mathrm{m}$ thick. Deposits of the upper Livermore Formation are nearly identical to the overlying Pliestocene- and Holocene-aged alluvial deposits. The permeable parts of the upper and lower Livermore Formations are separated by a horizontally extensive, low-permeability, confining layer that occurs near the upper part of the lower Livermore Formation (Layton et al. 1990).

Groundwater is generally found in two aquifer systems at LLNL: 1) an upper, shallow aquifer system in the alluvium and upper Livermore Formation and 2) a lower, confined aquifer system within the lower Livermore Formation. Owing to the presence of the low-permeability sediments in the upper 10 to $30 \mathrm{~m}$ of the lower Livermore Formation, little or no hydraulic communication is thought to occur between the upper and lower aquifer systems (Layton et al. 1990). Natural recharge occurs primarily along the fringes of the basin and through arroyos during periods of winter flow. Groundwater movement in the valley is toward the central east-west axis of the valley and then westward to the Central Basin (Sims et al. 1990).

No perennial surfacewater can be found near LLNL (Layton et al. 1990). When it exists, it generally drains from the main site to the west to arroyos and intermittent streams.

\subsubsection{TRU Waste Storage}

Small amounts of mixed wastes $\left(\sim 214 \mathrm{~m}^{3}\right)$ are currently stored at the LLNL main site as a result of laboratory operations in connection with nuclear weapons research and development. A small percentage of this waste is mixed TRU wastes that are considered RH TRU wastes and subject to land-disposal restriction requirements. The mixed TRU wastes consist of 1) inorganic debris, which includes scrap metal, metal shavings, and lead bricks; 2) aqueous liquids from metal etching; and 3) organic liquids, such as spent solvents. 


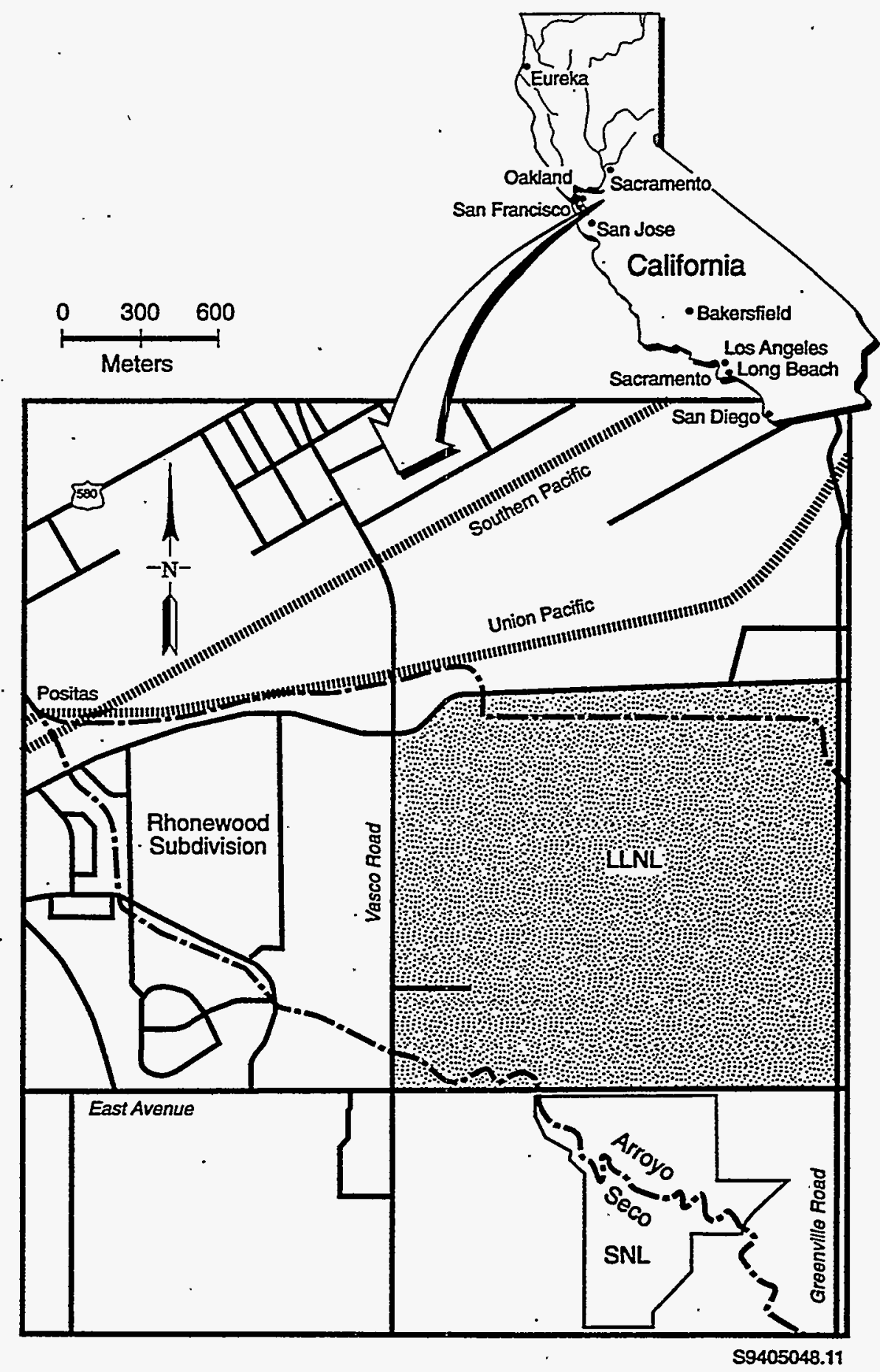

Figure 4.5. Location and Environmental Settings for the Lawrence Livermore National Laboratory (LLNL). For modeling purposes, LLNL is characterized by a single environmental setting. 


\subsubsection{Local Environmental Setting}

For purposes of this analysis, TRU wastes were assumed to be stored in the main setting (see Figure 4.5); one of the eleven hydrogeologic environmental settings used to represent LLNL in Holdren et al. (1995). Figure 4.6 presents the stratigraphic column for the main setting. Hydrogeologic data for the main setting are presented in Holdren et al. (1995, Table 11.1). A brief description of the hydrogeology of this setting is as follows.

The main setting is assumed to have one partially saturated zone and one saturated zone as depicted in Figure 4.6. Although alluvial sediments of the main setting are quite heterogeneous, the heterogeneity is too fine a scale to be captured by the approach used in this analysis. Input parameters for the unsaturated and saturated zones given in Holdren et al. (1995) were derived from information provided in Layton et al. (1990).

The meteorological and atmospheric dispersion data in the form of a joint-frequency distribution of wind direction, wind speed, and atmospheric stability used in this analysis for the LLNL are presented in Bergenback et al (1995).

\subsection{Los Alamos National Laboratory}

The LANL encompasses $110 \mathrm{~km}^{2}$ in northcentral New Mexico and is located on long, narrow mesas, whose tops range in elevation from 2,400 m on the flanks of the Jemez Mountains to $\sim 1,900 \mathrm{~m}$ at their eastern termination above the Rio Grande Valley. LANL is situated $-97 \mathrm{~km}$ north-northeast of Albuquerque, New Mexico, and $40 \mathrm{~km}$ northwest of Santa Fe (Figure 4.7).

Major rock units beneath LANL, from oldest to youngest, include the Tesuque Formation sediments, the Chino Mesa Formation basalts, the Puye Formation conglomerates, the Tschicoma Formation volcanics, and the Bandelier Tuff. Groundwater at LANL occurs within shallow alluvium, perched aquifers found within the rock units identified above. A main regional aquifer is found in the Sante Fe Group sediments, which include parts of the Tesuque and Puye Formations.

Groundwater occurs in three modes in the LANL area: 1) water in shallow alluvium in some of the larger canyons, 2) perched water, and 3) main aquifer of the Los Alamos area (LANL 1992). Intermittent and ephemeral stream flows in the canyons of the Pajarito Plateau have deposited alluvium that ranges in thickness to as much as $30 \mathrm{~m}$. Perched water at LANL occurs in conglomerates and basalts beneath the alluvium in a limited area in the mid-reach of the Pueblo Canyon and in a second area near the confluence of lower Pueblo and Los Alamos canyons.

The main aquifer is the only aquifer capable of supplying municipal and industrial water for the LANL area. The upper surface of the main aquifer rises westward from the Rio Grande River through the Tesuque Formation and lower Puye Formation conglomerate beneath the central and western 
$\mathrm{M}$ bls

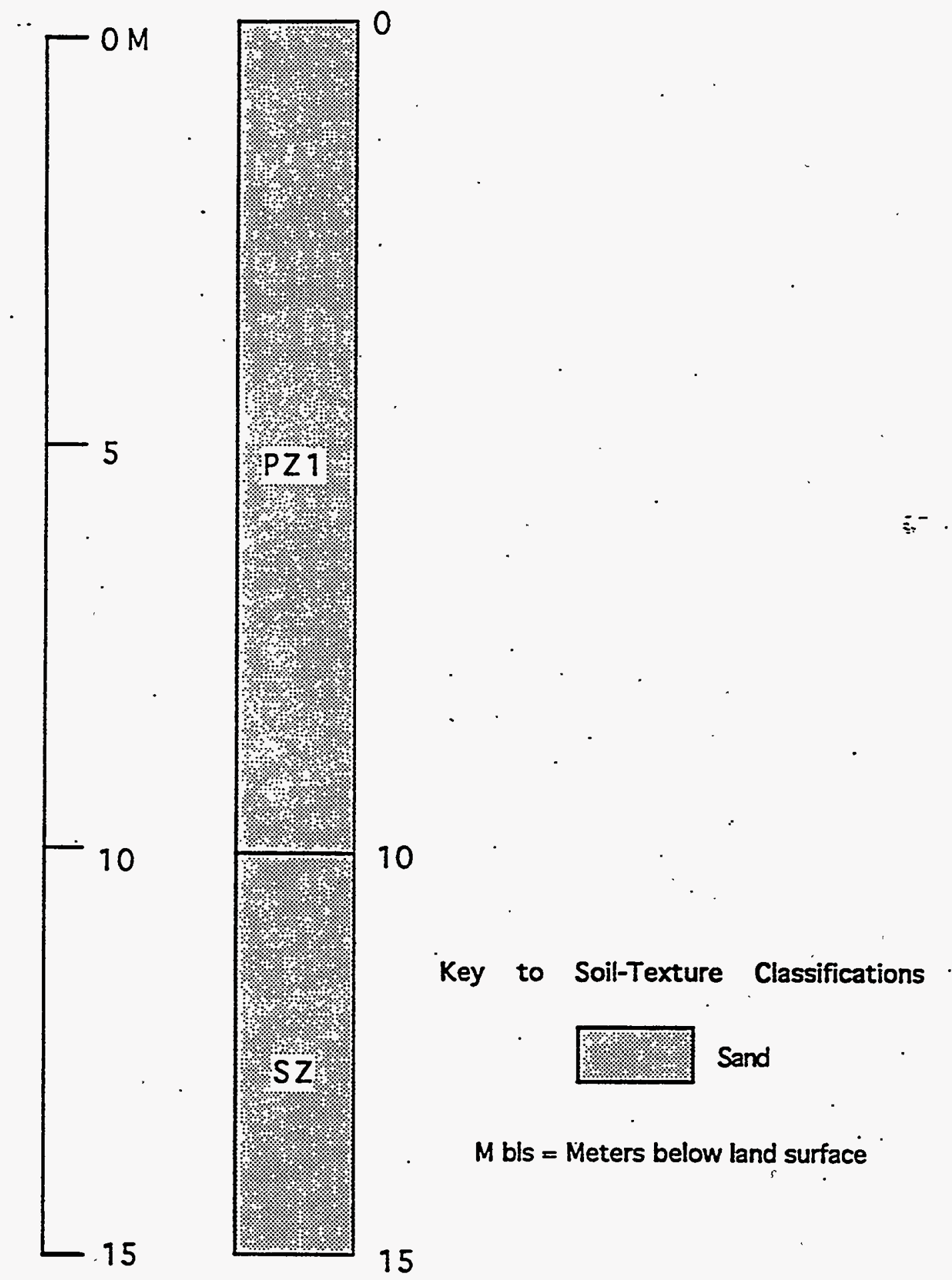

Figure 4.6. Stratigraphic.Column for Lawrence Livermore National Laboratory Environmental Setting 4.12 


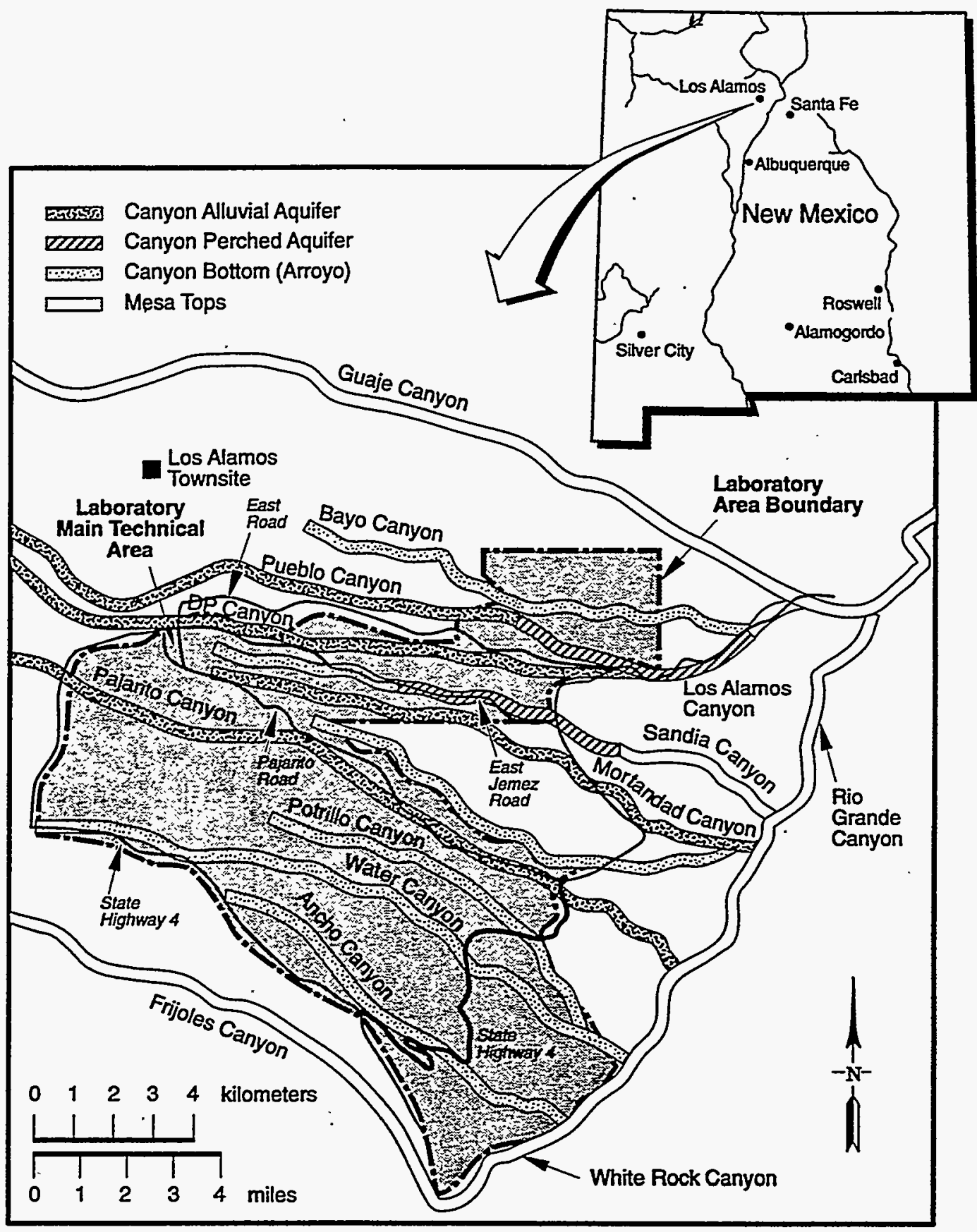

$\$ 9405048.4$

Figure 4.7. Location and Environmental Settings for the Los Alamos National Laboratory (LANL). For modeling purposes, LANL is divided into four environmental settings: Mesa Tops, Arroyos, Alluvial Canyons, and Canyons with Perched Aquifers. The Mesa Tops setting characterizes the majority of LANL. The other settings are associated with canyons and arroyos distributed across the installation. 
portions of the plateau (DOE 1979; LANL 1992). The surfacewater and groundwater in the alluvium are separated from water in the main aquifer by several hundred meters of unsaturated volcanic tuff and sediments (LANL 1992).

The major surfacewater feature of the LANL area is the Rio Grande River, which flows southward, with a drainage area of $-37,00 \mathrm{~km}^{2}$ in southern Colorado and northem New Mexico. The eastern margin of the Pajarito Plateau stands $\sim 90$ to $275 \mathrm{~m}$ above the Rio Grande River (LANL 1992). In the LANL area, there is intermittent stream flow in canyons cut into the Pajarito Plateau. Perennial flow to the Rio Grande River occurs in canyons north and south of LANL.

\subsubsection{TRU Waste Storage}

Since 1971, TRU waste has been packaged and stored in either subsurface trenches or aboveground earthen berms at the waste-burial site. Two types of packaging have generally been used. Small items have been stored in 208-L steel drums (sealed and coated with bituminous corrosion-protection material), and larger items have been placed in plywood crates (sealed and coated with fiberglass-reinforced polyester). Plywood storage crate sizes vary considerably, with a maximum length of $\sim 9 \mathrm{~m}$.

\subsubsection{Local Environmental Setting}

For purposes of this analysis, TRU wastes were assumed to be stored in the Mesa Tops setting (see Figure 4.7); one of the four hydrogeologic environmental settings used to represent LANL in Holdren et al. (1995). Figure 4.8 presents stratigraphic columns for each of these settings. Hydrogeologic data for the various settings are presented in Holdren et al. (1995, Tables 12.1 through 12.4). A brief description of the hydrogeology of the Mesa Tops setting for LANL is as follows.

The main aquifer at LANL is encountered at depths either below the previously discussed canyon bottoms or below the various finger-like mesas of the Pajarito Plateau. Mesa tops are capped with the Bandelier Tuff and its two members, the Tshirege and the Otowi. Proceeding west to east across the Pajarito Plateau, the thickness of the Bandelier Tuff ranges from 320 to $80 \mathrm{~m}$ (DOE 1979). Values for the hydrogeologic parameters used to represent the Mesa Tops environmental setting are primarily based on data from deep well EGH-LA-1, located in the northcentral portion of the Pajarito Plateau between Mortandad and Sandia canyons (see Figure 4.7). Thickness of the partially saturated zone is $\sim 400 \mathrm{~m}$, based on depth-to-water measurements (LANL 1993). Thickness of the saturated zone is $-370 \mathrm{~m}$, based on an estimated thickness of potable water in the main aquifer (DOE 1979). Hydraulic conductivity estimates and soil-texture classifications were performed as above in the Canyon Alluvial Aquifer, Canyon Perched Aquifer, and Canyon Bottom settings.

The meteorological and atmospheric dispersion data in the form of a joint-frequency distribution of wind direction, wind speed, and atmospheric stability used in this analysis for LANL are presented in Bergenback et al. (1995). 


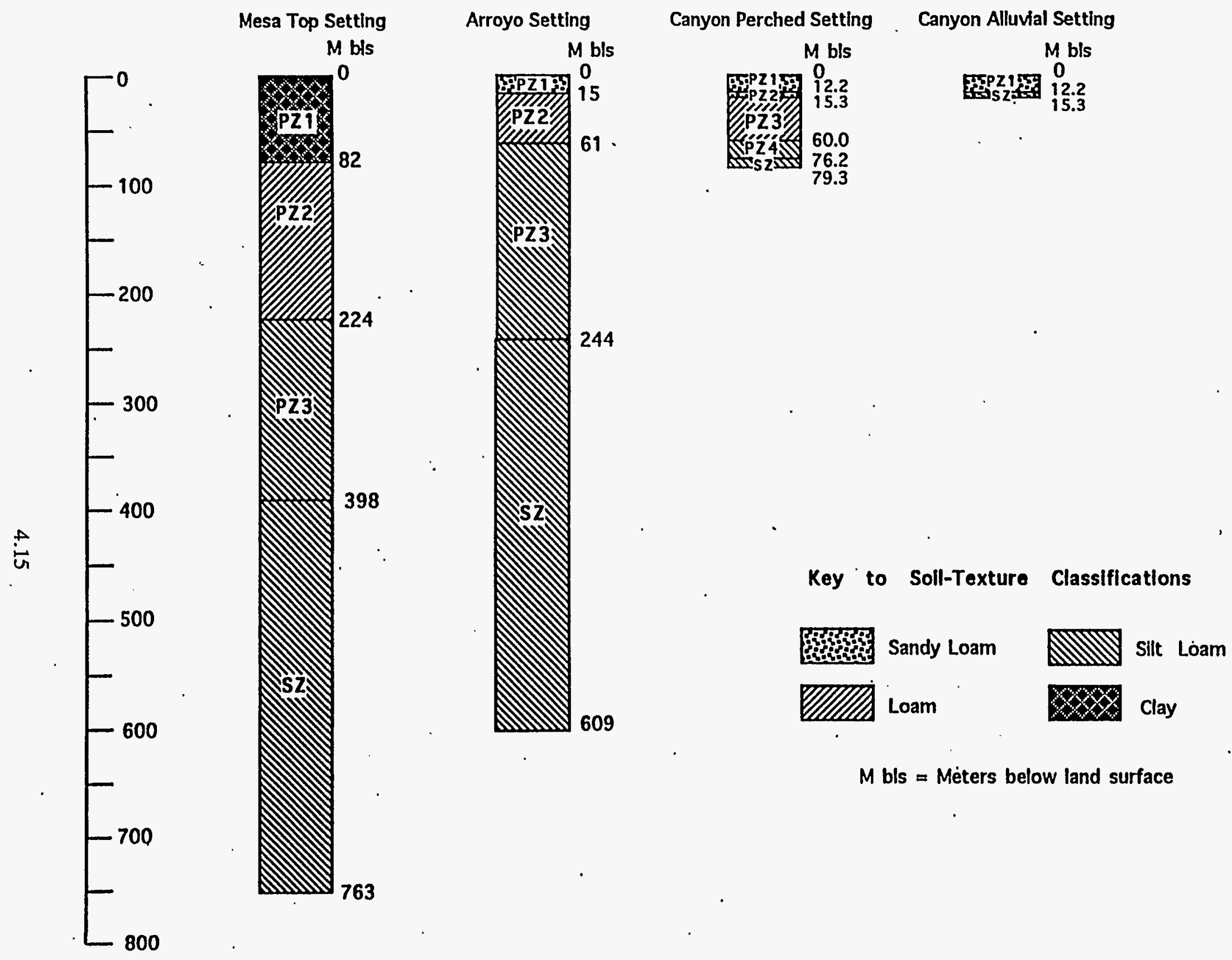

Figure 4.8 Stratigraphic Columns for Los Alamos National Laboratory Environmental Settings 


\subsection{Oak Ridge National Laboratory}

The ORNL is located on $36 \mathrm{~km}^{2}$ in the southcentral portion of the 140-km² Oak Ridge Reservation (ORR) (Figure 4.9). The ORR is located $-32 \mathrm{~km}$ west of Knoxville, Tennessee, in the rolling terrain between the Cumberland and Great Smoky Mountains. The land surrounding the ORR is primarily rural, dominated by agricultural and residential land. The main laboratory area (designated as the X-10 facility) takes up only $-15 \%$ of the ORR grounds.

The ORR is located in the Bethel and Melton Valleys, part of the Tennessee Valley and Ridge Province of the Southern Appalachian fold and thrust belt. The area is characterized by a succession of northeast-trending thrust faults that stack and repeat the Paleozoic section. As a result of thrusting and subsequent differential erosion, a series of ridges, consisting of relatively resistant rocks (e.g., sandstone, shale, and dolomite), and valleys developed in more easily eroded material (e.g., less-resistant carbonate and shale). Most of the units dip steeply toward the south-southeast. This structure has a major role in regulating groundwater movement in the area. The main area is situated in the Bethel Valley; Chestnut Ridge lies to the north and Haw Ridge lies to the south. Chestnut Ridge is formed from the Knox Group, which is a deeply weathered cherty dolomite. The Bethel Valley is underlain by the Chickamauga Limestone, which consists of silty limestones and calcareous siltstones. Haw Ridge is formed from the Rome Formation, consisting of sandstones, siltstones, and shales. The Melton Valley, located south of Haw Ridge, is underlain by the Conasauga Group, which consists of calcareous shales interlayered with limestone and siltstone. The Copper Creek fault lies south of the main area of Haw Ridge. Fracturing is pervasive throughout all rock units at the ORR and also occurs in zones that are associated with faults. Although the rock units are highly fractured, most have been filled with mineral precipitates (predominantly calcite) and do not contribute to a secondary permeability. Karstification, or solution enlargement of existing fractures, is common in the more carbonate-rich units and has been reported from the Knox Group and Chickamauga Group (Martin Marietta Energy Systems, Inc. 1989).

Although groundwater occurs in all formations that crop out at the ORR, three major hydrologic units are present. Mechanisms and rates of flow appear to be controlled by topography, structure, and lithology. The first hydrologic unit is a near-surface storm-flow zone that extends across all of the ORR (as well as other ORR areas). Because of its proximity to the surface, there are no clearly defined, partially saturated zones that overlie the storm-flow zone. The storm-flow zone transmits $90 \%$ of the incoming precipitation laterally to surfacewater. The remaining $10 \%$ infiltrates to underlying aquifers. The second hydrologic unit is the Knox aquifer, which includes areas underlain by the Knox Group and the Maynardville Limestone Member of the Conasauga Group. The third hydrologic unit is the ORR aquitards, consisting of areas underlain by all other geologic formations. Vertical movement of these waters tends to occur along contact zones between major lithologic units. Therefore, soil waters generally move down dip until reaching a zone of saturation, where they then tend to migrate along strike until reaching an area of discharge.

The Clinch River is the major surfacewater source that receives discharges from the ORR. Four Tennessee Valley Authority reservoirs influence the flow and/or water levels of the lower Clinch River: Norris and Melton Hill on the Clinch River and Watts Bar and Fort Loudon on the Tennessee 


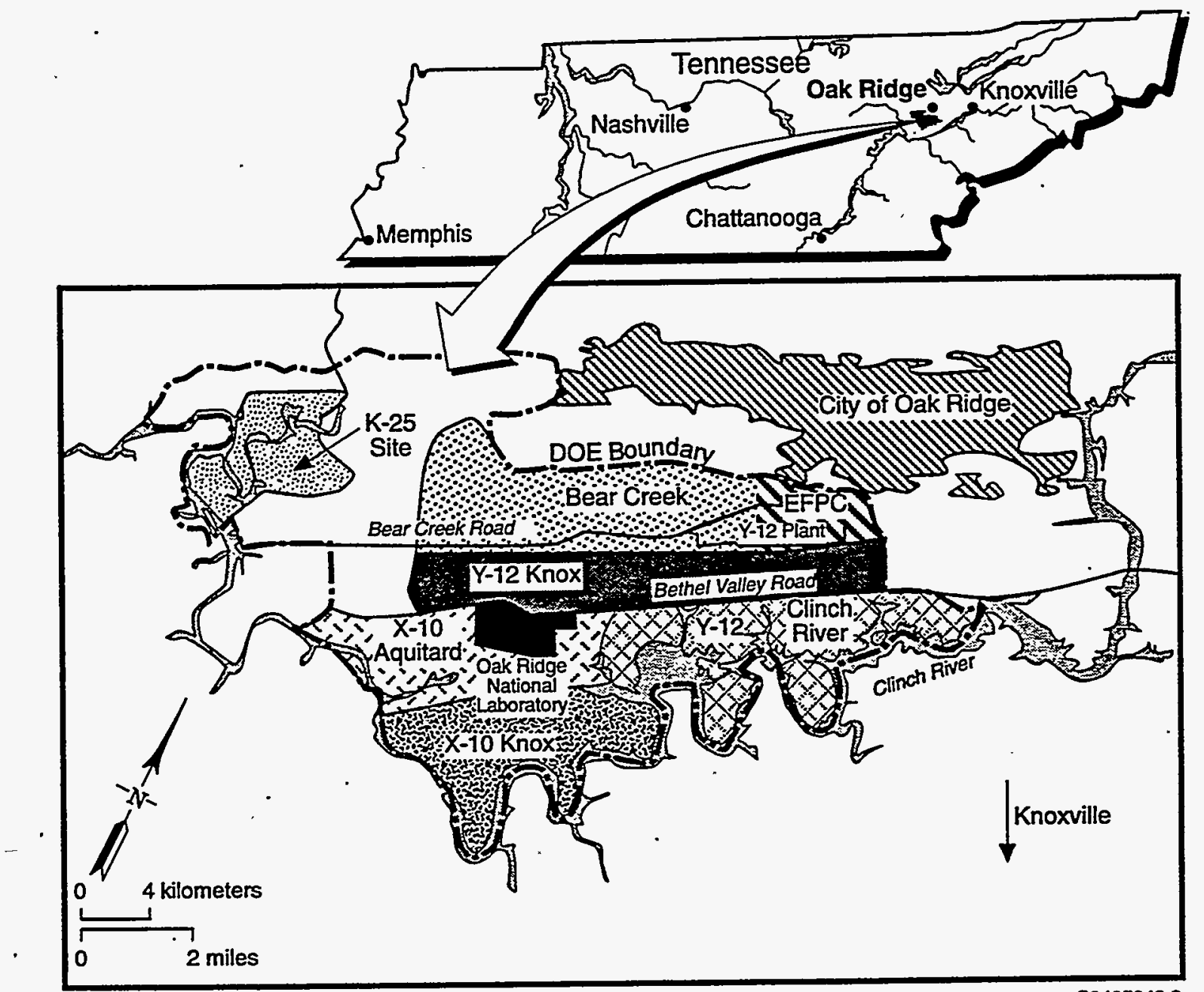

$\$ 9405048.2$

Figure 4.9. Location and Environmental Settings for the Oak Ridge Reservation (ORR). For modeling purposes, the $\mathrm{K}-25$ site is characterized by a single environmental setting; the Oak Ridge National Laboratory is divided into three environmental settings (the Storm-Flow Zone, Knox, and Aquitard settings); and the Y-12 installation is divided into seven environmental settings (the Bear Creek Aquitard, Bear Creek Storm-Flow, East Fork Poplar Creek [EFPC] aquitard, EFPC Storm-Flow, Y-12 Knox, Clinch River aquitard, and Clinch River Storm-Flow). Storm-flow zones and other installation zones cover the same area.

River. The ORR is bounded on the south and west by a $63-\mathrm{km}$ stretch of the Clinch River. Melton Hill Dam is located at Clinch River kilometer 37.2 (river mile 23), forming the Melton Hill Reservoir and several major embayments that bound the ORR. Both groundwater and surfacewater are drained from the ORR by a network of small tributaries of the Clinch River. The ORR drains into White Oak Creek and Melton Branch, which both drain into the Clinch River (Martin Marietta Energy Systems, Inc. 1989). 


\subsubsection{TRU Waste Storage}

The TRU waste is generated in the main ORNL complex, primarily in the Isotopes Area and the Radiochemical Engineering Development Center. Newly generated CH TRU waste is packaged in stainless steel drums at the point of generation and is transported within the site boundary to the TRU waste-storage area.

\subsubsection{Local Environmental Setting}

For purposes of this analysis, TRU wastes were assumed to be stored in the Knox environmental setting (see Figure 4.9); one of the three hydrogeologic environmental settings used to represent the ORNL in Holdren et al. (1995). The storm-flow zone has no partially saturated zones associated with it. The Knox and Aquitard settings share a series of four partially saturated zones, named inceptisol 1 (silt loam), inceptisol 2 (sandy loam), ultisol 1 (silt loam), and ultisol 2 (clay loam). The combined thickness of the four partially saturated zones is $8 \mathrm{~m}$. Figure 4.10 presents stratigraphic columns for each of these settings. Hydrogeologic data for the various settings are presented in Holdren et al. (1995, Tables 17.1 through 17.4). A brief description of the hydrogeology of the Knox setting is as follows.

In the general hydrologic framework developed by hydrogeologists at ORNL, there are two hydrostratigraphic units controlling groundwater flow. These are designated the Knox aquifer and the ORR aquitards. The Knox aquifer consists of the Knox Group and the underlying Maynardville Limestone Member of the Conasauga Group. The aquitard zone inciudes all rock formations other than those comprising the Knox Group. For this analysis, an environmental setting is included for each of these zones, designated as the Knox and Aquitard settings. Measurements of thicknesses, total porosities, fracture porosities, and matrix conductivities are discussed in Moore and Toran (1992). Specific yields were computed from hydrograph analysis for Ish Creek and the headwaters of the Melton Branch. Storage capacity was calculated from specific yield and average water-table fluctuation. Conductivity was calculated from the average transmissivity, as measured from slug tests, and the thickness of each unit. Hydraulic gradient was measured on water-table maps. The hydraulic gradient and the conductivity were used to estimate groundwater velocities.

The meteorological and atmospheric dispersion data in the form of a joint-frequency distribution of wind direction, wind speed, and atmospheric stability used in this analysis for ORNL are presented in Bergenback et al. (1995). 


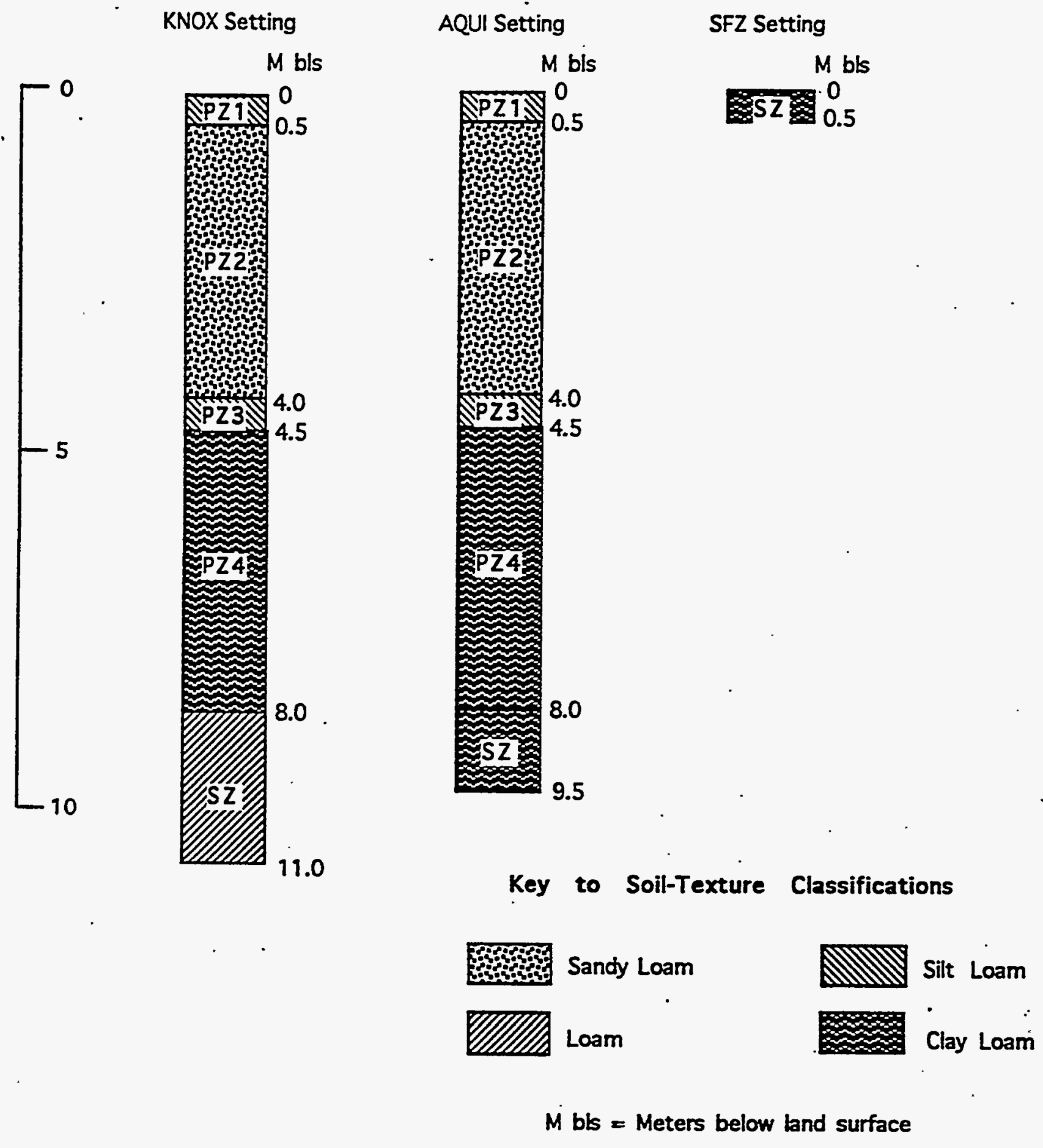

Figure 4.10. Stratigraphic Columns for Oak Ridge National Laboratory Environmental Settings 


\subsection{Rocky Flats Environmental Technology Site}

The RFETS is located east of the foothills of the Rocky Mountains $-26 \mathrm{~km}$ northwest of Denver, Colorado (Figure 4.11). The RFETS is situated in a generally rural area outside the Denver metropoli$\tan$ area, with some ranches and industrial facilities located nearby. The installation occupies $27 \mathrm{~km}^{2}$, with its facilities centrally located on only $\sim 6 \%$ of the property. The topography of the RFETS is relatively flat.

The RFETS is located on Quaternary-aged alluvial and fluvial deposits. The Rocky Flats alluvium is the dominant unit associated with the oroad, flat-lying areas on the western half of the site. The thickness of the alluvium varies across the site. Near the western boundary, the alluvium can exceed $15 \mathrm{~m}$ but gradually pinches out toward the middle of the site. Surficial deposits in the central portions of the plant are primary colluvium. These deposits are generally thin and tend to cover the slopes and floors of ravines located north and south of the main facility. Valley fill, which is essentially fluvially reworked Rocky Flats alluvium, is found in the eastern portion of the site. Bedrock in the vicinity of the plant is of Cretaceous age and dips gently toward the east. The uppermost unit is the Arapahoe Formation, a light to medium olive-gray sequence of claystones, siltstones, and sandstones. In general, the Arapahoe Formation has a low permeability and, hence, a major influence on the hydrology in the area. Directly beneath the Arapahoe Formation is the Laramie.Formation, a thick sequence consisting predominantly of claystones with a few water-bearing sand lenses. The Fox Hills sandstone (a confined aquifer) underlies the Laramie Formation.

Groundwater of concern is primarily the shallow aquifer overlying the Arapahoe Formation and is found within the Rocky Flats alluvium and valley fill. This unconfined aquifer is recharged directly by deposition in the vicinity of the RFETS and from areas west of the installation but east of the Front Range. Groundwater discharges to surfacewaters at seeps and springs along both Woman's and Walnut Creeks.

The RFETS has two major surface drainages. The northern half of the installation drains into Walnut Creek, a low-flow stream that flows through a series of small ponds on the plant property before eventually discharging into the Great Western Reservoir several kilometers east of the RFETS. Flow in the creek is primarily storm flow. Natural drainage on the southern half of the property feeds into Woman's Creek. Much of the storm flow and runoff from the facilities area is diverted to a drainage ditch that parallels Woman's Creek. Waters from the southern half of the property discharge to Standley Lake, a major surfacewater body located south and east of the installation.

\subsubsection{TRU Waste Storage}

The Rocky Flats Plant Supercompaction and Repackaging Facility and TRU Waste Shredder would process solid waste that is newly generated during routine production operations, maintenance activities, and laboratory-support operations and may process waste in permitted storage. The State of Colorado Department of Health currently recognizes eight permitted storage areas at the RFETS for TRU mixed waste. The areas differ in size for a total permitted storage capacity of $1,224 \mathrm{~m}^{3}$. The 


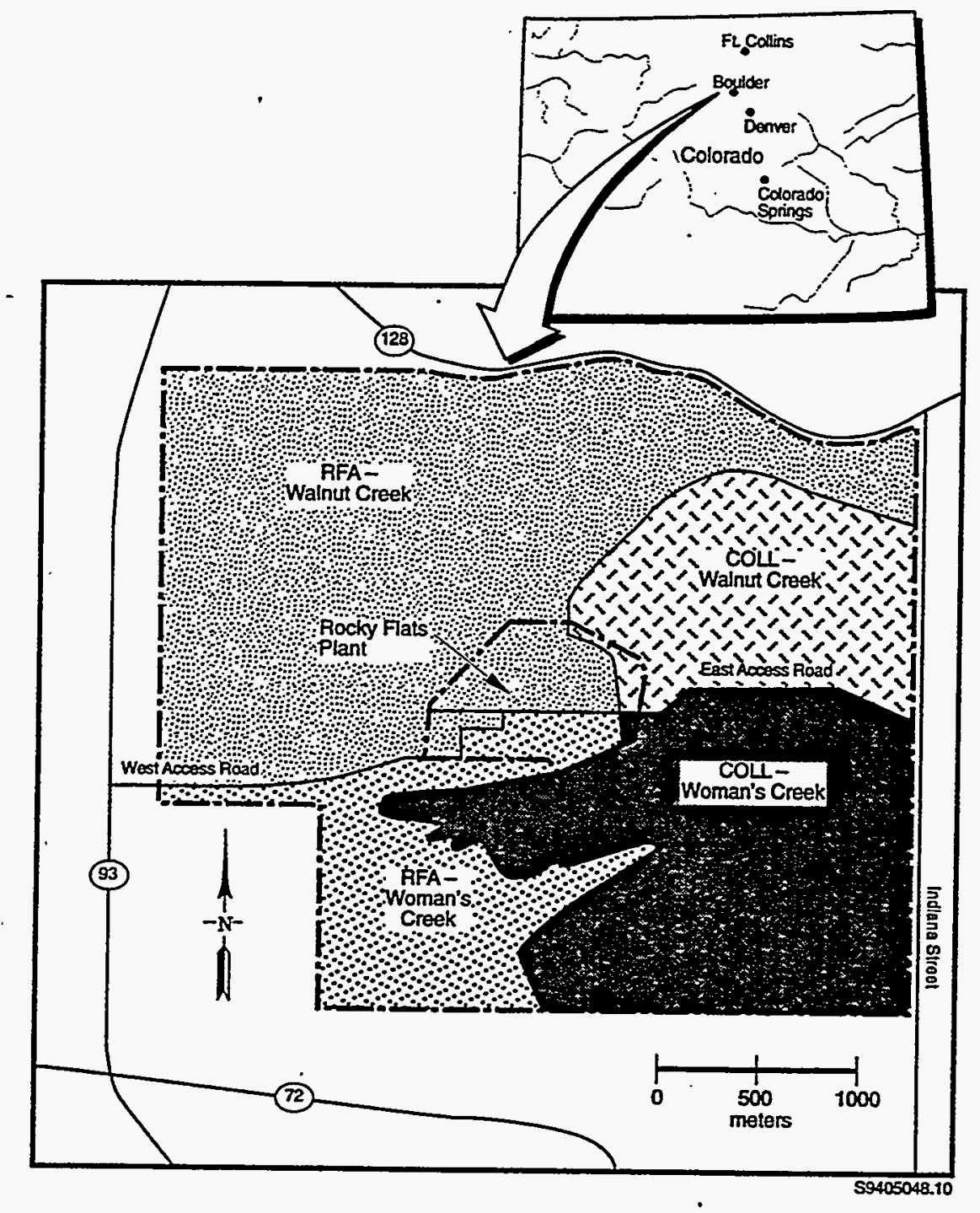

Figure 4.11. Location and Environmental Settings for the Rocky Flats Environmental Technology Site (RFETS). For modeling purposes, the RFETS is divided into five environmental settings: Woman's Creek with Surficial Rocky Flats Alluvium (RFA), Woman's Creek with Surficial Colluvium (COLL), Walnut Creek with Surficial RFA, Walnut Creek with Surficial COLL, and Operable Unit 3 (not shown).

storage units are within existing structures having concrete floors covered with epoxy paint and fenced areas within the buildings, which allow segregation of the storage facility from adjacent operations.

\subsubsection{Local Environmental Setting}

For purposes of this analysis, TRU wastes were assumed to be stored in the Operable Unit 3 setting; one of the five hydrogeologic environmental settings used to represent the RFETS in Holdren et al. (1995). Figure 4.12 presents stratigraphic columns for each of these settings. 


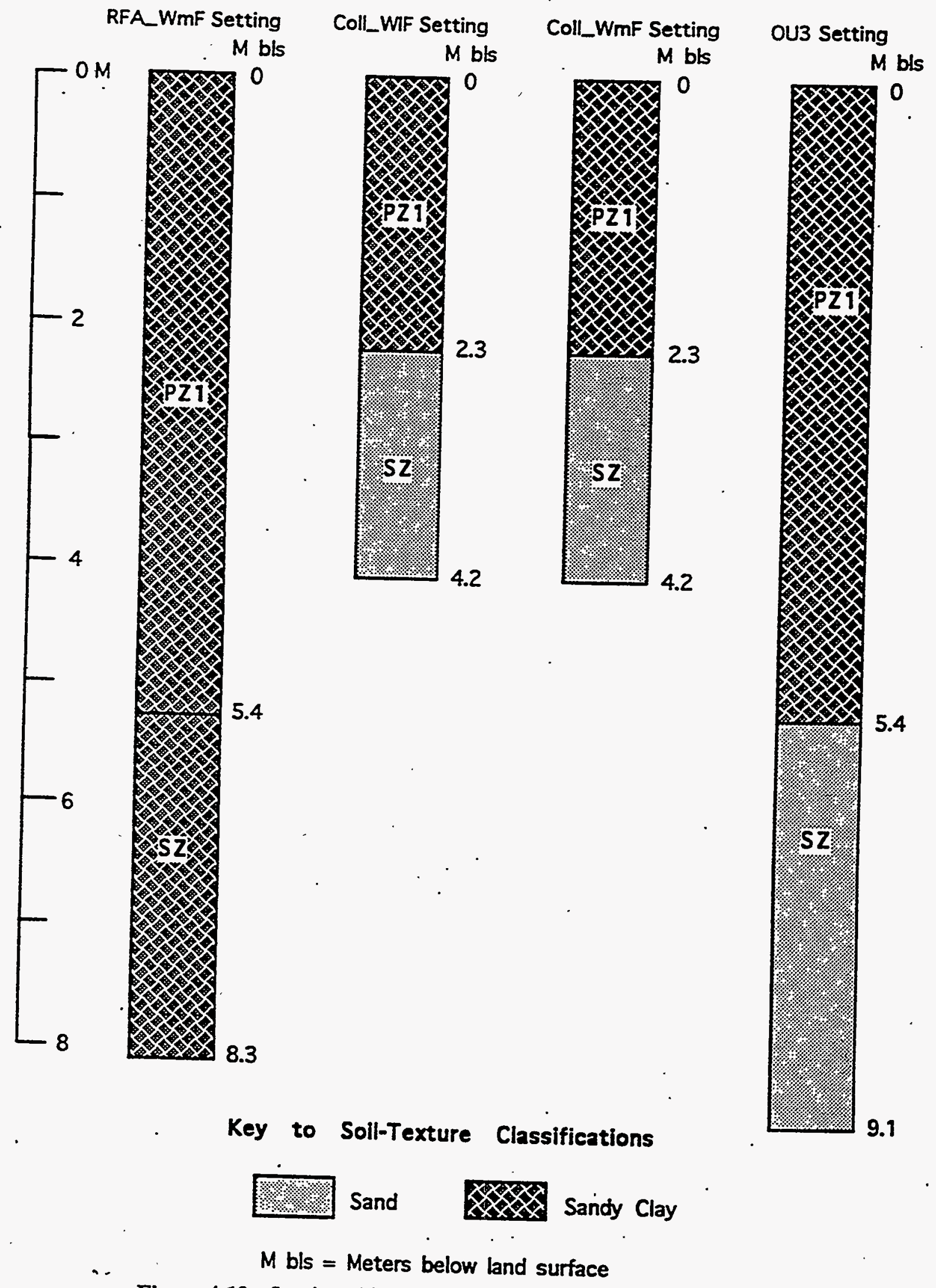

Figure 4.12. Stratigraphic Columns for Rocky Flats Environmental Technology Site Environmental Settings 
As previously described, the RFETS is built on alluvial materials derived from the Colorado Front Range. The bedrock in the area is gently dipping Cretaceous clay and siltstones, the uppermost of which is the Arapahoe Formation. Because of the impervious nature of these units, contaminant migration has been limited to the upper area that is divided into two separate settings, one in which Rocky Flats alluvium is modeled as the surficial material and one in which the more-permeable colluvium is modeled at the surface. Because colluvium is generally found in sideslopes and floors of the ravines, the thickness of the partially saturated zones associated with the colluvium are thinner than those modeled for the Rocky Flats alluvium. The fifth environmental setting was developed for Operable Unit 3, located east of the installation and adjacent to the Great Western Reservoir and.Standley Lake. This setting describes what is essentially the reworked Rocky Flats alluvium and is distinct because of the relatively shorter distances to drinking-water supplies. Surfacewater data are presented in Holdren et al: (1995, Table 23:1). Hydrogeologic data for the various settings are also presented in.Holdren et al. (1995, Table 23.2 through 23.5).

The meteorological and atmospheric dispersion data in the form of a joint-frequency distribution of wind direction, wind speed, and atmospheric stability used in this analysis for RFETS are presented in Bergenback et al. (1995).

\subsection{Savannah River Site}

The SRS is located in the southwestern portion of South Carolina, $\sim 20 \mathrm{~km}$ south of Aiken, South Carolina, and $40 \mathrm{~km}$ southeast of Augusta, Georgia (Figure 4.13). The installation occupies $800 \mathrm{~km}^{2}$, with $\sim 10 \%$ of the property being used to support facilities and operations (Arnett et al. 1993).

The SRS is located on the Upper Atlantic Coastal Plain, $\sim 32 \mathrm{~km}$ southeast of the Fall Line, which separates the Piedmont and Coastal Plain provinces. The site is located on the Aiken Plateau, a relatively flat area that slopes southeastward and is dissected by several tributaries of the Savannah River. The SRS is underlain by a 210 - to 370 -m-thick seaward-thickening wedge of Coastal Plain sediments composed of Cretaceous to post-Eocene-aged unconsolidated sands, clayey sands, sandy clays, and lesser amounts of calcareous sediment. The sediments at the SRS constitute a multilayer hydrogeologic system in which there are clay-rich confining units partially or totally isolating transmissive zones of interbedded sand and sandy clay.

Three major water-bearing zones in the Coastal Plain sediments are divided by regional aquitards. In ascending order, these are the Cretaceous zone, the lower Eocene Congaree-Fourmile zone, and the middle to post-Eocene upper saturated zone (Arnett et al. 1993). The deepest aquifer monitored at the SRS occurs in Cretaceous-aged sediments. Overlying and separating the deepest zone from the intermediate Congaree-Fourmile aquifer is a Paleocene-aged regional aquitard. The intermediate aquifer is an important local source of groundwater. A local aquitard, referred to as the "Green Clay," overlies the intermediate aquifer, separating it from the upper saturated zone. Sediments of the upper saturated zone.generally yield low amounts of water, occurring predominantly in sandy clays and calcareous sediments of middle to late-Eocene and post-Eocene age. Numerous, discontinuous, clay-rich layers 


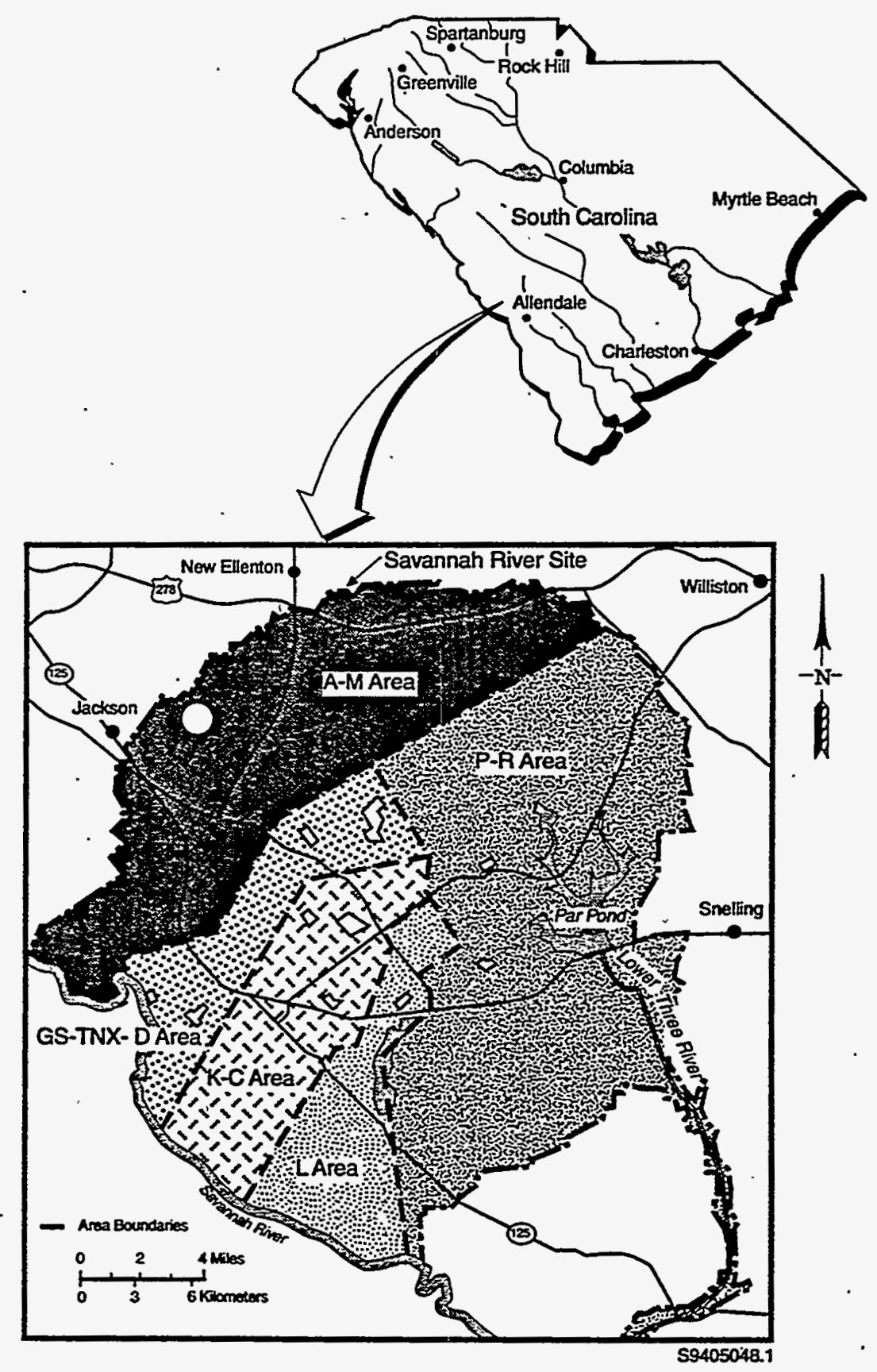

Figure 4.13. Location and Environmental Settings for the Savannah River Site (SRS). For modeling purposes, the SRS is divided into five environmental settings: A-M, P-R, GS-TNX-D, K-C, and L areas. 
act as local aquitards, creating groundwater-flow patterns at the SRS, which are locally complex. Few of these aquitards are continuous across the SRS (Arnett et al. 1993).

Groundwater-flow direction at the SRS is typically controlled by the streams on the Aiken Plateau. Groundwater in the deep Cretaceous zone flows toward and discharges into the Savannah River. Groundwater in the intermediate Congaree-Fourmile aquifer flows toward and discharges into either Upper Three Runs Creek or the Savannah River, with the closer channel having the greatest influence. Groundwater in the upper saturated zone flows toward and discharges into the nearest perennial stream, swamp, or river. Local flow patterns may be very complex; nevertheless, all groundwater in these zones eventually exits the subsurface and flows from springs or streams into the Savannah River (Amett et al. 1993).

The SRS is bounded on its southwestern boundary by the Savannah River for $\sim 32 \mathrm{~km}, \sim 260 \mathrm{~km}$ upriver from the Atlantic Ocean. Five major streams at the SRS feed into the Savannah River: Upper Three Runs Creek, Four Mile Creek, Pen Branch, Steel Creek, and Lower Three Runs Creek. Other surfacewater bodies at the site that feed into the five streams include PAR Pond, L Lake, Tims Branch, Tinker Creek, and Meyers Branch (Arnett et al. 1993). In all but one of the environmental settings developed for the SRS (the P-R Area setting), surface and subsurface drainage from both upland and lowland areas flows into creeks flowing southward into the Savannah River.

\subsubsection{TRU Waste Storage}

The TRU waste at the SRS is in retrievable storage on concrete pads or buried in shallow trenches. The waste is contained in concrete and steel boxes, concrete culverts, and galvanized steel drums covered with $1.2 \mathrm{~m}$ of soil or tornado netting (in use since 1985).

The 1.2-m soil cover would be removed from the stored waste pads by earth-moving equipment to within 15 to $30 \mathrm{~cm}$ of the waste containers. The remaining soil would be removed with the remotely operated, high-efficiency particulate-air (HEPA) filtered soil vacuum. Drums would be removed using a shielded lifting canister. Large steel boxes and concrete culverts would be lifted from the pads and placed directly on a transport trailer for shipment to the TRU Waste Processing Facility building.

\subsubsection{Local Environmental Setting}

For purposes of this analysis, TRU wastes were assumed to be stored in the GS-TNX-D Area setting (see Figure 4.13); one of the five hydrogeologic environmental settings used to represent the SRS in Holdren et al. (1995). Figure 4.14 presents stratigraphic columns for each of these settings. Hydrogeologic data for the various settings are presented in Holdren et al. (1995, Tables 25.1 through 25.4). A brief description of the hydrogeology of the GS-TNX-D Area setting for SRS is as follows.

Setting descriptions for GS-TNX-D, K-C, and L Area settings are nearly identical to the A-M Area setting, with the exception of groundwater-flow direction and discharge within each specific area. More than a fourth of the SRS falls within the A-M Area setting, with the Pleistocene terraces 

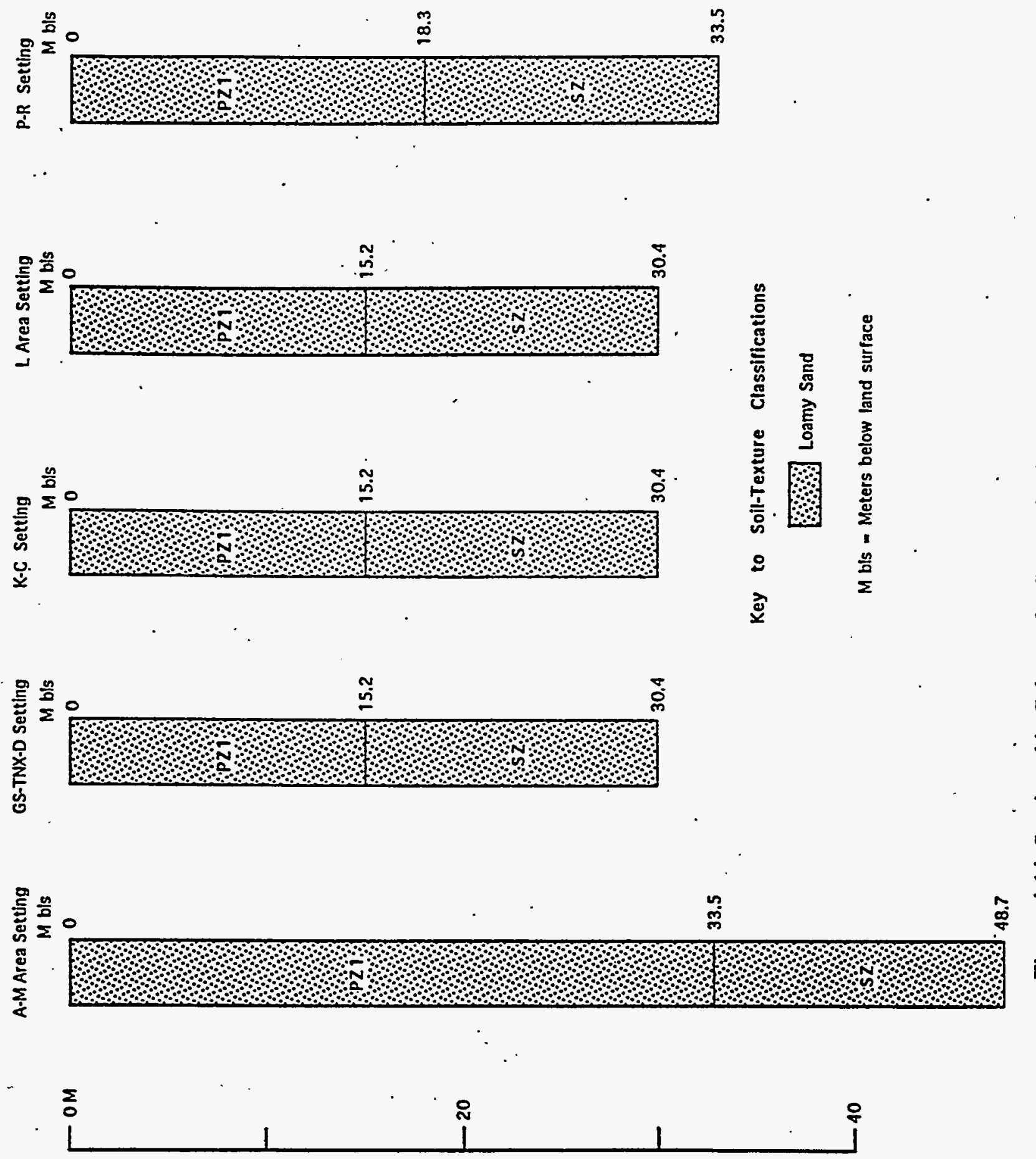
occupying the southwestern quarter of the setting's area. Shallow groundwater in this setting discharges to the Upper Three Runs and Tinker creeks at springs and seeps along their margins.

The units of interest are limited to the saturated zone and uppermost aquifer. The thickness of the saturated zone averages $34 \mathrm{~m}$, with maximum thicknesses reaching more than $46 \mathrm{~m}$ at higher elevations. The upper aquifer averages $15 \mathrm{~m}$ in the A-M Area, but may be as thick as $46 \mathrm{~m}$. A total porosity value of $40 \%$ and an effective porosity of $25 \%$ were used for the A-M Area setting. The vertical hydraulic conductivity of the saturated zone is estimated at $1.0 \mathrm{E}-04 \mathrm{~cm} / \mathrm{s}$. Hydraulic gradient ranges from 0.016 to 0.002 , based on measurements from a 1993 water-table map. The effective porosity value, hydraulic conductivity, and hydraulic gradient were used to calculate the groundwaterflow velocity, which ranged from $3.0 \mathrm{E}-05$ to $3.3 \mathrm{E}-06 \mathrm{~m} / \mathrm{d}$. The remaining values for the A-M Area setting are based on default values for the soil types. This setting description will focus on items unique to the individual areas, as well as information pertaining to all three areas.

Pleistocene terraces occupy the southwestern third of the GS-TNX-D Area, and the Aiken Plateau occupies the upland two thirds of this setting. Water in the shallow aquifer flows northward from all three operation units and discharges to Upper Three Runs Creek. There is also a component of southward flow to Four Mile Creek. Discharge is at springs and seeps along the creek margins.

The meteorological and atmospheric dispersion data in the form of a joint-frequency distribution of wind direction, wind speed, and atmospheric stability used in this analysis of SRS are presented in Bergenback et al. (1995). 



\subsection{Waste Characteristics}

To model the health effects associated with TRU waste at the various sites, the waste must be characterized in terms of its volume, amount of contaminant, and form. This chapter describes the different TRU waste forms modeled and the methods used to determine TRU waste volumes and contaminant inventories for each waste form at the different generator/storage sites.

\subsection{Introduction}

TRU wastes analyzed in the FEIS (DOE 1980) and SEIS-I (DOE 1990) included wastes placed in retrievable storage. TRU wastes that were expected to be generated by ongoing defense activities and programs were also analyzed. The No Action Alternative 2 analysis also needed to deal with wastes in retrievable storage and those expected to be generated, but major changes in information and assumptions regarding TRU wastes have occurred since the completion of SEIS-I. These changes include:

- Additional sites that have, or expect to generate, TRU waste have been identified. TRU waste volumes at these sites, however, account for only a small percent of the total TRU waste volume.

- Estimates of the future generation of TRU waste differ for some sites because of changes in mission.

- More detailed descriptions of the volume and physical characteristics of waste streams have been developed at many sites.

- More detailed descriptions of the radionuclide content of waste streams have been developed at many sites.

The information for the updated waste characteristics were taken from four main data sources: DOE 1994, 1995b, 1995c, 1996 b.

The database in Baseline Inventory Report, Revision 2 (BIR-2) (DOE 1995b) contains detailed physical descriptions of TRU waste, as well as TRU waste volumes and radionuclide inventories associated with individual waste streams at generator/storage sites. The database contains both stored TRU waste volumes and TRU waste volumes expected to be generated through the year 2022 .

Where possible, BIR-2 (DOE 1995b) was used as the information source for the radionuclide inventories. However, the primary source of radionuclide inventory data was that reported in DOE (1994).

The inventory of hazardous constituents was estimated from DOE (1995b, 1995c, 1996b). 


\subsection{Waste Volumes}

BIR-2 (DOE 1995b) contains detailed information on TRU waste currently in retrievable storage . (the stored volume) and TRU waste expected to be generated in the next 28 years (the projected volume). Conservative volume analyses are based on an upper TRU waste-generation limit taken from BIR-2.

It is assumed that WIPP operations begin in 1998 and continue for 35 years, ending TRU wastereceipt operations in 2033. Projected TRU waste volumes $\left(V_{\text {projected }}\right)$ are given in BIR-2; however, these values reflect volumes estimated in the year 2022. To estimate the total TRU waste-inventory volume at a generator/storage site in 2033 , the following calculation was used:

$$
V_{\text {site }}=V_{\text {stored }}+\left[38\left(R_{\text {generate }}\right)\right]
$$

where $V_{\text {site }}=$ estimated TRU waste volume through the year 2033 (cubic meters)

$\mathrm{V}_{\text {stored }}=$ TRU waste volume stored at the generator/storage site in 1995 (cubic meters)

38 = number of years of waste generation (35 plus 3 years until 1998)

$R_{\text {generate }}=\left(V_{\text {projected }}\right) / 28$ years; and is the TRU waste-volume-generation rate (cubic meters per year).

Application of the previous assumptions gives a total estimated TRU waste volume of $143,000 \mathrm{~m}^{3}$ for $\mathrm{CH}$ TRU waste and $35,000 \mathrm{~m}^{3}$ for RH TRU waste. TRU waste volumes for each of the 10 major generator/storage sites, projected to the year 2033, are given in Table 5.1.

Table 5.1. TRU Waste Volumes for No Action Alternative $2^{(a)}$

\begin{tabular}{|c|c|c|c|c|c|c|}
\hline \multirow[b]{2}{*}{ Site } & \multicolumn{2}{|c|}{$\begin{array}{c}\text { Site Volume } \\
\text { Through } 2033\left(\mathrm{~m}^{3}\right)\end{array}$} & \multicolumn{2}{|c|}{$\begin{array}{c}\text { Existing Stored } \\
\text { Volume }\left(\mathrm{m}^{3}\right)\end{array}$} & \multicolumn{2}{|c|}{$\begin{array}{l}\text { Newly Generated } \\
\text { Yolume }\left(\mathrm{m}^{3}\right)\end{array}$} \\
\hline & CH & $\mathbf{R H}$ & $\mathbf{C H}$ & $\mathbf{R H}$ & CH & RH \\
\hline Argonne National Laboratory-East & 200 & - & 25 & - & 180 & - \\
\hline Hanford Site & 57,490 & 29,420 & 12,300 & 200 & 45,190 & 29,200 \\
\hline Idaho National Engineering Laboratory ${ }^{(0)}$ & 29,160 & 1,960 & 28,155 & 240 & 1,005 & 1,720 \\
\hline Lawrence Livermore National Laboratory & 1,200 & - & 230 & - & 960 & - \\
\hline Los Alamos National Laboratory & 21,000 & 230 & 11,050 & 90 & 9,980 & 130 \\
\hline Mound Plant & 300 & - & 300 & $-\cdot$ & - & - \\
\hline Nevada Test Site & 630 & - & 620 & - & 10 & - \\
\hline Oak Ridge National Laboratory. & 1,670 & 3,080 & 1,320 & 2,470 & 350 & 600 \\
\hline Rocky Flats Environmental Technology Site & 10,860 & - & 4,890 & - & 5,970 & - \\
\hline Savannah River Site & 12,070 & - & 2,880 . & - & 9,180 & - \\
\hline
\end{tabular}


Although these volumes are based on updated/improved data, there are still some uncertainties and inconsistencies associated with the numbers. These are mainly related to decontamination and decommissioning (D\&D)/environmental restoration (ER) activities and Hanford's suspect RH TRU waste. DOE is developing D\&D and ER inventories through the 1995 baseline environmental management report data call. However, only Hanford-reported D\&D and ER projections were available in time to be included in the BIR-2 (DOE 1995b).

Estimates of Hanford suspect waste also varied greatly. Revision 1 of BIR reported Hanford's submittal as $\sim 46,000 \mathrm{~m}^{3}$ of projected RH TRU waste, of which $43,000 \mathrm{~m}^{3}$ were called "suspect" $\mathrm{RH}$ TRU waste because of insufficient information. Reevaluation of the $46,000 \mathrm{~m}^{3}$ of projected RH TRU waste by Hanford personnel resulted in a decrease of the reported projected RH TRU waste to $\sim 21,500 \mathrm{~m}^{3}$ (through the year 2022) for BIR-2 (DOE 1995b). Additional evaluations of the reported Hanford RH TRU waste volumes are ongoing, and the results will be reported in future revisions of the BIR. Hanford now reports $\sim 200 \mathrm{~m}^{3}$ of stored RH TRU wastes, with the rest of the waste still to be generated.

\subsection{Contaminant Inventories}

To conduct risk analyses, it is necessary to know the contaminant inventories at each site. After reviewing available data, contaminants were categorized into radionuclides, organics, and inorganic metals. The contaminant inventories in each of these categories are described below.

\subsubsection{Radionuclides}

The radionuclide activity for the 10 major generator/storage sites was obtained primarily from DOE (1994). More than $99 \%$ of the CH TRU stored waste volume and $94 \%$ of the RH TRU stored waste volume are located at these major sites.

The radionuclide inventories for stored $\mathrm{CH}$ and $\mathrm{RH}$ TRU waste adjusted for decay to December 31 , 1995, according to major generator/storage site, are given in Tables A.1 and A.2, respectively. Note that information from the BIR-2 (DOE 1995b) was used as a source for the RFETS residue data. TRU inventories at RFETS were assumed to include the residue inventories.

Two additional steps were required to determine the initial radioactive inventories for No Action Alternative 2. First, the inventories had to be adjusted to account for the newly generated volume. This was done using Equation (5.2) that can be rearranged to Equation (5.3) to establish a $V_{\text {factor. }}$. The December 31,1995 inventory is multiplied by this factor to account for the newly generated volume.

$$
I_{\text {No-Act_Alt.2 }}=I_{1995}+\left(\frac{I_{1995}}{V_{\text {Stored }}}\right)\left(V_{\text {Estimated }} \cdot V_{\text {Stored }}\right)
$$


where $\mathrm{I}_{\mathrm{No} \text {-Act.Alt.2 }}=$ total site radionuclide inventory (in curies)

$I_{1995}=$ inventory corrected to December 31,1995 (in curies)

$\mathrm{V}_{\text {estimated }}=$ estimated total volume to be generated through 2033 (see Table 5.1) (cubic meters)

$\mathrm{V}_{\text {stored }}=$ existing stored volume (see Table 5.1). (cubic meters)

Rearranging terms, this equation can be written as:

$$
\begin{gathered}
I_{\text {No-Act.Alt.2 }}=I_{1995}\left[1+\left(\frac{v_{\text {estimated }}-v_{\text {stored }}}{V_{\text {stored }}}\right)\right] \\
\text { or } \\
I_{\text {No-Act.Alt.2 }}=I_{1995} V_{\text {factor }}
\end{gathered}
$$

where $\quad V_{\text {factor }}=$ complex volume variable used to estimate the total site radionuclide inventory for each alternative (unitless).

CH TRU waste-volume factors $\left(V_{\text {Factor }}\right)$ are presented in Table 5.2. Table 5.3 gives RH TRU wastevolume factors according to site.

The next step is to account for radioactive decay that occurred prior to the start of the analysis. No Action Alternative 2 long-term performance calculations are initiated at the assumed time of loss of

Table 5.2. Volume Factors Used to Estimate Total CH TRU Radionuclide Inventories at Major Sites ${ }^{(a)}$

\begin{tabular}{|l|c|}
\hline \multicolumn{1}{|c|}{ Site } & No Action Alternative 2 \\
\hline Argonne National Laboratory-East & 8.111 \\
\hline Hanford Site & 4.673 \\
\hline Idaho National Engineering Laboratory & 1.000 \\
\hline Lawrence Livermore National Laboratory & 5.186 \\
\hline Los Alamos National Laboratory & 1.903 \\
\hline Mound Plant & 1.000 \\
\hline Nevada Test Site & 1.020 \\
\hline Oak Ridge National Laboratory & 1.263 \\
\hline Rocky Flats Environmental Technology Site ${ }^{\text {(b) }}$ & 9.462 \\
\hline Savannah River Site & 1.998 \\
\hline $\begin{array}{l}\text { (a) Volume factors are used in Equation (5.3). } \\
\text { (b) RFETS residue data are not included in the volume factors. } \\
\text { (c) Volume of 9,200 } \mathrm{m}^{3} \text { used for SRS. }\end{array}$ \\
\hline
\end{tabular}


Table 5.3. Volume Factors Used to Estimate Total RH TRU Radionuclide Inventories at Major Sites ${ }^{(2)}$

\begin{tabular}{|l|c|}
\hline \multicolumn{1}{|c|}{ Site } & No Action Alternative 2 \\
\hline Hanford Site & 150.708 \\
\hline Idaho National Engineering Laboratory & 3.009 \\
\hline Los Alamos National Laboratory & 3.677 \\
\hline Oak Ridge National Laboratory & 1.292 \\
\hline (a) Volume factors are used in Equation 5.3. \\
\hline
\end{tabular}

institutional control at the generator/storage sites. This is assumed to be $100 \mathrm{yr}$ after the closure of WIPP (in the year 2133). The CH and RH TRU waste radionuclide inventories decayed to the year 2133 are given Tables A.3 and A.4. Only those radionuclides with activities greater than $1 \mathrm{Ci}$ and half-lives greater than $10 \mathrm{~min}$ have been retained.

\subsubsection{Organics}

Other than to indicate the presence of a relatively small volume of polychlorinated biphenyl (PCB)commingled waste, the BIR-2 database (DOE 1995b) does not contain information on organic compounds. In fact, very little direct organic inventory data are available. Therefore, head-space data in the Comment Responses and Revisions to the Resource Conservation and Recovery Act Part B Permit Application was used to estimate concentrations of volatile organic compounds (DOE 1996, Table C.2-4). The permit application summarizes the results of a head-space-sampling and -analysis study conducted on RFETS CH TRU waste. Approximately 930 drums of varying waste types were sampled. The average concentrations of the volatile organic compounds established for each wasteform type are shown in Table A.5. (See Section 5.5 for description of waste-form types.) Where compounds were not detected in the sampling process, one half of the detection limit was used for calculating average concentrations.

Waste-form data (in Section 5.5) were combined with the head-space-concentration data to establish the volume-weighted average concentrations for $\mathrm{CH}$ wastes shown in Table A.6. The sampling data in DOE (1996b) were taken from drums containing CH TRU waste. In the absence of further information, the same concentrations were assumed to apply to RH TRU waste. The weighted average concentrations by site for RH TRU waste for No Action Alternative 2 are given in Table A.7.

For analyses that require total inventory, head-space data were used to calculate a total inventory of organic contaminants. Rault's Law and the assumption that the maximum average quantity of organic liquid in TRU waste is 1-weight percent were used. The calculated volatile organic compound inventories for both $\mathrm{CH}$ and RH TRU waste according to site are shown in Tables A.8 and A.9. 


\subsubsection{Inorganic Metals}

BIR-2 (DOE 1995b) does not contain detailed information on hazardous constituents. An inventory of hazardous metals, however, was developed for fire and explosion accident scenarios in DOE (1995c, Table 5.9). These inventory values, which correspond to a $110-\mathrm{kg}$ drum, are $0.023 \mathrm{~kg}$ for beryllium; $3.3 \mathrm{E}-04 \mathrm{~kg}$ for cadmium; $0.91 \mathrm{~kg}$ for lead; and $0.39 \mathrm{~kg}$ for mercury.

Using the average material parameter data in BIR-2, a drum of CH TRU waste is expected to contain $-120 \mathrm{~kg}$ of waste. Similarly, a drum of RH TRU waste is expected to contain $105 \mathrm{~kg}$ of waste. CH TRU metal concentrations were scaled up from the $110-\mathrm{kg}$ drum in DOE (1995c) to the $120-\mathrm{kg}$ drum in this analysis. Similarly, the RH TRU metal concentrations were scaled down to the $105-\mathrm{kg}$ drum. The BIR-2 lead inventory value of $464 \mathrm{~kg} / \mathrm{m}^{3}$, which includes lead for shielding, was used for the RH TRU concentration. Concentrations of metals used in the analyses for both CH TRU and RH TRU waste are listed in Table.A.10.

Total inventory values for hazardous metals for each of the analyzed sites are given in Table A.11. These values are based on the metal concentrations in Table A.10 and volume data in Table 5.1.

\subsection{Description of TRU Waste Forms and TRU Waste-Form Categories}

TRU waste-form characteristics can have large effects on the rate at which contaminants are released from the waste zone. The characteristics of the TRU waste forms at the sites vary widely but can be classified into one of two general waste-form categories. These categories and the modeling parameters associated with each are discussed below.

The first general waste-form category comprises permeable, unconsolidated wastes. All surfaces are exposed to uncontaminated water as it percolates through the site. Because the waste zone is unconsolidated material, it is also susceptible to wind-suspension and water-erosion processes. The release of contamination by leaching is regulated by the relative tendency of the contaminants to exist in either an aqueous phase or sorbed to solid surfaces. This partitioning between aqueous and adsorbed phases is often expressed in terms of a surface-adsorption coefficient, $\mathrm{K}_{d}$, and is dependent on the contaminant and the solid adsorbent material. If a contaminant is present in high enough concentrations, the capacities of the aqueous and sorbed phases to contain the contaminant can be exceeded. Contaminant release, therefore, will be controlled by its solubility.

The permeable TRU waste forms in this category can be further subdivided into those having either low or high surface-area-to-volume ratios. Examples of TRU waste forms with low surface-area-tovolume ratios and relatively low-surface-adsorption coefficients include waste containers, personal protective equipment, and metal process equipment. Contaminants from this type of TRU waste form readily leach into the surrounding soil. Their release from the waste zone is controlled by the sorptive properties of the surrounding soil. 
TRU wastes with high surface-area-to-volume ratios can have high-surface-adsorption coefficients. Contaminant release from these TRU waste forms may be controlled by the sorptive properties of the TRU waste form itself. Examples of high-surface-area wastes include sludge, soil, and spent filters/ adsorbents. Although the TRU waste form may control the release rate, physical data available for these waste types are limited, making it difficult to estimate sorption coefficients. It is conservatively assumed, therefore, that the sorptive properties of the surrounding soil can also be used to determine the release characteristics of the high-surface-area TRU waste forms.

The second general waste-form category comprises solidified TRU waste forms whose permeability is much lower than that of the surrounding soil while sufficiently high to allow significant contaminant mobility within the TRU waste form. Percolating water tends to move around these TRU waste forms and leach contaminants only from their exterior surface. The most common example of this TRU waste form is cemented waste. As contaminants are removed from the exterior surface, concentration gradients are established and contaminants tend to diffuse from the interior of the waste to the exterior surface. Therefore, the contaminant-release rate depends on the internal mobility of the contaminant, which is often expressed as an effective contaminant-diffusion coefficient. Wind suspension and water erosion are assumed to not affect this solidified waste-form category until the TRU waste form fails.

In addition to contaminant-specific diffusion coefficients, the surface-area-to-volume ratio of the TRU waste form is required to model the release of contamination. It was assumed that waste will be disposed of in $208-\mathrm{L}$ drums ( $-91.4 \mathrm{~cm}$ tall and $66 \mathrm{~cm}$ in diameter), and that a cement slurry is poured directly into the drum, completely filling it. Using these assumptions, a surface-area-to-volume ratio of $0.082 \mathrm{~cm}^{-1}$ was calculated.

Another important parameter required for modeling contaminant release from this TRU waste-form category is the effective lifetime of the form. Cement degrades over time and will crack into small pieces such that the release of contamination is no longer limited to surface diffusion. At this point, contaminant release will be controlled more by surface adsorption and desorption than by diffusion. The effective lifetime of the TRU waste form depends on various properties of the cement, including the type of solidification agent used, solidification agent-to-waste-to-water ratios, curing conditions, waste composition, and storage environment conditions, such as the number of wet/dry and freeze/thaw cycles. An effective lifetime of $500 \mathrm{yr}$ was used for cemented TRU waste forms in this analysis.

\subsection{Quantity of Each TRU Waste-Form Category}

The relative quantities of each TRU waste-form category at a site were determined using information available in BIR-2 (DOE 1995b). BIR-2 specifies a waste volume and waste density for each of 11 waste-material types (Table 5.4). These waste-material types were categorized into one of the general TRU waste-form categories modeled in this analysis. 
Table 5.4. Final TRU Waste Form Definitions

\begin{tabular}{|c|c|c|}
\hline $\begin{array}{l}\text { Final TRU Waste } \\
\text { Form }\end{array}$ & Definition & $\begin{array}{l}\text { Waste-Form } \\
\text { Category }\end{array}$ \\
\hline Combustible & $\begin{array}{l}\text { Debris that is } \sim 95 \% \text { or more, by volume, combustible materials. Examples of } \\
\text { combustible debris are materials constructed of plastic, rubber, wood, paper, and } \\
\text { cloth. }\end{array}$ & Soil/debris \\
\hline Filter & $\begin{array}{l}\text { Debris that is }-50 \% \text { or more, by volume, high-efficiency particulate-air (HEPA) } \\
\text { filters or additional filters constructed or more than one material type (e.g., metal, } \\
\text { inorganic nonmetal, and combustibles). }\end{array}$ & Soil/debris \\
\hline Graphite & $\begin{array}{l}\text { Debris that is }-95 \% \text { or more, by volume, graphite-based solid materials, Graphite } \\
\text { debris includes crucibles, graphite components, and pure graphite. }\end{array}$ & Soil/debris \\
\hline Heterogeneous & $\begin{array}{l}\text { Debris that is at least } 50 \% \text {, by volume, materials that do not meet criteria for } \\
\text { assignment into other categories. For example, waste that is a mixture of metal and } \\
\text { combustible debris, neither of which comprises } 9 \% \text { or more, by volume, of the } \\
\text { waste. }\end{array}$ & Soil/debris \\
\hline Inorganic nonmetal & $\begin{array}{l}\text { Debris that is }-95 \% \text { or more, by volume, inorganic nonmetal material. Examples of } \\
\text { waste in this group include glass and ceramics. }\end{array}$ & Soil/debris \\
\hline Lead/cadmium metal & $\begin{array}{l}\text { Debris that is } \sim 95 \% \text { or more, by volume, metal that contains bulk lead or cadmium } \\
\text { as part of the matrix. Examples of this waste include glovebox parts with lead clad } \\
\text { in stainless-steel or cadmium sheets. }\end{array}$ & Soil/debris \\
\hline Uncategroized metal & $\begin{array}{l}\text { Debris that is }-95 \% \text { or more, by volume, metal but either lacks sufficient } \\
\text { information to enable characterization into one of the other categories or contains } \\
\text { both lead and cadmium as part of the bulk matrix. }\end{array}$ & Soil/debris \\
\hline Salt & $\begin{array}{l}\text { Debris that is at least } 50 \% \text { by volume, salts. Stable pyrochemcial salt is an example } \\
\text { of this group. }\end{array}$ & Soil/debris \\
\hline Soil & $\begin{array}{l}\text { Debris that is } ~-95 \% \text { or more, by volume, soil. This includes sand, silt, and } \\
\text { rock/gravel, where rock/gravel volumes total }<50 \% \text { of the matrix }\end{array}$ & Soil/debris . \\
\hline Solidified inorganic & $\begin{array}{l}\text { Debris that is at least } 50 \% \text { by volume, inorganic process residues. This group } \\
\text { includes solidified sludges and particulates. }\end{array}$ & Cement \\
\hline Solidified organic & $\begin{array}{l}\text { Debris that is at least } 50 \% \text { by volume, organic process residues. These are defined as } \\
\text { process residues with a base structure that is primarily organic. The matrix may } \\
\text { : contain some inorganic solids content such that } \sim 20 \% \text { by weight, of the waste } \\
\text { would remain as residue ash/solids content such that }-20 \% \text { by weight, of the waste } \\
\text { would remain as residue ash/solids following incineration. Examples include } \\
\text { organic resins, organic sludges and solidified organic liquids. }\end{array}$ & Cement \\
\hline
\end{tabular}

The total mass of each TRU waste-material type at each site was calculated by adding the product of the waste volume and the waste density for each waste stream (Tables C.1 and C.2). The total mass of all TRU waste material was used to determine the weight percent of each type of waste material at the various sites.

$\mathrm{CH}$ and RH TRU waste masses for the different waste-material types within a general category were combined to determine the relative weight percent for each general TRU waste-form category. 
The densities of both TRU waste forms were assumed to be equal, so that the weight-percent analysis could be applied directly to the total waste volume.

For this analysis, TRU waste would be located in Hanford's 200-West and 200-East areas. Because the distribution between the two Hanford areas is not currently known, it was assumed that $50 \%$ of the total volume would be disposed of at each Hanford location. The final relative percentages for each general TRU waste-form category at each release site are shown in Table 5.5. These relative quantities were multiplied by the total TRU waste volumes for the site (see Table 5.1) to determine final site volumes for each TRU waste-form category. Volumes are also reported in Table 5.5.

\subsection{Contaminant Inventory Distribution over Different TRU Waste-Form Categories}

The radioactive and hazardous contaminant inventories used in this analysis are the total inventories present at each site for both $\mathrm{CH}$ and $\mathrm{RH}$ waste. The contaminant inventory data were not consistantly categorized by TRU waste-material type. Therefore, for analysis purposes, the $\mathrm{CH}$ and RH TRU waste inventories are added together and assumed to be distributed over the different TRU waste-form categories with the same relative ratios as the volume fractions. For example, if a site has $75 \%$ soil/debris and $25 \%$ cemented TRU waste volume, the contaminant inventory was distributed $75 \%$ to soil/debris and $25 \%$ to cement.

Table 5.5. Relative Quantities and Volumes of Each Waste-Form Category by Release Site

\begin{tabular}{|l|c|r|r|r|}
\hline \multirow{2}{*}{ Release Site } & \multicolumn{2}{|c|}{ Relative Quantity (\%) } & \multicolumn{2}{c|}{ Volume $\left(\mathbf{m}^{3}\right)$} \\
\cline { 2 - 5 } & Soil/Debris & Cement & Soil/Debris & Cement \\
\hline Hanford 200E & 100.0 & 0.0 & 43,500 & 0 \\
\hline Hanford 200W & 100.0 & 0.0 & 43,500 & 0 \\
\hline INEL & 84.3 & 15.7 & 26,200 & 4,890 \\
\hline LANL & 63.8 & 36.2 & 13,600 & 7,700 \\
\hline LLNL & 97.4 & 2.6 & 1,160 & 31 \\
\hline ORNL & 76.1 & 23.9 & 4,200 & 1,320 \\
\hline RFETS & 77.6 & 22.4 & 8,340 & 2,430 \\
\hline SRS & 85.2 & 14.8 & 10,300 & 1,790 \\
\hline
\end{tabular}




\subsection{Waste Configuration and Contaminant-Release Scenarios}

This chapter describes the assumptions used in the source-term-release analysis, which provides the contaminant-flux factors in the MRA methodology approach. Topics include a general conceptual sitemodel for buried and surface-stored TRU waste, assumptions governing the release of contaminants from the TRU waste-form categories, contaminants of concern (COCs) considered in this analysis, and example outputs resulting from source-term-release calculations.

\subsection{Conceptual Model for Contaminant Release Scenarios}

The overall geometric configuration of the waste-storage zone, the assumed degradation of the waste-storage zone, and how the distribution of the TRU waste forms within the zone affect the magnitude and areal extent of the contaminant-release fluxes from the zone are discussed below.

\subsubsection{Waste-Storage Configuration}

The following assumptions were made for the analysis of buried TRU waste: 1) all TRU waste is contained in 208-L drums ( $-91.4 \mathrm{~cm}$ tall) that are stored together in one shallow burial zone; 2 ) four layers of drums are stacked on an asphalt or concrete pad, with plywood sheets between the layers and on top; and 3) $1.2 \mathrm{~m}$ of contaminant-free soil are backfilled over the layers of drums. This overall configuration is illustrated in Figure 6.1.

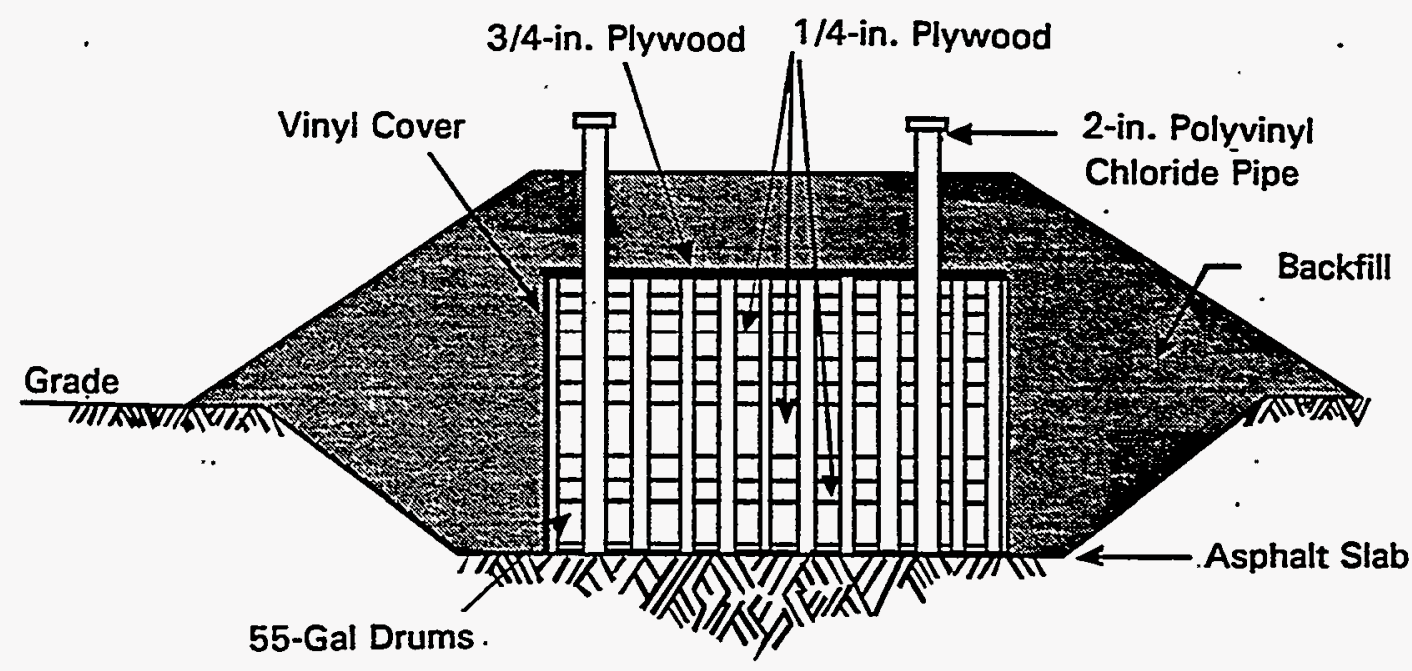

Figure 6.1. Overall Configuration of the Buried Waste-Storage Zone 
For the analysis of surface-stored TRU waste, the initial waste-zone configuration is similar to that for buried TRU waste. It is assumed that four layers of drums are stacked on an asphalt or concrete pad, with plywood sheets between the layers and on top. The stacked drums are placed in metal storage buildings, instead of being buried. This overall configuration is illustrated in Figure 6.2.

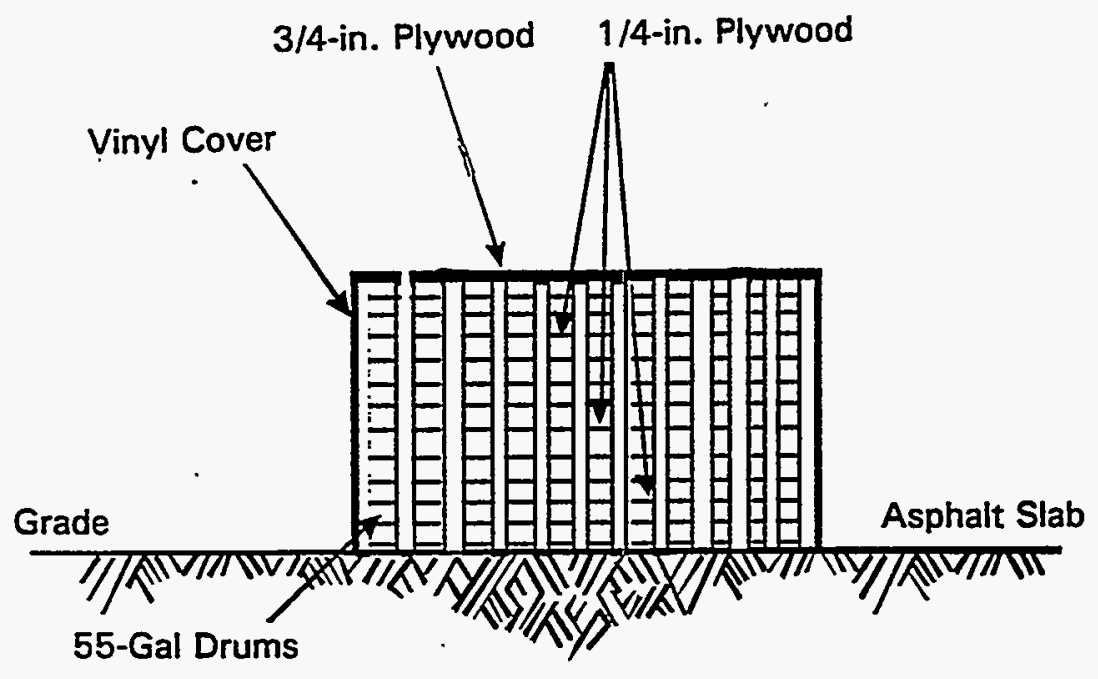

Figure 6.2. Overall Configuration of the Surface Waste-Storage Zone

The vertical dimension of the waste zone for both buried and surface-stored configurations is approximately equal to $3.7 \mathrm{~m}$. The drums are placed as closely to one another as is possible in a rectangular grid arrangement. Because of this configuration, the volume of the waste zone will be larger than the volume of the TRU waste itself. The ratio of waste-zone and waste-drum volumes for a rectangular grid arrangement is:

$$
\left[N(2 r)^{2}(4 h) /\left(N \pi r^{2}(4 h)\right]=4 / \pi\right.
$$

where $\mathbf{N}=$ number of drums

$r=$ drum radius

$\mathrm{h}=$ drum height.

Waste-zone volumes for each TRU waste-form category are calculated for each site by multiplying the corresponding volumes reported in Table 5.5 by $4 / \pi$. These overall waste-zone volumes are reported in Table 6.1. The horizontal cross-sectional areas of each TRU waste-form category for each site can be calculated by dividing the waste-zone volumes by $3.7 \mathrm{~m}$. These areas along with the relative amounts of buried and surface stored waste for each site are also shown in Table 6.1. 
Table 6.1. Overall Waste-Zone Volumes and Horizontal Areas for each Waste-Form Category by Release Site

\begin{tabular}{|c|r|r|r|r|r|r|}
\hline \multirow{2}{*}{ Release Site } & \multicolumn{2}{|c|}{ Volume $\left(\mathbf{m}^{3}\right)$} & \multicolumn{2}{c|}{ Area $\left(\mathbf{m}^{2}\right)$} & \multicolumn{2}{c|}{ Zone Configuration (\%) } \\
\cline { 2 - 7 } & Soil/Debris & Cement & Soil/Debris & Cement & \multicolumn{1}{c|}{ Buried } & Surface \\
\hline Hanford 200E & 55,300 & 0 & 15,200 & 0 & 13.6 & 86.4 \\
\hline Hanford 200W & 55,300 & 0 & 15,200 & 0 & 13.6 & 86.4 \\
\hline INEL & 33,400 & 6,230 & 9,150 & 1,710 & 49.9 & 50.1 \\
\hline LANL & 17,300 & 9,800 & 4,740 & 2,690 & 37.9 & 62.1 \\
\hline LLNL & 1,480 & 39.7 & 406 & 10.9 & 0.0 & 100.0 \\
\hline ORNL & 5,350 & 1,680 & 1,470 & 460 & 15.2 & 84.8 \\
\hline RFETS & 10,700 & 3,090 & 2,940 & 848 & 0.0 & 100.0 \\
\hline SRS & 13,091 & 2,280 & 3,590 & 624 & 11.6 & 88.4 \\
\hline
\end{tabular}

\subsubsection{Assumed Degradation}

The ability of storage buildings, waste-configuration components, waste containers, and TRU waste forms to contain contaminants needs to be considered when modeling the long-term release of contaminants. The following discussion provides an overview of each of these considerations in terms of their effect on the long-term release of contaminants from TRU wastes.

\subsubsection{Facility}

The surface-storage scenario assumes that TRU waste is housed in metal storage buildings. These buildings will degrade relatively quickly over the 10,000 -yr evaluation period. This is chiefly due to the lack of maintenance after the loss of institutional control. Therefore, metal storage buildings and enclosures are assumed to offer no protection, and the surface-storage scenario is modeled as if the stacked waste drums were not sheltered for the entire evaluation period. Facility degradation is not applicable to the buried TRU waste scenario.

\subsubsection{Waste Configuration}

Components of the TRU waste-form configuration are assumed to degrade quickly relative to the 10,000-yr evaluation period. Degradation of the plywood or the storage building allows the spaces between the drums to fill with soil from the surface layer of the site. Likewise, once storage buildings degrade, the drums themselves will degrade at an accelerated rate, further altering the waste configuration. 
It is also assumed that the asphalt or concrete pad will be cracked or otherwise degraded for essentially the entire $10,000-y r$ evaluation period. This allows infiltrating water to percolate through the waste zone, pass through the cracked or degraded pad, and move through the remainder of the vadose zone directly beneath the waste zone.

\subsubsection{Waste Containers}

The integrity and longevity of the drums is also a factor in contaminant release from the waste zone. Both the surface-stored and buried scenarios assume that TRU waste will be contained in mild steel, U.S. Department of Transportation 17c drums. Corrosion rates for mild steel drums are quite high even when buried in favorable, dry environments. Drum lives of $<100 \mathrm{yr}$ are expected. Once the storage enclosure or building degrades to the point where waste drums are directly exposed to the elements, stored TRU waste drums are expected to degrade more rapidly than buried TRU waste drums. Because the expected life of the waste drums is relatively short compared to the $10,000-y r$ evaluation period, no credit was given for the presence of containers during the evaluation period in the analysis.

\subsubsection{Cemented TRU Waste Form}

Initially, the cemented TRU waste form is assumed to be a solid block having the same size and shape as a 208-L drum. Cemented monoliths are known to crack and degrade into porous material over time. Unfortunately, the theory for modeling the transition from a solid block to porous material and its effect on contaminant release is not well developed. It is assumed, therefore, that the cement waste blocks remain intact for the first $500 \mathrm{yr}$ and then catastrophically fail. After failure, the waste zone is assumed to act as a porous material.

\subsubsection{Distribution of TRU Waste Forms}

The horizontal cross-sectional area of the source zone is a required modeling input parameter. In reality, all drums of a given TRU waste-form category will not be emplaced in a single location within the waste zone. Rather, they will be interspersed with drums containing other TRU waste-form categories. To simplify the analysis, however, it is assumed that any specific areal location contains drums of only one TRU waste-form category over the four vertical layers. It is also assumed that the waste zone is composed of a random distribution of "reasonably large" subareas of drums of only one TRU waste-form category. Each subarea is of sufficient size so that contaminant release is controlled by the physics and chemistry of that subarea's TRU waste-form category alone. Therefore, contaminant release from the waste zone can be modeled in two parts (one for each waste-form category) using the conceptual mathematical models described in Chapter 2.0 and the appropriate fractional inventories and areas for each TRU waste-form category.

Contaminant mass flux is the output of source-term calculations for the subarea of each TRU wasteform category. Because the subareas are assumed to be uniformly dispersed throughout the waste 
zone, the mass flux of any contaminant from the two waste-form categories can be summed to determine the total mass flux of that contaminant over the cross-sectional area. Mass fluxes over the total waste-zone area are required inputs for subsequent transport simulations.

\subsection{Contaminant-Release Scenarios}

An overview of contaminant-release scenarios from the different TRU, waste forms for both the surface-stored and buried waste configurations follows. Geochemical controls that may limit the contaminant release from the overall waste zone are also discussed.

The overall rate of contaminant-mass loss from the waste zone is the sum of five different processes. These processes are decay, leaching, wind erosion, water erosion, and volatilization. The buried-waste scenario assumes a 1.2-m cover layer of soil that significantly reduces TRU waste interaction with surface-erosion/dispersion mechanisms. Leaching and decay, therefore, are the only two loss processes considered for the buried-waste scenario.

A "multimedia" scenario was used for surface-stored releases. Water erosion, wind suspension, and volatilization were considered in addition to leaching and decay. This scenario assumes that there is no cover layer and contaminant transport by water erosion and wind suspension begins at the start of. the analysis.

The effects of different TRU waste forms on each of the five different loss processes are discussed below.

\subsubsection{Soil/Debris TRU Waste Form}

The contaminant in soil/debris waste forms is assumed to be present either in the pore aqueous solution, in the pore vapor phase, or adsorbed to the porous medium particles. For radionuclides and metals, the contaminant may also be present in a solid phase (precipitates) if its inventory is higher than the capacity of the aqueous, vapor, and sorbed phases to contain it (i.e., solubility control). Similarly, for organic chemicals, the contaminant may also be present in an organic liquid phase (free product) if its inventory is higher than the capacity of the aqueous, vapor, and sorbed phases to contain it (i.e., solubility control). Unless this waste form is buried, all 5 loss processes can potentially occur.

Degradation/decay is assumed to be a first-order process. Therefore, the mass-flux equation for contaminant loss from the source zone by degradation/decay is given by:

$$
\left[\frac{d M_{i}}{d t}\right]_{d e c a y}=-\lambda_{i} M_{i}
$$


where $\left(\mathrm{dM}_{\mathrm{i}} / \mathrm{dt}\right)_{\text {decay }}=$ contaminant-mass loss rate resulting from decay for contaminant $\mathrm{i}(\mathrm{g} / \mathrm{yr}$ or $\mathrm{Ci} / \mathrm{yr}$ ).

$\mathrm{M}_{\mathrm{i}}=$ mass lost from decay for contaminant $\mathrm{i}$ (grams or curies).

$\mathrm{t}=$ time period of decay process (years).

$\lambda_{i}=$ first-order degradation/decay coefficient for contaminant $\mathrm{i}\left(\mathrm{yr}^{-1}\right)$.

When there is no solubility-controlled solid phase (for radionuclides and metals) or organic liquid phase (for organic chemicals) present, leaching loss of the contaminant is assumed to occur by desorption-controlled advective transport of the contaminant by previously clean water percolating through the porous waste. The waste zone is assumed to be a so-called "well-mixed reactor." Therefore, the mass-flux equation for contaminant release from the source zone by leaching in this instance is given by:

$$
\left[\frac{d M_{i}}{d t}\right]_{\text {leach }}=-\frac{U M_{i}}{\theta_{w} R_{w i}\left(h_{0}-d_{0}\right)}
$$

where $\left(\mathrm{dM}_{\mathrm{i}} / \mathrm{dt}\right)_{\text {leach }} \dot{=}$ contaminant-mass loss rate resulting from leaching for contaminant $\mathrm{i}(\mathrm{g} / \mathrm{yr}$ or $\mathrm{Ci} / \mathrm{yr})$.

$U=$ Darcy water-flux density of water infiltrating through the source zone $(\mathrm{cm} / \mathrm{yr})$

$\theta_{w} \cdot=$ volumetric water content of the soil (dimensionless)

$\mathrm{R}_{\mathrm{wi}}=$ standard retardation factor for contaminant $\mathrm{i}$ (dimensionless)

$h_{0}=$ initial distance from soil surface to bottom of the contaminant-source zone $(\mathrm{cm})$

$\mathrm{d}_{\mathrm{o}}=$ initial distance from soil surface to bottom of the clean soil layer (cm)

and retardation factor is defined by:

$$
\mathbf{R}_{\mathrm{wi}}=1+\frac{\beta}{\theta_{\mathrm{w}}} \mathbf{K}_{\mathrm{di}}
$$

where $\dot{B}=$ soil bulk density $\left(\mathrm{g} / \mathrm{cm}^{3}\right)$

$\mathrm{K}_{\mathrm{di}}=$ linear equilibrium sorption coefficient for contaminant $\mathrm{i}\left(\mathrm{cm}^{3} / \mathrm{g}\right)$. The contaminantspecific linear equilibrium sorption coefficient used in this analysis is given in Appendix B (Table B.3)

when a clean layer of soil exists on top of the waste zone, and is given by:

$$
\left[\frac{d M_{i}}{d t}\right]_{h e z c h}=-\frac{U M_{i}}{\theta_{w} R_{w i}\left[h_{0}-(E+S) t\right]}
$$


where $E=$ volumetric rate of soil removal by water erosion, per area $(\mathrm{cm} / \mathrm{yr})$

$\mathrm{S}=$ volumetric rate of soil removal by wind suspension, per area $(\mathrm{cm} / \mathrm{yr})$

when the waste zone is exposed to the atmosphere and water erosion and wind suspension are removing contaminated soil from the zone.

When the aqueous concentration of the contaminant is controlled by solubility, the mass-flux equation for contaminant loss from the source zone by leaching is given by:

$$
\left[\frac{d M_{i}}{d t}\right]_{l e z c h}=-U A C_{w i}
$$

where $A=$ horizontal cross-sectional area of the source zone $\left(\mathrm{cm}^{2}\right)$

$\mathrm{C}_{\mathrm{wi}}=$ concentration of contaminant $\mathrm{i}$ in the aqueous phase $\left(\mathrm{g} / \mathrm{cm}^{3}\right.$ or $\left.\mathrm{Ci} / \mathrm{cm}^{3}\right)$.

In this instance, $\mathrm{C}_{\mathrm{wi}}$ is just equal to the solubility if the contaminant is a radionuclide or metal. However, if the contaminant is an organic chemical (present in an organic liquid mixture), $C_{w i}$ is calculated by a more complicated algorithm that uses an analogue to Raoult's Law if the mole fraction of the contaminant in the liquid phase is close to one, ari analogue to Henry's Law (i.e., the octanolwater partition-coefficient concept) if the mole fraction of the contaminant in the liquid phase is close to zero, and a linear interpolation for the region in between.

Water erosion and wind suspension are assumed to strip soil particles from the soil surface at a constant rate. If these processes are stripping away clean soil above a waste zone, their associated contaminant mass-flux terms are equal to zero. If the waste zone is exposed to the atmosphere, the mass-flux equations for contaminant loss from the source zone by water erosion and wind suspension are given by:

$$
\left[\frac{d M_{i}}{d t}\right]_{\text {erosion }}=-\frac{E M_{i}}{h_{0}-(E+S) t}
$$

- where $\left(\mathrm{dM}_{\mathrm{i}} / \mathrm{dt}\right)_{\text {erosion }}=$ contaminant-mass loss rate resulting from water erosion for contaminant $\mathrm{i}$ (g/yr or $\mathrm{Ci} / \mathrm{yr})$

$$
\left[\frac{d M_{i}}{d t}\right]_{\text {suspension }}=-\frac{S M_{i}}{h_{0}-(E+S) t}
$$

where $\left(\mathrm{dM}_{\mathrm{i}} / \mathrm{dt}\right)_{\text {suspension }}=$ contaminant-mass loss rate resulting from wind suspension for contaminant $\mathrm{i}$ (g/yr or $\mathrm{Ci} / \mathrm{yr})$.

Volatilization losses of organic contaminants were assumed to be zero in the buried-waste scenario to establish a bounding case for groundwater contamination. In contrast, holes would readily develop 
in waste drums in the surface-stored scenario, causing most of the volatile organic inventory to be lost through volatilization. Therefore, the entire organic inventory is assumed to release through volatilization during the first year in the surface-stored scenario.

\subsubsection{Cemented Waste Forms}

For cemented waste forms, the distribution of contaminant between different phases within the porous cement is not accounted for explicitly in the theory. Decay and leaching are the only loss processes that are assumed to occur. Decay of the overall contaminant mass in the waste form is again assumed to occur according to Equation (6.2). Infiltration water percolating through the waste zone is . assumed to not penetrate the waste forms. Rather, leaching loss is caused by this water, picking up contaminants as they diffuse through the water-filled pores of the cement from the interior to the wasteform surface. The mass-flux equation for contaminant release from the source zone by leaching (if diffusion from within the cement limits the release) is given by:

$$
\left[\frac{d M_{i}}{d t}\right]_{\text {leach }}=-M_{i 0^{\prime}} e^{-\lambda_{i} t}\left(\frac{A_{c}}{V_{c}}\right) \sqrt{\frac{D_{c i}}{\pi t}}
$$

where $\mathbf{M}_{\mathrm{io}}$ = initial total mass or activity of contaminant $i$ in the source zone for a cemented waste form ( $\mathrm{g}$ or $\mathrm{Ci}$ )

$A_{c}=$ total external surface area of the cemented waste forms in the contaminant source zone $\left(\mathrm{cm}^{2}\right)$

$\mathrm{V}_{\mathrm{c}}=$ total volume of the cemented waste forms in the contaminant source zone $\left(\mathrm{cm}^{3}\right)$

$D_{\mathrm{ci}}=\cdot$ effective diffusion coefficient of contaminant $\mathrm{i}$ in a cemented waste form $\left(\mathrm{cm}^{2} / \mathrm{yr}\right)$.

The phase distribution of the contaminant within the cement is implicitly expressed in the contaminant's effective diffusion coefficient in the cement. The contaminant-specific diffusion coefficients used in this analyses are given in Appendix B (Table B.4).

\subsubsection{Geochemical Controls on Waste-Form Leaching}

When the waste is a cemented waste form, leached contaminants do not immediately move out of the bottom of the waste zone. Because we assume that the space between these drum-shaped waste forms is filled with soil, the leached contaminants enter this soil zone before exiting the bottom of the waste zone with the percolating water. If the physical and chemical processes in this soil zone are such that contaminant leaching from the soil is slower than the leaching from the waste form itself, then this step of the release process is the limiting step. Therefore, the source-term-release module compares the leaching mass flux calculated by Equation (6.9) with the leaching mass flux calculated by Equations (6.3) through (6.6), where it is assumed that the waste zone was composed of soil. If the release predicted by soil-desorption control or by solubility control is lower, this value is used for the leaching mass flux. 


\subsection{Contaminants of Concern}

Initially, there were 141 radioactive, 47 organic, and 13 inorganic contaminants possible at the various generator/storage sites. To concentrate data-collection efforts and analysis time on those contaminants that would contribute most to associated site hazards, a screening analysis was conducted. This analysis varied for radioactive, inorganic, and organic contaminants because of differing amounts of data available for each group. The amount of data was greatest for the radioactive contaminants, including site-specific radionuclide inventories. The screening analysis for this group of contaminants was divided into two possible transport pathways of concern, airborne and waterborne. A schematic of the screening process is shown in Figure 6.3.

\subsubsection{Radioactive Contaminant-Screening Analysis}

For this analysis, it was assumed that unit amounts of contaminated waste, soil, or debris, with radioactive contaminant concentrations proportional to their inventories, were suspended by wind and transported through the air to a receptor. The human-health risk resulting from this transport is, therefore, a function of the contaminant's inventory and inhalation dose factor. The relative risks for each contaminant were compared and ranked according to their contribution to human-health risk. Those radionuclides whose combined risk contributed $90 \%$ of the total relative risk were designated as the airborne radioactive COCs (Table 6.2).

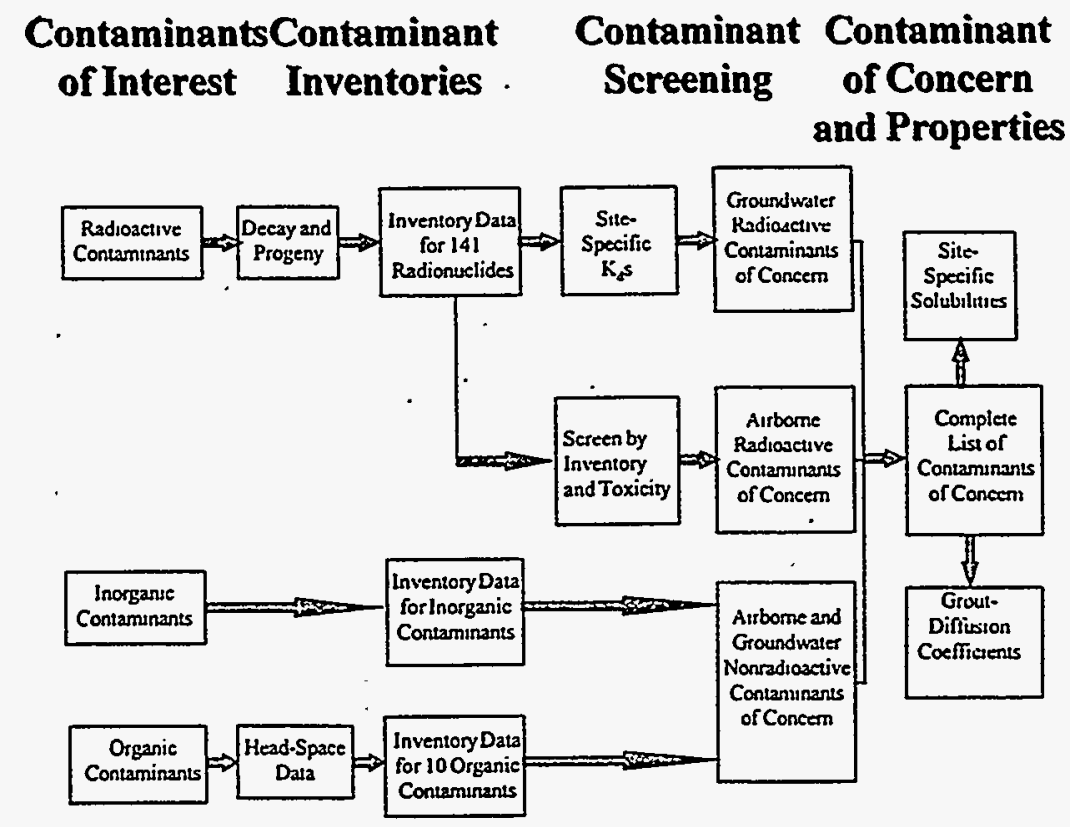

Figure 6.3. Schematic of the Screening Process for Contaminants of Concern 
Table 6.2. Contaminants of Concern for No Action Alternative 2 Analyses

\begin{tabular}{|c|c|c|c|c|}
\hline \multirow[b]{2}{*}{ Contaminant of Concern } & \multicolumn{4}{|c|}{ Type } \\
\hline & $\begin{array}{c}\text { Airborne } \\
\text { Radionuclide }\end{array}$ & $\begin{array}{c}\text { Waterborne } \\
\text { Radionuclide }\end{array}$ & Inorganic & Organic \\
\hline Americium-241 & $x$ & & & \\
\hline Americium-243 & $x$ & & & \\
\hline Carbon-14 & & $x$ & & \\
\hline Curium-243 & & $x$ & & \\
\hline Curium-244 & $\mathrm{x}$ & $\mathbf{x}$ & & \\
\hline Cesium-137 & $x$ & & - & \\
\hline Europium-i52 & $x$ & & & \\
\hline Neptunium-237 & & $x$ & & \\
\hline Protactinium-233 & $x$ & & & \\
\hline Plutonium-238 & $\mathrm{x}$ & $x$ & & \\
\hline Plutonium-239 & $x$ & $x$ & & \\
\hline Plutonium-240 & $x$ & $\mathbf{x}$ & & \\
\hline Plutonium-241 & $x$ & & & \\
\hline Radium-226 & $x$ & & & \\
\hline Strontium-90 & $x$ & & & \\
\hline Uranium-233 & & $x$ & & \\
\hline Uranium-234 & & $x$ & & \\
\hline Uranium-235 & & $x$ & & \\
\hline Lead & & & $x$ & \\
\hline Beryllium & & & $x$ & \\
\hline Cadmium & & & $x$ & \\
\hline Mercury & . & & $x$ & \\
\hline Carbon tetrachloride & & & & $\bar{x}$ \\
\hline Chloroform & & . & & $x$ \\
\hline Methylene chloride & & & & $\bar{x}$ \\
\hline 1,1 Dichloroethylene & & & $\cdot$ & $x$ \\
\hline Methyl ethyl ketone & & & & $x$ \\
\hline 1,1,2,2-Tetrachloroethane & & & & $x$ \\
\hline Toluene & & & & $x$ \\
\hline Chlorobenzene & & & & $x$ \\
\hline 1,2 Dichloroethane & & . & & $x$ \\
\hline 1,1,1-Trichloroethane & & & & $\dot{x}$ \\
\hline
\end{tabular}


Leaching through the vadose zone to the groundwater is the second transport pathway to be considered. Contaminants must be present in significant quantities to result in human-health risk through this pathway. Also, the site must have the necessary climatology and surface-soil characteristics to per- · colate enough water to leach the contaminant from the waste zone and transport it through the vadose zone. The contaminant must then be transported through the aquifer to a groundwater well. There, it must be present in high enough concentrations, with sufficient toxicity, to present significant humanhealth risk. Finally, radioactive contaminants must have long enough half-lives to sustain significant quantities of the contaminant during the time required for transport.

To conduct this screening, slightly simplified MEPAS runs were made. These runs utilized all the release-site data and assumed unit inventories for each contaminant. The release from the waste zone was assumed to be controlled by contaminant $K_{d}$ values (i.e., the release was from a soil/debris TRU waste form and was not solubility limited). Transport through the environment was also controlled by the contaminant $K_{d}$ values. Because of the importance of the assumed $K_{d}$ values, all MEPAS-generated radioactive contaminant $K_{d}$ values were reviewed and improved with site-specific data, where available (see Appendix B, Table B.3). These MEPAS runs produced unit risk factors for each contaminant/site pair that was multiplied by the site-specific inventory to establish the estimated risk for each contaminant at each site. Relative risks for each contaminant were again compared and ranked. The list of radioactive contaminants whose combined risk contributed $99 \%$ of the total relative risk were designated as waterborne COCs (see Table 6.2).

\subsubsection{Inorganic Contaminant-Screening Analyșis}

Reliable inventory data were generally not available for the inorganic contaminants. As a result, a qualitative screening method was employed.

Lead shielding is used to reduce surface-dose rates to acceptable levels for RH TRU waste containers. Lead, therefore, becomes a major part of the total waste mass and is included on the list of COCs. Lead from personal protective equipment is also a major contaminant in CH TRU waste. Inventory estimates for beryllium, cadmium, and mercury were available from DOE (1995c). These contaminants were added to the list of COCs as well. Other inorganic contaminants, such as chromium, were not included on the list of COCs because of the lack of available inventory data.

\subsubsection{Organic Contaminant-Screening Analysis}

As with inorganic contaminants, little reliable inventory data were available for the organic contaminants. Some data reported in DOE (1996a), however, could be used as an indirect indication of the volatile organic concentrations. DOE (1996a) summarizes the results of a head-space-sampling and -analysis study conducted on TRU waste from the INEL and RFETS. That study sampled approximately 930 drums of varying waste types to determine a weighted-average head-space/gas 
composition that could be used for all TRU waste. The weighted values were screened using the concentration toxicity-screening technique presented by the U.S. Environmental Protection Agency (EPA) (1989). This screening provided a list of carcinogenic and noncarcinogenic contaminants that accounts for over $99 \%$ of the human-health risk resulting from migration in air.

This list of COCs was adopted as the organic COCs, with one exception; carbon disulfide was not actually detected in any of the head-space analyses. Carbon disulfide is presented in this analysis in cases where no data were available because one-half of the calculated sample quantitation limit was used as the assumed head-space concentration. Even so, carbon disulfide accounted for $<2 \%$ of the noncarcinogen human-health risk. As a result, carbon disulfide was not included as an organic COC. Data were available for two other contaminants: 1,2-dichloroethane and 1,1,1-trichloroethane. These were added to the 8 screened contaminants to give a total of 10 organic COCs. The ten organic COCs are also listed in Table 6.2 .

\subsubsection{Key Contaminants Evaluated in No Action Alternative 2}

The complete list of COCs for No-Action Alternative 2 is the combination of the waterborne radioactive, airborne radioactive, inorganic, and organic contaminants shown in Table 6.2. The screening analyses resulted in a combined total of 32 COCs. Once this list of COCs was developed, an effort was made to obtain improved values for certain contaminant properties at specific sites. The contaminantdiffusion coefficient in porous cement, required to model contaminant release from cemented TRU waste forms, and contaminant solubility, required to model the solubility bounding case, were evaluated (see Tables A.3 and A.4). Once the updated set of contaminant parameters was developed, actual waste-zone contaminant-release calculations were performed, and fiux factors were generated.

Source-term contaminant-release calculations were run for all 32 COCs for each site and for each waste-form category. If a contaminant on the COCs list was not present at a particular site, an inventory of zero was used for that calculation. Furthermore, if a particular TRU waste-form category was not present at a site, the relative fraction factor used for that TRU waste-form category was zero. Table 6.3 shows the number of non zero flux factors produced for each site and each TRU waste-form category.

\subsection{Example Contaminant-Release Calculations}

This section presents example contaminant-leaching flux versus time curves, illustrating the types of outputs from source-term-release calculations, differences in leaching-release behavior among the two TRU waste-form categories, and differences between soil-desorption and solubility controls. Actual analysis outputs were used as starting points for the example curves presented in Figures 6.4 and 6.5. Important features of the curves, however, were accentuated to better illustrate the general leaching behavior. Run parameters, such as contaminant inventory, half-life, solubility, and $\mathrm{K}_{\mathrm{d}}$, were 
Table 6.3. Nonzero Contaminant-Flux Factors Produced by Site and Waste-Form Category

\begin{tabular}{|l|c|c|}
\hline \multirow{2}{*}{ Release Site } & \multicolumn{2}{|c|}{ Number of Nonzero Flux Factors } \\
\cline { 2 - 3 } & Soil/Debris & Cement \\
\hline Hanford 200E & 30 & - \\
\hline Hanford 200W & 30 & - \\
\hline INEL & 32 & 32 \\
\hline LLNL & 28 & 28 \\
\hline LANL & 31 & 31 \\
\hline ORNL & 32 & 32 \\
\hline RFETS & 25 & 5 \\
\hline SRS & 29 & 29 \\
\hline
\end{tabular}

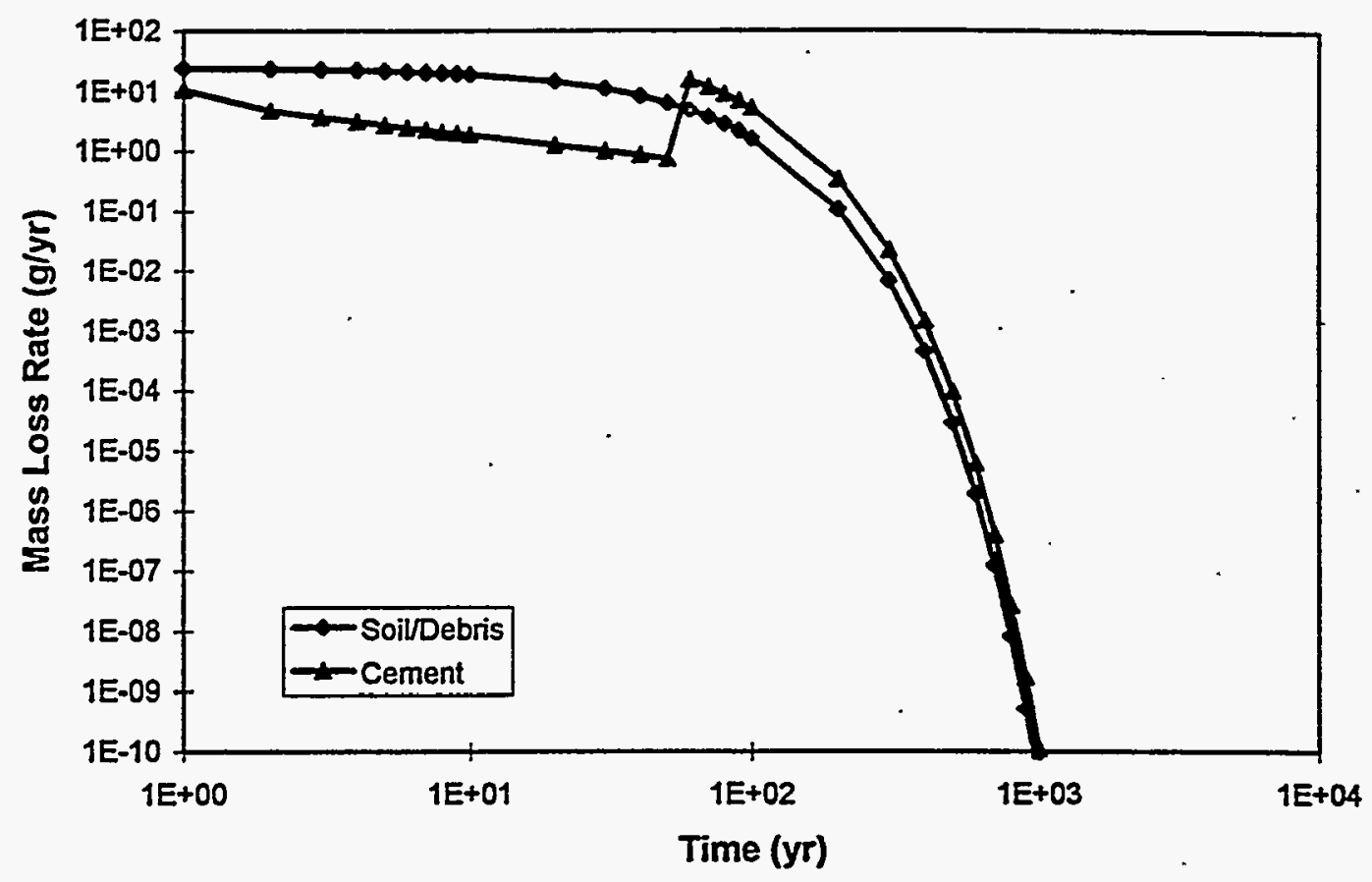

Figure 6.4. Comparison of Contaminant-Leaching-Flux Curves from Different Waste Forms 


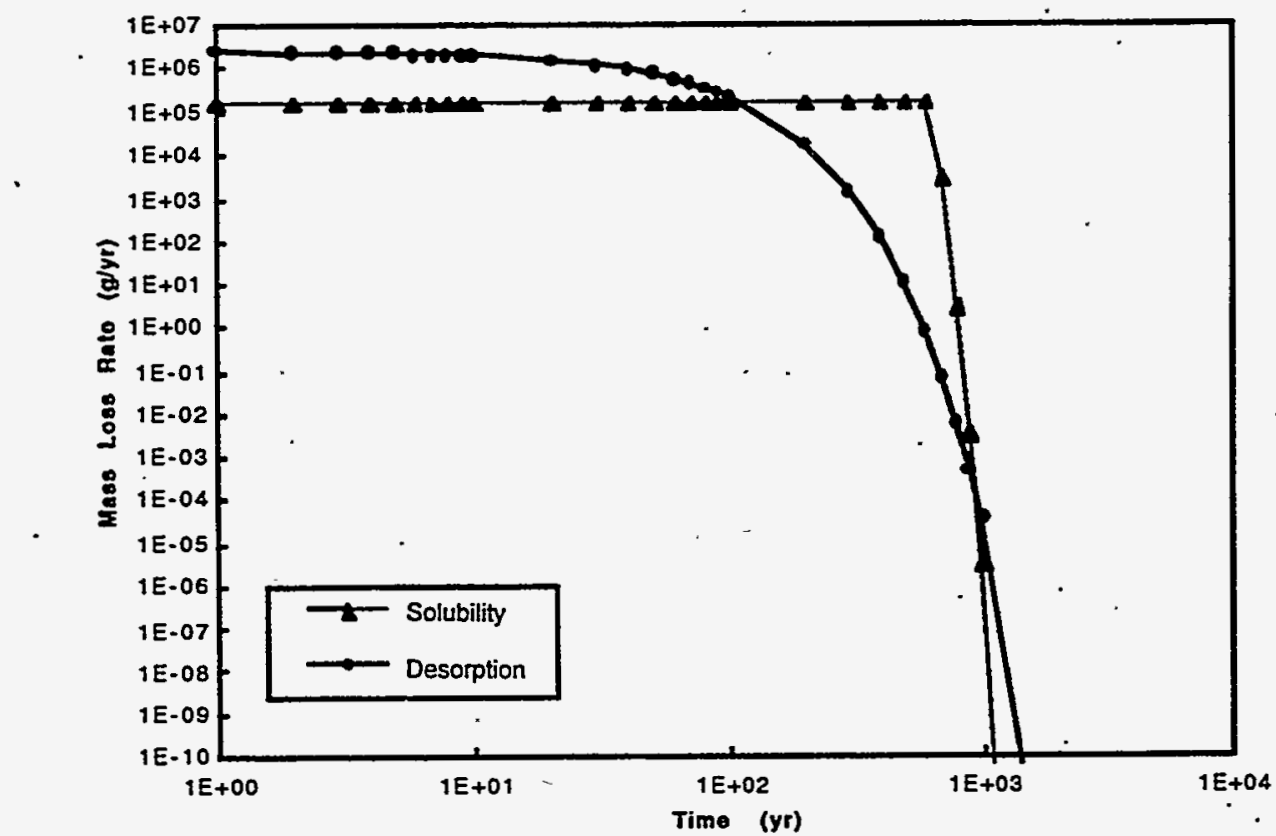

Figure 6.5. Comparison of Contaminant-Leaching-Flux Curves for Desorption and Solubility Controlled Cores

adjusted. In addition, to enhance the effect of failure of the cemented TRU waste form, 50 rather than 500 yrs was assumed as the point at which the TRU waste-form failure occurs. Note also that the initial contaminant inventory and waste-zone size and shape are the same for all cases shown within a figure.

Figure 6.4 is a logarithmic plot of contaminant-leaching flux versus time for the two TRU wasteform types. Initially, contaminants are lost more rapidly from the soil/debris TRU waste form and the release curve for cement falls off more quickly. This is due to the diffusion-release mechanisms within the cement waste form that set up contaminant concentration spatial gradients that inhibit the rate of release over time. Eventually, however, the contaminant release from the soil/debris TRU waste form also falls because the contaminant inventory in the soil/debris TRU waste form becomes exhausted.

As time goes on, release from the soil/debris TRU waste form continues to fall off monotonically, whereas release from the cemented TRU waste form increases at the point when the waste form fails. Because the initial contaminant release from cement is slower than that from soil/debris, more of the contaminant remains in the cemented TRU waste form at the time of failure than remains in the soil/debris TRU waste form at a corresponding time. The cemented TRU waste form is assumed to degrade quickly into a porous material similar to the soil/debris waste form. At this time, the cemented TRU waste form releases contaminants according to the same mechanisms as the soil/debris TRU waste form. The higher contaminant inventory at the time of failure subsequently results in higher release 
from the cement. Therefore, in the conceptual model adopted for this analysis, the cementing process only delays contaminant release unless significant loss via radioactive decay occurs while the contaminant is held in the waste form.

Figure 6.5 compares contaminant-leaching flux curves for soil-desorption and solubility controls. Although the contaminant inventory used was different, the soil-desorption-control curve has the same features as the leaching curve for the soil/debris TRU waste form in Figure 6.4. For the desorption case, the solubility was set high enough, relative to the contaminant inventory, so that all of the contaminant could reside in the aqueous and sorbed phases of the porous medium in the source zone.

The solubility value in the solubility-control curve was reduced such that excess contaminant would partition into a solid precipitate or organic liquid phase. In this case, the aqueous concentration of the contaminant will always equal its solubility as long as the contaminant excess continues. The solubilityleaching flux, therefore, is initially lower than that for the soil-desorption-controlled case; and the curve is flat as long as the concentration in the leaching solution is solubility controlled. Initially, more contaminant remains in the source zone for the solubility-controlled case than for the soil-desorptioncontrolled case. The leaching release from the solubility-controlled case, therefore, eventually . becomes greater than that from the soil-desorption-controlled case. 


\subsection{Airborne and Waterborne Transport}

To calculate the population impacts at air-, groundwater-, and surfacewater-receptor locations, model parameters were identified in the analysis of airborne and waterborne contaminant transport.

\subsection{Airborne-Transport Parameters}

Parameters related to atmospheric release, transport, and deposition analyses require surface-soil characteristics and regional climatological information. The surface-soil and local climatological. information required to estimate soil-suspension rates were obtained from Holdren et al. (1995). The regional meteorological data and atmospheric dispersion data, in the form of a joint-frequency distribution of wind direction, wind speed, and atmospheric stability, were obtained from DOE (1995a).

\subsection{Waterborne-Transport Parameters}

Parameters related to the hydrologic and geologic characteristics of each site analyzed were selected from site-specific environmental settings developed for the WM PEIS and baseline environmental management report projects (Holdren et al. 1995). The assumed environmental settings for each of major generator/storage site analyzed were summarized in Chapter 4.0. An environmental settings database was used to obtain the number of vadose zone layers at each site, the thicknesses and hydraulic conductivity properties of the vadose zone and aquifer layers, and a suite of physicochemical properties for all layers.

MEPAS source-term calculations involve using site-specific parameters from the environmental setting to calculate secondary parameters that are important to contaminant-release calculations. Table 7.1 shows MEPAS-calculated water-infiltration- and soil-erosion-rate values for each site. The calculated water-infiltration rate is based on local climatology, such as precipitation, cloudiness, wind speed, and humidity; surface-soil properties; and vegetation cover. A water-balance analysis was conducted to estimate the runoff, evapotranspiration, and infiltration rates specific to the site.

\subsection{Calculated Soil-Erosion Rates for Each Site}

As stated earlier, MEPAS source-term calculations involve using site-specific parameters from the environmental setting to calculate secondary parameters that are important to the contaminant-release calculations. Table 7.1 showed MEPAS-calculated water-infiltration and soil-erosion rates for each site. Wind-suspension and overland-water-flow soil-erosion rates were computed using site-specific surface soil and local climatological information. Table 7.1 also provided an estimate of the amount of surface soil removed over the 10,000 -yr modeling period to determine whether the $1.2-\mathrm{m}$ overburden could be removed to expose waste to the surface. 
Table 7.1. MEPAS-Calculated Water-Infiltration and Soil-Removal Rates for Each Site

\begin{tabular}{|l|l|l|l|l|l|l|l|l|}
\hline & $\begin{array}{c}\text { Hanford } \\
200 \mathrm{E}\end{array}$ & $\begin{array}{c}\text { Hanford } \\
\mathbf{2 0 0 W}\end{array}$ & NEL & LLNL & LANL & ORNL & RFETS & SRS \\
\hline Infiltration (cm/yr) & 1.49 & 1.49 & 1.43 & 9.28 & 0.633 & 42.2 & 0.156 & 24 \\
\hline Annual precipitation (cm) & 16 & 16 & 22 & 37 & 45 & 139 & 39 & 110 \\
\hline $\begin{array}{l}\text { \% of precipitation to infiltration } \\
\text { (\%) }\end{array}$ & 9 & 9 & 6 & 25 & 1.4 & 32 & 0.4 & 22 \\
\hline $\begin{array}{l}\text { Wind-suspension-erosion rate } \\
(\mathrm{cm} / \mathrm{yr})\end{array}$ & $5.8 \mathrm{E}-04$ & $5.8 \mathrm{E}-04$ & $4.5 \mathrm{E}-02$ & $6.1 \mathrm{E}-03$ & $1.3 \mathrm{E}-03$ & $3.5 \mathrm{E}-05$ & $7.7 \mathrm{E}-03$ & $2.0 \mathrm{E}-03$ \\
\hline $\begin{array}{l}\text { Soil eroded by wind in } 10,000 \mathrm{yr} \\
\text { (ft) }\end{array}$ & 0.19 & 0.19 & 1.48 & 2.00 & 0.44 & 0.01 & 2.53 & 6.59 \\
\hline $\begin{array}{l}\text { Overland-flow-erosion rate } \\
\text { (cm/yr) }\end{array}$ & $1.9 \mathrm{E}-04$ & $1.9 \mathrm{E}-04$ & $3.4 \mathrm{E}-03$ & $1.4 \mathrm{E}-02$ & $5.2 \mathrm{E}-03$ & $1.2 \mathrm{E}-02$ & $6.5 \mathrm{E}-04$ & $1.1 \mathrm{E}-02$ \\
\hline $\begin{array}{l}\text { Soil eroded by water in } 10,000 \mathrm{yr} \\
\text { (fi) }\end{array}$ & 0.06 & 0.06 & 1.11 & 4.06 & 1.70 & 3.79 & 0.21 & 3.45 \\
\hline $\begin{array}{l}\text { Total soil erosion in } 10,000 \mathrm{yr} \\
\text { (ft) }\end{array}$ & 0.25 & 0.25 & 1.59 & 6.06 & 2.14 & 3.81 & 2.74 & 4.10 \\
\hline
\end{tabular}

\subsection{Air- and Water-Receptor Locations}

Population impacts from atmospheric releases were calculated for all sites using site-specific jointfrequency and population data. Population impacts from domestic and agricultural water uses could be calculated for only some of the sites. The atmospheric population distributions were obtained from DOE (1995a). Further, a review was made of the annual site reports (e.g., Arnett et al. 1995; Dirkes and Hanf 1995; Martin Marietta Energy Systems, Inc. 1994) from which specific recommendations regarding population exposure for each site were made.

\subsection{Unit-Transport Factors}

The site-specific UTFs provide an estimate of environmental concentrations for each COC for each receptor related to each exposure medium (groundwater, surfacewater, or atmosphere). These UTFs are convoluted with the TRU waste-form-specific contaminant-UFFs, as discussed in Chapter 2.2. 


\subsection{Calculation of Unit Exposure and Unit Impact Factors}

The human-health-impact analyses require definition of the UDF and the UIF. Parameter arrays can be calculated from information in the MEPAS and GENII output files. The definition of UDFs involves average daily intake (milligrams per kilogram per day) for chemicais and lifetime radiation dose (rem) for radionuclides. The UIF relates intake or dose to risk or hazard index for each contaminant, as appropriate. The UIF and UDF are defined for contaminant inhalation and ingestion and for external radiation exposure routes. The following sections describe the calculation of UDF and UIF from the health-impact endpoint values provided in the MEPAS and GENII output files for both individual and population exposures. Background information and scope of the analyses are summarized first.

\subsection{Background Information and Scope of Analyses}

These analyses require calculation of population health impacts as well as the MEI health impacts. The UIF values for individual and population exposures are the same and provide conversion from intake or dose to risk. These values are based on slope factors, reference doses, and radiation doseconversion factors. The UDF values differ from UIF values, in that the population UDF is evaluated using average parameter values instead of 90 th percentile values used for MEI impacts. The number of people exposed is not included in UDF or UIF values; however, the population exposed must be included in the final analysis of risk because populations are defined for each release site and receptor location. The UDF and UIF values are independent of release site and receptor location.

Many combinations of variables must be included to generate the UDF and UIF. These variables are described below.

- Exposure Scenario - Analyses are performed for an MEI and for local populations; both scenarios involve the potential exposure to airborne, waterborne, and soil contamination.

- Receptor Type - As with the exposure scenario, MEI and local population receptor types are evaluated; each receptor type requires the generation of specific UIF/UDF files; they cannot be combined into one calculation.

- Exposure Media - Each analysis is performed with the appropriate exposure media for the MEI and local population scenarios; types of exposure media include soil per unit mass, soil per unit area, air, and groundwater.

- Contaminant Type - Specific output files are generated for each type of contaminant (noncarcinogenic chemicals, carcinogenic chemicals, and radionuclides); as with previous analyses, 
the list of chemicals in the two chemical file types is identical. All chemicals are analyzed for carcinogenic risk and noncarcinogenic hazard index. Chemical types that are not appropriate for a specific chemical will result in a zero health-impact result.

\subsection{Individual UDF and UIF Calculations}

The output file provides the cancer incidence risk and hazard index values for each exposure pathway, for each contaminant, for one scenario, for one contaminant type, and for one set of up to 20 contaminants. The file also contains the slope factors and reference doses used for the analysis. The postprocessor program extracts the UDF and UIF from each output file, as necessary, for subsequent calculations. For each set of results, the UDF values are summed over the specific values for each exposure pathway within an exposure route. The calculation output is a set of UDF values for each contaminant, calculated from the risk/hazard index values.

Because all radiation risk-conversion calculations use the same conversion factor, the UIF for all radionuclides and exposure routes is one value. For calculation of total cancer incidence, the UIF is set

to $7.3 \mathrm{E}-04 \mathrm{risk} / \mathrm{rem}$. For total cancer fatalities, the UIF is set to $6.3 \mathrm{E}-04 \mathrm{risk} / \mathrm{rem}$, a possible exception in the use of one value for each endpoint is for the industrial scenario and specific health-effect-conversion factors may be used to represent exposure of workers of occupational age.

\subsection{Population UDF and UIF Calculations}

Population UDF and UIF values are calculated according to Equations (2.5) and (2.6) in Chapter 2.0 for individual UDF and UIF values. The difference being that the population UEF risk values in the output files must be taken from files generated specifically for population exposures. The specific population data used for this analysis is derived from site-specific information. Table 8.1 shows the different population data for atmospheric and surfacewater population receptors for the 7 sites analyzed. There are no population UDF and UIF for noncarcinogenic chemicals. 
Table 8.1. Site-Specific Population Data used for No Action Alternative 2 Analysis

\begin{tabular}{|c|c|c|}
\hline Major Generator/Storage Sites & $\begin{array}{l}\text { Atmospheric } \\
\text { Population }^{(2)}\end{array}$ & Surfacewater Population \\
\hline Hanford Site & 377645 & $33000^{(6)}$ \\
\hline Idaho National Engineering Laboratory & 153061 & NA \\
\hline Lawrence Livermore National Laboratory & 6324234 & NA \\
\hline Los Alamos National Laboratory & 296546 & NA \\
\hline Oak Ridge National Laboratory & 881652 & $6841^{(c)}$ \\
\hline $\begin{array}{l}\text { Rocky Flats Environmental Technology } \\
\text { Site }\end{array}$ & 2171877 & NA \\
\hline Savannah River Site & 620618 & $50000^{(d)}$ \\
\hline Total Sum Over All Sites & 10825633 & 89841 \\
\hline \multicolumn{3}{|c|}{$\begin{array}{l}\text { (a) All atmospheric population data was obtained WM-PEIS report (DOE 1995a). } \\
\text { (b) Hanford Site surfacewater population data was obtained from Hanford Site Environmental } \\
\text { Report for Calendar Year } 1994 \text { (Dirkes and Hanf 1995). } \\
\text { (c) Oak Ridge National Laboratory surfacewater population data was obtained from Oak Ridge } \\
\text { Reservation Annual Site Environmental Report for } 1993 \text { (Martin Marietta Energy Systems, Inc. } \\
\text { 1994). } \\
\text { (d) Savannah River Site surfacewater population data was obtained from Savannah River Site } \\
\text { Environmental Report for } 1992 \text { (Arnett et al. 1995). }\end{array}$} \\
\hline
\end{tabular}




\subsection{Summary of Long-Term Impacts of No Action Alternative 2}

The No Action Alternative was included among those alternatives considered in the FEIS (DOE 1980) and SEIS-I (DOE 1990). The FEIS and SEIS-I analyzed the environmental consequences of this alternative under several different assumptions and conditions. In general, it is estimated that if the DOE would provide effective monitoring and maintenance of storage facilities, adverse health effects for the general public would be quite small, and the principal adverse effects, also small, would be related to occupational activity at the facility. Health effects would continue at such levels for the indefinite future under the hypothesis of DOE control.

However, if the DOE were to lose institutional control of storage facilities, it is estimated that intruders could receive substantial radiation doses, a situation that could persist for the indefinite future. In addition, contaminants in TRU wastes stored in shallow burial trenches and surface-storage facilities will eventually be released and would persist in the surrounding environments at the generator/storage sites exposing onsite and offsite populations to chronic health risks.

The Record of Decision on the FEIS, which was published on January 28, 1981, determined, as part of the basis for decision, that the No Action Alternative was unacceptable. This determination was made at the time because of the potential impacts of natural, low-probability events and human intrusion at storage facilities after governmental control of the site is lost. In SEIS-I, a summary of the FEIS analysis was provided and the same conclusion was reached in the Record of Decision, which was published on June 21, 1990, that the No Action Alternative was unacceptable.

The long-term impacts of the No Action Alternative following loss of institutional control were reexamined for this analysis of No Action Alternative 2. The effect of human intrusion was reexamined because of the changed estimated volumes and inventories of future-generated TRU wastes. .This analysis also examined the long-term impacts of environmental releases of contaminants from stored TRU wastes at the 10 major generator/storage sites.

This chapter provides a summary of long-term impacts from stored TRU wastes at the 7 major generator/storage sites for 10,000 years following loss of institutional control. This analysis estimates - the impacts of TRU wastes as a source of direct exposure and as a long-term contaminant source for release to surface and subsurface exposure and points in the environment. Scenarios analyzed include direct exposure to wastes and airborne and waterborne release of contaminants from wastes stored in shallow earth-covered trenches or earthen berms and wastes stored on exposed surface pads or in surface enclosures and buildings.

The impacts to human health from waste intrusion and long-term environmental release were focused on the impacts of wastes at 7 of the 10 major generator/storage sites because the majority . . (99\%) of the wastes generated are stored there. Estimates for RH TRU waste impacts were only made 
at sites storing RH TRU wastes, which are Hanford, INEL, LANL, and ORNL. For buried wastes, no estimates of impacts were made for either $\mathrm{CH}$ or RH TRU wastes at LLNL and RFETS because neither of these sites store wastes in buried configurations.

\subsection{Impacts from Intrusion into Wastes}

Following are radiological and hazardous chemical impacts to postulated intruders for buried and surface-stored wastes.

\subsubsection{Buried Waste Storage}

With loss of institutional control, an inadvertent intruder could come into contact or become directly exposed to wastes stored in shallow burial storage facilities by drilling into the wastes. A drilling intruder scenario postulates an individual who would drill into the wastes and become exposed to waste material brought to the land surface by the drilling process. Another indirect exposure from this scenario would be an intruder gardener scenario, which assumes that an individual would be directly exposed to waste material brought to the land surface by the drilling scenario. The individual would farm in soil contaminated by the waste materials and would ingest contaminated materials and eat produce generated from the garden. To bound the impact, calculations assumed the intrusions occurred at loss of institutional control. The analyses performed for both $\mathrm{CH}$ and RH TRU wastes are summarized below.

The estimated annual maximum MEI LCF to a hypothetical driller from CH TRU waste, summarized in Table 9.1, ranges from 1.5E-05 to 9.0E-05 for the 7 sites with buried waste. The estimated annual maximum MEI LCF from RH TRU waste ranges from 6.6E-06 to 3.8E-04 over the 4 sites that store RH TRU waste (Table 9.1). The highest estimated annual MEI LCFs for CH TRU waste calculated for the driller scenario was at the SRS. The highest estimated annual MEI LCFs for RH TRU waste was calculated for Hanford for the driller scenario.

The estimated annual maximum MEI LCF for the gardener exposed to CH TRU waste, summarized in Table 9.1, ranges from 1.8E-04 to 4.4E-03, whereas the 30-yr cumulative MEI LCF ranges from 9.7E-03 to 6.3E-02. The estimated maximum MEI LCF to the gardener from RH TRU waste ranges from 1.8E-04 to 3.2E-03, whereas the 30-yr cumulative MEI LCF ranges from 4.0E-03 to 6.7E-02 (see Table 9.1). The highest estimated annual MEI LCF for CH TRU waste calculated for the gardener scenario was at the SRS. The highest estimated annual MEI LCFs for RH TRU waste was calculated for Hanford for the gardener scenario. Summary tables of risk results for driller and gardener intruder scenarios are provided in Appendix D.

Only the atmospheric inhalation pathway was evaluated for the hazardous chemical impacts for the intruder scenarios and these results are only dependent on the air concentration and driller's inhalation

rate. Therefore, all the results for the hazardous contaminants are site-independent. For the short-term exposure of the driller, the resulting values are compared to the permissible exposure limits. Table 9.2 shows the site-independent results for the hazardous contaminants. All driller intruder scenario 
Table 9.1. Summary of Radiological Impacts for Intruder Scenarios by Site

\begin{tabular}{|c|c|c|c|c|c|c|c|}
\hline Intruder Scenario & Hanford & INEL & LLNL & LANL & ORNL & RFETS & SRS \\
\hline \multicolumn{8}{|c|}{$\begin{array}{c}\text { Contact-Handled Waste Radiological Impacts } \\
\text { (Latent Cancer Fatalities) }\end{array}$} \\
\hline Driller & $1.5 \mathrm{E}-05$ & $7.1 \mathrm{E}-05$ & $0.0 E+00^{(a)}$ & $3.0 \mathrm{E}-05$ & $7.0 \mathrm{E}-05$ & $0.0 \mathrm{E}+00^{(\mathrm{a})}$ & $9.0 \mathrm{E}-05$ \\
\hline $\begin{array}{c}\text { Gardener/ } \\
\text { Maximum Annual }\end{array}$ & 4.1E-04 & $5.8 E-04$ & $0.0 E+00^{(a)}$ & $1.8 \mathrm{E}-04$ & $6.8 \mathrm{E}-04$ & $0.0 \mathrm{E}+00^{(a)}$ & $4.4 \mathrm{E}-03$ \\
\hline $\begin{array}{l}\text { Gardener/ } 30 \text { Year } \\
\text { Cumulative }\end{array}$ & $9.7 \mathrm{E}-03$ & $1.4 \mathrm{E}-02$ & $0.0 \mathrm{E}+00^{(a)}$ & 2.1E-02 & $1.6 \mathrm{E}-02$ & $0.0 E+00^{(a)}$ & $6.3 \mathrm{E}-02$ \\
\hline Scavenger & $1.6 \mathrm{E}-03$ & $2.1 E-03$ & $6.4 \mathrm{E}-04$ & $3.3 E-03$ & $2.6 \mathrm{E}-03$ & $1.9 \mathrm{E}-02$ & $1.0 \mathrm{E}-02$ \\
\hline $\begin{array}{c}\text { Farm Family } \\
\text { Maximum Annual }\end{array}$ & $5.7 \mathrm{E}-01$ & $8.2 \mathrm{E}-01$ & $2.4 \mathrm{E}-01$ & $1.2 \mathrm{E}+00$ & $1.2 E+00$ & $4.0 \mathrm{E}+00^{(b)}$ & $3.8 \mathrm{E}+00$ \\
\hline $\begin{array}{c}\text { Farm Family } \\
30 \text { Year Cumulative }\end{array}$ & $4.0 E+00^{(b)}$ & $4.0 E+00^{(b)}$ & $4.0 \mathrm{E}+00$ (b) & $4.0 \mathrm{E}+00$ (b) & $4.0 E+00^{(b)}$ & $4.0 \mathrm{E}+00^{(\mathrm{b})}$ & $4.0 \mathrm{E}+00^{(\mathrm{b})}$ \\
\hline \multicolumn{8}{|c|}{$\begin{array}{c}\text { Remote-Handled Waste Radiological Impacts } \\
\text { (Latent Cancer Fatalities) }\end{array}$} \\
\hline Driller & $3.8 \mathrm{E}-04$ & $6.5 \mathrm{E}-05$ & $0.0 \mathrm{E}+00^{(c)}$ & $.6 .6 \mathrm{E}-06$ & $4.6 \mathrm{E}-05$ & $0.0 \mathrm{E}+00^{(c)}$ & $0.0 E+00(c)$ \\
\hline $\begin{array}{c}\text { Gardener/ } \\
\text { Maximum Annual }\end{array}$ & $3.2 \mathrm{E}-03$ & $8.4 \mathrm{E}-04$ & $0.0 \mathrm{E}+00(\mathrm{c})$ & $1.8 \mathrm{E}-04$ & $8.2 E-04$ & $0.0 \mathrm{E}+00(\mathrm{c})$ & $0.0 E+00(c)$ \\
\hline $\begin{array}{l}\text { Gardener/ } 30 \text { Year } \\
\text { Cumulative }\end{array}$ & $6.7 \mathrm{E}-02$ & $1.7 \mathrm{E}-02$ & $0.0 \mathrm{E}+00(\mathrm{c})$ & $4.0 \mathrm{E}-03$ & $1.6 \mathrm{E}-02$ & $0.0 E+00(c)$ & $0.0 E+00^{(c)}$ \\
\hline Scavenger & $1.2 \mathrm{E}-02$ & 2.1E-03 & $0.0 E+00(c)$ & $6.9 \mathrm{E}-04$ & $1.4 \mathrm{E}-03$ & $0.0 E+00(c)$ & $0.0 E+00^{(c)}$ \\
\hline $\begin{array}{c}\text { Farm Family } \\
\text { Maximum Annual }\end{array}$ & $4.0 \mathrm{E}+00$ (b) & $1.8 E+00$ & $0.0 E+00(c)$ & $3.3 \mathrm{E}-01$ & $1.8 E+00$ & $0.0 \mathrm{E}+00(\mathrm{c})$ & $0.0 \mathrm{E}+00(\mathrm{c})$ \\
\hline \begin{tabular}{|c|} 
Farm Family \\
30 Year Cumulative
\end{tabular} & $4.0 E+00(b)$ & $4.0 E+00(b)$ & $0.0 E+00(c)$ & $4.0 \mathrm{E}+00^{(b)}$ & $4.0 E+00^{(b)}$ & $0.0 \mathrm{E}+00(\mathrm{c})$ & $0.0 E+00(c)$ \\
\hline \multicolumn{8}{|c|}{$\begin{array}{l}\text { (a) Value is zero because site does not have buried TRU waste. } \\
\text { (b) Value is limited to the number of exposed population, calculated value is higher. } \\
\text { (c) Value is zero because site does not have remote-handled TRU waste. }\end{array}$} \\
\hline
\end{tabular}

estimated impacts are much less than the permissible exposure limits, with the exception of RH lead which is three times the limit. The gardener intruder scenario estimated impacts above the 1.0E-06 reference level for chemical carcinogens but below. the 1.0 level for noncarcinogens.

\subsubsection{Surface-Stored Wastes}

With loss of institutional control, inadvertent intruders may come into more direct contact and be directly exposed to waste in surface storage facilities. To estimate this impact, exposure calculations 
Table 9.2. Summary of Hazardous Contaminants for the Driller and Gardener Intruder Scenarios ${ }^{(2)}$

\begin{tabular}{|l|c|c|c|c|}
\hline $\begin{array}{c}\text { Hazardous } \\
\text { Contaminant }\end{array}$ & \multicolumn{4}{|c|}{ Contact- or Remote-Handled TRU Waste(b) } \\
\hline & \multicolumn{2}{|c|}{ Driller Intruder Scenario } & \multicolumn{2}{c|}{ Gardener Intruder Scenario } \\
\hline & $\begin{array}{c}\text { Cancer Incidence } \\
\text { for Chemical } \\
\text { Carcinogens }\end{array}$ & $\begin{array}{c}\text { Percent of Permissible } \\
\text { Exposure Limit for } \\
\text { Noncarcinogens }\end{array}$ & $\begin{array}{c}\text { Cancer Incidence } \\
\text { for Chemical } \\
\text { Carcinogens }\end{array}$ & $\begin{array}{c}\text { Hazard Quotient } \\
\text { for Non- } \\
\text { carcinogens }\end{array}$ \\
\hline Beryllium & $1.3 \mathrm{E}-10$ & $1.7 \mathrm{E}-02$ & $5.1 \mathrm{E}-01$ & $3.0 \mathrm{E}-05$ \\
\hline Cadmium & $1.3 \mathrm{E}-12$ & $9.8 \mathrm{E}-05$ & $5.5 \mathrm{E}-03$ & $4.4 \mathrm{E}-07$ \\
\hline Lead & $0.0 \mathrm{E}+00^{(c)}$ & $\begin{array}{c}\text { CH: } 2.7 \mathrm{E}-02 . \\
\text { RH: } 3.0 \mathrm{E}+00 .\end{array}$ & $0.0 \mathrm{E}+00^{(c)}$ & $\begin{array}{c}\text { CH: } 1.0 \mathrm{E}-03 \\
\text { RH: } 1.1 \mathrm{E}-01\end{array}$ \\
\hline Mercury & $0.0 \mathrm{E}+00^{(c)}$ & $1.2 \mathrm{E}-02$ & $0.0 \mathrm{E}+00^{(c)}$ & $8.9 \mathrm{E}-05$ \\
\hline
\end{tabular}

(a) Hazardous impacts are assumed to be the same at all sites.

(b) Results are independent of whether the waste is contact or remote-handled except where noted.

(c) Value zero because contaminant does not produce known carcinogenic effects.

were performed for a hypothetical scavenger intruder assumed to come into direct contact with the surface-stored waste during a $24-\mathrm{h}$ period after loss of institutional control. The scavenger was assumed to be exposed via inhalation of resuspended contamination and external and inadvertent ingestion of contaminated soil while at the site.

The estimated maximum MEI LCF to a hypothetical scavenger (given in Table 9.1) exposed to surface-stored CH TRU waste ranges from 6.4E-04 to 1.9E-02. The highest impacts for CH TRU waste were estimated at RFETS. The estimated LCF to the scavenger from surface-stored RH TRU waste ranges from 6.9E-04 to 1.2E-02. The highest MEI impacts for RH TRU waste were estimated for Hanford. Summary tables of risk results for scavenger intruder analyses are provided in Appendix D.

Another potential intruder scenario for surface-stored waste examined was a hypothetical family that lives and farms on a plot of land immediately over the surface-stored waste once the waste degrades to the point where it becomes indistinguishable from the surrounding land. For these conditions, the maximally exposed intruder in the family could be exposed via ingestion of contaminated food crops grown in the contaminated soil, inhalation of resuspended contamination, external exposure to the soil, and inadvertent ingestion of contaminated soil. If this scenario ever occurred, the farmer and family would likely receive severe and potentially lethal doses over a lengthy period of time. Estimated maximum annual MEI LCFs range from 2.4E-01 to 4.0E +00 for CH TRU waste and 3.3E-01 to $4.0 \mathrm{E}+00$ for RH TRU waste (Table 9.1). For the 30-yr cumulative farm family scenario, maximum LCF health impact for all sites was $4.0 \mathrm{E}+00$. Summary tables of risk results for farm family intruder scenario analyses are provided in Appendix D. 
As.in the case of buried waste, health impacts of hazardous chemicals, including volatile organics contained within TRU waste, were estimated to be below. permissible exposure limits for the driller intruder scenario. Beryllium's and cadmium's cancer incidence impacts are above the 1.0E-06 reference level for the gardener intruder scenario. None of the noncarcinogenic contaminants had a hazard quotient above the reference dose limit of $1.0 \mathrm{E}+00$.

\subsubsection{Summary of Intruder Scenario Results}

Of all the intruder scenarios, the farm family intruder scenario estimated impacts are at least 2 orders-of-magnitude higher than any of the other scenarios. This is because the farm family intruder scenario has the most exposure routes and exposure time of all the scenarios. In fact, for the 30-year exposure duration, the farm family intruder scenario health impacts for all sites are estimated to be highest possible (i.e., risk of 1.0E+00). The health impacts between $\mathrm{CH}$ and $\mathrm{RH}$ TRU waste are generally equivalent, although there are less sites that contain RH TRU waste. The SRS has the highest estimated health impacts for the CH TRU waste for the driller scenario (9.0E-05 LCFs) as well as for the gardener intruder scenarios (6.3E-02 LCFs over 30 years with a maximum annual impact in year 1 of 4.4E-03); the RFETS has the highest estimated health impacts for the CH TRU waste scavenger (1.9E-02 LCFs) and farm family intruder scenarios (4 LCFs in the first year). For the RH TRU waste, the Hanford Site has the highest estimated health impacts for all scenarios.

For the chemical carcinogens in the driller scenario, at all sites, the cancer incidence is at least 4 orders-of-magnitude below the $1.0 \mathrm{E}-06$ limit generally used to indicate a level of concern. Chemical noncarcinogens in the $\mathrm{CH}$ driller scenario are in general 2 orders-of-magnitude below the permissible exposure limits allowed in short-term occupational settings. However, in the RH waste, lead is 3 times the permissible exposure limit at all sites. For the gardener intruder scenario, the cancer incidence values for beryllium and cadmium are estimated (5.1E-01 and 5.5E-03, respectively) to be above the 1.0E-06 limit generally used to indicate a level of concern. For the chemical noncarcinogens, only lead is estimated (1.1E-01) to approach the reference level of $1.0 \mathrm{E}+00$. In general, the hazardous chemical impacts from the intruder scenarios are not estimated to be significant from the TRU waste at the 7 sites evaluated.

\subsection{Long-Term Impacts of Environmental Release}

Contaminants in TRU waste stored in shallow burial trenches and surface-storage facilities within site-specific environmental settings (see Chapter 4.0) would eventually be released to the surrounding environments at the treatment sites. Contaminants within the buried or surface-stored waste would be leached and released to underlying soils and aquifer systems at depth. Eventually, at most sites, contaminants would reach groundwater and migrate laterally to a downgradient receptor location. Contaminants may also eventually be discharged into nearby surfacewater bodies. Once in these surfacewater systems, dilute concentrations of the contaminants would become available to public water intakes for nearby communities. 
Waste stored in surface facilities would also degrade and become available in the environment by the processes of direct air and water erosion, deposition onto soils surrounding the site, and resuspension of contaminated soils in air. The general surrounding onsite and offsite population would be exposed to these contaminants as they are redistributed into the environment by these cyclic and ongoing processes.

For this analysis, the impacts to a hypothetical farm family of two adults and two children that . would live $300 \mathrm{~m}$ downgradient of the waste-storage area were considered. It was assumed that the family would engage in farming activities, such as growing and consuming its own crops and livestock. The family would use contaminated groundwater as a source of drinking water and for watering the crops and animals. The MEI in the family would be exposed via ingestion of contaminated food crops grown in the contaminated soil, inhalation of resuspended contamination, external exposure to the soil, and inadvertent ingestion of contaminated soil. This analysis also considered the offsite population that could potentially be exposed to environmental releases to the air and surfacewater. For analyses of buried-waste releases, all CH and RH TRU wastes were combined into a single waste-disposal unit, and only the groundwater pathway was considered. For analyses of surface-stored waste releases, all CH and RH TRU wastes were combined into a single waste-storage unit and were allowed to be released to all pathways (groundwater, surfacewater, and atmospheric).

\subsubsection{Radiological Impacts}

The estimated lifetime impacts over 10,000 years of environmental release of radioactive contaminants from buried and surface-stored waste at the 7 generator/storage sites are summarized in Table 9.3. The maximum lifetime MEI dose for all sites ranges from $1.5 \mathrm{E}-03$ to $2.7 \mathrm{E}+01$

Table 9.3. Summary of Radioactive Impacts to the Maximally Exposed Individual and Population after Loss of Institutional Control at the Seven Major Generator/Storage Sites

\begin{tabular}{|l|c|c|c|c|l|}
\hline \multicolumn{1}{|c|}{$\begin{array}{c}\text { Major } \\
\text { Generator/ } \\
\text { Storage Sites }\end{array}$} & $\begin{array}{c}\text { Midpoint of } \\
\text { Time Period of } \\
\text { Maximum } \\
\text { Exposure }\end{array}$ & $\begin{array}{c}\text { Lifetime Dose } \\
\text { (rem/lifetime) }\end{array}$ & $\begin{array}{l}\text { Lifetime Latent } \\
\text { Cancer Fatality }\end{array}$ & $\begin{array}{c}\text { Dominant } \\
\text { Pathway }\end{array}$ & Key Contaminants \\
\hline \multicolumn{5}{|c|}{ Maximally Exposed Individual } \\
\hline Hanford Site & 35 & $2.7 \mathrm{E}+01$ & $1.3 \mathrm{E}-02$ & Air inhalation & $\begin{array}{l}\text { Plutonium-238 } \\
\text { Americium-241 }\end{array}$ \\
\hline $\begin{array}{l}\text { Idaho National } \\
\text { Engineering } \\
\text { Laboratory }\end{array}$ & 1,575 & $1.0 \mathrm{E}+01$ & $5.1 \mathrm{E}-03$ & $\begin{array}{l}\text { Groundwater } \\
\text { ingestion }\end{array}$ & Carbon-14 \\
\hline $\begin{array}{l}\text { Lawrence } \\
\text { Livermore } \\
\text { National } \\
\text { Laboratory }\end{array}$ & 35 & $1.3 \mathrm{E}-02$ & $6.5 \mathrm{E}-06$ & Air inhalation & $\begin{array}{l}\text { Americium-241 } \\
\text { Plutonium-238 }\end{array}$ \\
\hline $\begin{array}{l}\text { Los Alamos } \\
\text { National } \\
\text { Laboratory }\end{array}$ & 665 & $2.0 \mathrm{E}-01$ & $9.8 \mathrm{E}-05$ & Air inhalation & $\begin{array}{l}\text { Plutonium-239 } \\
\text { Americium-241 }\end{array}$ \\
\hline
\end{tabular}


Table 9.3. (contd)

\begin{tabular}{|c|c|c|c|c|c|}
\hline $\begin{array}{c}\text { Major } \\
\text { Generator/ } \\
\text { Storage Sites }\end{array}$ & $\begin{array}{c}\text { Midpoint of } \\
\text { Time Period of } \\
\text { Maximum } \\
\text { Exposure } \\
\end{array}$ & $\begin{array}{l}\text { Lifetime Dose } \\
\text { (rem/lifetime) }\end{array}$ & $\begin{array}{l}\text { Lifetime Latent } \\
\text { Cancer Fatality }\end{array}$ & $\begin{array}{l}\text { Dominant } \\
\text { Pathway }\end{array}$ & Key Contaminants \\
\hline $\begin{array}{l}\text { Oak Ridge } \\
\text { National } \\
\text { Laboratory } \\
\end{array}$ & 105 & $1.5 \mathrm{E}-03$ & $7.5 \mathrm{E}-07$ & \begin{tabular}{|l} 
Groundwater \\
ingestion
\end{tabular} & Plutonium-238 \\
\hline $\begin{array}{l}\text { Rocky Flats } \\
\text { Environmental } \\
\text { Technology Site }\end{array}$ & 35 & $1.5 \mathrm{E}+01$ & $7.2 \mathrm{E}-03$ & Air inhalation & Americium-241 \\
\hline $\begin{array}{l}\text { Savannah River } \\
\text { Site } \\
\end{array}$ & 35 & $5.4 \mathrm{E}+00$ & $2.7 \mathrm{E}-03$ & Air inhalation & \begin{tabular}{|l|} 
Plutonium-238 \\
Americium-241 \\
\end{tabular} \\
\hline \multicolumn{6}{|c|}{ Population } \\
\hline Hanford Site & 35 & $2.7 \mathrm{E}+01$ & $1.3 \mathrm{E}-02$ & $\begin{array}{c}\text { Air inhalation } \\
\text {. } \\
\end{array}$ & \begin{tabular}{|l|} 
Plutonium-238 \\
Plutonium-240 \\
Americium-241 \\
\end{tabular} \\
\hline $\begin{array}{l}\text { Idaho National } \\
\text { Engineering } \\
\text { Laboratory }\end{array}$ & 35 & $3.3 E+02$ & $1.6 \mathrm{E}-01$ & Air inhalation & $\begin{array}{l}\text { Plutonium-238 } \\
\text { Americium-241 }\end{array}$ \\
\hline $\begin{array}{l}\text { Lawrence } \\
\text { Livermore } \\
\text { National } \\
\text { Laboratory }\end{array}$ & 35 & $2.8 \mathrm{E}+01$ & $1.4 \mathrm{E}-02$ & Air inhalation & $\begin{array}{l}\text { Americium-241 } \\
\text { Plutonium-238 }\end{array}$ \\
\hline $\begin{array}{l}\text { Los Alamos } \\
\text { National } \\
\text { Laboratory }\end{array}$ & 35 & $3.5+02$ & $1.7 \mathrm{E}-01$ & Air inhalation & $\begin{array}{l}\text { Plutonium-239 } \\
\text { Americium-241 }\end{array}$ \\
\hline $\begin{array}{l}\text { Oak Ridge } \\
\text { National } \\
\text { Laboratory }\end{array}$ & 35 & $6.4 \mathrm{E}-0 \mathrm{i}$ & $3.2 \mathrm{E}-04$ & Air inhalation & $\begin{array}{l}\text { Americium-241 } \\
\text { Plutonium-238 }\end{array}$ \\
\hline $\begin{array}{l}\text { Rocky Flats } \\
\text { Environmental } \\
\text { Technology Site }\end{array}$ & 665 & $4.2 \mathrm{E}+04$ & $2.1 \mathrm{E}+01$ & Air inhalation & $\begin{array}{l}\text { Plutonium-239 } \\
\text { Plutonium-240 } \\
\text { Americium-241 } \\
\end{array}$ \\
\hline $\begin{array}{l}\text { Savannah River } \\
\text { Site }\end{array}$ & 9,905 . & $1.3 \mathrm{E}+03$ & $6.5 \mathrm{E}-01$ & $\begin{array}{l}\begin{array}{l}\text { Surfacewater } \\
\text { ingestion }\end{array} \\
\end{array}$ & \begin{tabular}{|l|} 
Plutonium-239 \\
Plutonium-240
\end{tabular} \\
\hline
\end{tabular}

rem/lifetime. The resultant estimation of LCFs ranges form 7.5E-07 to 1.3E-02. The highest MEI exposure was estimated at the Hanford Site for the air inhalation pathway, with americium-241 and plutonium-238 being the key contaminants estimated to occur within the first lifetime after loss of institutional control.

The estimated maximum lifetime population risks were estimated from the air and surfacewater pathways. The groundwater pathway was not assumed to be a significant source of offsite drinking water, so it was not considered in the estimation of offsite population risk. The maximum lifetime population radiation dose for all sites (see Table 9.3) ranges from 6.4E-01 to 4.2E+04 personrem/lifetime. The resultant LCFs range from 3.2E-04 to $2.1 \mathrm{E}+01$. The highest risk was estimated at 
RFETS, where the calculated risk was nearly two orders of magnitude higher than any other site. The dominant exposure pathway is via air inhalation for the 9th lifetime (665 yr), with plutonium-239, plutoriam-240, and americium-241 being the key contaminants. The aggregate risk from all sites over 10,000 yr was estimated to result in $2,325 \mathrm{LCFs}$, which is compared to $1,500,000,000$ people from all 7 . sites over the 10,000 -year analysis period.

Summary plots of site-specific radiological risk results for all long-term environmental impact analyses are in provided in Figures 9.1 through 9.4.

\subsubsection{Chemical Carcinogen Impacts}

The maximum lifetime expectation of cancer incidence from chemical carcinogens to an MEI (Table 9.4) ranges from 2.5E-07 to 5.4E-03 over the 7 sites. The highest cancer incidence was estimated for INEL estimated to occur over 3,000 years after loss of institutional control. The predominant impacts at nearly all sites, except for LANL, resulted from ingestion of groundwater containing 1,1,2,2-tetrachloroethane.

The maximum lifetime cancer incidence for exposed populations (see Table 9.4) was estimated to range from $4.2 \mathrm{E}-09$ to $7.4 \mathrm{E}-04$ over the 7 sites. The highest estimated population cancer incidence is expected to occur at RFETS about 500 years after loss of institutional control. The aggregate lifetime cancer incidence over the 7 sites was estimated at 0.25 . Figures 9.5 and 9.6 are summary plots of sitespecific chemical carcinogenic cancer incidence effects to the MEI and population receptors, respectively.

\subsubsection{Noncarcinogen Impacts}

Maximum hazard indexes from chemical noncarcinogens to an MEI (Table 9.5) ranges from 1.5E-04 to 3.2E+00. The highest hazard index was estimated for SRS about 700 years after loss of institutional control. The predominant impact at SRS was ingestion of groundwater containing mercury. Figure 9.7 is a summary plot of site-specific hazard index values to an MEI receptor.

\subsubsection{Summary of Long-Term Impacts from Environmental Release}

The long-term impacts can be separated by the contaminant type (radiological carcinogen, chemical carcinogen, or chemical noncarcinogen) and risk metric (maximum exposed individual or population risk). The following is a summary of the results from the long-term impacts from environmental releases for these different dimensions.

The radiological carcinogenic impacts for the MEI were dominated by the atmospheric inhalation pathway results from suspension of contaminated surface soil soon after the loss of institutional control. The Hanford Site had the highest estimate of LCFs from radionuclides (1.3E-02 from Table 9.3), with SRS, INEL, and RFETS estimated values being within an order-of-magnitude of the Hanford Site values. The key contaminants were plutonium-238 and americium-241. The dominant exposure pathway for the INEL site is estimated to be groundwater ingestion of carbon-14 and the these impacts are estimated 


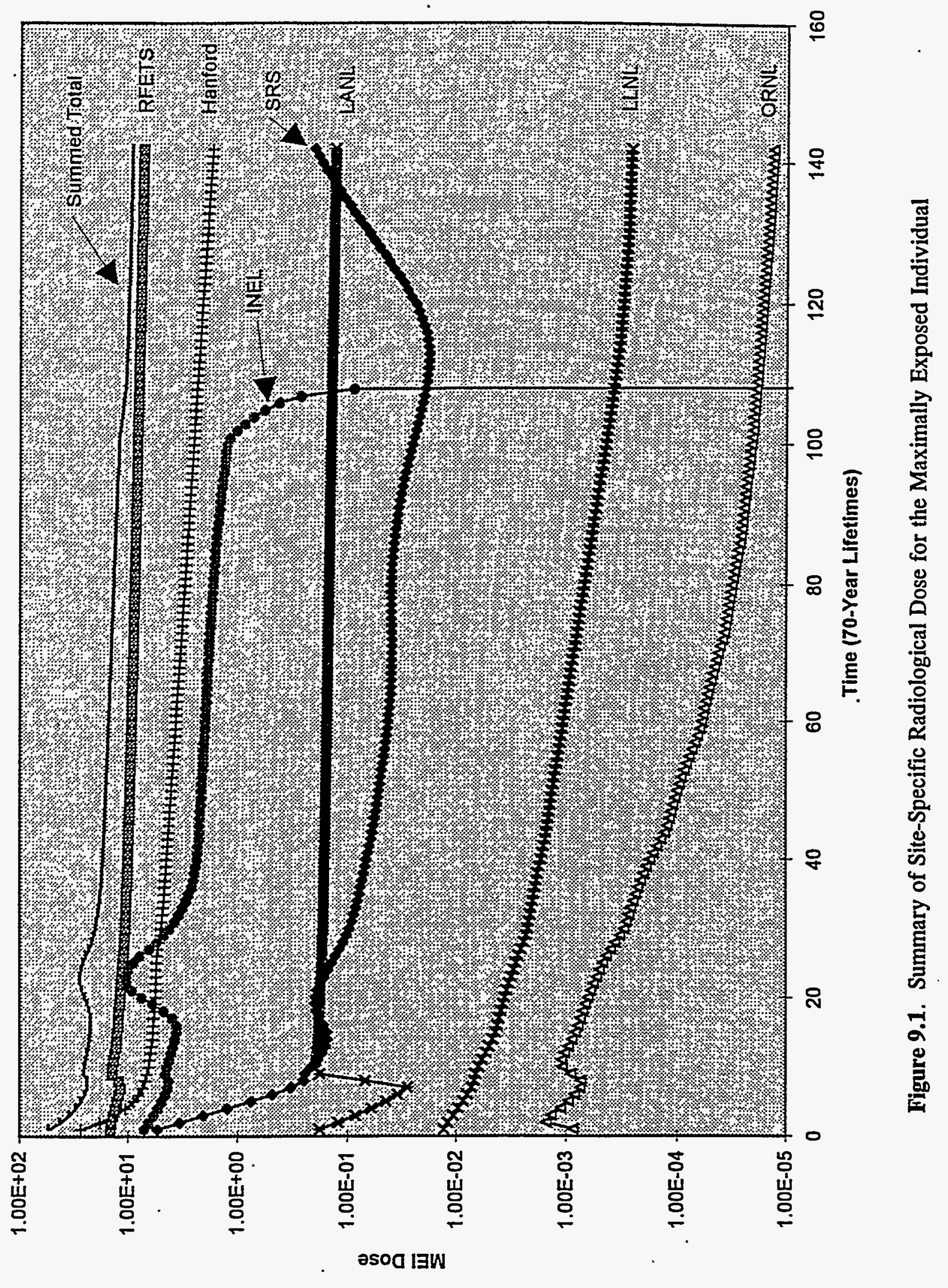




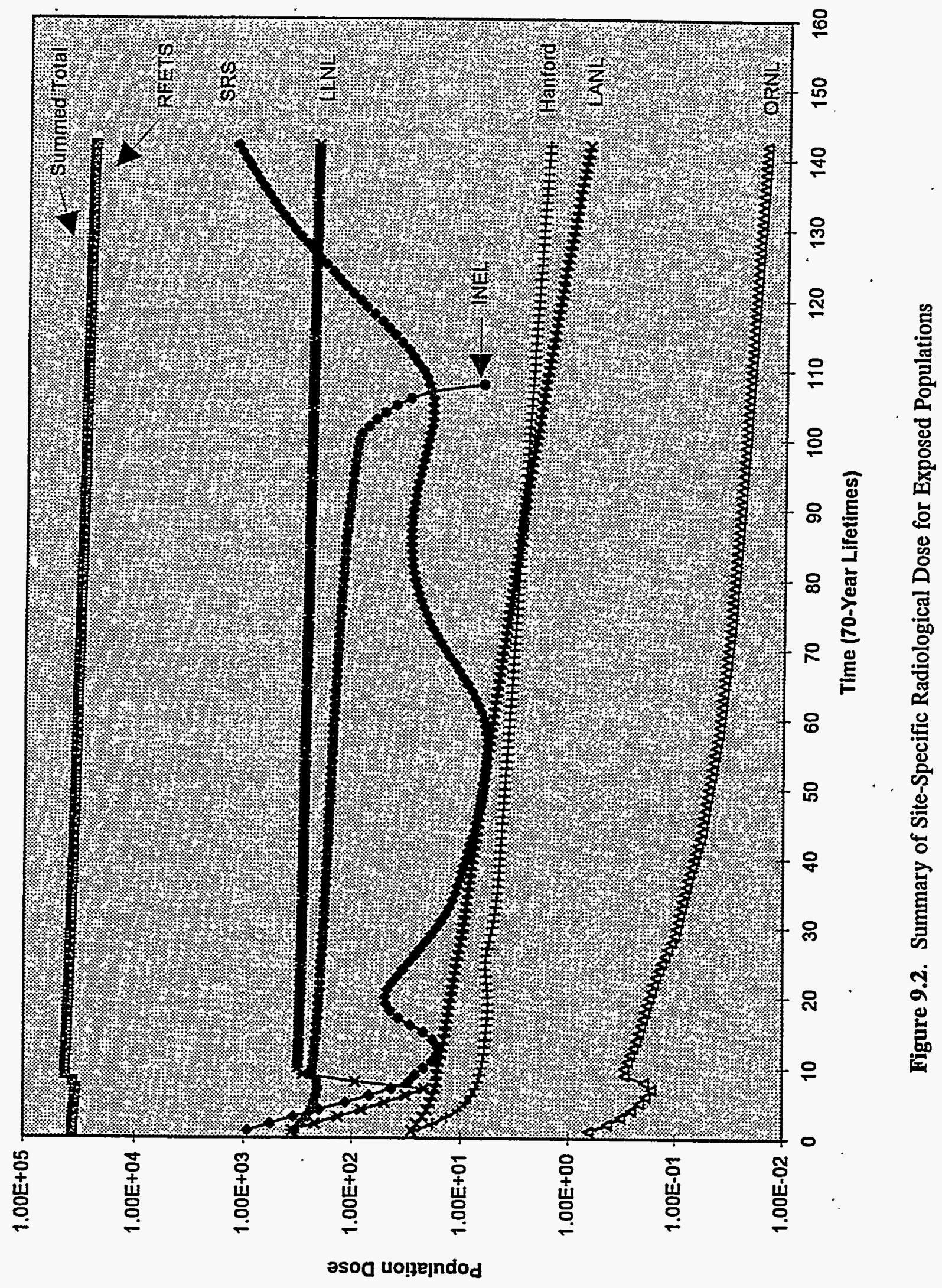


II: 6

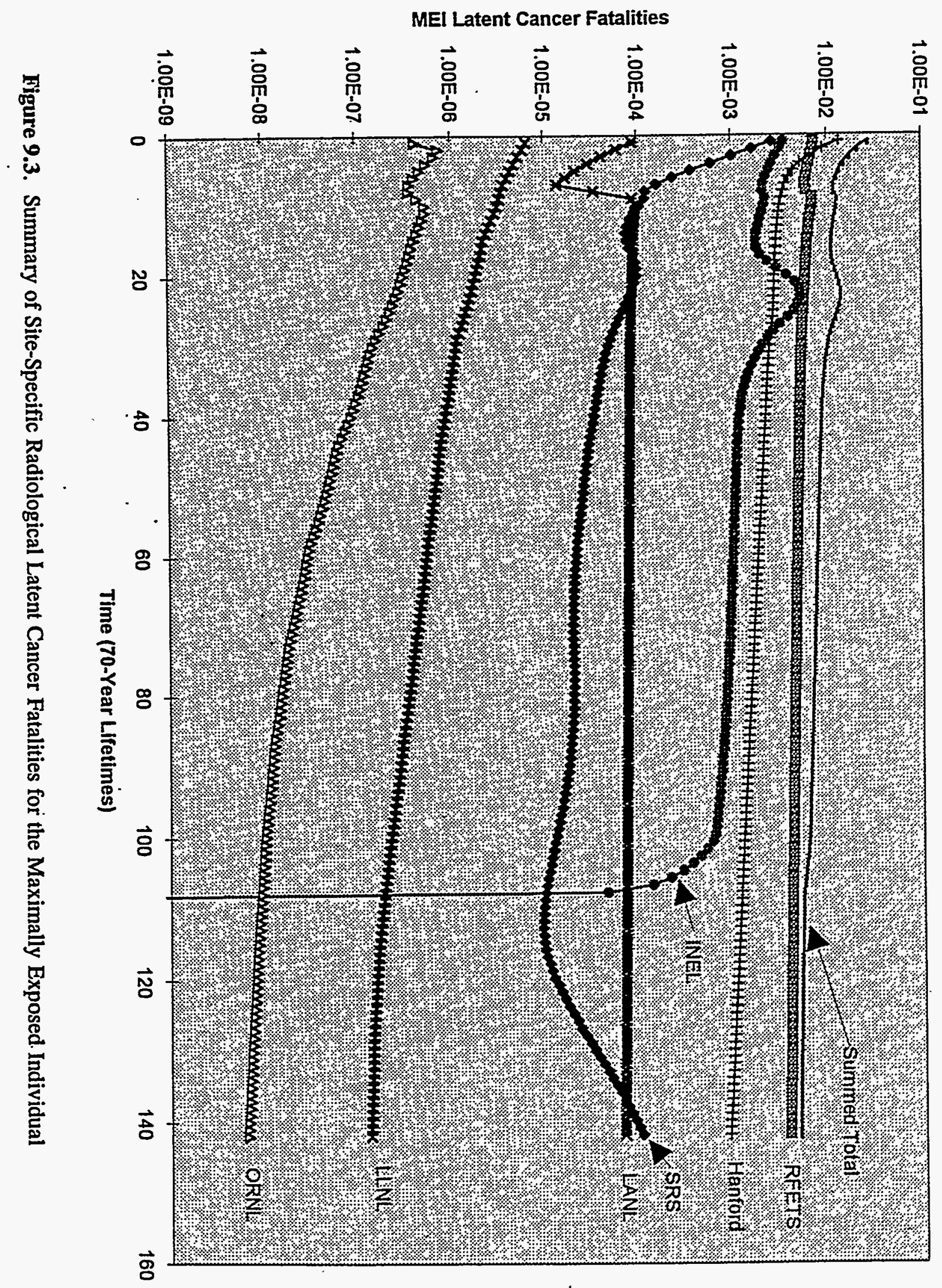




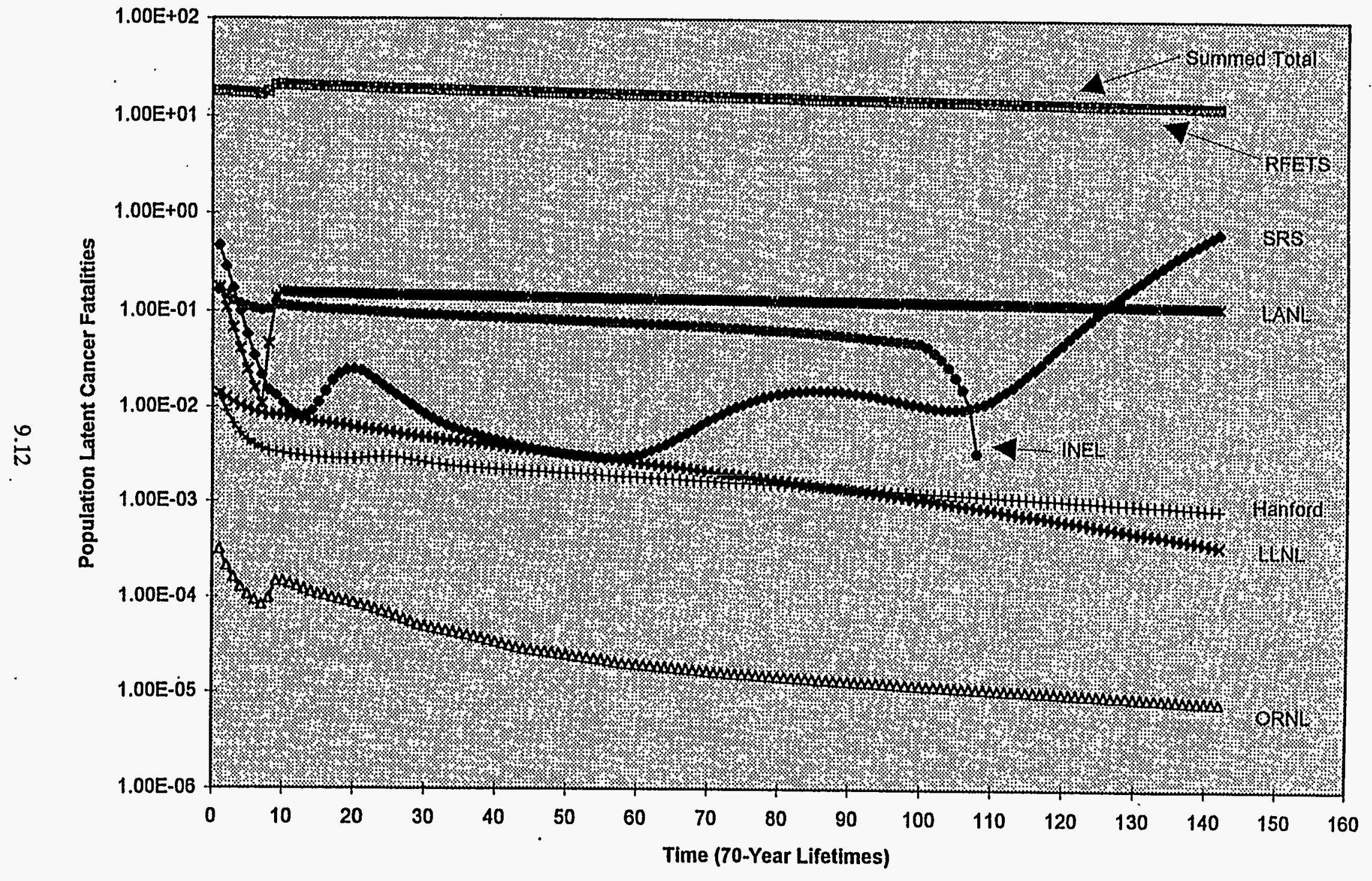

Figure 9.4. Summary of Site-Specific Radiological Latent Cancer Fatalities for the Exposed Population 
Table 9.4. Summary of Nonradioactive Carcinogen Impacts to the Maximally Exposed Individual and Population after Loss of Institutional Control at the Seven Major Generator/ Storage Sites

\begin{tabular}{|c|c|c|c|c|}
\hline $\begin{array}{l}\text { Major Generator/ } \\
\text { Storage Sites }\end{array}$ & $\begin{array}{l}\text { Midpoint of } \\
\text { Time Period } \\
\text { of Maximum } \\
\text { Exposure }\end{array}$ & $\begin{array}{l}\text { Lifetime } \\
\text { Cancer } \\
\text { Incidence }\end{array}$ & $\begin{array}{l}\text { Dominant } \\
\text { Pathway }\end{array}$ & $\begin{array}{c}\text { Key } \\
\text { Contaminants }\end{array}$ \\
\hline \multicolumn{5}{|c|}{ Maximally Exposed Individual } \\
\hline Hanford Site & 1,855 & $2.6 \mathrm{E}-05$ & $\begin{array}{l}\text { Groundwater } \\
\text { ingestion }\end{array}$ & $\begin{array}{l}1,1,2,2- \\
\text { Tetrachloroethane }\end{array}$ \\
\hline $\begin{array}{l}\text { Idaho National } \\
\text { Engineering } \\
\text { Laboratory }\end{array}$ & 3,185 & $5.4 \mathrm{E}-03$ & $\begin{array}{l}\text { Groundwater } \\
\text { ingestion }\end{array}$ & $\begin{array}{l}1,1,2,2- \\
\text { Tetrachloroethane }\end{array}$ \\
\hline $\begin{array}{l}\text { Lawrence } \\
\text { Livermore National } \\
\text { Laboratory }\end{array}$ & 105 & 5.0E-06 & $\begin{array}{l}\text { Groundwater } \\
\text { ingestion }\end{array}$ & $\begin{array}{l}1,1,2,2- \\
\text { Tetrachloroethane }\end{array}$ \\
\hline $\begin{array}{l}\text { Los Alamos } \\
\text { National Laboratory }\end{array}$ & 525 & $2.5 \mathrm{E}-07$ & Air inhalation & $\begin{array}{l}1,1,2,2- \\
\text { Tetrachloroethane }\end{array}$ \\
\hline $\begin{array}{l}\text { Oak Ridge National } \\
\text { Laboratory }\end{array}$ & 35 & $5.9 \mathrm{E}-07$ & $\begin{array}{l}\text { Groundwater } \\
\text { ingestion }\end{array}$ & $\begin{array}{l}1,1,2,2- \\
\text { Tetrachloroethane }\end{array}$ \\
\hline $\begin{array}{l}\text { Rocky Flats } \\
\text { Environmental } \\
\text { Technology Site }\end{array}$ & 2,975 & $3.1 \mathrm{E}-07$ & $\begin{array}{l}\text { Groundwater } \\
\text { ingestion }\end{array}$ & $\begin{array}{l}1,1,2,2- \\
\text { Tetrachloroethane }\end{array}$ \\
\hline Savannah River Site & 35 & $3.6 \mathrm{E}-04$ & $\begin{array}{l}\text { Groundwater } \\
\text { ingestion }\end{array}$ & $\begin{array}{l}1,1,2,2- \\
\text { Tetrachloroethane }\end{array}$ \\
\hline \multicolumn{5}{|c|}{ Population } \\
\hline Hanford Site & 105 & $2.9 E-08$ & Air inhalation & $\begin{array}{l}\text { Beryllium } \\
\text { Cadmium }\end{array}$ \\
\hline $\begin{array}{l}\text { Idaho Natiorial } \\
\text { Engineering } \\
\text { Laboratory }\end{array}$ & 525 & 6.5E-06 & Air inhalation & $\begin{array}{l}1,1,2,2- \\
\text { Tetrachloroethane }\end{array}$ \\
\hline $\begin{array}{l}\text { Lawrence } \\
\text { Livermore National } \\
\text { Laboratory }\end{array}$ & 665 & 2.5E-07 & $\begin{array}{l}\text { Groundwater } \\
\text { ingestion }\end{array}$ & $\begin{array}{l}1,1,2,2- \\
\text { Tetrachloroethane }\end{array}$ \\
\hline $\begin{array}{l}\text { Los Alamos } \\
\text { National Laboratory }\end{array}$ & 525 & 4.7E-04 & Air inhalation & $\begin{array}{l}1,1,2,2 \\
\text { Tetrachloroethane }\end{array}$ \\
\hline
\end{tabular}


Table 9.4. (contd)

\begin{tabular}{|l|c|c|l|l|}
\hline $\begin{array}{l}\text { Major Generator/ } \\
\text { Storage Sites }\end{array}$ & $\begin{array}{c}\text { Midpoint of } \\
\text { Time Period } \\
\text { of Maximum } \\
\text { Exposure }\end{array}$ & $\begin{array}{c}\text { Lifetime } \\
\text { Cancer } \\
\text { Incidence }\end{array}$ & $\begin{array}{c}\text { Dominant } \\
\text { Pathway }\end{array}$ & \multicolumn{1}{c|}{$\begin{array}{c}\text { Key } \\
\text { Contaminants }\end{array}$} \\
\hline $\begin{array}{l}\text { Oak Ridge National } \\
\text { Laboratory }\end{array}$ & 665 & $4.2 \mathrm{E}-09$ & $\begin{array}{l}\text { Surfacewater } \\
\text { ingestion }\end{array}$ & $\begin{array}{l}1,1,2,2- \\
\text { Tetrachloroethane }\end{array}$ \\
\hline $\begin{array}{l}\text { Rocky Flats } \\
\text { Environmentál } \\
\text { Technology Site }\end{array}$ & 525 & $7.4 \mathrm{E}-04$ & Air inhalation & $\begin{array}{l}1,1,2,2- \\
\text { Tetrachloroethane }\end{array}$ \\
\hline Savannah River Site & 665 & $1.1 \mathrm{E}-07$ & $\begin{array}{l}\text { Surfacewater } \\
\text { ingestion }\end{array}$ & Beryllium \\
\hline
\end{tabular}

to occur more than 1,500 years after the loss of institutional control of the site. Three sites (LLNL, LANL, and ORNL) have estimated maximum lifetime MEI values that are near or less than 1.0E-06 cancer incidence reference level.

For radiological carcinogenic impacts for the surrounding population, the dominant pathway was again the atmospheric inhalation pathway resulting from suspension of contaminated surface soil soon after the loss of institutional control. The key contaminants were plutonium-238, plutonium-240, and americium-241. The RFETS had the highest estimate of LCFs from radionuclides (2.1E+01 from Table 9.3) occurring more that 500 years after loss of institutional control. This delay in the maximum population impact is caused by the summation of soil contamination and the failure of the cement waste form. RFETS was the only site that had estimated LCF values greater than 1.0 , indicating that at least one person would potentially die from TRU waste for that lifetime. The other site were at least 2 orders-of-magnitude less the population risk estimates from the RFETS. The SRS has the surfacewater pathway as the dominant route with the impacts estimated to occur almost 10,000 years after loss of institutional control.

For chemical carcinogenic impacts to the MEI, most of the site impacts were estimated to occur from the groundwater pathway, with the INEL site having the highest estimated impacts (5.4E-03 from Table 9.4). The key contaminant at all sites was 1,1,2,2-tetrachloroethane. These impacts are estimated to occur more than 3,000 years after the loss of institutional control. Four sites (INEL, SRS, Hanford Site, and LLNL) have maximum lifetime MEI values that are near or less than $1.0 \mathrm{E}-06$ cancer incidence reference level but with estimates of occurrence varying from 100 years to over 3,000 years after the loss of institutional control.

For chemical carcinogenic impacts to the surrounding population, 5 sites (Hanford Site, INEL, . LANL, LLNL, and RFETS) have atmospheric inhalation as the dominant pathway and 2 sites (ORNL 


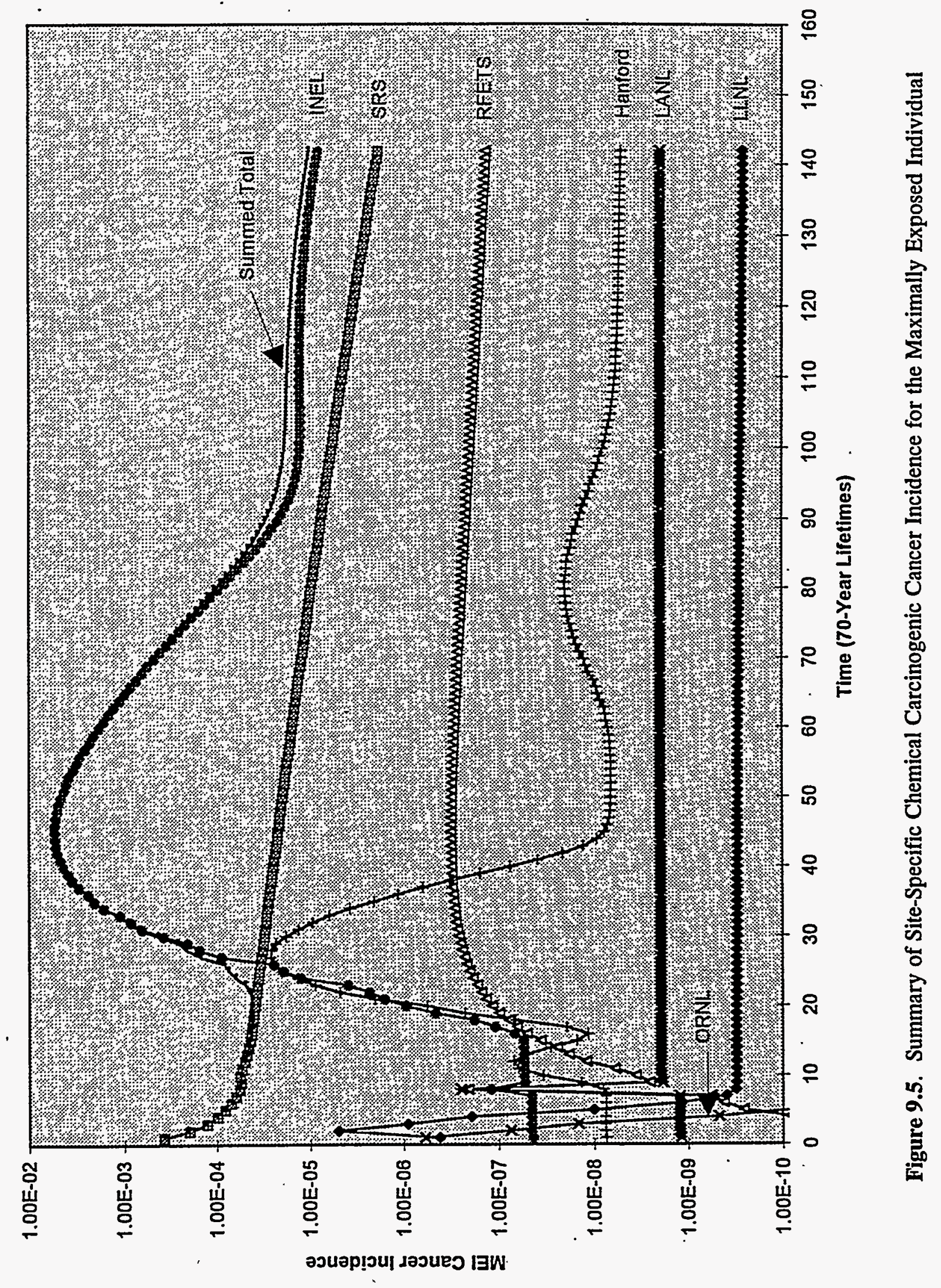




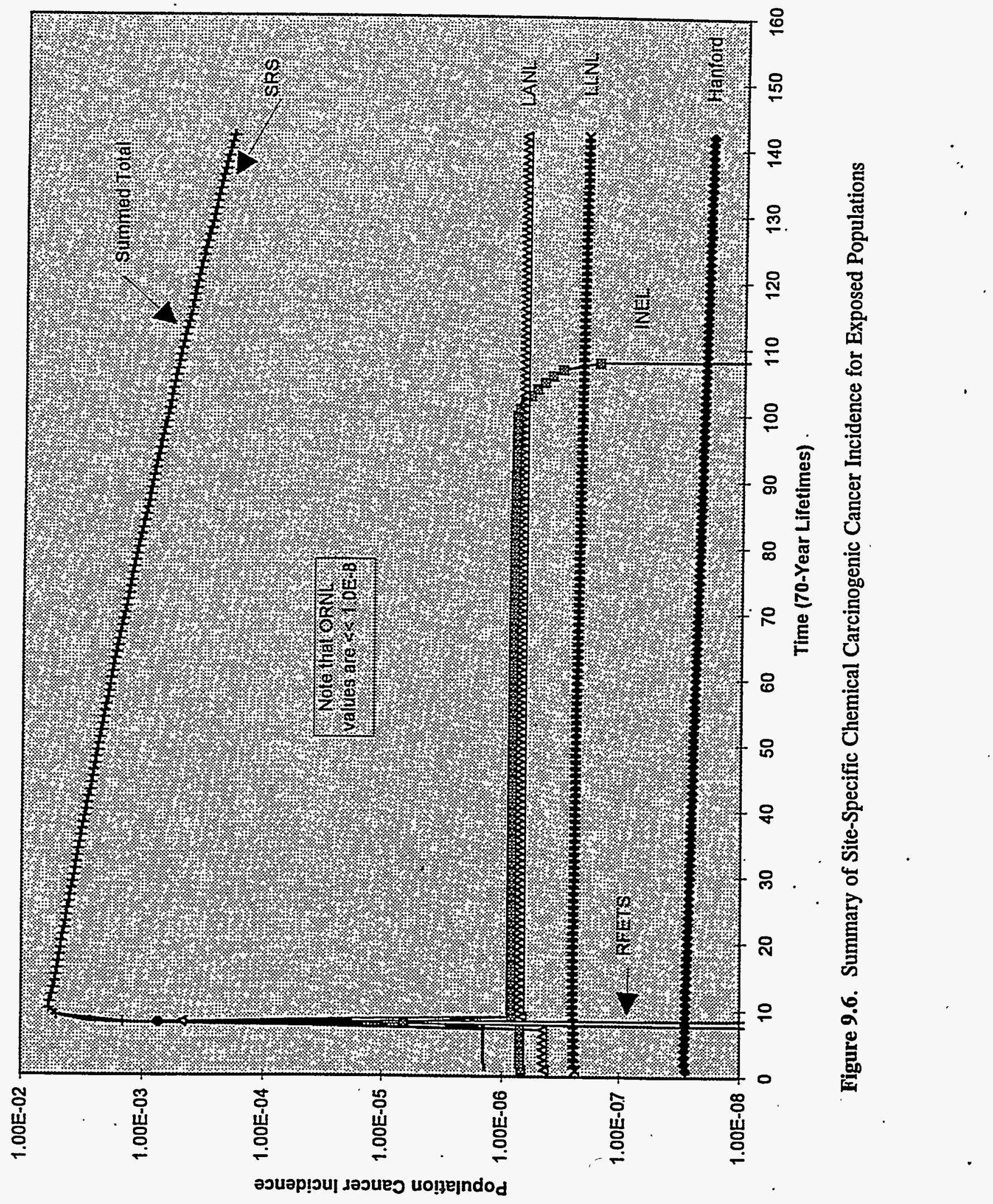


Table 9.5.Summary of Noncarcinogen Impacts to the Maximally Exposed Individual after Loss of Institutional Control at the Seven Major Generator/Storage Sites

\begin{tabular}{|l|c|c|l|l|}
\hline $\begin{array}{c}\text { Major Generator/ } \\
\text { Storage Sites }\end{array}$ & $\begin{array}{c}\text { Midpoint of } \\
\text { Time Period } \\
\text { of Maximum } \\
\text { Exposure }\end{array}$ & $\begin{array}{c}\text { Maximum } \\
\text { Hazard } \\
\text { Index }\end{array}$ & $\begin{array}{c}\text { Dominate } \\
\text { Pathway }\end{array}$ & \multicolumn{1}{|c|}{$\begin{array}{c}\text { Key } \\
\text { Chemical }\end{array}$} \\
\hline Hanford Site & 805 & $1.7 \mathrm{E}-02$ & $\begin{array}{l}\text { Groundwater } \\
\text { ingestion }\end{array}$ & Mercury \\
\hline $\begin{array}{l}\text { Idaho National } \\
\text { Engineering Laboratory }\end{array}$ & 7,035 & $3.7 \mathrm{E}-01$ & $\begin{array}{l}\text { Groundwater } \\
\text { ingestion }\end{array}$ & $\begin{array}{l}\text { Carbon } \\
\text { tetrachloride }\end{array}$ \\
\hline $\begin{array}{l}\text { Lawrence Livermore } \\
\text { National Laboratory }\end{array}$ & 315 & $6.2 \mathrm{E}-04$ & $\begin{array}{l}\text { Groundwater } \\
\text { ingestion }\end{array}$ & $\begin{array}{l}\text { Carbon } \\
\text { tetrachloride }\end{array}$ \\
\hline $\begin{array}{l}\text { Los Alamos National } \\
\text { Laboratory }\end{array}$ & 665 & $3.1 \mathrm{E}-03$ & $\begin{array}{l}\text { Resuspended } \\
\text { soil } \\
\text { ingestion }\end{array}$ & Mercury \\
\hline $\begin{array}{l}\text { Oak Ridge National } \\
\text { Laboratory }\end{array}$ & 1,295 & $3.2 \mathrm{E}-04$ & $\begin{array}{l}\text { Groundwater } \\
\text { ingestion }\end{array}$ & Mercury \\
\hline $\begin{array}{l}\text { Rocky Flats } \\
\text { Environmental } \\
\text { Technology Site }\end{array}$ & 875 & $1.5 \mathrm{E}-04$. & Air ingestion & $\begin{array}{l}\text { Carbon } \\
\text { tetrachloride }\end{array}$ \\
\hline Savannah River Site & 735 & $3.2 \mathrm{E}+00$ & $\begin{array}{l}\text { Groundwater } \\
\text { Ingestion }\end{array}$ & Mercury \\
\hline
\end{tabular}

and SRS) have surfacewater ingestion as the dominant pathway. The key contaminants were 1,1,2,2tetrachloroethane, beryllium, and cadmium. RFETS has the highest estimated cancer incidence impacts (7.4E-04 from Table 9.4) but the value is far below 1.0 impacts within the population. These impacts are estimated to occur more than $\mathbf{5 0 0}$ years after the loss of institutional control.

- For chemical noncarcinogenic impacts to the MEI, most of the site impacts were estimated to occur from the groundwater pathway, with the SRS having the highest estimated impacts $(3.2 \mathrm{E}+00$ from Table 9.5). These impacts are estimated to occur more than 700 years after the loss of institutional control. The key contaminant was mercury. All other sites have maximum lifetime MEI values less the reference value of 1.0 . 


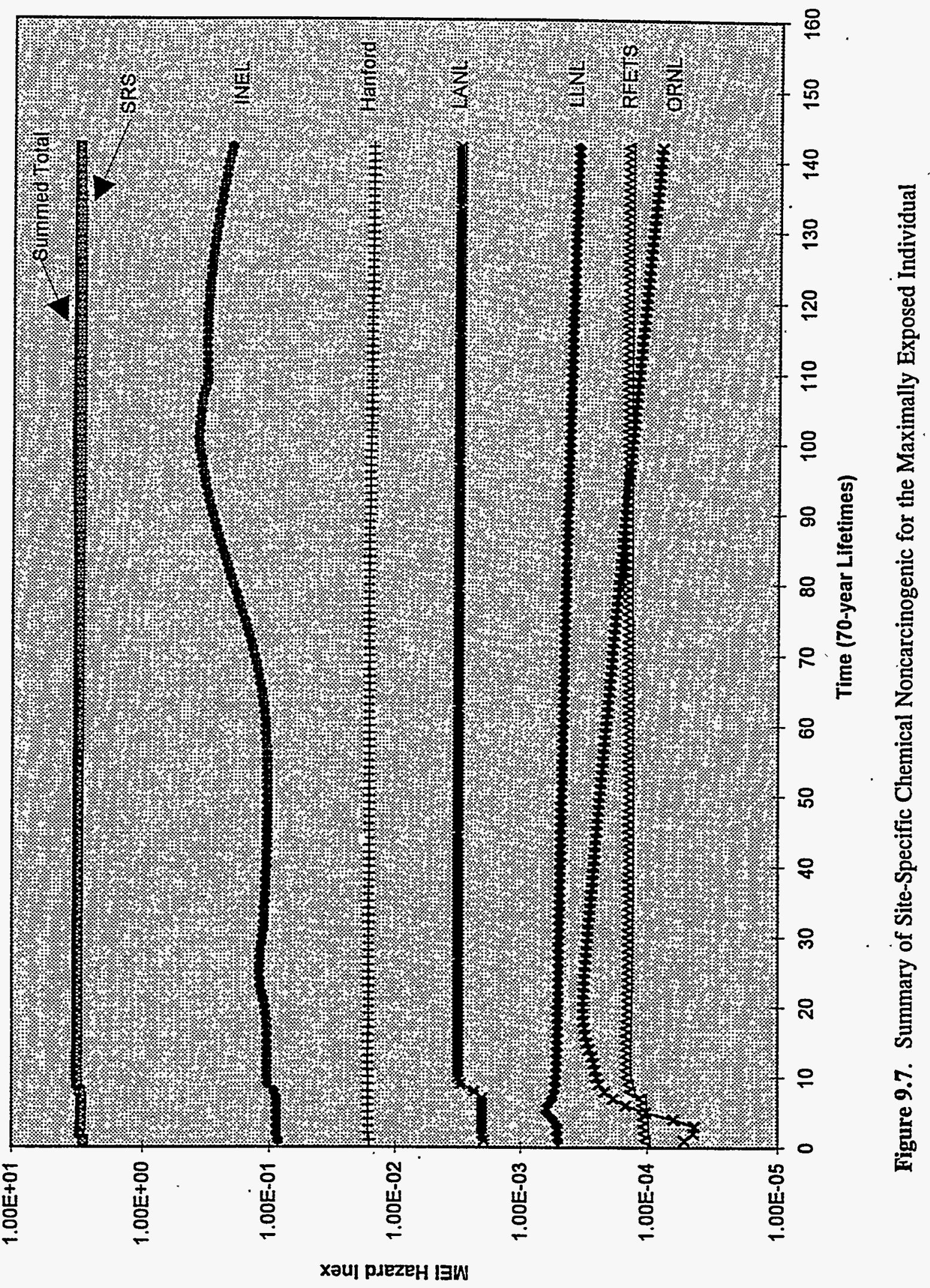


In general, the long-term impacts to MEI endpoints have a potential to be significant for radionuclides, chemical carcinogens, and chemical noncarcinogens. The population impacts seem to be minimal with only RFETS having population impacts greater than $1.0(2.1 \mathrm{E}+01$ from Table 9.3). The aggregate LCFs for all radionuclides from all sites over the 10,000 analysis period is 2,325 within a population size of $1,560,912,782$. (sum of the atmospheric and surfacewater populations from all 7 sites multiplied by 143 generations). The population impacts from chemical carcinogens over the same aggregate population is less that 1.0 ( 0.25 cancer incidences). 



\subsection{References}

Arnett, M. W., L. K. Karapatakis, and A. R. Mamatey (eds.). 1993. Savannah River Site Environmental Report for 1992. WSRC-TR-93-075, Westinghouse Savannah River Company, Aiken, South Carolina.

Arnett, M. W., A. R. Mametey, and D. Spitzer.(eds.). 1995. Savannah River Site Environmental Report for 1994. WSCR-TR-95-075, Westinghouse Savannah River Company, Aiken, South Carolina.

Barraclough, J. T., B. D. Lewis, and R. G. Jensen, 1981. Hydrologic Conditions at the Idaho National Engineering Laboratory; Idaho, Emphasis: 1974-1978. IDO-22060, U. S. Geological Survey Water Resources Investigations Open File Report 81-526, Idaho Falls, Idaho.

Bergenback, B., B. P. Blaylock, J. L. Legg, P. Pehlman, R, Phillippi, P. Ratledge, P. A. Scofield, M. A. Simek, C. Smith, C. C. Travis, and D. Wollert. 1995. Waste Management Programmatic Environmental Impact Statement Methodology for Estimating Human Health Risks. ORR-6864, Oak Ridge National Laboratory, University of Tennessee, Office of Environmental Compliance and Documentation, and Midwest Technical, Inc., Oak Ridge, Tennessee.

Biological Effects of Ionizing Radiation. 1980. The Effects on Populations of Exposure to Low Levels of Ionizing Radiation: 1980. Report III. National Academy Press, Washington, D.C.

Blaylock, B., I. C. Datskou, J. M. Morris, P. Pehlman, R. Phillippi, C. C. Travis, and D. Wollert. 1995. U. S. Department of Energy Public and On-Site Population Health Risk Evaluation Methodology for Assessing Risks Associated with Environmental Restoration and Waste Management. ORR-6832, Oak Ridge National Laboratory, Center for Risk Management, Oak Ridge, Tennessee.

Buck, J. W., G. Whelan, J. G. Droppo, Jr., D. L. Strenge, K. J. Castleton, J. P. McDonald, C. Sato, and G. P. Streile. 1995. Multimedia Environmental Pollutant Assessment System (MEPAS) Application Guidance: Guidelines for Evaluating MEPAS Input Parameters for Version 3.1. PNL-10395, Pacific Northwest Laboratory, Richland, Washington.

Connelly, M. P., B. H. Ford, and J. V. Borgese. 1992. Hydrogeologic Model for the 200 West Groundwater Aggregate Area. WHC-SD-EN-TI-014, Westinghouse Hanford Company, Richland, Washington.

Dirkes, R. L., and R. W. Hanf (eds.). 1995. Hanford Site Environmental Report for Calendar Year 1994. PNL-10574, Pacific Northwest Laboratory, Richland, Washington.

10.1 
Droppo J. G., Jr., G. Whelan, J. W. Buck, D. L. Strenge, B. L. Hoopes, and M. B. Walter. 1989a. Supplemental Mathematical Formulations: The Multimedia Environmental Pollutant Assessment System (MEPAS). PNL-7201, Pacific Northwest Laboratory, Richland, Washington."

Droppo J. G. Jr., D. L. Strenge, J. W. Buck, B. L. Hoopes, R. D. Brockhaus, M. B. Walter and, G. Whelan. 1989b. Multimedia Environmental Pollutant Assessment System (MEPAS) Application Guidance Volume 1 - User's Guide. PNL-7216, Pacific Northwest Laboratory, Richland, Washington.

Holdren, G. R., S. M. Goodwin, C. S. Glantz, J. R. Rustad, L. K. Berg, R. Schalla, K. Dellinger, J. A. Schramke, and C. J. Fosmire. 1995. Environmental Settings for Selected U. S. Department of Energy Installations - Support Information for the Programmatic Environmental Impact Statement and the Baseline Environmental Management Report. PNL-10550, Pacific Northwest Laboratory, Richland, Washington.

International Commission on Radiation Protection. 1991. 1990 Recommendations of the International Commission on Radiation Protection. Publication 60, Pergamon Press, New York.

Los Alamos National Laboratory (LANL). 1992. Installation Work Plan for Environmental Restoration, Rev. 2. LA-UR-92-3795, Los Alamos, New Mexico.

Los Alamos National Laboratory (LANL). 1993. RFI Work Plan for Operable Unit 1098. Los Alamos, New Mexico.

Lewis, B. D., and R. G. Jensen. 1985. Hydrologic Conditions at the Idaho National Engineering Laboratory, Idaho, 1979-1981 Update. U. S. Geological Survey Water Resources Investigations Atlas HA-674 (2 sheets), Idaho Falls, Idaho.

Martin Marietta Energy Systems, Inc. 1989. Oak Ridge Reservation Environmental Report for 1988, Vol. 1: Narrative, Summary, Conclusions. ES/ESH-8/V1, Environmental and Safety Activities, Oak Ridge, Tennessee.

Martin Marietta Energy Systems, Inc. 1994. Oak Ridge Reservation Annual Site Environmental Report for 1993. ES/ESH-47, Oak Ridge, Tennessee.

Moore, G. K. and L. E. Toran. 1992. Supplement to a Hydrologic Framework for the Oak Ridge Reservation, Oak Ridge, Tennessee. ORR/TM-12191, Oak Ridge National Laboratory, Oak Ridge, Tennessee.

Napier, B. A., R. A. Peloquin, D: L. Strenge, and J. V. Ramsdell. 1988. GENII - The Hanford . Environmental Radiation Dosimetry Software System. PNL-6584, 3 vols., Pacific Northwest Laboratory, Richland, Washington. 
National Institute for Occupational Safety and Health. 1996. NIOSH Pocket Guide to Chemical Hazards, in TOMES (R) - Toxicological, Occupational Medicine, and Environmental Series (CD-ROM), Database Used: NIOSH Pocket Guide. Washington, D.C.

Newcomer, D. R., K. D. Pohlod, and J. P. McDonald. 1992. Water-Table Elevation on the Hanford Site and Outlying Areas, 1991. PNL-8122, Pacific Northwest Laboratory, Richland, Washington.

Pacific Northwest Laboratory. 1992. Hanford Site Environmental Report for Calendar Year 1991. PNL-8148, Richland, Washington.

Streile, G. P., K. D. Shields, J. L. Stroh, L. M. Bagaasen, G. Whelan, J. P. McDonald, J. G. Droppo, and J. W. Buck. .1996. The Multimedia Environmental Pollutant Assessment System (MEPAS): Source-Term Release Formulations. PNNL-11248, Pacific Northwest National Laboratory, Richland, Washington.

Strenge, D. L., and P. J. Chamberlain II. 1995. Multimedia Environmental Pollutant Assessment System (MEPAS): Exposure Pathways and Human Health Impact Assessment Models. PNL-10523, Pacific Northwest Laboratory, Richland, Washington.

Strenge, D. L., and S. R. Peterson. 1989. Chemical Databases for the Multimedia Environmental Pollutant Assessment System (MEPAS); Version I. PNL-7145, Pacific Northwest Laboratory, Richland, Washington.

Thorne, P. D., and M. A. Chamness. 1992. Status Report of the Development of a Three-Dimensional Conceptual Model for the Hanford Site, Unconfined Aquifer System. PNL-8332, Pacific Northwest Laboratory, Richland, Washington.

Thorne, P. D., and D. R. Newcomer. 1992. Summary and Evaluation of Available Hydraulic Property Data for the Hanford Site. PNL-8337, Pacific Northwest Laboratory, Richland, Washington

U.S. Department of Energy (DOE). 1979. Final Environmental.Impact Statement, Los Alamos Scientific Laboratory Site. DOE/EIS-0018, Washington, D.C.

U.S. Department of Energy (DOE). 1980. Final Environmental Impact Statement, Waste Isolation Pilot Plant. DOE/EIS-0026-F, Albuquerque, New Mexico.

U.S. Department of Energy (DOE). 1986. 'Safety Analysis for the Radioactive Waste Management Complex at the Idaho National Engineering Laboratory. WM-PD-86-011, Idaho National Engineering Laboratory, Idaho Falls, Idaho.

U.S. Department of Energy (DOE). 1987. Final Environmental Impact Statement - Disposal of Hanford Defense High-Level, Transuranic and Tank Wastes, Hanford Site, Richland, Washington. DOE/EIS-0113 (5 volumes), Richland, Washington. 
U.S. Department of Energy (DOE). 1988. Environmental Assessment, Management Activities for Retrieved and Newly-Generated Transuranic Waste, Savannah River Plant. DOE/EA-0315, Aiken, South Carolina.

U.S. Department of Ėnergy (DOE). 1994. Integrated Data Base Report-1994: U.S. Spent Nuclear Fuel and Radioactive Waste Inventories, Projections, and Characteristics. DOE/RW-0006, Revision 11, Oak Ridge National Laboratory, Oak Ridge, Tennessee.

U.S. Department of Energy (DOE). 1995a. Draft. Waste Management Programmatic Environmental Impact Statement for Managing Treatment, Storage, and Disposal of Radioactive and Hazardous Wastes. DOE/EIS-0200-XX, Office of Environmental Management, Washington D.C.

U.S. Department of Energy (DOE). 1995b. WIPP Transuranic Waste Baseline Inventory Report, Revision 2. DOE/CAO-95-1121, Carlsbad, New Mexico.

U.S. Department of Energy (DOE). 1995c. Waste Isolation Pilot Plant Safety Analysis Report. DOE/WIPP-95-2065, Revision 1, November, Carlsbad, New Mexico.

U.S. Department of Energy (DOE). 1996a. Draft. No Migration Variance Petition. Carlsbad, New Mexico.

U.S. Department of Energy (DOE). 1996b. Comment Responses and Revisions to the Resource Conservation and Recovery Act Part B Permit Application. DOE/WIPP 91-005, Revision 5.2, January, Carlsbad, New Mexico.

U.S. Environmental Protection Agency (EPA). 1989. Risk Assessment Guidance to Superfund (Volume 1), Human Health Evaluation Manual (Part A), Interim Final. EPA/540/1-89/002, Office of Emergency and Remedial Response, Washington, D.C..

Whelạn, G., D. L. Strenge, J. G. Droppo, Jr., and B. L. Steelman. 1987. The Remedial Action Priority System (RAPS): Mathematical Formulations. PNL-6200, Pacific Northwest Laboratory, Richland, Washington.

Whelan, G., J. W. Buck, and A. Nazarali. 1994. "Modular Risk Analysis for Assessing Multiple Waste Sites." In Proceedings of the U. S. Department of Energy Integrated Planning Workshop. PNL-SA-24239, presented to U. S. Department of Energy, Richland, Washington.

Whelan, G., J. W. Buck, K. J. Castleton, J. P. McDonald, C. Sato, G. M. Gelston, A. deHamer, R. J. Serne, S. K. Wurstner, and R. N. Kickert. 1995. Unit Environmental Transport Assessment of Contaminants from Hanford's Past-Practice Waste Sites. PNL-10233, Pacific Northwest Laboratory, Richland, Washington. 
Appendix A

Contaminant Inventory Data 


\section{Appendix A}

\section{Contaminant Inventory Data}

This appendix contains tables of contaminant inventory data for each site. These tables are broken down by contaminant type (radioactive, organic, and inorganic) and waste type (contact handled and remote handled). Organic contaminant head-space concentrations and inorganic contaminant concentrations are also presented. 
Table A.1. Radionuclide Inventories (Ci) for Stored CH TRU Waste in 1995

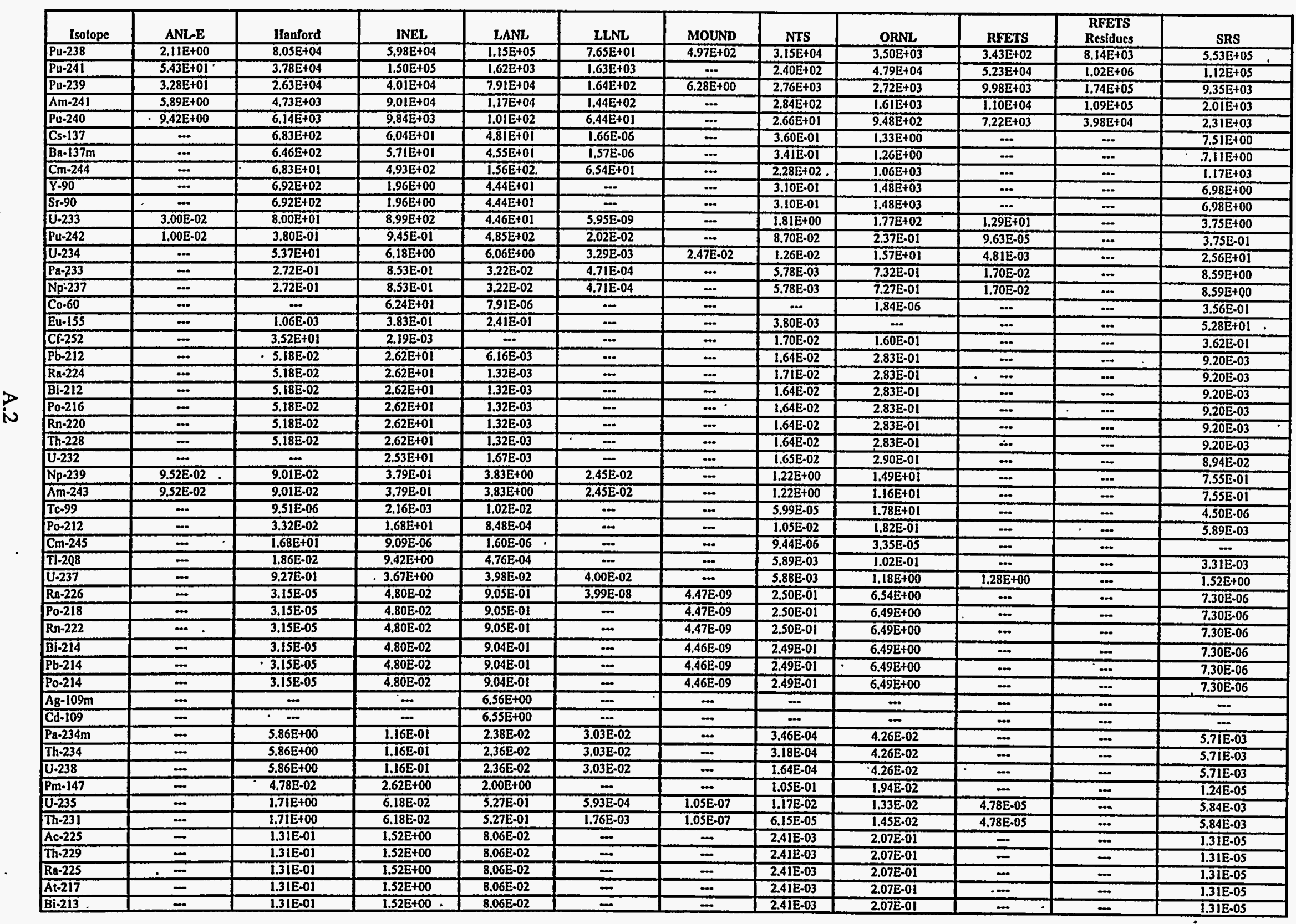


Table A.1. (Contd)

\begin{tabular}{|c|c|c|c|c|c|c|c|c|c|c|c|}
\hline Isolope & ANLE & Hanford & INEL & LANL & LLNL & MOUND & NTS & ORNL & RFETS & $\begin{array}{l}\text { RFETS } \\
\text { Resldues }\end{array}$ & SRS \\
\hline$\overline{F r-221}$ & $\ldots$ & $1.31 \mathrm{E}-01$ & $1.52 \mathrm{E}+00$ & $8.06 \mathrm{E}-02$ & - & - & $2.41 E-03$ & $2.07 \mathrm{E}-01$ & - & - & $1.31 \mathrm{E}-05$ \\
\hline $\mathrm{Pb}-209$ & $=$ & $1.31 \mathrm{E}-01$ & $1.52 E+00$ & $8.06 \mathrm{E}-02$ & $=$ & 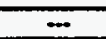 & $2.41 E-03$ & $2.07 E-01$ & - & - & i.31E-05 \\
\hline Po.213 & $\ldots$ & $1.28 \mathrm{E}-01$ & $1.49 \mathrm{E}+00$ & $7.89 \mathrm{E}-02$ & - & - & $2.36 \mathrm{E}-03$ & $2.02 \mathrm{E}=01$ & - & - & $-1.28 \mathrm{E}-05$ \\
\hline C. 14 & $\cdots$ & $1.60 \mathrm{E}+00$ & $1.66 \mathrm{E}-01$ & $2.00 \mathrm{E}-07$ & $=$ & 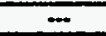 & $2.50 \mathrm{E}-0.4$ & - & 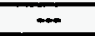 & $\cdots$ & - \\
\hline$B i-210$ & - & $5.30 \mathrm{E}-06$ & $2.70 \mathrm{E}-02$ & $2.80 \mathrm{E}-01$ & - & $5.20 \mathrm{E}-10$ & $6.69 \mathrm{E}-02$ & $1.26 \mathrm{E}+00$ & $\cdots$ & - & $1.11 \mathrm{E}-06$ \\
\hline Po.210 & $=$ & $5.30 \mathrm{E}-06$ & $2.70 \mathrm{E}-02$ & $2.80 \mathrm{E}-01$ & $\overline{-}$ & $5.20 \mathrm{E}-10$ & $6.69 \mathrm{E}-02$ & $1.26 \mathrm{E}+00$ & $\ldots$ & $=$ & 1.11E.06 \\
\hline Pb.210 & $=$ & $5.30 \mathrm{E}-06$ & $2.70 \mathrm{E}-02$ & $2.80 \mathrm{E}-01$ & $\cdots$ & $5.20 \mathrm{E}-10$ & $6.69 \mathrm{E}-02$ & $1.26 \mathrm{E}+00$ & - & $=$ & $.1 .11 E-06$ \\
\hline Eu-152 & - & $7.34 \mathrm{E}-07$ & $1.62 \mathrm{E}-01$ & $4.18 \mathrm{E}-04$ & $1.33 \mathrm{E}-06$ & $\cdots$ & $1.06 E+00$ & $6.18 \mathrm{E}-04$ & $\ldots$ & $\ldots$ & $\ldots$ \\
\hline $\mathrm{Cm}-243$ & - & $1.52 \mathrm{E}-02$ & $=$ & $1.11 E+00$ & $-\infty$ & $\cdots$ & $\cdots$ & $=$ & $=$ & $=$ & $\cdots$ \\
\hline Eu-154 & - & $6.22 \mathrm{E} \cdot 05$ & $6.43 \mathrm{E}-01$ & $2.45 \mathrm{E}-02$ & $5.25 \mathrm{E}-07$ & - & $4.28 \mathrm{E}-01$ & $\ldots$ & $\cdots$ & $\cdots$ & $2.84 \mathrm{E}-04$ \\
\hline
\end{tabular}


Table A.2. Radionuclide Inventories (Ci) for Stored RH TRU Waste in $1995^{(a)}$

\begin{tabular}{|c|c|c|c|c|}
\hline Isotope & Hanford & INEL & LANL & ORNL \\
\hline Y-90 & $6.46 \mathrm{E}+03$ & $1.70 \mathrm{E}+03$ & $1.24 \mathrm{E}+02$ & $3.52 \mathrm{E}+04$ \\
\hline Sr-90 & $6.46 \mathrm{E}+03$ & $1.70 \mathrm{E}+03$ & $1.24 \mathrm{E}+02$ & $3.52 \mathrm{E}+04$ \\
\hline Cs-137 & $6.98 \mathrm{E}+03$ & $1.90 \mathrm{E}+03$ & $1.35 \mathrm{E}+02$ & $9.78 \mathrm{E}+03$ \\
\hline $\mathrm{Ba}-137 \mathrm{~m}$ & $6.61 E+03$ & $1.80 \mathrm{E}+03$ & $1.28 \mathrm{E}+02$ & $9.25 \mathrm{E}+03$ \\
\hline $\mathrm{Pu}-241$ & $4.67 \mathrm{E}+03$ & $4.81 E+01$ & $\cdots$ & $3.97 \mathrm{E}-07$ \\
\hline Eu-152 & - & $1.14 \mathrm{E}-01$ & $5.09 \mathrm{E}-04$ & $3.66 \mathrm{E}+03$ \\
\hline Eu-154 & - & $7.90 \mathrm{E}-01$ & $3.50 \mathrm{E}-02$ & $1.77 \mathrm{E}+03$ \\
\hline $\mathrm{Cm}-244$ & $\ldots$ & $9.63 \mathrm{E}-02$ & $\ldots$ & $9.44 \mathrm{E}+02$ \\
\hline Co-60 & $3.36 \mathrm{E}+02$ & $1.30 \mathrm{E}+01$ & $4.17 \mathrm{E}+00$ & $6.14 \mathrm{E}+02$ \\
\hline $\mathrm{Pu}-239$ & $3.35 \mathrm{E}+02$ & $2.98 \mathrm{E}+01$ & $9.28 \mathrm{E}+01$ & $9.85 \mathrm{E}+01$ \\
\hline Am-241 & $1.93 E+02$ & $4.68 \mathrm{E}+01$ & - & $2.42 \mathrm{E}+02$ \\
\hline Eu-155 & - & $3.35 \mathrm{E}-01$ & $1.77 \mathrm{E}+00$ & $3.51 E+02$ \\
\hline $\mathrm{Pu}-240$ & $1.67 \mathrm{E}+02$ & $2.48 \mathrm{E}+01$ & - & $1.07 \mathrm{E}+00$ \\
\hline Th-231 & $1.46 \mathrm{E}-01$ & $6.42 \mathrm{E}-03$ & $8.78 \mathrm{E}-03$ & $1.86 \mathrm{E}+02$ \\
\hline U-235 & $1.46 \mathrm{E}-01$ & $5.38 \mathrm{E}-03$ & $8.78 \mathrm{E}-03$ & $1.86 \mathrm{E}+02$ \\
\hline $\mathrm{Pu}-238$ & $4.67 \mathrm{E}+01$ & $6.09 \mathrm{E}+01$ & $3.90 \mathrm{E}+00$ & $2.81 E+01$ \\
\hline $\mathrm{Cm}-243$ & - & $1.45 \mathrm{E}-02$ & - & $1.48 \mathrm{E}+02$ \\
\hline Cs-134 & - & $5.38 \mathrm{E}+01$ & $2.42 \mathrm{E}-02$ & $9.57 \mathrm{E}+00$ \\
\hline U-233 & $4.15 \mathrm{E}-01$ & $3.91 \mathrm{E}-01$ & $=$ & $5.73 E+01$ \\
\hline $\mathrm{Pm}-147$ & - & $1.49 \mathrm{E}+01$ & $1.13 \mathrm{E}+01$ & - \\
\hline Rh-106 & $\cdots$ & $6.65 \mathrm{E}-02$ & $3.38 \mathrm{E}-01$ & $3.21 E+01$ \\
\hline Ru-106 & - & $6.65 \mathrm{E}-02$ & $3.38 \mathrm{E}-01$ & $3.21 \mathrm{E}+01$ \\
\hline $\mathrm{Pr}-144$ & - & $3.93 \mathrm{E}+00$ & $1.58 \mathrm{E}-02$ & $1.51 \mathrm{E}+01$ \\
\hline $\mathrm{Ce}-144$ & - & $3.98 \mathrm{E}+00$ & $1.60 \mathrm{E}-02$ & $1.20 \mathrm{E}+01$ \\
\hline C-14 & $=$ & $4.00 \mathrm{E}-02$ & 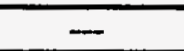 & $6.11 E+00$ \\
\hline $\mathrm{Kr}-85$ & - & $5.95 \mathrm{E}+00$ & - & - \\
\hline Sb-125 & - & $9.81 \mathrm{E}-01$ & $2.79 \mathrm{E}+00$ & $\ldots$ \\
\hline Cf-252 & - & - & - & $3.86 \mathrm{E}+00$ \\
\hline Ni-63 & $\ldots$ & $3.50 \mathrm{E}+00$ & - & - \\
\hline U-238 & $1.03 \mathrm{E}-02$ & $3.57 \mathrm{E}-03$ & $2.00 \mathrm{E}-05$ & $3.37 \mathrm{E}+00$ \\
\hline $\mathrm{Pa}-234 \mathrm{~m}$ & $1.03 \mathrm{E}=02$ & $1.38 \mathrm{E}-03$ & $2.00 \mathrm{E}-05$ & $3.37 \mathrm{E}+00$ \\
\hline Th-234 & $1.03 \mathrm{E}-02$ & $1.38 \mathrm{E}-03^{\circ}$ & $2.00 \mathrm{E}-05$ & $3.37 \mathrm{E}+00$ \\
\hline $\mathrm{U}-232$ & - & - & - & $1.76 \mathrm{E}+00$ \\
\hline Po-216 & $1.49 \mathrm{E}-03$ & $2.65 \mathrm{E}-05$ & $=$ & $1.68 \mathrm{E}+00$ \\
\hline Bi-212 & $1.49 \mathrm{E}-03$ & $2.65 E-05$ & - & $1.68 \mathrm{E}+00$ \\
\hline $\mathrm{Pb}-212$ & $1.49 \mathrm{E}-03$ & $2.65 \mathrm{E}-05$ & - & $1.68 \mathrm{E}+00$ \\
\hline $\mathrm{Ra}-224$ & $1.49 \mathrm{E}-03$ & $2.65 E-05$ & - & $1.68 \mathrm{E}+00$ \\
\hline $\mathrm{Rn}-220$ & $1.49 \mathrm{E}-03$ & $2.65 \mathrm{E}-05$ & - & $1.68 \mathrm{E}+00$ \\
\hline Th-228 & $1.49 \mathrm{E}-03$ & $2.65 \mathrm{E}-05$ & - & $1.68 E+00$ \\
\hline $\mathrm{U}-234$ & $1.29 \mathrm{E}+00$ & $1.51 \mathrm{E}-01$ & $1.11 \mathrm{E}-05$ & $2.02 \mathrm{E}-03$ \\
\hline Po-212 & $9.54 \mathrm{E}-04$ & $1.70 E-05$ & - & $1.07 \mathrm{E}+00$ \\
\hline $\mathrm{Te}-125 \mathrm{~m}$ & - & $2.39 \mathrm{E}-01$ & $6.88 \mathrm{E}-01$ & - \\
\hline
\end{tabular}


Table A.3. Decayed Radionuclide Inventories (Ci) Adjusted for Decay Through 2133 for CH TRU Waste by Generator/Storage Site for No Action Alternative 2

\begin{tabular}{|c|c|c|c|c|c|c|c|}
\hline Isotope & Hanford & INEL & LANL & LLNL & ORNL & RFETS & SRS \\
\hline Pu-238 & $1.71 E+05$ & $3.26 \mathrm{E}+04$ & $9.88 \mathrm{E}+04$ & $1.80 \mathrm{E}+02$ & $2.94 E+03$ & $5.17 \mathrm{E}+03$ & $4.99 E+05$ \\
\hline Pu-239 & $1.23 E+05$ & $4.25 E+04$ & $1.51 E+05$ & $8.50 \mathrm{E}+02$ & $3.90 \mathrm{E}+03$ & $2.67 \mathrm{E}+05$ & $1.87 E+04$ \\
\hline Am-241 & $2.41 \mathrm{E}+04$ & 8.27E+04 & $1.90 \mathrm{E}+04$ & $8.81 E+02$ & $3.82 \mathrm{E}+03$ & $2.25 \mathrm{E}+05$ & $9.93 E+03$ \\
\hline Pu-240 & $2.85 \mathrm{E}+04$ & $1.01 \mathrm{E}+04$ & $1.98 \mathrm{E}+02$ & $3.31 \mathrm{E}+02$ & $1.27 \mathrm{E}+03$ & $1.07 \mathrm{E}+05$ & $4.57 \mathrm{E}+03$ \\
\hline Pu-241 & $1.52 \mathrm{E}+03$ & $1.27 \mathrm{E}+03$ & $2.58 \mathrm{E}+01$ & $6.87 \mathrm{E}+01$ & $5.06 \mathrm{E}+02$ & $1.23 \mathrm{E}+04$ & $1.82 \mathrm{E}+03$ \\
\hline $\mathrm{Pu}-242$ & $1.78 \mathrm{E}+00$ & $7.91 \mathrm{E}+00$ & $9.23 E+02$ & $1.05 \mathrm{E}-01$ & $1.46 \mathrm{E}+00$ & $9.11 \mathrm{E}-04$ & $7.50 \mathrm{E}-01$ \\
\hline U-233 & $3.74 \mathrm{E}+02$ & $9.16 \mathrm{E}+02$ & $8.52 \mathrm{E}+01$ & $1.10 \mathrm{E}-06$ & $2.29 E+02$ & $1.23 \mathrm{E}+02$ & $7.50 \mathrm{E}+00$ \\
\hline U-234 & $3.26 \mathrm{E}+02$ & $2.18 \mathrm{E}+01$ & $5.43 E+01$ & $9.48 \mathrm{E}-02$ & $2.16 \mathrm{E}+01$ & $2.28 \mathrm{E}+00$ & $2.67 E+02$ \\
\hline Cs-137 & $3.20 \mathrm{E}+02$ & $1.05 \mathrm{E}+01$ & $9.23 E+\infty$ & 8.63E-07 & $2.86 \mathrm{E}-01$ & $0.00 E+00$ & $1.50 \mathrm{E}+00$ \\
\hline$Y-90$ & $2.97 \mathrm{E}+02$ & $3.09 \mathrm{E}+00$ & $7.81 E+\infty 0$ & $0.00 \mathrm{E}+\infty 0$ & $1.74 \mathrm{E}+02$ & $0.00 E+00$ & $1.28 \mathrm{E}+00$ \\
\hline ST-90 & $2.97 \mathrm{E}+02$ & $3.09 E+\infty 0$ & $7.81 \mathrm{E}+\infty$ & $0.00 \mathrm{E}+\infty 0$ & $1.74 \mathrm{E}+02$ & $0.00 \mathrm{E}+00$ & $1.28 \mathrm{E}+\infty$ \\
\hline $\mathrm{Cm}-245$ & $7.80 \mathrm{E}+01$ & $.2 .38 \mathrm{E}-01$ & $3.96 \mathrm{E}-03$ & $0.00 \mathrm{E}+00$ & $3.96 \mathrm{E}-02$ & $0.00 \mathrm{E}+00$ & $0.00 E+\infty$ \\
\hline $\mathrm{Cm}-244$ & $6.95 \mathrm{E}+\infty 0$ & $1.17 \mathrm{E}+01$ & $6.47 E+\infty 0$ & $7.36 E+\infty 0$ & $2.97 \mathrm{E}+01$ & $0.00 \mathrm{E}+00$ & $5.06 \mathrm{E}+01$ \\
\hline Th-234 & $2.74 \mathrm{E}+01$ & $2.03 E-01$ & 4.64E-02 & 1.57E- 01 & $6.89 \mathrm{E}-02$ & $0.00 \mathrm{E}+00$ & $1.14 \mathrm{E}-02$ \\
\hline U-238 & $2.74 \mathrm{E}+01$ & $2.03 \mathrm{E}-01$ & 4.64E-02 & $1.57 \mathrm{E}-01$ & $6.89 \mathrm{E}-02$ & $0.00 \mathrm{E}+00$ & $1.14 \mathrm{E}-02$ \\
\hline Tc-99 & 4.45E-05 & 2.57E-01 & 2.37E-02 & $0.00 \mathrm{E}+00$ & $2.28 \mathrm{E}+01$ & $0.00 \mathrm{E}+00$ & $8.99 \mathrm{E}-06$ \\
\hline $\mathrm{Pa}-233$ & $1.27 \mathrm{E}+\infty$ & $1.79 E+00$ & $7.69 \mathrm{E}-02$ & $2.44 \mathrm{E}-03$ & $1.15 \mathrm{E}+\infty 0$ & $1.61 \mathrm{E}-01$ & $1.72 \mathrm{E}+01$ \\
\hline Np-237 & $1.27 \mathrm{E}+\infty$ & $1.79 \mathrm{E}+00$ & 7.69E-02 & $2.44 \mathrm{E}-03$ & $1.15 \mathrm{E}+\infty$ & $1.61 \mathrm{E}-01$ & $1.72 \mathrm{E}+01$ \\
\hline Np-239 & 4.18E-01 & $6.31 \mathrm{E}-01$ & $7.21 E+00$ & $1.26 \mathrm{E}-01$ & $1.48 \mathrm{E}+01$ & $0.00 \mathrm{E}+\infty 0$ & $1.50 \mathrm{E}+00$ \\
\hline Am-243 & $4.18 \mathrm{E}-01$ & 6.31E-01 & $7.21 E+\infty$ & $1.26 \mathrm{E}-01$ & $1.48 \mathrm{E}+01$ & $0.00 \mathrm{E}+00$ & $1.50 \mathrm{E}+00$ \\
\hline Th-229 & $4.12 E+\infty$ & $1.02 \mathrm{E}+01$ & 9.53E- 01 & 5.31E-09 & $2.42 E+\infty 0$ & $1.16 E+00$ & $7.06 \mathrm{E}-02$ \\
\hline $\mathrm{Ra}-225$ & 4.12E $+\infty 0$ & $1.01 E+01$ & $9.53 \mathrm{E}-01$ & 5.31E-09 & $2.42 E+\infty 0$ & $1.16 \mathrm{E}+\infty$ & $7.05 \mathrm{E}-02$ \\
\hline Ac-225 & 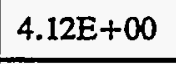 & $1.01 E+01$ & $9.53 \mathrm{E}-01$ & 5.30E-09 & $2.42 \mathrm{E}+00$ & $1.16 \mathrm{E}+00$ & $7.05 \mathrm{E}-02$ \\
\hline $\mathrm{Pb}-212$ & $4.55 \mathrm{E}-17$ & $1.01 \mathrm{E}+01$ & $3.65 \mathrm{E}-03^{\circ}$ & $0.00 \mathrm{E}+00$ & $1.70 \mathrm{E}-01$ & $0.00 \mathrm{E}+00$ & $7.02 \mathrm{E}-02$ \\
\hline Ra-224 & 4.55E-17 & $1.01 E+01$ & $3.65 \mathrm{E}-03$ & $0.00 E+\infty 0$ & $1.70 \mathrm{E}-01$ & $0.00 \mathrm{E}+\infty 0$ & $7.02 \mathrm{E}-02$ \\
\hline Th-228 & 4.53E-17 & $1.01 E+01$ & $3.65 \mathrm{E}-03$ & $0.00 E+00$ & $1.70 \mathrm{E}-01$ & $0.00 \mathrm{E}+\infty$ & $7.02 \mathrm{E}-02$ \\
\hline U-232 & $0.00 \mathrm{E}+00$ & $9.81 E+\infty$ & $3.55 \mathrm{E}-03$ & $0.00 \mathrm{E}+\infty$ & $1.65 \mathrm{E}-01$ & $0.00 \mathrm{E}+00$ & $6.84 \mathrm{E}-02$ \\
\hline
\end{tabular}


Täble A.3. (Contd)

\begin{tabular}{|l|l|l|l|l|l|l|l|}
\hline \multicolumn{1}{|c|}{ Isotope } & \multicolumn{1}{c|}{ Hanford } & \multicolumn{1}{c|}{ INEL } & \multicolumn{1}{c|}{ LANL } & \multicolumn{1}{c|}{ LLNL } & \multicolumn{1}{c|}{ ORNL } & \multicolumn{1}{c|}{ RFETS } & \multicolumn{1}{c|}{ SRS } \\
\hline Ra-226 & $5.56 \mathrm{E}-03$ & $1.53 \mathrm{E}-01$ & $1.65 \mathrm{E}+00$ & $1.13 \mathrm{E}-06$ & $8.03 \mathrm{E}+00$ & $1.81 \mathrm{E}-05$ & $2.66 \mathrm{E}-03$ \\
\hline Rn-222 & $1.42 \mathrm{E}-04$ & $1.52 \mathrm{E}-01$ & $1.65 \mathrm{E}+00$ & $1.99 \mathrm{E}-07$ & $8.03 \mathrm{E}+00$ & $0.00 \mathrm{E}+00$ & $1.40 \mathrm{E}-05$ \\
\hline $\mathrm{U}-235$ & $8.00 \mathrm{E}+00$ & $9.51 \mathrm{E}-02$ & $1.00 \mathrm{E}+00$ & $3.08 \mathrm{E}-03$ & $2.26 \mathrm{E}-02$ & $4.52 \mathrm{E}-04$ & $1.17 \mathrm{E}-02$ \\
\hline Th-231 & $8.00 \mathrm{E}+00$ & $9.51 \mathrm{E}-02$ & $1.00 \mathrm{E}+00$ & $3.08 \mathrm{E}-03$ & $2.26 \mathrm{E}-02$ & $4.52 \mathrm{E}-04$ & $1.17 \mathrm{E}-02$ \\
\hline Pb-210 & $1.38 \mathrm{E}-04$ & $1.50 \mathrm{E}-01$ & $1.62 \mathrm{E}+00$ & $1.92 \mathrm{E}-07$ & $7.84 \mathrm{E}+00$ & $0.00 \mathrm{E}+00$ & $1.36 \mathrm{E}-05$ \\
\hline Bi-210 & $1.38 \mathrm{E}-04$ & $1.50 \mathrm{E}-01$ & $1.62 \mathrm{E}+00$ & $1.92 \mathrm{E}-07$ & $7.84 \mathrm{E}+00$ & $0.00 \mathrm{E}+00$ & $1.36 \mathrm{E}-05$ \\
\hline Po-210 & $1.38 \mathrm{E}-04$ & $1.49 \mathrm{E}-01$ & $1.62 \mathrm{E}+00$ & $1.92 \mathrm{E}-07$ & $7.84 \mathrm{E}+00$ & $0.00 \mathrm{E}+00$ & $1.36 \mathrm{E}-05$ \\
\hline C-14 & $7.40 \mathrm{E}+00$ & $1.90 \mathrm{E}-01$ & $4.15 \mathrm{E}-04$ & $0.00 \mathrm{E}+00$ & $4.14 \mathrm{E}-03$ & $0.00 \mathrm{E}+00$ & $0.00 \mathrm{E}+00$ \\
\hline
\end{tabular}

Table A.4. Decayed Radionuclide Inventories (Ci) Adjusted for Decay Through 2133 for RH TRU Waste by Generator/Storage Site for No Action Alternative 2

\begin{tabular}{|l|c|c|c|c|}
\hline \multicolumn{1}{|c|}{ Isotope } & Hanford & $\cdot$ INEL & LANL & ORNL \\
\hline Cs-137 & $1.02 \mathrm{E}+05$ & $1.18 \mathrm{E}+03$ & $3.27 \mathrm{E}+01$ & $1.55 \mathrm{E}+03$ \\
\hline $\mathrm{Y}-90$ & $8.64 \mathrm{E}+04$ & $2.25 \mathrm{E}+03$ & $2.75 \mathrm{E}+01$ & $4.75 \mathrm{E}+03$ \\
\hline Sr-90 & $8.64 \mathrm{E}+04$ & $2.25 \mathrm{E}+03$ & $2.75 \mathrm{E}+01$ & $4.75 \mathrm{E}+03$ \\
\hline Pu-239 & $4.87 \mathrm{E}+04$ & $3.22 \mathrm{E}+02$ & $2.24 \mathrm{E}+02$ & $2.22 \mathrm{E}+02$ \\
\hline Am-241 & $4.37 \mathrm{E}+04$ & $3.29 \mathrm{E}+02$ & $0.00 \mathrm{E}+00$ & $3.54 \mathrm{E}+02$ \\
\hline Pu-240 & $2.40 \mathrm{E}+04$ & $1.26 \mathrm{E}+02$ & $0.00 \mathrm{E}+00$ & $3.89 \mathrm{E}+01$ \\
\hline Pu-241 & $5.52 \mathrm{E}+03$ & $2.05 \mathrm{E}+01$ & $0.00 \mathrm{E}+00$ & $6.82 \mathrm{E}+00$ \\
\hline Pu-238 & $3.08 \mathrm{E}+03$ & $6.80 \mathrm{E}+01$ & $4.28 \mathrm{E}+00$ & $2.96 \mathrm{E}+01$ \\
\hline Th-231 & $2.13 \mathrm{E}+01$ & $9.74 \mathrm{E}+01$ & $2.13 \mathrm{E}-02$ & $2.65 \mathrm{E}+02$ \\
\hline $\mathrm{U}-235$ & $2.13 \mathrm{E}+01$ & $9.74 \mathrm{E}+01$ & $2.13 \mathrm{E}-02$ & $2.65 \mathrm{E}+02$ \\
\hline $\mathrm{U}-234$ & $1.89 \mathrm{E}+02$ & $9.38 \mathrm{E}-01$ & $1.88 \mathrm{E}-03$ & $2.74 \mathrm{E}-01$ \\
\hline $\mathrm{U}-233$ & $6.04 \mathrm{E}+01$ & $3.08 \mathrm{E}+01$ & $0.00 \mathrm{E}+00$ & $8.17 \mathrm{E}+01$ \\
\hline $\mathrm{Cm}-244$ & $0.00 \mathrm{E}+00$ & $1.26 \mathrm{E}+01$ & $0.00 \mathrm{E}+00$ & $2.97 \mathrm{E}+01$ \\
\hline $\mathrm{Eu}-152$ & $0.00 \mathrm{E}+00$ & $1.06 \mathrm{E}+01$ & $6.80 \mathrm{E}-06$ & $2.88 \mathrm{E}+01$ \\
\hline $\mathrm{Cm}-243$ & $0.00 \mathrm{E}+00$ & $6.81 \mathrm{E}+00$ & $0.00 \mathrm{E}+00$ & $1.85 \mathrm{E}+01$ \\
\hline $\mathrm{C}-14$ & $0.00 \mathrm{E}+00$ & $3.22 \mathrm{E}+00$ & $0.00 \mathrm{E}+00$ & $8.61 \mathrm{E}+00$ \\
\hline $\mathrm{U}-238$ & $1.49 \mathrm{E}+00$ & $1.78 \mathrm{E}+00$ & $4.84 \mathrm{E}-05$ & $4.80 \mathrm{E}+00$ \\
\hline Th-234 & $1.49 \mathrm{E}+00$ & $1.78 \mathrm{E}+00$ & $4.84 \mathrm{E}-05$ & $4.80 \mathrm{E}+00$ \\
\hline $\mathrm{Ni}-63$ & $0.00 \mathrm{E}+00$ & $2.60 \mathrm{E}+00$ & $0.00 \mathrm{E}+00$ & $3.03 \mathrm{E}-01$ \\
\hline
\end{tabular}


Table A.5. Average Concentrations (ppmv) of Volatile Organic Compounds as Reported from the RCRA Part B Permit Application

\begin{tabular}{|c|c|c|c|c|c|}
\hline Final TRU Waste Form & $\begin{array}{c}\text { Carbon } \\
\text { Tetrachloride }\end{array}$ & Chlorobenzene & Chloroform & $\begin{array}{c}\text { Mehyl Ethyl } \\
\text { Ketone }\end{array}$ & $\begin{array}{l}\text { Methylene } \\
\text { Chloride }\end{array}$ \\
\hline Combustible & 566.52 & 1.54 & 41.09 & 7.60 & 12.29 \\
\hline Filter & 1.44 & 0.18 & 0.19 & 5.11 & 0.48 \\
\hline Graphite & 0.10 & 0.03 & 0.06 & 8.09 & 0.91 \\
\hline Heterogeneous & 91.07 & 9.46 & 18.99 & 62.05 & 143.13 \\
\hline Inorganic nonmetal & 3.27 & 0.16 & 1.03 & 7.29 & 2.56 \\
\hline Lead/cadium metal & 255.28 & 4.94 & 6.86 & 42.56 & 8.61 \\
\hline Salt & 4.32 & 0.18 & 0.23 & 5.50 & 0.56 \\
\hline Soils & 0 & 0 & 0 & .0 & 0 \\
\hline Solidified inorganics & 316.51 & 1.29 & 1.15 & 6.83 & 8.05 \\
\hline Solidified organics & $8,319.32$ & 94.30 & 135.98 & 717.96 & 214.47 \\
\hline Uncategorized metal & 9.58 & 13.40 & 7.94 & 39.34 & $1,941.71$ \\
\hline Final TRU Waste Form & $\begin{array}{c}1,1,2,2- \\
\text { Tetrachloroethane }\end{array}$ & Toluene & $\begin{array}{c}1,1- \\
\text { Dichloroethene }\end{array}$ & $\begin{array}{c}1,2- \\
\text { Dichloroethaine }\end{array}$ & $\begin{array}{c}1,1,1- \\
\text { Trichloroethane }\end{array}$ \\
\hline Combustible & 96.25 & 1.75 & 1.98 & 1.57 & 7.38 \\
\hline Filter & 16.08 & 0.14 & 0.32 & 0.26 & 11.63 \\
\hline Graphite & 8.06 & 0.03 & 0.04 & 0.03 & 0.63 \\
\hline Heterogeneous & 711.98 & 7.64 & 14.42 & 7.62 & 24.11 \\
\hline Inorganic nonmetal & 29.33 & 0.17 & 1.01 & 0.16 & 4.31 \\
\hline Lead/Cadmium metal & 510.47 & 4.89 & 11.62 & 5.23 & 8.97 \\
\hline Salt & 4.86 & 0.04 & 0.17 & 0.04 & 5.04 \\
\hline Soils & 0 & 0 & 0 & 0 & 0 \\
\hline Solidified inorganics & 125.09 & 1.26 & 2.45 & 1.06 & 6.26 \\
\hline Solidified organics & $4,543.96$ & 81.87 & 88.25 & 81.40 & 203.59 \\
\hline Uncategorized metal & 126.88 & 7.06 & 7.52 & 7.02 & 29.03 \\
\hline
\end{tabular}


Table A.6. Volume-Weighted Average Concentrations (ppmv) of Volatile Organic Compounds in $\mathrm{CH}$ TRU Waste for No Action Alternative 2

\begin{tabular}{|l|c|c|c|c|c|c|c|c|c|c|}
\hline $\begin{array}{l}\text { Volatile Organic } \\
\text { Compound }\end{array}$ & Hanford & LANL & INEL & SRS & RFETS & ORNL & LLNL & NTS & Mound & ANL-E \\
\hline $\begin{array}{l}\text { Carbon } \\
\text { tetrachloride }\end{array}$ & 60.20 & 271.20 & 372.68 & 122.89 & 274.93 & 90.19 & 152.06 & 93.09 & 22.44 & 28.93 \\
\hline Chlorobenzene & 9.65 & 6.20 & 9.41 & 8.33 & 2.67 & 9.37 & 9.45 & 9.39 & 3.75 & 12.16 \\
\hline Chloroform & 11.84 & 13.65 & 17.73 & 16.13 & 8.98 & 18.81 & 18.53 & 18.83 & 3.20 & 7.35 \\
\hline Methyl ethyl ketone & 40.40 & 21.00 & 54.23 & 53.43 & 19.57 & 61.45 & 62.88 & 61.55 & 11.22 & 36.64 \\
\hline Methylene chloride & 964.63 & 753.36 & 480.29 & 157.99 & 91.73 & 141.75 & 133.50 & 141.92 & 532.07 & $1,734.17$ \\
\hline $\begin{array}{l}1,1,2,2- \\
\text { Tetrachloroethane }\end{array}$ & 309.63 & 128.16 & 452.87 & 613.68 & 141.52 & 705.13 & 692.38 & 706.71 & 41.00 & 128.39 \\
\hline Toluene & 6.05 & 3.78 & 7.04 & 6.69 & 2.23 & 7.57 & 7.68 & 7.59 & 2.02 & 6.49 \\
\hline 1.1-Dichloroethene & 8.60 & 4.47 & 10.16 & 12.51 & 3.21 & 14.28 & 13.99 & 14.31 & 2.18 & 7.03 \\
\hline 1,2-Dichloroethane & 6.01 & 3.64 & 6.96 & 6.64 & 2.18 & 7.55 & 7.66 & 7.56 & 2.00 & 6.45 \\
\hline $\begin{array}{l}\text { 1,1,1- } \\
\text { Trichloroethane }\end{array}$ & 22.31 & 15.67 & 23.18 & 21.56 & 10.12 & 23.88 & 24.44 & 23.95 & 8.32 & 26.42 \\
\hline
\end{tabular}

Table A.7. Volume-Weighted Average Concentrations (ppmv) of Volatile Organic Compounds in RH TRU Waste for No Action Alternative 2

\begin{tabular}{|l|r|r|r|r|}
\hline \multicolumn{1}{|c|}{$\begin{array}{c}\text { Volatile Organic } \\
\text { Compound }\end{array}$} & Hanford & LANL & INEL & ORNL \\
\hline Carbon tetrachloride & 26.13 & 212.58 & 119.03 & 172.05 \\
\hline Chlorobenzene & 12.61 & 8.97 & 8.80 & 6.53 \\
\hline Chloroform & 10.08 & 20.34 & 17.44 & 12.58 \\
\hline Methyl ethyl ketone & 43.76 & 29.16 & 56.88 & 42.19 \\
\hline Methylene chloride & $1,586.14$ & $1,161.64$ & 172.75 & 94.56 \\
\hline 1,1,2,2- & 241.67 & 145.58 & 638.56 & 500.94 \\
Tetrachloroethane & & & & \\
\hline Toluene & 7.17 & 5.20 & 7.05 & 5.35 \\
\hline 1.1-Dichloroethene & 8.87 & 5.89 & 13.07 & 10.12 \\
\hline 1,2-Dichloroethane & 7.13 & 5.11 & 7.02 & 5.26 \\
\hline 1,1,1-Trichloroethane & 28.01 & 21.05 & 22.56 & 17.69 \\
\hline
\end{tabular}


Table A.8. Inventory (g) of Volatile Organic Compounds in CH TRU Waste for the No Action Alternative 2

\begin{tabular}{|l|r|r|r|r|r|r|r|}
\hline \multicolumn{1}{|c|}{ Compound } & \multicolumn{1}{c|}{ Hanford } & \multicolumn{1}{c|}{ INEL } & \multicolumn{1}{c|}{ LANL } & \multicolumn{1}{c|}{ ORNL } & \multicolumn{1}{c|}{ RFETS } & \multicolumn{1}{c|}{ SRS } & \multicolumn{1}{c|}{ LLNL } \\
\hline Carbon tetrachloride & 139,660 & 438,499 & 230,351 & 6,730 & 120,509 & 59,830 & 7,333 \\
\hline Chloroform & 20,560 & 15,608 & 8,674 & 1,050 & 2,946 & 5,878 & 669 \\
\hline 1.1-Dichloroethene & 3,759 & 2,253 & 715 & 201 & 265 & 1,147 & 127 \\
\hline Methylene chloride & 698,580 & 176,405 & 199,743 & 3,302 & 12,551 & 24,010 & 2,010 \\
\hline 1,1,2,2-Tetrachloroethane & $16,234,213$ & $12,042,561$ & $2,460,196$ & $1,189,188$ & $1,401,930$ & $6,752,290$ & 754,557 \\
\hline Chlorobenzene & 216,336 & 106,937 & 50,878 & 6,756 & 11,324 & 39,169 & 4,401 \\
\hline Methyl ethyl ketone & 136,670 & 93,043 & 26,013 & 6,686 & 12,509 & 37,925 & 4,421 \\
\hline Toluene & 56,419 & 33,311 & 12,894 & 2,272 & 3,939 & 13,090 & 1,489 \\
\hline 1,2-Dichloroethane & 24,633 & 14,463 & 5,461 & 994 & 1,691 & 5,705 & 652 \\
\hline 1,1,1-Trichloroethane & 47,554 & 25,053 & 12,230 & 1,637 & 4,074 & 9,645 & 1,083 \\
\hline
\end{tabular}

Table A.9. Inventory (g) of Volatile Organic Compounds in RH TRU Waste for the No Action Alternative 2

\begin{tabular}{|l|r|r|r|r|}
\hline \multicolumn{1}{|c|}{ Compound } & Hanford & \multicolumn{1}{c|}{ INEL } & \multicolumn{1}{c|}{ LANL } & \multicolumn{1}{c|}{ ORNL } \\
\hline Carbon tetrachloride & 31,024 & 9,397 & 1,959 & 25,450 \\
\hline Chloroform & 8,958 & 1,031 & 140 & 1,392 \\
\hline 1.1-Dichloroethene & 1,983 & 194 & 10 & 282 \\
\hline Methylene chloride & 587,915 & 4,257 & 3,342 & 4,366 \\
\hline 1,1,2,2-Tetrachloroethane & $6,485,477$ & $1,139,327$ & 30,327 & $1,674,680$ \\
\hline Chlorobenzene & 144,586 & 6,712 & 798 & 9,323 \\
\hline Methyl ethyl ketone & 75,757 & 6,547 & 392 & 9,100 \\
\hline Toluene & 34,223 & 2,238 & 193 & $3,181$. \\
\hline 1,2-Dichloroethane & 14,949 & 978 & 83 & 1,374 \\
\hline 1,1,1-Trichloroethane & 30,552 & 1,636 & 178 & 2,405 \\
\hline
\end{tabular}


Table A.10. Concentration of Hazardous Metals

\begin{tabular}{|l|c|c|}
\hline \multicolumn{1}{|c|}{ Metal } & $\begin{array}{c}\text { CH TRU Waste Inventory } \\
\left(\mathbf{k g} / \mathbf{m}^{3}\right)\end{array}$ & $\begin{array}{c}\text { RH TRU Waste } \\
\text { Inventory }\left(\mathbf{k g} / \mathbf{m}^{3}\right)\end{array}$ \\
\hline Beryllim & $1.21 \mathrm{E}-01$ & $1.21 \mathrm{E}-01$ \\
\hline Cadmium & $1.73 \mathrm{E}-03$ & $1.74 \mathrm{E}-03$ \\
\hline Lead & $4.79 \mathrm{E}+00 . \cdot$ & $4.64 \mathrm{E}+02$ \\
\hline Mercury & $2.05 \mathrm{E}+00$ & $2.05 \mathrm{E}+00$ \\
\hline
\end{tabular}

Table A.11. Inventory (g) of Inorganic Metals in $\mathrm{CH}$ and RH TRU Waste for No Action Alternative 2

\begin{tabular}{|l|c|c|c|c|c|c|c|}
\hline \multicolumn{1}{|c|}{ Inventor } & Hanford & INEL & LANL & ORNL & RFETS & SRS & LLNL \\
\hline Total lead & $1.56 \mathrm{E}+10$ & $1.16 \mathrm{E}+09$ & $2.20 \mathrm{E}+08$ & $1.92 \mathrm{E}+09$ & $5.21 \mathrm{E}+07$ & $5.78 \mathrm{E}+07$ & $5.73 \mathrm{E}+06$ \\
\hline CHi lead & $2.76 \mathrm{E}+08$ & $1.40 \mathrm{E}+08$ & $1.01 \mathrm{E}+08$ & $8.86 \mathrm{E}+06$ & $5.21 \mathrm{E}+07$ & $5.78 \mathrm{E}+07$ & $5.73 \mathrm{E}+06$ \\
\hline RH lead & $1.54 \mathrm{E}+10$ & $1.02 \mathrm{E}+09$ & $1.19 \mathrm{E}+08$ & $1.92 \mathrm{E}+09$ & - & - & - \\
\hline Total cadmium & $1.51 \mathrm{E}+05$ & $5.41 \mathrm{E}+04$ & $3.70 \mathrm{E}+04$ & $9.59 \mathrm{E}+03$ & $1.89 \mathrm{E}+04$ & $2.10 \mathrm{E}+04$ & $2.08 \mathrm{E}+03$ \\
\hline CH cadmium & $9.99 \mathrm{E}+04$ & $5.07 \mathrm{E}+04$ & $3.66 \mathrm{E}+04$ & $3.21 \mathrm{E}+03$ & $1.89 \mathrm{E}+04$ & $2.10 \mathrm{E}+04$ & $2.08 \mathrm{E}+03$ \\
\hline RH cadmium & $5.12 \mathrm{E}+04$ & $3.40 \mathrm{E}+03$ & $3.97 \mathrm{E}+02$ & $6.37 \mathrm{E}+03$ & - & - & - \\
\hline Total beryllium & $1.05 \mathrm{E}+07$ & $3.77 \mathrm{E}+06$ & $2.58 \mathrm{E}+06$ & $6.68 \mathrm{E}+05$ & $1.32 \mathrm{E}+06$ & $1.46 \mathrm{E}+06$ & $1.45 \mathrm{E}+05$ \\
\hline CH beryllim & $6.97 \mathrm{E}+06$ & $3.53 \mathrm{E}+06$ & $2.55 \mathrm{E}+06$ & $2.24 \mathrm{E}+05$ & $1.32 \mathrm{E}+06$ & $1.46 \mathrm{E}+06$ & $1.45 \mathrm{E}+05$ \\
\hline RH beryllium & $3.57 \mathrm{E}+06$ & $2.37 \mathrm{E}+05$ & $2.77 \mathrm{E}+04$ & $4.44 \mathrm{E}+05$ & - & - & - \\
\hline Total mercury & $1.79 \mathrm{E}+08$ & $6.39 \mathrm{E}+07$ & $4.37 \mathrm{E}+07$ & $1.13 \mathrm{E}+07$ & $2.23 \mathrm{E}+07$ & $2.48 \mathrm{E}+07$ & $2.45 \mathrm{E}+06$ \\
\hline CH mercury & $1.18 \mathrm{E}+08$ & $5.99 \mathrm{E}+07$ & $4.32 \mathrm{E}+07$ & $3.80 \mathrm{E}+06$ & $2.23 \mathrm{E}+07$ & $2.48 \mathrm{E}+07$ & $2.45 \mathrm{E}+06$ \\
\hline RH total mercury & $6.05 \mathrm{E}+07$ & $4.02 \mathrm{E}+06$ & $4.69 \mathrm{E}+05$ & $7.53 \mathrm{E}+06$ & - & - & - \\
\hline
\end{tabular}


Appendix B

\section{Contaminant Property Data}




\section{Appendix B}

\section{Contaminant Property Data}

Various calculations made in the No Action Alternative 2 analyses require contaminant property

data as input variables. Degradation/decay coefficients and sorption $\mathrm{K}_{d}$ values are needed to determine flux factors and unit transport factors. Solubilities are needed to determine flux factors. Effective diffusion coefficients in cement are needed to determine flux factors for waste forms in the cemented waste-form category. This appendix describes the methods, including computer codes, used to obtain specific values for these parameters at the different sites and tabulates the values used in instances where these yalues were not "default" values reported in referenced literature.

\section{B.1 Contaminant Degradation/Decay Coefficients}

The Multimedia Environmental Pollutant Assessment System (MEPAS) chemical database (augmented from that reported in Strenge and Peterson [1989] by adding more contaminants and updating some parameter values) contains radioactive decay half-lives for radionuclides. These values were used to calculate decay-rate coefficients for radionuclides in the No-Action Alternative 2 analyses. Although organic chemicals can degrade by a variety of microbiological, chemical, and physical processes, effective first-order degradation-rate coefficients would be highly site specific, time varying, and dependent on a number of factors that would not generally be well known for sites under evaluation. Therefore, degradation is neglected for organic chemicals; and the degradation-rate coefficients are assumed to be zero. It is further assumed that degradation-rate coefficients for metals are also zero.

\section{B.2 Contaminant Solubilities}

Modeling of solubility bounded contaminant release from all waste forms depends on contaminant/ waste-form/site-specific solubility limits. The MEPAS chemical database (augmented from that reported in Strenge and Peterson [1989]) contains solubility values for organic chemicals but has little solubility information for radionuclide and inorganic chemicals. This is because solubility values for inorganic contaminants depend on many site-specific properties and it is difficult to supply a single meaningful point value for these contaminants. Developing site-specific solubilities for all contaminants in the site inventory would be a formidable, and ultimately unnecessary, task. Instead, a screening was done to determine which contaminants would be the primary contributors to risk at each site, initially ignoring solubility concerns. (See Section 6.3 in the main text for a description of the screening procedures and Table 6:2 for the resulting list of waterborne contaminants of concern.) If contaminants are present in low concentrations, have low toxicity values, decay rapidly, and/or have very low mobility, they could be eliminated from further consideration without generating a solubility

B.1 
limit. The screened list was further reduced by calculating the highest aqueous-phase concentration for each contaminant at each site, based on soil properties and contaminant $K_{d}$ values. If the highest possible water concentration was $<0.001 \mathrm{mg} / \mathrm{L}$, it was assumed that solubility would not be important enough to merit calculation. The analysis focused on radioactive contaminants. However, lead was also included in the analysis because it was known to exist in large quantities due to its use as a shielding material.

The solubility calculations were completed for 6 of the 7 sites under condsideration. Calculations were not completed for the Lawerence Livermore National Laboratory because it was added to the list of sites at a later time and at that point, the solubility calculations had shown to have only minor effects on risk calculations. The solubilities were calculated for two possible waste forms: 'soil/debris and cement. Solubility limits for cemented waste forms stored at the Hanford Site were not calculated because the Hanford Site does not currently have any of this waste form. Solubility limits for cemented waste forms at the Savannah River Site were also not calculated because concerns about this waste form were established later in the analysis after the solubility calculations had shown to have only minor effects on the risk calculation. Waterborne contaminants of concern that had possible water concentrations $0.001 \mathrm{mg} / \mathrm{L}$ included lead, neptunium, plutonium, and uranium. This effort attempted to calculate conservative maximum concentration limits for each of these contaminants, based on equilibrium solubility considerations. The following section describes how the inorganic solubilities used in the analyses were calculated.

\section{B.2.1 Geochemical Speciation Code and Associated Thermodynamic Databases}

The site-specific inorganic solubilities were calculated using the chemical equilibria code MINTEQA2 (Version 3.11), which is based on equilibrium thermodynamic solubility principles. See Garrels and Christ (1965), Lindsay (1979), Morel (1983), Nordstrom and Munoz (1985), Stumm and Morgan (1981), and Allison et al. (1991) regarding the use of thermodynamic principles to calculate solubility equilibria in aqueous systems.

As part of a PNNL study, the database obtained with the MINTEQA2 code was expanded to include the aqueous species and solids containing the radionuclide elements americium, neptunium, plutonium, radium, technetium, thorium, and uranium. These database modifications and the sources of these data are described in detail in Krupka and Serne (1996): The database changes for the aqueous species and solids containing uranium are based on the compilation by Grenthe et al. (1992) and supersede those listed in the MINTEQA2 database as obtained from EPA.

\section{B.2.2 Geochemical Environments}

Prior to running the MINTEQ computer code, various assumptions must be made regarding specific geochemical conditions. The geochemical environments selected for modeling represent a best estimate, based on the resources available for the solubility-modeling calculations. Three geochemical 
environments were considered for the solubility calculations. Each environment conceptually corresponds to a leachate that results from the interaction of soil-pore water with each type of waste form (i.e., soil/debris and cemented) as a closed environment under equilibrium conditions. These conditions should result in conservative maximum concentration limits, in that the concentrations of contaminants will be decreased by dilution in open flow-through systems.

In the absence of site-specific waste-form leachate data, it was assumed that, except for $\mathrm{pH}$ and concentration of dissolved carbonate, the leachate composition would mimic that of the soil-pore water. Assumptions regarding the oxidation/reduction conditions were also required for modeling the geochemical environment. Site-specific pore-water compositions, oxidation/reduction conditions, and conceptual models used for determining the $\mathrm{pH}$ and concentration of dissolved carbonate for each waste form are discussed below.

The compositions selected to simulate soil-pore waters at each site are listed in Table B.1. These data were compiled from the following sources:

- Hanford Site - Serne et al. (1993)

- Idaho National Engineering Laboratory - Personal communication, January 1996, C. A. Dicke (Senior Scientist, Idaho National Engineering Laboratory, Lockheed Martin Idaho Technologies, Idaho Falls, Idaho)

Table B.1. Compositions of Soil-Pore Waters Used for Solubility Modeling

\begin{tabular}{|c|c|c|c|c|c|c|}
\hline & Hanford & INEL & LANL & ORNL & REETS & SRS \\
\hline$\overline{\mathrm{pH}}$ & 7.9 & 7.68 & 7.9 & 7.3 & See LANL & 4.9 \\
\hline \multicolumn{7}{|c|}{ Constituent, $\mathrm{mg} / \mathrm{L}$} \\
\hline $\mathrm{Na}$ & 35 & 258 & 14 & 3.3 & See LANL & 10 \\
\hline $\mathrm{K}$ & $\overline{6.8}$ & 3.6 & 2.1 & 3.1 & See LANL & $<0.1^{(a)}$ \\
\hline $\mathrm{Ca}$ & 58 & 65.6 & 18 & 39.2 & See LANL & 8.6 \\
\hline $\mathrm{Mg}$ & 15 & 32.6 & 4.4 & 4.5 & See LANL & $<0.1^{(2)}$ \\
\hline $\mathrm{H}_{4} \mathrm{SiO}_{4}$ & 63.6 & $\mathrm{NL}^{(0)}$ & 70.4 & 16.2 & See LANL & NL \\
\hline $\mathrm{HCO}_{3}$ & 34 & 695.6 & 77 & 142 & See LANL & $<0.05^{(2)}$ \\
\hline $\mathrm{SO}_{4}$ & 85 & 186.4 & 9 & 8 & See LANL & 30 \\
\hline $\mathrm{Cl}$ & 71 & 59.9 & 15 & 1.6 & See LANL & 4 \\
\hline $\bar{F}$ & 1 & NL & 1.7 & $\mathrm{NL}$ & See LANL & NL \\
\hline $\mathrm{NO}_{3}$ & NL & $\mathrm{NL}$ & NL & NL & See LANL & 8 \\
\hline $\mathrm{PO}_{4}$ & $\mathrm{NL}$ & $\mathrm{NL}$ & $\mathrm{NL}$ & $\mathrm{NL}$ & See LANL & $\mathrm{NL}$ \\
\hline \multicolumn{7}{|c|}{$\begin{array}{l}\text { (a) Limiting value used for solubility calculations. } \\
\text { (b) NL - None listed. }\end{array}$} \\
\hline
\end{tabular}


- Los Alamos National Laboratory - Environmental Protection Group (1994)

- Oak Ridge National Laboratory - Davis et al. (1984)

- Savannah River Site - Savannah River Laboratory (1985).

A source for soil-pore compositions could not be identified for the Rocky Flats Environmental Technology Site. Based on the approach used for other aspects of this risk analysis (e.g., $\mathbf{K}_{\mathrm{d}}$ sorption values), it was assumed that composition of soil-pore water for this site could be approximated by that used for the Los Alamos National Laboratory.

-Waste storage is assumed to be in surface or near-surface soil environments, where there is free exchange of oxygen and carbon dioxide gas between the atmosphere, soil, pore waters, and waste form. Because of kinetic considerations and formation of corrosion products; it was also assumed that the corrosion of any metal constituents (e.g., metallic iron) in the waste would have no impact on the oxidation state of the leachate. As a result of these two assumptions, the solubilities were calculated using only the most oxidized valence state of environmental consequence for each contaminant. In most cases, the solubilities of the reduced valence states of the contaminants of concern are expected to be less than those calculated for the oxidized forms.

\section{B.2.2.1 Soil/Debris-Waste Leachate Compositions}

The leachate from soil/debris waste was assumed to have the same composition as the site pore water listed in Table B.1. Because the waste is expected to contain a significant amount of site soil, the leachate composition is expected to be controlled by the same reactions that control the composition of the soil-pore water. The leachate $\mathrm{pH}$ is also assumed to be the same as that listed for the soil-pore water.

Because carbonate is a strong complexant of some dissolved contaminants, such as uranium, the concentrations of dissolved carbonate used for the soil/debris leachate were modeled in two ways. One set of calculations was based on the concentration of dissolved carbonate listed for the soil-pore waters in Table B.1. A second set of calculations assumed that the concentration of dissolved carbonate was fixed by assumed equilibrium with carbon dioxide gas. For this latter calculation, a partial pressure of $0.003 \mathrm{~atm}$ carbon dioxide (10 times that of atmospheric carbon dioxide) was used to constrain the concentration of dissolved carbonate. This pressure is often used as the reference for carbon dioxide in soil systems (Lindsay 1979). To provide the most conservative maximum concentration limits for soil/ debris waste, Table B.2 only lists the larger of the two contaminant-solubility concentrations calculated from these different conceptual models for dissolved carbonate.

\section{B.2.2.2 Cemented Waste Leachate Composition}

Except for $\mathrm{pH}$ and dissolved carbonate concentrations, the leachate from cemented waste was assumed to have the same composition as the site pore water listed in Table B.1. 
Table B.2. Calculated Solubilities Used for No Action Alternative 2 (all values are milligrams/liter)

\begin{tabular}{|c|c|c|c|c|c|c|c|c|c|c|c|c|c|c|}
\hline \multirow[b]{2}{*}{$\begin{array}{c}\text { Contam- } \\
\text { Inant }\end{array}$} & $\begin{array}{l}\text { Hanford } \\
200 \mathrm{E}\end{array}$ & $\begin{array}{c}\text { Hanford } \\
200 \mathrm{~W}\end{array}$ & \multicolumn{2}{|c|}{ INEL, } & \multicolumn{2}{|c|}{ LANL } & \multicolumn{2}{|c|}{ ORNL } & \multicolumn{2}{|c|}{ RFETS } & \multicolumn{2}{|c|}{ SRS } & \multicolumn{2}{|c|}{ LLNL } \\
\hline & \multicolumn{2}{|c|}{ Soll/Debris } & $\begin{array}{l}\text { Solll } \\
\text { Debris }\end{array}$ & Cement & $\begin{array}{c}\text { Soill } \\
\text { Debrls }\end{array}$ & Cement & $\begin{array}{c}\text { Solll } \\
\text { Debrls }\end{array}$ & Cement & $\begin{array}{l}\text { Solll } \\
\text { Debris }\end{array}$ & Cement & $\begin{array}{l}\text { Soll/ } \\
\text { Debris }\end{array}$ & Cement & $\begin{array}{c}\text { Solll } \\
\text { Debris }\end{array}$ & Cement \\
\hline$\overline{\mathrm{C}-14}$ & $<0.001^{(8)}$ & $<0.001$ & $<0.001$ & $<0.001$ & $<0.001$ & $<0.001$ & $<0.001$ & $<0.001$ & $<0.001$ & $<0.001$ & $<0.001$ & $<0.001$ & $<0.001$ & $<0.001$ \\
\hline $\mathrm{Cm} \cdot 243$ & $<0.001$ & $<0.001$ & $<0.001$ & $<0.001$ & $<0.001$ & $<0.001$ & $<0.001$ & $<0.001$ & $<0.001$ & $<0.001$ & $<0.001$ & $<0.001$ & $<0.001$ & $<0.001$ \\
\hline $\mathrm{Cm}-244$ & $<0.001$ & $<0.001$ & $<0.001$ & $<0.001$ & $<0.001$ & $<0.001$ & $<0.001$ & $<0.001$ & $<0.001$ & $<0.001$ & $<0.001$ & $<0.001$ & $<0.001$ & $<0.001$ \\
\hline Lead & $0.2^{(c)}$ & $0.2^{(c)}$ & $0.2^{(4)}$ & $40,000^{(4)}$ & $0.2^{(s)}$ & $40,000^{(0)}$ & $0.4^{(s)}$ & $40,000^{(1)}$ & $0.2^{(c)}$ & $40,000^{(4)}$ & $2,000^{(c)}$ & $N C^{(1)}$ & NC & NC \\
\hline Np-237 & $900^{(d)}$ & $900^{(4)}$ & $2,000^{(4)}$ & $10^{(6)}$ & $900^{(4)}$ & $50^{(0)}$ & $2,000^{(1)}$ & $50^{(3)}$ & $900^{(4)}$ & $50^{(0)}$ & $700,000^{(0)}$ & NC & $N C$ & NC \\
\hline Pu-238 & $70^{(4)}$ & $70^{(1)}$ & $500^{(d)}$ & $0.00005^{(\text {(c) }}$ & $50^{(1)}$ & $0.000005^{(c)}$ & $20^{(s)}$ & $0.000005^{(c)}$ & $50^{(d)}$ & $0.00001^{(0)}$ & $0.001^{(c)}$ & NC & NC & NC \\
\hline Pu-239 & $70^{(6)}$ & $70^{(1)}$ & $500^{(s)}$ & $0.00005^{(c)}$ & $50^{(1)}$ & $0.000005^{(t)}$ & $20^{(4)}$ & $0.000005^{(c)}$ & $50^{(4)}$ & $0.00001^{(s)}$ & $0.001^{(0)}$ & NC & NC & NC \\
\hline Pu-240 & $70^{(1)}$ & $70^{(4)}$ & $500^{(4)}$ & $0.00005^{(6)}$ & $50^{(4)}$ & $0.000005^{(t)}$ & $20^{(3)}$ & $0.000005^{(6)}$ & $50^{(0)}$ & $0.00001^{(0)}$ & $0.001^{(t)}$ & NC & NC & NC \\
\hline U-233 & $200^{\prime \prime \prime}$ & $200^{(1)}$ & $500^{(1)}$ & $0.001^{(c)}$ & $200^{(4)}$ & $0.9^{(4)}$ & $50^{(4)}$ & $5^{(4)}$ & $200^{(1)}$ & $0.9^{(d)}$ & $7^{(4)}$ & NC C & NC & NC \\
\hline$U-234$ & $200^{(1)}$ & $200^{(4)}$ & $500^{(6)}$ & $0.001^{(c)}$ & $200^{(4)}$ & $0.9^{(0)}$ & $50^{(4)}$ & $5^{(4)}$ & $200^{(4)}$ & $0.9^{(0)}$ & $7(1)$ & NC & NC & NC \\
\hline U-235 & $200^{(1)}$ & $200^{(0)}$ & $500^{(3)}$ & $0.001^{(5)}$ & $200^{(4)}$ & $0.9^{(d)}$ & $50^{(4)}$ & $5^{(1)}$ & $200^{(6)}$ & $0.9^{(4)}$ & $7^{(0)}$ & NC & NC & NC \\
\hline $\begin{array}{l}\text { (a) NC- } \\
\text { (b) }<0 . \text {. } \\
\text { (c) Calcu } \\
\text { (d) Calcu }\end{array}$ & $\begin{array}{l}\text { alculated } \\
\text { Maxim! } \\
\text { solubili } \\
\text { I solubili }\end{array}$ & $\begin{array}{l}\text { ucous } \\
\text { tally } \\
t \text { solut }\end{array}$ & $\begin{array}{l}\text { ntration } \\
\text { ty limit } \\
\text { imited. }\end{array}$ & mas & & & & & . & & & . & & \\
\hline
\end{tabular}


The $\mathrm{pH}$ of the cement leachate was assumed to be 12.5 as a result of buffering by the solubility of portlandite, $\mathrm{Ca}(\mathrm{OH})_{2}$, in cement. In the absence of detailed reactive transport computer simulations of how the cement leachate $\mathrm{pH}$ changes as a function of time from dissolution of cemented waste forms at site-specific environmental factors (e.g., water-recharge rates), this $\mathrm{pH}$ value was considered a conservative, limiting $\mathrm{pH}$ value for cement leachate. The chemical reactions associated with the hydration of cement are described in detail in International Atomic Energy Agency (1993), Atkins and Glasser (1992), and Reardon (1992).

The concentrations of dissolved carbonate were fixed by assuming equilibrium with the solubility of calcite, $\mathrm{CaCO}_{3}$. Calcite is known to precipitate as a result of carbonation reactions occurring with the dissolution of cement (Criscenti and Serne 1990; Duerden et al. 1990; Reardon and Dewaele 1990; Smith and Walton 1991).

\section{B.2.3 Solid-Phase Solubility Controls}

Conservative maximum concentration limits for dissolved lead, neptunium, plutonium, and uranium were calculated using the MINTEQA2 code. The concentration limits are based on solubility controls selected for each of the dissolved contaminants, based on the contaminant-containing solid phases in the MINTEQA2 thermodynamic database.

Selection of the most appropriate solubility control(s) was based on phase-stability information given in published studies and the experience that project staff have with the geochemistry of radionuclide aqueous systems. The selected solubility controls are the following:

- lead - cerussite $\left(\mathrm{PbCO}_{3}\right)$ for leachates from all waste types

- neptunium - $\mathrm{NpO}_{2}(\mathrm{OH})(\mathrm{am})$ for leachates from all waste types

- plutonium $-\mathrm{PuO}_{2} \cdot \mathrm{H}_{2} \mathrm{O}(\mathrm{am})$ for leachates from all waste types

- uranium - schoepite $\left[\mathrm{UO}_{2}(\mathrm{OH})_{2} \cdot \mathrm{H}_{2} \mathrm{O}\right]$ for leachates from soil/debris and uranophane $\left[\mathrm{Ca}\left(\mathrm{H}_{3} \mathrm{O}\right)_{2}\left(\mathrm{UO}_{2}\right)_{2}\left(\mathrm{SiO}_{4}\right)_{2} \cdot 3 \mathrm{H}_{2} \mathrm{O}\right]$ for cement leachate.

Except for lead, the rationale for selecting the solubility controls used for the other contaminants listed above is discussed by Krupka and Serne (1996). They used geochemical modeling to simulate radionuclide solubilities over the $\mathrm{pH}$ range from 4.0 to 12.5 in support of a performance assessment of a hypothetical low-level waste-disposal facility. Cerussite was selected for the solubility control of lead, based on analyses by Lindsay (1979) of chemical equilibria in soil/water systems. The solubilities based on the amorphous solids are expected to be highly conservative maximum concentration limits. These solids are known to precipitate at laboratory time scales but will crystallize over time to solids that are more thermodynamically stable and have 
lower solubilities. The kinetic rates for completing these crystallization processes are not known for radionuclide solids in soil/water environments.

For other contaminants, such as uranium, modeling and/or laboratory evidence suggests that the solubilities of different solid phases may be controlling the concentrations of their constituent metals over different pH regions. For example, two solubility controls, schoepite and uranophane, were considered in calculating maximum concentration limits of dissolved uranium. Schoepite is known to precipitate readily in low-temperature aqueous systems at laboratory time scales and result in high concentrations of dissolved uranium (Krupka et al. 1985). In natural low-temperature aqueous systems, the presence of alkali and/or alkaline earth ions at high $\mathrm{pH}$ conditions would result in the precipitation of alkali/alkaline earth uranium compounds that would control the solubility of uranium to concentrations lower than those resulting from equilibrium with schoepite. Concentration limits, based on schoepite, are, therefore, suspected to be highly conservative. Atkins et al. $(1990,1991)$ investigated uranium reactions with portlandite and hydrated calcium silicate hydrogel solutions. Three uranium-containing phases, which included uranophane, a hydrated calcium uranyl oxide $\left[\mathrm{Ca}_{2} \mathrm{UO}_{5} \cdot(1.2-1.5) \mathrm{H}_{2} \mathrm{O}\right]$, and becquerelite $\left(\mathrm{CaU}_{6} \mathrm{O}_{19} \cdot \mathrm{H}_{2} \mathrm{O}\right)$ were identified by $\mathrm{X}$-ray diffraction and analytical electron microscopy in the resulting mixtures. The solubilities of these phases will, therefore, represent more realistic concentration limits for dissolved uranium in cementitious systems than those based on the solubility of schoepite. However, the solubilities of the hydrated calcium uranyl oxide phase and becquerelite cannot be calculated because the required thermodynamic data for these phases are not available.

\section{B.2.4 Estimated Contaminant Solubilities}

During the screening analysis (see Section 6.3 of the main text), expected aqueous concentrations (in the absence of solubility limitations) of each contaminant of concern were calculated, based on inventory, $\mathrm{K}_{\mathrm{d}}$, and volume of pore water in the waste zone. If the maximum concentration was below $0.001 \mathrm{mg} / \mathrm{L}$, it was assumed that solubility would not be a controlling factor in determining the contaminant's aqueous concentration. Table B. 2 shows if solubility is an important issue for each contaminant/waste form/site combination. Table B.2 also reports the calculated solubility values for the remaining combinations where solubility limitations may be an issue. These calculated solubility values were compared to the maximum aqueous concentrations determined in the screening analysis to determine which contaminant/waste form/site combinations would be solubility limited. Table B. 2 showed that plutonium, uranium, and lead are the only contaminants that have releases that are controlled by solubility at one or more sites.

A few of the reported solubilities did not affect the analysis but required further comment regarding their accuracy. The maximum concentration limit of $700,000 \mathrm{mg} / \mathrm{L}$, calculated for neptunium in $\mathrm{pH} 4.9$ leachate from soil/debris waste at the Savannah River Site, is considered unrealistic. It is suspected that the adequacy of the thermodynamic data for neptunium, especially solubility-controlling phases, may be a contributing factor in the high concentrations predicted for 
the solubility of neptunium. However, the maximum water concentration calculated for neptunium237 at the Savannah River Site, based on contaminant $K_{d}$ and soil properties, is $0.23 \mathrm{mg} / \mathrm{L}$.

Therefore, it is likely that a more realistic solubility value would still exceed the $0.23-\mathrm{mg} / \mathrm{L}$ value, and that the release of neptunium-237 is not controlled by solubility.

The maximum concentration limit calculated for lead in cemented waste leachates at $\mathrm{pH} 12.5$ is $40,000 \mathrm{mg} / \mathrm{L}$. This value is also considered to be unrealistically high. The unrealistic solubility value calculated for lead probably results from inadequate thermodynamic data for the lead hydrolysis species that are predicted to be present at the high $\mathrm{pH}$ value for cemented leachate. The maximum lead leachate concentrations from the Oak Ridge National Laboratory and Los Alamos National Laboratory, based on $\mathrm{K}_{\mathrm{d}}$ and soil properties, are 300 and $200 \mathrm{mg} / \mathrm{L}$, respectively. These $\mathrm{K}_{\mathrm{d}}$-controlled concentrations are also thought to be much higher than expected. However, the highsolubility limit was used in this analysis to determine if lead accounts for a large portion of the risk. These conservative numbers did not result in high risk numbers for lead, so refinements to the solubility limits were not required.

\section{B.3 Contaminant-Sorption Coefficients}

The MEPAS chemical database (augmented from that reported in Strenge and Peterson [1989] by adding more contaminants and updating some parameter values) contains information needed to calculate contaminant-sorption coefficients from the physical and chemical properties of the soil. For organic chemicals, the database tabulates values of the carbon matter partition coefficient and octanol-water partition coefficient for each contaminant. The $\mathrm{K}_{\mathrm{d}}$ value can be calulated from either of these values, using the organic carbon content of the soil (and a correlation equation if the octanol-water partition coefficient is used). For contaminants other than organic chemicals, the database contains a set of $\mathrm{K}_{\mathrm{d}}$ values for each contaminant that vary, depending on the soil $\mathrm{pH}$ and total weight percent of clay, organic matter, and iron and aluminum oxyhydroxides. If information needed to calculate a $\mathrm{K}_{\mathrm{d}}$ value for a specific contaminant was not available in the MEPAS database, the contaminant was initially assigned a conservative value of zero. $\mathrm{K}_{\mathrm{d}}$ values calculated from these MEPAS database parameters/methods are assumed as default values unless better site-specific information was available.

The MEPAS database parameters were used directly to compute $K_{d}$ values for the organic contaminants. However, an attempt was made to improve the validity of the MEPAS inorganic $K_{d}$ values by finding site-specific $K_{d}$ values for the various sites under study. Adsorption phenomenology for inorganic contaminants is not well understood, based on first principles; the most acceptable approach to quantifying adsorption is to use site-specific studies as opposed to generic literature, when possible. Site geochemists were contacted at the sites under study; several documents were obtained that contain site-specific $K_{d}$ values for some contaminants; and, in a few cases, unpublished information was used on site preferences for $K_{d}$ values for near-surface soils and natural waters (the closest scenario to expected leachate from a solid-waste-burial ground for all but cement-stabilized wastes). The site-specific references consulted were Brookins (1984), Davis et 
al. (1984), Dickie (personal communication), Hietanen et al. (1985), Kaplan and Serne (1995), Kaplan et al. (1995), Looney et al. (1987), Serne et al. (1993), Sheppard et al. (1984), Sheppard and Thibault (1990), Triay et al. (1994), and Wolfsberg (1980). In addition to the information received from the site, some chemical analog assumptions were invoked to generate lessconservative (i.e., nonzero) $\mathrm{K}_{\mathrm{d}}$ values for rare elements that are chemically quite similar to elements for which $\mathrm{K}_{d}$ data were available (e.g., curium is similar to americium, praseodymium is similar to europium, etc).

These site-specific and chemical analog $\mathrm{K}_{\mathrm{d}}$ values were used to create an alternative lookup table to compare with the MEPAS database values. Site-specific $K_{d}$ values were used when they were available and the chemical analog $K_{d}$ values were used instead of conservative zero values. If neither of these two values were available, the MEPAS database values were used. If neither sitespecific, chemical analog, nor MEPAS database values were available, a conservative zero value was used in the calculations. The final radionuclide and inorganic $<K_{d}$ values for each soil type for each environmental setting are shown in Table B.3.

\section{B.4 Contaminant-Diffusion Coefficients in Cement}

The methods for modeling contaminant release from cemented waste forms depend on contaminant-specific cement-diffusion coefficients. The cement-diffusion-coefficient values used in the No-Action Alternative 2 analyses were obtained from the MEPAS chemical database. This database (augmented from that reported in Serne and Wood [1990]) contains cemented waste-form effective diffusion coefficients for most of the contaminants of concern. These database values were reviewed for consistency, given that new literature has been obtained since its original creation. The only changes made involved improving overly conservative values for curium and neptunium. Curium was given a value similar to more-common actinides by using the concept of chemical analogs that indicates that effective diffusion coefficients of chemically similar elements should be the same. The value for neptunium was changed, based on observations that neptunium does not leach from cements/grouts and, thus, should have an effective diffusion coefficient similar to the other actinides as opposed to a high value like nitrate. Neptunium leach data are found in Ew̧art et al. (1986, 1992).

If values were not available in the MEPAS chemical database and a chemical analog was not available, the contaminant was assigned a conservatively high value of $5.0 \mathrm{E}-08 \mathrm{~cm}^{2} / \mathrm{s}$. Organic contaminants are typically not well immobilized by cement and are also assigned a value of $5.0 \mathrm{E}-08 \mathrm{~cm}^{2} / \mathrm{s}$. The final list of cement-diffusion coefficients used in the analyses is shown in Table B.4. 
Tạble B.3. $K_{d}$ Values Used in No Action Alternative 2 Analyses (milliliters of water/gram of soil)

\begin{tabular}{|c|c|c|c|c|c|c|c|c|c|c|c|c|}
\hline Contaminant & \begin{tabular}{|c|} 
Hanford, All \\
Zones, Both \\
Settings \\
\end{tabular} & $\begin{array}{c}\text { ORNL, PZ1, } \\
\text { PZ3, sZ } \\
\end{array}$ & ORNL, PZ2 & ORNL, PZ4 & LANL, PZI & $\begin{array}{c}\text { LANL, PZ2, } \\
\text { PZ3, SZ }\end{array}$ & SRS, All Zones & INEL, PZ1, PZ3 & $\begin{array}{l}\text { INEL, PZ2, } \\
\text { PZ4, SZ }\end{array}$ & Rocky PZ & Rocky SZ & $\begin{array}{l}\text { LLNL, All } \\
\text { iZones }\end{array}$ \\
\hline Lead & 1000 & 597 & 10 & 12.1 & 25 & 25 & 100 & 597. & 234 & 1830 & 234 & 597 \\
\hline Mercury & 322 & 580 & 60 & 500 & 5280 & 580 & 10000 & 580 & 322 & 5280 & 322 & 580 \\
\hline Beryllium & 70 & 1400 & 140 & 800 & 8000 & 1400 & 140 & 1400 & 70 & 8000 & 70 & 1400 \\
\hline Cadmium & 14.9 & 423 & 42.9 & 100 & 567 & 423 & 6.3 & 423 & 14.9 & 567 & 14.9 & 423 \\
\hline AC225 & 228 & 538 & 6 & 6 & 4600 & 538 & 6 & 538 & 228 & 4600 & 228 & 538. \\
\hline AC227 & 228 & 538 & 6 & 6 & 4600 & 538 & 6 & 538 & 228 & 4600 & 228 & 538 \\
\hline AC228 & 228 & 538 & 6 & 6 & 4600 & 538 & 6 & 538 & 228 & 4600 & 228 & 538 \\
\hline AG109M & 10 & 4 & 4 & 6 & 40 & 4 & 4 & 4 & 0.4 & 40 & 0.4 & 580 \\
\hline AGIIO & 10 & 4 & 4 & 6 & 40 & 4 & 4 & 4 & 0.4 & 40 & 0.4 & 580 \\
\hline AGIIOM & 10 & 4 & 4 & 6 & 40 & 4 & 4 & 4 & 0.4 & 40 & 0.4 & 580 \\
\hline $\mathrm{AM} 24 \mathrm{I}$ & 82 & 5670 & 200 & 1000 & 130 & 130 & 100 & 200 & 82 & 1000 & 82 & 200 \\
\hline AM243 & 82 & 5670 & 200 & 1000 & 130 & 130 & 100 & 200 & 82 & 1000 & 82 & 200 \\
\hline AM245 & 82 & 5670 & 200 & 1000 & 130 & 130 & 100 & 200 & 82 & . 1000 & 82 & 597 \\
\hline AT217 & Conservative o & Conservative o & Conservative 0 & Conservative 0 & Conservative 0 & Conservative 0 & Conservative 0 & Conservative 0 & Conservative 0 & Conservative 0 & Conservalive 0 & Conservative 0 \\
\hline BA137M & 530 & 2800 & 280 & 1600 & 946 & 946 & 280 & 2800 & 530 & 16000 & 530 & 2800 \\
\hline B1210 & 234 & 597 & 10 & 12 & 1830 & 597 & 10 & 597 & 234 & 1830 & 234 & 597 \\
\hline B1211 & 234 & 597 & 10 & 12 & 1830 & 597 & 10 & 597 & 234 & 1830 & 234 & 597 \\
\hline 81212 & 234 & 597 & 10 & 12 & 1830 & 597 & 10 & 597 & 234 & 1830 & 234 & 597 \\
\hline BI213 & 234 & 597 & 10 & 12 & 1830 & 597 & 10 & 597 & 234 & 1830 & 234 & 597 \\
\hline B1214 & 234 & 597 & 10 & 12 & 1830 & 597 & 10 & 597 & 234 & 1830 & 234 & 597 \\
\hline BK249 & 82 & Conservative o & Conservative 0 & Conservative 0 & Conservative 0 & Conservative 0 & Conservative 0 & Conservative 0 & Conservative 0 & Conservalive 0 & Conservative 0 & Conservalive 0 \\
\hline BK250 & 82 & Conservative 0 & Conservative 0 & Conservative 0 & Conservative 0 & Conservative 0 & Conservalive 0 & Conservalive 0 & Conservative 0 & Conservalive 0 & Conservative 0 & Conservative 0 \\
\hline $\mathrm{Cl} 4$ & 0 & 0 & 0 & 0 & 0 & 0 & 0.01 & 0 & 0 & 0 & 0 & 0 \\
\hline CD109 & 14.9 & 423 & 42.9 & 100 & 567 & 423 & 6.3 & 423 & 14.9 & 567 & 14.9 & 423 \\
\hline CDI13M & 14.9 & 423 & 42.9 & 100 & 567 & 423 & 6.3 . & 423 & 14.9 & 567 & 14.9 & 423 \\
\hline CEI44 & 288 & 538 & 6 & 6 & 4600 & 538 & 1000 & 538 & 288 & 4600 & 288 & 538 \\
\hline CF249 & 82 & Conservative 0 & Conservative o & Conservative 0 & 50 & 50 & Conservative 0 & Conservative 0 & Conservative 0 & Conservative 0 & Conservative 0 & Conservative 0 \\
\hline CF250 & 82 & Conservative 0 & Conservative 0 & Conservative 0 & 50 & 50 & Conservative 0 & \begin{tabular}{|l|} 
Conservative 0 \\
\end{tabular} & Conservative 0 & Conservative 0 & Conservative 0 & Conservative 0 \\
\hline CF251 & 82 & Conservative 0 & Conservative 0 & Conservative 0 & 50 & 50. & Conservative 0 & Conservative 0 & Conservative 0 & Conservative 0 & Conservative 0 & Conservative 0 \\
\hline CF252 & 82 & Conservative 0 & Conservative 0 & Conservative 0 & 50 & 50 & Conservative 0 & Conservative 0 & Conservative 0 & Conservative 0 & Conservative 0 & Conservalive 0 \\
\hline CM242 & 82 & Conservative 0 & Conservative 0 & Conservative 0 & 50 & 50 & 3000 & 4000 & 4000 & Conservative 0 & Conservative 0 & Conservative 0 \\
\hline CM243 & 82 & Coniservative 0 & Conservative 0 & Conservative 0 & 50 & $50^{\circ}$ & 3000 & 4000 & 4000 & Conservative 0 & Conservative 0 & Conservative 0 \\
\hline
\end{tabular}




\begin{tabular}{|c|c|c|c|c|c|c|c|c|c|c|c|c|}
\hline$\angle 65$ & $\forall \varepsilon \Sigma$ & $0 \varepsilon 81$ & $D E Z$ & $\angle 65$ & 01 & $\angle 65$ & $0 £ 81$ & $t z t$ & 01 & $\angle 65$ & 0001 & 6028d \\
\hline 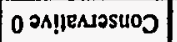 & 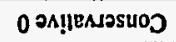 & O OAIIEANOSLOS & oss & oss & 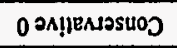 & 001 & 001 & 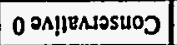 & 0 อง!lensosuOJ & 0 OA!|BEAJSUOO & 0 อง!!EnesนOJ & WtEŹVd \\
\hline 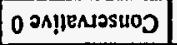 & 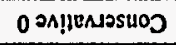 & 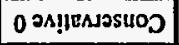 & OSS & oss & 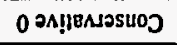 & 001 & 001 & 0 อม!|вMNOSUOJ & 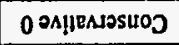 & 0 ON!!ERAOSUOJ & 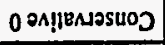 & tezVd \\
\hline 0 әм!ाentosutos & 0 วก!̣וENอง & 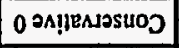 & oss & . OSS & O DК!!ENESHOJ & 001 & 001 & 0 OA!jEATOSHOO & 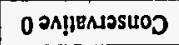 & 0 วA!!EnasuOJ & 0 อง!!|ENasนOO & 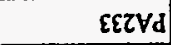 \\
\hline 0 อง!̣|ENOSLOS & 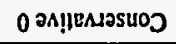 & 0 อง!̣|ENIOSUOS & oss & OSS & 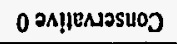 & 001 & 001 & 0 OA!jeñSUOS & 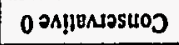 & 0 әм!̣enassuoj & 0 әn!̣enasuoj & IEZVd \\
\hline 0 อN!̣|ENosuos & o ON!!IENOSLOJ & 0 OM!!|EANOSUOJ & $s$ & $s$ & 01 & $100^{\circ} 0$ & $100^{\prime} 0$ & 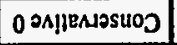 & O OA!IENSOSUOO & 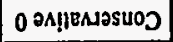 & 62 & WObZdN \\
\hline 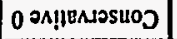 & 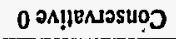 & 0 อA!!EANOSUOJ & $s$ & $s$ & 01 & $100^{\circ} 0$ & $\cdot 100^{\circ} 0$ & 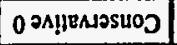 & O PSIIENSOSUOS & O OA!IENASSUOJ & t'z & ObZdN \\
\hline 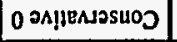 & 0 อN!ן|ENOSHOS & 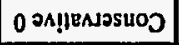 & $s$ & $s$ & 01 & $100^{\prime} 0$ & $100^{\prime} 0$ & o os!lyessosuos & 0 วA!jeñOSLOJ & 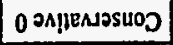 & $1 \%$ & $6 \mathfrak{Z Z d N}$ \\
\hline 0 a & 0 әм!̣!enasuos & 0 ว & $s$ & $s$ & 01 & $100^{\circ} 0$ & $100^{\circ} 0$ & O OAMEANSSUOOS & O PN!ןEANOSUOS & 0 PA!̣EARSUOO & $p 2$ & LEZdN \\
\hline 9'85 & z'zl & OS9. & $2 ' z 1$ & 9.85 & 001 & OS & OS & 59 & $98^{\prime} \mathrm{S}$ & 9.85 & $22 !$ & E9IN \\
\hline 985 & 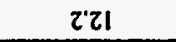 & OS9. & $2 ' z I$ & 9.85 & 001 & 05 & OS & s9 & $98^{\circ} \mathrm{S}$ & 9.85 & 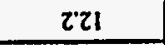 & GSIN \\
\hline 001 & OS & 001 & OS & 001 & 001 & 001 & 001 & 001 & 001 & 001 & 05 & WS68N \\
\hline 001 & 05 & 001 & OS & 001 & 001 & 001 & 001 & 001 & 001 & 001 & os & $569 \mathrm{~N}$ \\
\hline$\varepsilon s \tau$ & S'91 & 6.98 & $S ' 91$ & $\varepsilon ' s \tau$ & $s z$ & $\varepsilon\llcorner s \tau$ & $69 \varepsilon$ & $\forall$ & $s^{\prime} z$ & $\varepsilon ' s \tau$ & $s^{\prime 91}$ & DSNW \\
\hline 0 & 0 & 0 & 0 & 0 & 2,0 & 0 & 0 & 0 & 0 & Lill & $L^{\prime} 0$ & 6ZII \\
\hline 0 & $\mathbf{0}$ & 0 & 0 & 0 & 0 & 0 & 0 & 0 & 0 & 0 & 0 & $\varepsilon \mathrm{H}$ \\
\hline 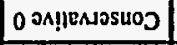 & 0 วм!̣!enosuoj & 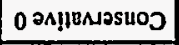 & 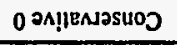 & O Oก!jensosuoj & 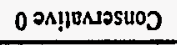 & 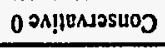 & 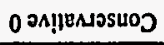 & 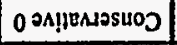 & O OA!jEALOSLOO & 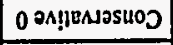 & 0 anjpenasuos & Ezटds \\
\hline O & O OR!IENOSLOJ & 0 อม!!|EATOSLOO & 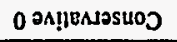 & O PA!IENASSLOOJ & 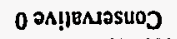 & O OA!IENAOSUOOJ & 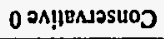 & O & 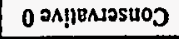 & 0 ox!lEenassuOJ & 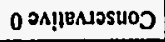 & IZZdA \\
\hline sl & sl & sI & sI & $s 1$ & 01 & SI & SI & 621 & 01 & 0089b & sl & 6S9J \\
\hline sI & st & $s t$ & st & st & 01 & $\$$ & SI & 621 & 01 & 00896 & SI & SS9I \\
\hline $8 \varepsilon S$ & $8 z 2$ & $009 b$ & $8 i z$ & $8 \varepsilon S$ & 9 & OS & os & 9 & 9 & $8 E S$ & $8 z 2$ & ssing \\
\hline $8 \varepsilon 5$ & 872 & 0096 & 822 & $8 E S$ & 9 & 05 & os & 9 & 9 & $8 E S$ & $8 z 2$ & tSIng \\
\hline $8 \varepsilon 5$ & 822 & 009b & 822 & $8[S$ & $\dot{9}$ & OS & $0 S$ & 9 & 9 & $8 \varepsilon 5$ & 822 & $2 \sin \theta$ \\
\hline $8 \varepsilon S$ & 822 & 0096 & $8 z 2$ & $8 \varepsilon S$ & 9 & OS & OS & 9 & 9 & $8 E S$ & 822 & osing \\
\hline 602 & Is & $0<2$ & is & $S L$ & 105 & 602 & 825 & $\angle 2$ & 602 & $000+9$ & $00 \varepsilon$ & LEIS \\
\hline 602 & IS & $0<\tau$ & is & $S L$ & 105 & $6 b 2$ & 870 & $\iota 2$ & $6 \circ \tau$ & 00069 & OOE & SEISO \\
\hline 602 & is & $0<2$ & is & $S L$ & 105 & 602 & 820 & $\angle 2$ & 602 & 00069 & OOE & $t$ tEISJ \\
\hline 18.8 & \pm 61 & 002 & 46.1 & 18.8 & ol & 18.8 & $00 z$ & $\tau^{\circ} 0$ & $6 \%$ & $08 L$ & 001 & 0903 \\
\hline 18.8 & $\forall 6.1$ & $00 \tau$ & 061. & $18 \cdot 8$ & 01 & 18.8 & 002 & $\tau_{0}$ & 60 & $08 L$ & 001 & 8500 \\
\hline 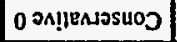 & 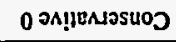 & 0 On!jentasuoj & 0006 & $000 b$ & $000 \varepsilon$ & os & 05 & O On!ןeñsuos & 0 อง!yeñs & 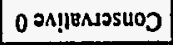 & 28 & $862 W 3$ \\
\hline 0 วм!ן & 0 อง!lENAOSLOO & 0 DA!IENASUOO & 0008 & $000 t$ & $000 \varepsilon$ & OS & os & 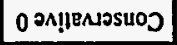 & 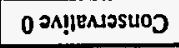 & 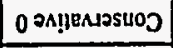 & 28 & ८०2W \\
\hline 0 อм!̣|еNosuos & 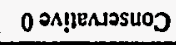 & 0 อม!!ENIOSUOJ & $000 t$ & 0006 & $000 \varepsilon$ & OS & os & 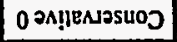 & 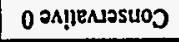 & 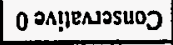 & 28 & $982 w 3$ \\
\hline 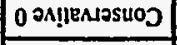 & 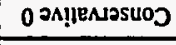 & 0 อง!̣ENASSUOJ & $000 t$ & $000 b$ & $000 \varepsilon$ & OS & os & 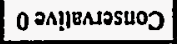 & 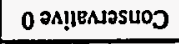 & 0 әм!genassuoj & 28 & stzwo \\
\hline 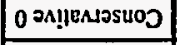 & 0 DN!jenNOSUOJ & 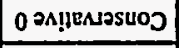 & $000 b$ & 0008 & $000 \varepsilon$ & OS & OS & 0 anigenasuos & 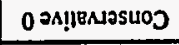 & 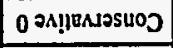 & 28 & Dเ2W0 \\
\hline $\begin{array}{c}\text { sэuoz } \\
\text { แIV 'TNרT }\end{array}$ & 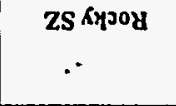 & Zd אYุơ & $\begin{array}{c}\text { ZS'bZd } \\
\text { 'ZZd'TaNI }\end{array}$ & EZd 'IZd 'TGNI & səu0Z IIV 'SYS & $\begin{array}{c}\text { ZS 'EZd } \\
\text { 'ZZd 'TNV' }\end{array}$ & IZd 'TNYT & 6Zd'TNZO & - IZd'TN\&O & \begin{tabular}{|c|} 
Zs'EZd \\
'IZd'INYO
\end{tabular} & 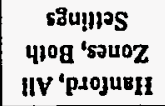 & 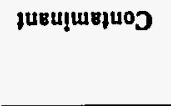 \\
\hline
\end{tabular}




\begin{tabular}{|c|c|c|c|c|c|c|c|c|c|c|c|c|}
\hline 9 & 2 & 6.51 & $z$ & 9 & $s$ & 9 & $6 \mathrm{SI}$ & $6 \mathrm{SI}$ & $s$ & 9 & 2 & szigs \\
\hline ISE & $\nabla<2$ & 069 & $p L Z$ & ISE & $8 S 1$ & ISE & 069 & 92 & 92 & ISE & 12 & $90 \ln 8$ \\
\hline 0 әм!̣passuos & 0 อม!ाENAOSUOO & 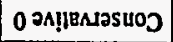 & 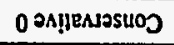 & 0 อม!̣EAJSLOJ & 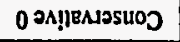 & 0 จx!̣ensosuos & O DẠוgANSSUOJ & O OA!gentSsLOS & O OA!ןBASOSUOS & O OM!IENSOSUOS & 0 os!lensosuOJ & ZZZNQ \\
\hline 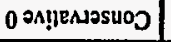 & 0 әx!̣eniosuos & 0 อs!lendosuo & 0 อs!jenesuoj & o คn!̣E்Nosน0ว & 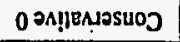 & 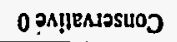 & 0 OA!gENOSUOOJ & 0 วA!fEANOSLOO & 0 อม!!ENIOSUOO & 0 OA!jENSOSUOO & 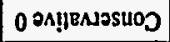 & 0ZZNY \\
\hline O PM!|lENOSHOJ & 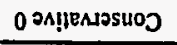 & 0 วN!!ENASSUOJ & 0 PA!|ENAOSHOJ & 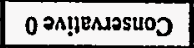 & 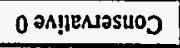 & 0 อง!̣ensosuoJ & 0 อN!IIENAOSHOOJ & 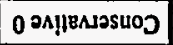 & 0 ON!ןEATSSUOS & 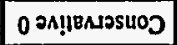 & 0 2N!IERASSUOJ & 6IZNA \\
\hline o כa!pgansuos & 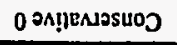 & O OA!IENAOSUOD & 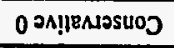 & 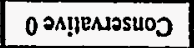 & 0 PN!IENAOSUOJ & O DA!IENSOSUOJ & 0 2a!̣eñosuOJ & 0 วм!ן⿴囗十assuos & 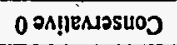 & 0 әм!! & 01 & 901Hd \\
\hline 001 & $\varepsilon \varepsilon^{\prime}$ & $B 21$ & $\varepsilon t b z$ & 001 & 001 & 001 & 002 & $\Delta z I$ & 001 & 001 & $\varepsilon " b \tau$ & $8227 \mathrm{~d}$ \\
\hline 001 & $\varepsilon " b z$ & $\mathrm{tZI}$ & 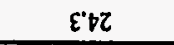 & 001 & 001 & 001 & 002 & b'zl & $00 I$ & 001 & $\varepsilon$ & $922 \mathrm{Vd}$ \\
\hline 001 & 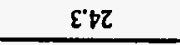 & $\mathrm{BZI}$ & 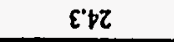 & 001 & 001 & 001 & 002 & $\Delta 21$ & 001 & 001 & $\varepsilon " b \tau$ & SZZVA \\
\hline 001 & $\varepsilon$ & $\mathbf{D Z I}$ & $\varepsilon " \hbar \tau$ & 001 & $00 \mathrm{I}$ & 001 & 002 & $\nabla Z I$ & 001 & 001 & $\varepsilon^{\prime \prime} \forall z$ & $\neg 2 z V \mathrm{~d}$ \\
\hline 001 & $\varepsilon " b z$ & $\forall 21$ & $\varepsilon " \nabla \tau$ & 001 & 001 & 001 & 002 & $\phi Z I$ & 001 & 001 & $\varepsilon^{\prime} b \tau$ & EZZV \\
\hline 001 & 01 & $0 s z$ & 01 & 001 & 001 & 001 & 011 & $\varepsilon p$ & 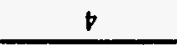 & 001 & 08 & strnd \\
\hline 001 & 01 & $0 s 2$ & 01 & 001 & 001 & 001 & 011 & $\mathfrak{E P}$ & $t$ & 001 & 08 & etrnd \\
\hline 001 & 01 & $0 s z$ & 01 & 001 & 001 & 001 & 011 & $\varepsilon b$ & $t$ & 001 & 08 & $z \not z \cap n d$ \\
\hline 001 & 01 & ost & OI & 001 & 001 & 001 & 011 & $\varepsilon b$ & $b$ & 001 & 08 & Ibznd \\
\hline 001 & 01 & $0 \varsigma \Omega$ & 01 & 001 & 001 & 001 & 011 & $\varepsilon \boldsymbol{b}$ & 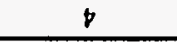 & 001 & 08 & otzend \\
\hline $001^{\circ}$ & 01 & osz & 01 & 001 & 001 & 001 & oll & $\mathfrak{E}$ & $t$ & 001 & 08 & 6£znd \\
\hline 001 & 01 & osz & 01 & 001 & 001 & 001 & 011 & $\varepsilon b$ & $t$ & 001 & 08 & $8 \varepsilon z \cap d$ \\
\hline 001 & 01 & $0 s z$ & 01 & 001 & 001. & 001 & 011 & $\mathfrak{\varepsilon t}$ & $t$ & 001 & 08 & 9\&Znd \\
\hline 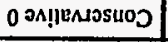 & 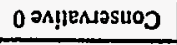 & 0 ON!IIENOSLOO & 005 & $00 S$ & O DM!IENAOSLOJ & O SA!|BNASSUOS & O 2A!jEASSHOD & 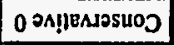 & o ON!!ENSOSUOD & 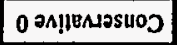 & 01 & btI tdd \\
\hline 601 & $6 \% \mathrm{~S}$ & 6.61 & 6.5 & 601 & oop & 6.01 & 6.11 & 6.61 & 6.61 & 6.61 & 6.5 & $8120 d$ \\
\hline $6 \$ 1$ & 6.5 & 6.61 & 6.5 & 601 & 000 & 6.61 & 6.61 & 601 & 6061 & 601 & 6.5 & $9120 \mathrm{~d}$ \\
\hline 601 & 6.5 & 6.01 & $6 \mathrm{~S}$ & 6.61 & 000 & 601 & $6 ' b I$ & 601 & 601. & 6.61 & 6.5 & sIzOd \\
\hline 60.1 & 6.5. & 601 & 6.5 & 601 & 000 & $6+1$ & 6.01 & 6001 & 6.01 & 6.61 & $6 " s$ & $1120 d$ \\
\hline 601 & 6.5 & 6.61 & 6.5 & 601 & oop & 601 & 6.61 & 6011 & 6061 & 6.61 & 6.5 & ElzOd \\
\hline 6.01 & 6.5 & 6.61 & 6.5 & 601 & oob & 601 & 601 & 6.61 & 601 & 601 & $6 \mathrm{~s}$ & $2120 d$ \\
\hline 6.51 & 6.5 & $6 . \mathrm{bl}$ & $6 \mathrm{~S}$ & 601 & 000 & 601 & 6.61 & 6.61 & 6.61 & 6.01 & 6.5 & $1120 \mathrm{~d}$ \\
\hline 6.11 & $6 \mathrm{~S}$ & 6.01 & 6.5 & 601 & 006 & 601 & 601 & 601 & 6.81 & 6.51 & 6.5 & $0120 \mathrm{~d}$ \\
\hline 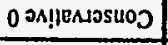 & 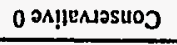 & 0 อง!̣ensosuos & 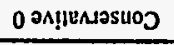 & 0 อก!!|ENosuoJ & 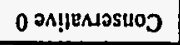 & 0 อง!̣|eNsosuos & O ON!|ENasLOOJ & O כM!!ENAOSUOJ & O OA!!ERAOSUOO & 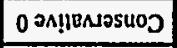 & 01 & $\angle t I W d$ \\
\hline 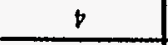 & b0 & $0 b$ & $\forall 0$ & $t$ & $\bullet$ & os & os & $\varepsilon^{\prime} 6 \varepsilon$ & 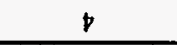 & $b$ & 01 & $\angle 01 \mathrm{~d}_{\mathrm{d}}$ \\
\hline$\angle 65$ & $p \varepsilon \tau$ & $0 \varepsilon 81$ & $\mathbb{D E Z}$ & $\angle 6 S$ & 01 & LGS & $0 \varepsilon 81$ & $|z|$ & 01 & $\angle 6 S$ & 0001 & $612 \mathrm{gd}$ \\
\hline$\angle 6 S$ & $D E Z$ & $0 £ 81$ & $\forall E Z$ & $\angle 65$ & 01 & $\angle 6 S$ & $0 \varepsilon 81$ & I'ZI & 01 & $\angle G S$ & 0001 & $2128 \mathrm{~d}$ \\
\hline$\angle 6 S$ & เEZ & $0 £ 81$ & $\forall \varepsilon Z$ & $\angle 65$ & $0 !$ & $\angle 65$ & $0 £ 81^{\circ}$ & $|z|$ & 01 & $\angle 6 S$ & 0001 & $1128 d$ \\
\hline$\angle 65$ & $\therefore \quad$ DEZ & $0 £ 81$ & PEZ & $\angle 6 S$ & 01 & $\angle 6 S$ & $0 \varepsilon 81$ & I'zl & 01 & $\angle 6 S$ & 0001 & $0128 \mathrm{~d}$ \\
\hline $\begin{array}{c}\text { souo' } \\
\text { IIV 'TNTT }\end{array}$ & ZS КभगоY & Żd אY⿻o: & $\begin{array}{c}\text { ZS' }+Z d \\
\text { 'ZZd'TINI }\end{array}$ & EZd 'IZd'7รNI & sauoZ IIV'SUS & $\begin{array}{c}\text { ZS'EZd } \\
\text { 'zZd'TNVT }\end{array}$ & IZd'TNVT & DZd 'TN\&O & $\begin{array}{c}\text { ZZd'TNHO } \\
\text {. }\end{array}$ & $\begin{array}{c}\text { ZS'CZd } \\
\text { 'IZd'INHO }\end{array}$ & 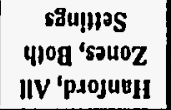 & зивцุщв јиор \\
\hline
\end{tabular}


Table B.3. (Contd)

\begin{tabular}{|c|c|c|c|c|c|c|c|c|c|c|c|c|}
\hline Contaminant & $\begin{array}{l}\text { Hanford, All } \\
\text { Zones, Both } \\
\text { Settings }\end{array}$ & $\begin{array}{c}\text { ORNL, PZ1, } \\
\text { PZ3, SZ }\end{array}$ & ORNL, PZ2 & ORNL, PZ4 & LANL, PZI & $\begin{array}{c}\text { LANL, PZ2, } \\
\text { PZ3, SZ }\end{array}$ & SRS, All Zones & INEL, PZI, PZ3 & $\begin{array}{c}\text { INEL, PZ2, } \\
\text { PZ4, SZ }\end{array}$ & Rocky PZ & Rocky SZ & $\begin{array}{c}\text { LLNL, AII } \\
\text { Zones }\end{array}$ \\
\hline SB126 & 2 & 6 & 5 & 15.9 & 15.9 & 6 & 5 & 6 & 2 & 15.9 & 2 & 6 \\
\hline SB126M & 2 & 6 & 5 & 15.9 & 15.9 & 6 & 5 & 6 & 2 & 15.9 & 2 & 6 \\
\hline SE79 & 0 & 14.9 & 14.9 & 14.9 & 2 & 2 & 2.5 & 14.9 & 5.91 & 14.9 & 5.91 & 14.9 \\
\hline SM1S1 & 228 & 538 & 6 & 6 & 50 & 50 & 6 & 538 & 228 & 4600 & 228 & 538 \\
\hline SN119M & 100 & 10 & 5 & 5 & 50 & 10 & 100 & 10 & 5 & 10 & 5 & 10 \\
\hline SNI21M & 100 & 10 & 5 & 5 & 50 & 10 & 100 & 10 & 5 & 10 & 5 & 10 \\
\hline SN126 & 100 & 10 & 5 & 5 & 50 & 10 & .100 & 10 & 5 & 10 & 5 & 10 \\
\hline$\overline{S R 90}$ & 24.3 & 494 & 100 & 12.4 & 116 & 100 & 7.9 & 8.3 & 8.3 & $\begin{array}{ll}\cdot 124 \\
\end{array}$ & 24.3 & 100 \\
\hline TC99 & 0 & 20 & 20 & 20 & 0.3 & 0.3 & 0.001 & 0.1 & 0.1 & 20 & 3 & 20 \\
\hline TE125M & Conservative 0 & Conservative 0 & Conservative 0 & Conservative 0 & Conservative 0 & Conservative 0 & \begin{tabular}{|c|} 
Conservative 0 \\
\end{tabular} & 125 & 125 & Conservative 0 & Conservative 0 & Conservative 0 \\
\hline$\overline{T E 127}$ & Conservative 0 & Conservalive 0 & Conservative 0 & Conservative 0 & Conservative 0 & Conservative 0 & Conservative 0 & 125 & 125 & Conservative 0 & \begin{tabular}{|c|} 
Conservative 0 \\
\end{tabular} & Conservative 0 \\
\hline TE127M & Consecrvative 0 & \begin{tabular}{|l|} 
Conservative 0 \\
\end{tabular} & \begin{tabular}{|l|} 
Conservalive 0 \\
\end{tabular} & \begin{tabular}{|l|} 
Conservative 0 \\
\end{tabular} & \begin{tabular}{|l|} 
Conservative 0 \\
\end{tabular} & \begin{tabular}{|l|} 
Conservative 0 \\
\end{tabular} & \begin{tabular}{|l|} 
Conservative 0 \\
\end{tabular} & 125 & 125 & Conservative 0 & \begin{tabular}{|l|} 
Conservalive 0. \\
\end{tabular} & \begin{tabular}{|l} 
Conservative 0 \\
\end{tabular} \\
\hline TH227 & 100 & 500 & 60 & 100 & 500 & 500 & 100 & 500 & 100 & 2700 & 100 & 500 \\
\hline TH228 & 100 & 500 & 60 & 100 & 500 & 500 & 100 & 500 & 100 & 2700 & 100 & 500 \\
\hline TH229 & 100 & 500 & 60 & 100 & 500 & 500 & 100 & 500 & 100 & 2700 & 100 & 500 \\
\hline TH1230 & 100 & 500 & 60 & 100 & 500 & 500 & 100 & 500 & 100 & 2700 & 100 & 500 \\
\hline T71231 & 100 & 500 & 60 & 100 & 500 & 500 & 100 & 500 & 100 & 2700 & 100 & 500 \\
\hline$\pi 1232$ & 100 & 500 & 60 & 100 & 500 & .500 & 100 & 500 & 100 & 2700 & 100 & 500 \\
\hline $\overrightarrow{\mathrm{TH} 234}$ & 100 & 500 & 60 & 100 & 500 & 500 & 100 & 500 & 100 & 2700 & 100 & 500 \\
\hline $\mathrm{TL} 207$ & 0 & 0.2 & 0 & 0 & 0.8 & 0.2 & 0 & 0.2 & 0 & 0.8 & 0 & 0.2 \\
\hline$\pi 208$ & 0 & 0.2 & 0 & 0 & 0.8 & 0.2 & 0 & 0.2 & 0 & 0.8 & 0 & 0.2 \\
\hline$\pi 209$ & 0 & 0.2 & 0 & 0 & 0.8 & 0.2 & 0 & 0.2 & 0 & 0.8 & 0 & 0.2 \\
\hline $\mathrm{U} 232$ & 0.1 & 50 & 5 & 50 & 1.8 & 1.8 & 40 & 50 & 0 & 500 & 0 & 50 \\
\hline U233 & 0.1 & 50 & 5 & 50 & 1.8 & 1.8 & 40 & 50 & 0 & 500 & 0 & 50 \\
\hline U234 & 0.1 & 50 & 5 & 50 & 1.8 & 1.8 & 40 & 50 & 0 & 500 & 0 & 50 \\
\hline U235 & 0.1 & 50 & 5 & 50 & 1.8 & 1.8 & 40 & 50 & 0 & 500 & 0 & 50 \\
\hline U236 & 0.1 & 50 & 5 & 50 & 1.8 & 1.8 & 40 & 50 & 0 & 500 & 0 & 50 \\
\hline U237 & 0.1 & 50 & 5 & 50 & 1,8 & 1.8 & 40 & 50 & 0 & 500 & 0 & 50 \\
\hline U238 & 0.1 & 50 & 5 & 50 & 1.8 & 1.8 & 40 & 50 & 0 & 500 & 0 & 50 \\
\hline U240 & 0.1 & 50 & 5 & 50 & 1.8 & 1.8 & 40 & 50 & 0 & 500 & 0 & 50 \\
\hline$Y 90$ & 228 & 538 & 6 & 6 & 4600 & 538 & 6 & 538 & 228 & 4600 & 228 & 538 \\
\hline 2N65 & 12.7 & 939 & 280 & 280 & 1460 & 939 & 16 & 939 & 12.7 & 1460 & 12.7 & 939 \\
\hline
\end{tabular}


Table B.4. Grout-Diffusion Coefficient Used for No Action Alternative 2 Analyses

\begin{tabular}{|l|l|}
\hline \multicolumn{1}{|c|}{ Contminant } & \multicolumn{1}{|c|}{$\begin{array}{c}\text { Grout-Diffusion Coeffcient } \\
\left.\text { (cm }{ }^{2} / \mathbf{s}\right)\end{array}$} \\
\hline Americium-241 & $5.0 \mathrm{E}-13$ \\
\hline Americium-243 & $5.0 \mathrm{E}-13$ \\
\hline Carbon-14 & $1.0 \mathrm{E}-12$ \\
\hline Curium-243 & $5.0 \mathrm{E}-11$ \\
\hline Curium-244 & $5.0 \mathrm{E}-11$ \\
\hline Cesium-137 & $5.0 \mathrm{E}-10$ \\
\hline Europium-152 & $5.0 \mathrm{E}-11$ \\
\hline Neptunium-237 & $5.0 \mathrm{E}-10$ \\
\hline Protactinium-233 & Conservative 5.0E-08 \\
\hline Plutonium-238 & $5.0 \mathrm{E}-11$ \\
\hline Plutonium-239 & $5.0 \mathrm{E}-11$ \\
\hline Plutonium-240 & $5.0 \mathrm{E}-11$ \\
\hline Plutonium-241 & $5.0 \mathrm{E}-11$ \\
\hline Radium-226 & $5.0 \mathrm{E}-11$ \\
\hline Stontium-90 & $5.0 \mathrm{E}-11$ \\
\hline Uranium-233 & $1.0 \mathrm{E}-12$ \\
\hline Uranium-234 & $1.0 \mathrm{E}-12$ \\
\hline Uranium-235 & $1.0 \mathrm{E}-12$ \\
\hline Lead & $1.0 \mathrm{E}-11$ \\
\hline Beryllium & $5.0 \mathrm{E}-10$. \\
\hline Cadmium & $5.0 \mathrm{E}-10$ \\
\hline Mercury & $5.0 \mathrm{E}-11$ \\
\hline Carbon tetrachloride & Conservative 5.0E-08 \\
\hline Chloroform & Conservative 5.0E-08 \\
\hline Methylene chloride & Conservative 5.0E-08 \\
\hline Carbon disulfide & Conservative 5.0E-08 \\
\hline $1,1-D i c h l o r o e t h y l e n e ~$ & Conservative 5.0E-08 \\
\hline Methyl ethyl ketone & Conservative 5.0E-08 \\
\hline 1,1,2,2-Tetrachloroethane & Conservative 5.0E-08 \\
\hline Toluene & Conservative 5.0E-08 \\
\hline Chlorobenzene & Conservative 5.0E-08 \\
\hline 1,2 Dichloroethane & Conservative 5.0E-08 \\
\hline & \\
\hline
\end{tabular}




\section{B.5 References}

Allison, J. D., D. S. Brown, and K. J. Novo-Gradac. 1991. MINTEQA2/PRODEFA2, A Geochemical Assessment Model for Environmental Systems: Version 3.0 User's Manual. EPA/600/3-91/021, U.S. Environmental Protection Agency, Athens, Georgia.

Atkins, M., and F. P. Glasser. 1992. "Application of Portland Cement-Based Materials to Radioactive Waste Immobilization." Waste Management 12:105-131.

Atkins, M., J. Cowie, F. P. Glasser, T. Jappy, A. Kindness, and C. Pointer. 1990. "Assessment of the Performance of Cement-Based Composite Material for Radioactive Waste Immobilization." In Scientific Basis for Nuclear Waste Management XIII, V. M. Oversby and P. W. Brown (eds.). Materials Research Society Symposium Proceedings, Volume 176, Pittsburgh, Pennsylvania, pp. 117-127.

Atkins, M., F. P. Glasser, and L. P. Moroni. 1991. "The Long-Term Properties of Cement and Concretes." In Scientific Basis for Nuclear Waste Management XIV, T. A. Abrajano, Jr., and L. H. Johnson (eds.). Materials Research Society Symposium Proceedings, Volume 212, Pittsburgh, Pennsylvania, pp. 373-386.

Brookins, D. G. 1984. Geochemical Aspects of Radioactive Waste Disposal. Springer-Verlag Publishing, New York, 347 p.

Criscenti, L. J., and R. J. Serne. 1990. "Thermodynamic Modeling of Cement/Groundwater Interactions as a Tool for Long-Term Performance Assessment." In Scientific Basis for Nuclear Waste Management XIII, V. M. Oversby and P. W. Brown (eds.). Materials Research Society Symposium Proceedings, Volume 176, Pittsburgh, Pennsylvania, pp. 81-89.

Davis, E. C. , W. J. Boegly, E. R. Rothschild, B. P. Spaulding, N. D. Vaughan, C. S. Hasse, D. D. Huff, S. Y. Lee, E. C. Walls, J. D. Newbold, and E. D. Smith. 1984. Site Characterization Techniques Used at a Low-Level Waste Shallow Land Burial Field Demonstration Facility. ORNL/TM-9146, Oak Ridge National Laboratory, Oak Ridge, Tennessee.

Duerden, S. L., A. J. Majumdar, and P. L. Walton. 1990. "Durability of Blended Cements in Contact with Sulphate-Bearing Ground Water." In Scientific Basis for Nuclear Waste Management XIII, V. M. Oversby and P. W. Brown (eds.). Materials Research Society Symposium Proceedings, Volume 176, Pittsburgh, Pennsyivania, pp. 157-164.

Environmental Protection Group. 1994. Environmental Surveillance at Los Alamos During 1992. LA-12764-ENV, Los Alamos National Laboratory, Los Alamos, New Mexico. 
Ewart, F. T., R. M. Howse, H. P. Thomason, S. J. Williams, and J. E. Cross. 1986. "The Solubility of Actinides in the Near-Field." Mat. Res. Soc. Symp. Proc. 50:701-708.

Ewart, F. T., J. L. Smith-Briggs, H. P. Thomason, and S. J. Williams. 1992. "The Solubility of Actinides in a Cementitious Near-Field Environment." Waste Management 12:241-252.

Garrels, R. M., and C. L. Christ. 1965. Solutions, Minerals, and Equilibria. Freeman, Cooper \& Company, San Francisco, California.

Grenthe, I., J. Fuger, R.J.M. Konings, R. J. Lemire, A. B. Muller, C. Nguyen-Trung, and H. Wanner. 1992. Chemical Thermodynamics Series, Volume 1: Chemical Thermodynamics of Uranium. North-Holland, Elsevier Science Publishing Company, Inc., New York.

Hietanen, R., T. Jaakkola, and J. Miettinen. 1985. "Sorption of Cesium, Strontium, Iodine, and Carbon in Concrete and Sand." In Scientific Basis for Nuclear Waste Management VIII, C. M. Jantzen, J. A. Stone, and R. C. Ewing (eds.). Materials Research Society Symposium Proceedings, Volume 44, Pittsburgh, Pennsylvania, pp. 891-898.

International Atomic Energy Agency. 1993. Improved Cement Solidification of Low and Intermediate Level Radioactive Wastes. Technical Reports Series No. 350, Vienna, Austria.

Kaplan; D. I. and R. J. Serne.. 1995. Distribution Coefficient Values Describing Iodine, Neptunium, Selenium, Technetium, and Uranium Sorption to Hanford Sediments. PNL-10379, SUP. 1, Pacific Northwest Laboratory, Richland, Washington.

Kaplan, D. I., R. J. Serne, and M. G. Piepho. 1995. Geochemical Factors Affecting Radionuclide Transport Through Near and Far Fields at a Low-Level Waste Disposal Site. PNL-10379, Pacific Northwest Laboratory, Richland, Washington.

Krupka, K. M., and R. J. Serne. 1996. Effects on Radionuclide Concentrations by Cement/Ground-Water Interactions in Support of Performance Assessment of Low-Level Radioactive Waste Disposal Facilities. NUREG/CR-6377, prepared for the U.S. Nuclear Regulatory Commission by Pacific Northwest National Laboratory, Richland, Washington.

Krupka, K. M., D. Rai, R. W. Fulton, and R. G. Strickert. 1985. "Solubility Data for U(VI) Hydroxide and Np(IV) Hydrous Oxide: Application of MCC-3 Methodology." In Scientific Basis for Nuclear Waste Management VIII, C. M. Jantzen, J. A. Stone, and R. C. Ewing (eds.). Materials Research Society Symposium Proceedings, Volume 44, Pittsburgh, Pennsylvania, pp. 753-760.

Lindsay, W. L. 1979. Chemical Equilibria in Soils. John Wiley \& Sons, New York. 
Looney, B. B., M. W. Grant, and C. M. King. 1987. Estimation of Geochemical Parameters for Assessing Subsurface Transport at the Savannah River Plant. DPST-85-904, Savannah River Laboratory, Aiken, South Carolina.

Morel, F.M.M. 1983. Principles of Aquatic Chemistry. John Wiley \& Sons, New York.

Nordstrom, D. K., and J. L. Munoz. 1985. Geochemical Thermodynamics. The Benjamin/Cummings. Publishing Co., Inc., Menlo Park, California.

Reardon, E. J. 1992. "Problems and Approaches to the Prediction of the Chemical Composition in Cement/Water Systems." Waste Mánagement 12:221-239.

Reardon, E. J., and P. Dewaele. 1990. "Chemical Model for the Carbonation of a Grout/Water Slurry." Journal of the American Ceramic Society 73:1681-1690.

Savannah River Laboratory. 1985. Environmental Information Document - F Area Seepage Basins. DPST-85-704, E. I. du Pont de Nemours \& Co., Savannah River Laboratory, Aiken, South Carolina.

Serne, R. J. and M. I. Wood. 1990. Hanford Waste-Form Release and Sediment Interaction. PNL-7297, Pacific Northwest Laboratory, Richland, Washington.

Serne, R. J., J. L. Conca, V. L. LeGore, K. J. Cantrell, C. W. Lindenmeier, J. A. Campbell, J. A. Amonette, and M. I. Wood. 1993. Solid-Waste Leach Characteristics and ContaminantSediment Interactions. Vol. 1: Batch Leach and Adsorption Tests and Sediment Characterization. PNL-8889, Pacific Northwest Laboratory, Richland, Washington.

Sheppard, M. I., D. I. Beals, D. H. Thibault, and P. O'Conner. 1984. Nuclide Distribution Coefficients and Their Statistical Distribution. AECL-8346, Atomic Energy of Canada Limited, Whiteshell Nuclear Research Establishment, Pinawa, Manitoba.

Sheppard, M. I., and D. H. Thibault. 1990. "Default Soil/Liquid Partition Coefficients, Kds, for Four Major Soil Types: A Compendium." Health Physics 59:471-482.

Smith, R. W., and J. C. Walton. 1991. "The Effects of Calcite Solid Solution Formation on the Transient Release of Radionuclides from Concrete Barriers." In Scientific Basis for Nuclear Waste Management XIV, T. A. Abrajano, Jr. and L. H. Johnson (eds.). Materials Research Society Symposium Proceedings, Volume 212, Pittsburgh, Pennsylvania, pp. 403-409.

Strenge, D. L. and S. R. Peterson. 1989. Chemical Data Bases for the Multimedia Environmental Pollutant Assessment System (MEPAS): Version 1. PNL-7145. Pacific Northwest Laboratory, Richland, Washington. 
Stumm, W., and J. J. Morgan. 1981. Aquatic Chemistry. An Introduction Emphasizing Chemical Equilibria in Natural Waters. John Wiley \& Sons, New York.

Triay, I. R., C. R. Cotter, S. M. Kraus, M. H. Huddleston, S. J. Chipera, and D. L. Bish. 1994. Report on Radionuclide Sorption in Yucca Mountain Tuffs with J-13 Well Water: Neptunium, Uranium, and Plutonium. Milestone \#3338, Los Alamos National Laboratory, Los Alamos, New Mexico.

U.S. Department of Energy (DOE). 1995. Waste Isolation Pilot Plant Safety Analysis Report. DOE/WIPP-95-2065, Revision 1, November, Carlsbad, New Mexico.

Wolfsberg, K. 1980. "Sorptive Properties of Tuff and Nuclide Transport and Retardation." In Evaluation of Tuff as a Medium for Nuclear Waste Repository: Interim Status Report on the Properties of Tuff. J. K. Johnstone and K. Wolfsberg (eds.) SAND80-1464, Sandia National Laboratories, Albuquerque, New Mexico. 


\section{Appendix C}

Waste Form Data 


\section{Appendix C}

\section{Waste Form Data}

This appendix contains waste form data for each șite. These data are broken down into two tables: one for contact handled wastes and a second for remote handled wastes.

C.1 
Table C.1. CH TRU Final Waste Form Data

\begin{tabular}{|c|c|c|c|c|c|}
\hline Site & Final Waste Form & Type $^{(a)}$ & $\begin{array}{l}\text { Stored Volume } \\
\left(\mathrm{m}^{3}\right)\end{array}$ & $\begin{array}{c}\text { Protected } \\
\text { Volume }\left(\mathbf{m}^{\mathbf{3}}\right)\end{array}$ & $\begin{array}{c}\text { Average } \\
\text { Density } \\
\left(\mathbf{k g} / \mathbf{m}^{3}\right)\end{array}$ \\
\hline \multirow[t]{4}{*}{ ANL-E } & Lead/cadmium metal & CH MTRU & 1.1 & 1.3 & 330.0 \\
\hline & Solidified inorganics & CH MTRU & 5.2 & 0.0 & 355.4 \\
\hline & Solidified organics & CH MTRU & 0.2 & 0.0 & . $\quad 697.2$ \\
\hline & Uncategorized metal & CH TRU & 5.0 & 128.5 & 302.9 \\
\hline \multirow[t]{5}{*}{ ANL-W(b) } & Combustible & CH MTRU & 0.0 & 2.0 & 401.2 \\
\hline & Heterogeneous & CH MTRU & 1.7 & 0.0 & 512.3 \\
\hline & Combustible & $\mathrm{CH}$ TRU & 0.0 & 99.6 & 401.2 \\
\hline & Heterogeneous & CH TRU & 4.8 & 345.4 & 512.3 \\
\hline & Uncategorized metal & CH TRU & 0.0 & 293.8 & 423.7 \\
\hline \multirow[t]{8}{*}{ Hanford } & Combustible & CH MTRU & 455.7 & 1247.3 & 133.9 \\
\hline & Lead/cadmium metal & CH MTRU & 14.2 & 34.5 & 328.2 \\
\hline & Solidified organics & CH MTRU & 7.4 & 9.4 & 160.7 \\
\hline & Uncategroized metal & CH MTRU & 444.9 & $19,635.2$ & 419.4 \\
\hline & Heterogeneous & CH TRU & $11,190.8$ & 6271.3 & 865.5 \\
\hline & Inorganic nonmetal & CH TRU & 34.7 & 69.1 & 204.7 \\
\hline & Soils & CH TRU & 119.5 & 5961.7 & 635.7 \\
\hline & Solidified inorganics & CH TRU & 12.9 & 7.1 & 432.5 \\
\hline \multirow[t]{7}{*}{ INEL } & Filter & CH MTRU & 131.0 & 0.0 & 96.6 \\
\hline & Inorganic nonmetal & CH MTRU & $2,066.1$ & 0.0 & $1,827.6$ \\
\hline & Solidified organics & CH MTRU & 789.7 & 0.0 & 894.9 \\
\hline & Inorganic nonmetal & CH TRU & 853.6 & 0.0 & $2,463.3$ \\
\hline & Combustible & CH MTRU & $3,239.2$ & 0.0 & 725.8 \\
\hline & Graphite & CH MTRU & 410.6 & 0.0 & 310.9 \\
\hline & Heterogeneous & CH MTRU & $6,334.2$ & 0.0 & 415.5 \\
\hline
\end{tabular}

C. 2 
Table C.1. (contd)

\begin{tabular}{|c|c|c|c|c|c|}
\hline Site & Final Waste Form & Type $^{(a)}$ & $\begin{array}{l}\text { Stored Volume } \\
\qquad\left(\mathrm{m}^{\mathbf{3}}\right)\end{array}$ & $\begin{array}{c}\text { Protected } \\
\text { Volume }\left(\mathrm{m}^{3}\right)\end{array}$ & $\begin{array}{l}\text { Average } \\
\text { Density } \\
\left(\mathrm{kg} / \mathrm{m}^{3}\right)\end{array}$ \\
\hline \multirow{9}{*}{$\begin{array}{l}\text { INEL } \\
\text { (contd) }\end{array}$} & Lead/cadmium metal & CH MTRU & .14 .4 & 0.0 & 313.5 \\
\hline & Salt & CH MTRU & 8.8 & 0.0 & 203.6 \\
\hline & Solidified inorganics & CH MTRU & $3,991.7$ & 0.0 & 674.6 \\
\hline & Uncategorized metal & CH MTRU & $5,789.8$ & 0.0 & 306.3 \\
\hline & Combustible & CH TRU & 65.8 & 0.0 & 280.3 \\
\hline & Graphite & CH TRU & 87.6 & 0.0 & 338.8 \\
\hline & Heterogeneous & CH TRU & $4,274.3$ & 0.0 & 318.1 \\
\hline & Salt & CH TRU & 11.7 & 0.0 & 318.3 \\
\hline & Uncategorized metal & CH TRU & 77.1 & 0.0 & 403.6 \\
\hline \multirow[t]{9}{*}{ LANL } & Combustible & CH MTRU & 266.3 & 698.9 & 354.1 \\
\hline & Solidified inorganics & CH MTRU & $4,883.2$ & 1952.3 & $1,248.3$ \\
\hline & Uncategorized metal & CH MTRU & $2,561.9$ & 1118.2 & 417.7 \\
\hline & Combustible & CH TRU & $1,555.2$ & 1677.3 & 354.1 \\
\hline & Heterogeneous & CH TRU & 16.0 & 29.1 & 346.3 \\
\hline & Soils & CH TRU & 110.6 & 29.1 & $1,200.0$ \\
\hline & Solidified inorganics & CH TRU & 5.0 & 81.5 & $1,004.8$ \\
\hline & Solidified Organics & CH TRU & 1.5 & 29.1 & $1,296.0$ \\
\hline & Uncategorized metal & $\mathrm{CH}$ TRU & $1,652.5$ & 1735.6 & 525.0 \\
\hline \multirow[t]{5}{*}{ LLNL } & Heterogeneous & CH MTRU & 8.6 & 0.0 & 221.3 \\
\hline & Solidified organics & CH MTRU & 1.0 & 5.8 & 268.0 \\
\hline & Filter & CH TRU & 15.5 & 32.3 & 213.9 \\
\hline & Heterogeneous & CH TRU & 190.2 & 663.8 & .165 .3 \\
\hline & Salt & CH TRU & 0.6 & 3.0 & 342.0 \\
\hline
\end{tabular}

C.3 
Table C.1. (contd)

\begin{tabular}{|c|c|c|c|c|c|}
\hline Site & Final Waste Form & Type $^{(a)}$ & $\begin{array}{l}\text { Stored Volume } \\
\qquad\left(\mathbf{m}^{3}\right)\end{array}$ & $\begin{array}{c}\text { Protected } \\
\text { Volume }\left(\mathbf{m}^{3}\right)\end{array}$ & $\begin{array}{l}\text { Average } \\
\text { Density } \\
\left(\mathrm{kg} / \mathrm{m}^{3}\right)\end{array}$ \\
\hline $\begin{array}{l}\text { LLNL } \\
\text { (contd) }\end{array}$ & Solidified inorganics & CH TRU & 14.4 & $5.8^{\circ}$ & 268.0 \\
\hline \multirow[t]{8}{*}{ Mound } & Combustible & CH MTRU & 1.7 & 0.0 & 401.2 \\
\hline & Solidified inorganics & CH MTRU & 1.9 & 0.0 & $1,074.6$ \\
\hline & Combustible & CH TRU & 5.4 & 0.0 & 401.2 \\
\hline & Filter & CH TRU & 0.8 & 0.0 & 96.0 \\
\hline & Heterogeneous & CH TRU & 0.6 & 0.0 & 512.3 \\
\hline & Solids & CH TRU & 177.2 & 0.0 & 846.8 \\
\hline & Solidified inorganics & CH TRU & 4.2 & 0.0 & $1,143.0$ \\
\hline & Uncategorized metal & CH TRU & 82.5 & 0.0 & 423.7 \\
\hline \multirow[t]{2}{*}{ NTS } & Heterogeneous & CH MTRU & 613.3 & 9.0 & 225.2 \\
\hline & Solidified inorganics & $\mathrm{CH}$ TRU & 5.7 & 0.0 & $272.0^{\prime}$ \\
\hline \multirow[t]{2}{*}{ ORNL } & Heterogeneous & CH MTRU & 697.6 & 256.3 & 251.8 \\
\hline & Heterogeneous & CH TRU & 606.5 & 0.0 & 251.8 \\
\hline \multirow[t]{9}{*}{ RFETS } & Combustible & CH MTRU & 151.4 & 736.5 & 131.2 \\
\hline & Filter & CH MTRU & 2.1 & 325.4 & 84.9 \\
\hline & Heterogeneous & CH MTRU & 1.2 & 0.0 & 362.0 \\
\hline & Inorganic nonmetal & CH MTRU & 16.5 & 291.7 & 249.8 \\
\hline & Lead/cadmium metal & CH MTRU & 4.0 & 298.3 & 245.2 \\
\hline & Solidified inorganics & CH MTRU & 150.2 & 1193.3 & 714.9 \\
\hline & Solidified organics & CH MTRU & 109.8 & 0.0 & 983.5 \\
\hline & Uncategorized metal & CH MTRU & 1.5 & $0.0^{5}$ & 215.5 \\
\hline & Combustible & CH TRU & 34.1 & 124.6 & 79.5 \\
\hline
\end{tabular}

C. 4 
Table C.1. (contd)

\begin{tabular}{|c|c|c|c|c|c|}
\hline Site & Final Waste Form & Type $^{(\mathrm{a})}$ & $\begin{array}{l}\text { Stored Volume } \\
\qquad\left(\mathbf{m}^{3}\right)\end{array}$ & $\begin{array}{c}\text { Protected } \\
\text { Volume }\left(\mathbf{m}^{3}\right)\end{array}$ & $\begin{array}{c}\text { Average } \\
\text { Density } \\
\left(\mathrm{kg} / \mathrm{m}^{3}\right)\end{array}$ \\
\hline \multirow{2}{*}{$\begin{array}{l}\text { RFETS } \\
\text { (contd) }\end{array}$} & Filter & CH TRU & 70.0 & 152.2 . & 90.5 \\
\hline & Graphite & CH TRU & 13.7 & 47.6 & 279.1 \\
\hline \multirow{6}{*}{$\begin{array}{l}\text { RFETS } \\
\text { (contd) }\end{array}$} & Heterogeneous & CH TRU & 2.6 & 0.0 & 370.8 \\
\hline & Inorganic nonmetal & $\mathrm{CH}$ TRU & 41.8 & 575.0 & 219.0 \\
\hline & Salt & CH TRU & 0.0 & 325.9 & 536.4 \\
\hline & Solidified inorganics & CH TRU & 15.2 & 64.3 & 685.4 \\
\hline & Solidified organics & CH TRU & 0.0 & 31.1 & 349.1 \\
\hline & Uncategorized metal & CH.TRU & 91.9 & 236.1 & 321.3 \\
\hline \multirow[t]{4}{*}{ SRS } & Heterogeneous & CH MTRU & $2,611.6$ & 5465.2 & 173.2 \\
\hline & Solidified inorganics & CH MTRU & 200.2 & 1.169 .6 & $2,185.5$ \\
\hline & Uncategorized metal & CH MTRU & 70.4 & 120.5 & 387.1 \\
\hline & Heterogeneous & CH TRU & 0.0 & 10.7 & 161.5 \\
\hline \multicolumn{6}{|c|}{ (a) CH MTRU denotes contact-handled mixed transuranic waste. $\mathrm{CH}$ TRU denotes contact-handled } \\
\hline
\end{tabular}


Table C.2. RH TRU Final Waste Form Data ${ }^{(a)}$

\begin{tabular}{|c|c|c|c|c|c|}
\hline Site & Final Waste Form & Type ${ }^{(0)}$ & Stored Volume $\left(\mathrm{m}^{3}\right)$ & $\begin{array}{c}\begin{array}{c}\text { Projected Volume } \\
\left(\mathrm{m}^{3}\right)\end{array} \\
\end{array}$ & $\begin{array}{c}\text { Average } \\
\text { Density }\left(\mathrm{kg} / \mathrm{m}^{3}\right) \\
\end{array}$ \\
\hline \multirow[t]{4}{*}{ ANL-W(c) } & Inorganic nonmetal & RH MTRU & 0.0 & 21.4 & 132.5 \\
\hline & Solidified inorganics & RH MTRU & 1.8 & 28.5 & $1,074.6$ \\
\hline & Heterogeneous & RH TRU & 0.0 & $1,208.6$ & 512.3 \\
\hline & Lead/cadmmium metal & RH TRU & 0.0 & 6.2 & 423.7 \\
\hline \multirow[t]{5}{*}{ Hanford } & Heterogeneous & RH MTRU & 0.0 & $2,617.5$ & 432.4 \\
\hline & Lead/cadmium metal & RH MTRU & 2.7 & 60.5 & 592.0 \\
\hline & Uncategorized metal. & RH MTRU & 0.0 & 0.0 & 519.1 \\
\hline & Heterogeneous & RH TRU & 199.4 & $1,448.9$ & 460.2 \\
\hline & Uncategorized metal & RH TRU & 0.0 & $17,400.4$ & 283.5 \\
\hline \multirow[t]{10}{*}{ INEL } & Combustible & RH MTRU & 21.4 & 0.0 & 294.0 \\
\hline & Hetrogeneous & RH MTRU & 43.9 & 0.0 & 210.3 \\
\hline & Inorganic nonmetal & RH MTRU & 33.2 & 0.0 & $1,930.6$ \\
\hline & Lead/cadmium metal & RH MTRU & 3.6 & 0.0 & 313.5 \\
\hline & Solidified inorganics & RH MTRU & 65.3 & 0.0 & 466.1 \\
\hline & Solidified Organics & RH MTRU & 3.6 & 0.0 & 842.1 \\
\hline & Uncategorized metal & RH MTRU & 22.5 & 0.0 & 221.4 \\
\hline & Hetrogeneous & RH TRU & 5.9 & 0.0 & 378.2 \\
\hline & Inorganic nonmetal & RH TRU & 13.1 & 0.0 & $2,500.0$ \\
\hline & Uncategorized metal & RH TRU & 8.3 & 0.0 & 341.5 \\
\hline \multirow[t]{4}{*}{ LANL } & Uncategorized metal & RH MTRU & 16.9 & 33.8 & 557.5 \\
\hline & Combustible & RH TRU & 15.1 & 49.0 & 354.1 \\
\hline & Heterogeneous & RH TRU & 11.6 & 0.0 & 302.9 \\
\hline & Uncategorized metal & RH TRU & 50.7 & 16.0 & 567.4 \\
\hline \multirow[t]{3}{*}{ ORNL } & Heterogeneous & RH MTRU & $1,347.5$ & 240.3 & 251.8 \\
\hline & Solidified inorganics & RH MTRU & $1,036.9$ & 206.5 & 793.3 \\
\hline & Heterogeneous & RH TRU. & 84.5 & 0.0 & 251.8 \\
\hline
\end{tabular}

C. 6 


\section{Appendix D}

Summary of Radiological Risk Results for the Intruder Scenarios 


\section{Appendix D}

\section{- Summary of Radiological Risk Results for the Intruder Scenarios}

Tables D.1 through D.6 provide a summary of radiological results for the four intruder scenarios analyzed for the No Action Alternative 2. These tables provide site- and contaminant-specific dose impacts from radionuclides for the Driller, Gardener, Scavenger, and Farm Family Intruder Scenarios. Both contact- and remote-handled TRU waste results are presented. Site-specific LCFs are provided for each intruder scenario and waste type. 
Table D.1. Summary of Radiological Risk Results for Drilling Intrusion Scenario into ContactHandled Wastes

\begin{tabular}{|c|c|c|c|c|c|}
\hline & Hanford & INEL & LANL & ORNL & SRS \\
\hline \multicolumn{6}{|c|}{ Driller (rem) } \\
\hline Co- 60 & $0.0 \mathrm{E}+00$ & $0.0 \mathrm{E}+00$ & $0.0 \mathrm{E}+00$ & $0.0 \mathrm{E}+00$ & $0.0 \mathrm{E}+00$ \\
\hline ST-90 & $3.1 E-06$ & $1.2 \mathrm{E}-07$ & $\cdot 2.3 \mathrm{E}-07$ & $7.6 \mathrm{E}-05$ & $1.6 \mathrm{E}-07$ \\
\hline$Y-90$ & $0.0 \mathrm{E}+00$ & $0.0 \mathrm{E}+00$ & $0.0 E+00$ & $0.0 \mathrm{E}+.00$ & $0.0 \mathrm{E}+00$ \\
\hline Cs-137 & 4.3E-04 & 5.1E-05 & $3.5 \mathrm{E}-05$ & $1.7 \mathrm{E}-02$ & 2.4E-05 \\
\hline Pu-238 & 2.7E-03 & $1.9 \mathrm{E}-03$ & 4.4E-03 & $1.4 \mathrm{E}-03$ & 8.3E-02 \\
\hline Pu-239 & $2.8 \mathrm{E}-03$ & $3.6 \mathrm{E}-03$ & $9.6 \mathrm{E}-03$ & $3.4 \mathrm{E}-03$ & $5.0 \mathrm{E}-03$ \\
\hline $\mathrm{Pu}-240$ & $6.4 \mathrm{E}-04$ & 8.5E-04 & $1.3 \mathrm{E}-05$ & 1.1E-03 & $1.2 \mathrm{E}-03$ \\
\hline Am-241 & $1.8 \mathrm{E}-02$ & 2.3E-01 & $4.0 \mathrm{E}-02$ & $1.1 \mathrm{E}-01$ & $9.0 \mathrm{E}-02$ \\
\hline $\mathrm{Cm}-244$ & $1.2 \mathrm{E}-05$ & $3.2 \mathrm{E}-07$ & $5.6 \mathrm{E}-08$ & $9.9 \mathrm{E}-07$ & $5.8 \mathrm{E}-08$ \\
\hline $\mathrm{U}-232$ & $0.0 \mathrm{E}+00$ & $0.0 \mathrm{E}+00$ & $0.0 \mathrm{E}+00$ & $0.0 \mathrm{E}+00$ & $0.0 \mathrm{E}+00$ \\
\hline U-233 & $0.0 \mathrm{E}+00$ & $0.0 \mathrm{E}+00$ & $0.0 \mathrm{E}+00$ & $0.0 \mathrm{E}+00$ & $0.0 \mathrm{E}+00$ \\
\hline U-234 & $0.0 \mathrm{E}+00$ & $0.0 E+00$ & $0.0 \mathrm{E}+00$ & $0.0 \mathrm{E}+00$ & $0.0 \mathrm{E}+00$ \\
\hline $\mathrm{U}-235$ & $0.0 \mathrm{E}+00$ & $0.0 \mathrm{E}+00$ & $0.0 \mathrm{E}+00$ & $0.0 \mathrm{E}+00$ & $0.0 \mathrm{E}+00$ \\
\hline U-238 & $0.0 \mathrm{E}+00$ & $0.0 \mathrm{E}+00$ & $0.0 \mathrm{E}+00$ & $0.0 \mathrm{E}+00$. & $0.0 \mathrm{E}+00$ \\
\hline Np-239 & $1.9 \mathrm{E}-05$ & $5.0 \mathrm{E}-07^{\circ}$ & $8.8 \mathrm{E}-08$ & $1.6 \mathrm{E}-06$ & 9.1Eं-08 \\
\hline Total (rem) & $2.5 \mathrm{E}-02$ & 2.4E-01 & 5.4E-02 & 1.4E-01 & $1.8 \mathrm{E}-01$ \\
\hline $\begin{array}{l}\text { Latent } \\
\text { Cancer } \\
\text { Fatality }\end{array}$ & $1.2 \mathrm{E}-05$ & 1.2E-04 & $2.7 \mathrm{E}-05$ & $6.8 \mathrm{E}-05$ & $9.0 \mathrm{E}-05$ \\
\hline
\end{tabular}


Table D.2. Summary of Radiological Risk Results for Gardener Intrusion Scenario Associated with Contact-Handled Wastes

\begin{tabular}{|l|l|l|l|l|l|l|}
\hline & Hanford & INEL & LANL & ORNL & SRS \\
\hline \multicolumn{5}{|c|}{ Gardner (rem) } \\
\hline Co-60 & $0.0 \mathrm{E}+00$ & $0.0 \mathrm{E}+00$ & $0.0 \mathrm{E}+00$ & $0.0 \mathrm{E}+00$ & $0.0 \mathrm{E}+00$ \\
\hline Sr-90 & $1.8 \mathrm{E}-03$ & $6.7 \mathrm{E}-05$ & $1.3 \mathrm{E}-04$ & $4.4 \mathrm{E}-02$ & $9.1 \mathrm{E}-05$ \\
\hline Y-90 & $9.9 \mathrm{E}-05$ & $3.7 \mathrm{E}-06$ & $7.4 \mathrm{E}-06$ & $2.4 \mathrm{E}-03$ & $5.1 \mathrm{E}-06$ \\
\hline Cs-137 & $1.8 \mathrm{E}-03$ & $2.2 \mathrm{E}-04$ & $1.5 \mathrm{E}-04$ & $7.1 \mathrm{E}-02$ & $1.0 \mathrm{E}-04$ \\
\hline Pu-238 & $2.5 \mathrm{E}-01$ & $1.7 \mathrm{E}-01$ & $4.1 \mathrm{E}-01$ & $1.2 \mathrm{E}-01$ & $7.6 \mathrm{E}+00$ \\
\hline Pu-239 & $2.6 \mathrm{E}-01$ & $3.3 \mathrm{E}-01$ & $8.9 \mathrm{E}-01$ & $3.1 \mathrm{E}-01$ & $4.6 \mathrm{E}-01$ \\
\hline Pu-240 & $5.9 \mathrm{E}-02$ & $7.8 \mathrm{E}-02$ & $1.2 \mathrm{E}-03$ & $1.1 \mathrm{E}-01$ & $1.1 \mathrm{E}-01$ \\
\hline Am-241 & $1.0 \mathrm{E}-01$ & $1.3 \mathrm{E}+00$ & $2.3 \mathrm{E}-01$ & $6.4 \mathrm{E}-01$ & $5.1 \mathrm{E}-01$ \\
\hline Cm-244 & $6.8 \mathrm{E}-05$ & $1.8 \mathrm{E}-06$ & $3.2 \mathrm{E}-07$ & $5.7 \mathrm{E}-06$ & $3.3 \mathrm{E}-07$ \\
\hline U-232 & $0.0 \mathrm{E}+00$ & $0.0 \mathrm{E}+00$ & $0.0 \mathrm{E}+00$ & $0.0 \mathrm{E}+00$ & $0.0 \mathrm{E}+00$ \\
\hline U-233 & $0.0 \mathrm{E}+00$ & $0.0 \mathrm{E}+00$ & $0.0 \mathrm{E}+00$ & $0.0 \mathrm{E}+00$ & $0.0 \mathrm{E}+00$ \\
\hline U-234 & $0.0 \mathrm{E}+00$ & $0.0 \mathrm{E}+00$ & $0.0 \mathrm{E}+00$ & $0.0 \mathrm{E}+00$ & $0.0 \mathrm{E}+00$ \\
\hline U-235 & $0.0 \mathrm{E}+00$ & $0.0 \mathrm{E}+00$ & $0.0 \mathrm{E}+00$ & $0.0 \mathrm{E}+00$ & $0.0 \mathrm{E}+00$ \\
\hline U-238 & $0.0 \mathrm{E}+00$ & $0.0 \mathrm{E}+00$ & $0.0 \mathrm{E}+00$ & $.0 .0 \mathrm{E}+00$ & $0.0 \mathrm{E}+00$ \\
\hline Np-239 & $7.4 \mathrm{E}-08$ & $2.0 \mathrm{E}-09$ & $3.5 \mathrm{E}-10$ & $6.2 \mathrm{E}-09$ & $3.7 \mathrm{E}-10$ \\
\hline Total (rem) & $6.7 \mathrm{E}-01$ & $1.9 \mathrm{E}+00$ & $1.5 \mathrm{E}+00$ & $1.3 \mathrm{E}+00$ & $8.7 \mathrm{E}+00$ \\
\hline Latent & $3.4 \mathrm{E}-04$ & $9.5 \mathrm{E}-04$ & $7.6 \mathrm{E}-04$ & $6.5 \mathrm{E}-04$ & $4.4 \mathrm{E}-03$ \\
\hline Cancer & & & & & \\
Fatality & & &. & & \\
\hline
\end{tabular}

D.3 
Table D.3. Summary of Radiological Risk Results for Drilling Intrusion into Remote-Handled Wastes

\begin{tabular}{|c|c|c|c|c|}
\hline - & Hanford & INEL & LANL & ORNL \\
\hline \multicolumn{5}{|c|}{ Driller (rem) } \\
\hline Co-60 & $0.0 \mathrm{E}+00$ & $0.0 \mathrm{E}+00$ & $0.0 \mathrm{E}+00$ & $0.0 \mathrm{E}+00$ \\
\hline Sr-90 & $1.9 \mathrm{E}-03$ & 1.7E-03 & $7.6 \mathrm{E}-05$ & 9.6E-04 \\
\hline$Y-90$ & $0.0 \mathrm{E}+00$ & $0.0 \mathrm{E}+00$ & $0.0 \mathrm{E}+00$ & $0.0 \mathrm{E}+00$ \\
\hline Cs-137 & $2.8 \mathrm{E}-01$ & $1.1 \mathrm{E}-01$ & 1.2E-02 & $3.8 \mathrm{E}-02$ \\
\hline Pu-238 & $1.0 \mathrm{E}-04$ & $8.3 E-05$ & $1.8 \mathrm{E}-05$ & $1.1 \mathrm{E}-05$ \\
\hline Pu-239 & 2.3E-03 & $5.2 \mathrm{E}-04$ & $1.4 \mathrm{E}-03$ & 7.2E-05 \\
\hline Pu-240 & 1.1E-03 & 2.1E-04 & $0.0 \mathrm{E}+00$ & 6.0E-06 \\
\hline Am-241 & $6.9 \mathrm{E}-02$ & $1.8 \mathrm{E}-02$ & 1.7E-06 & $4.6 \mathrm{E}-03$ \\
\hline $\mathrm{Cm}-244$ & $0.0 \mathrm{E}+00$ & $8.8 \mathrm{E}-05$ & $0.0 \mathrm{E}+00$ & $5.9 \mathrm{E}-05$ \\
\hline U-232 & $0.0 \mathrm{E}+00$ & $0.0 \mathrm{E}+00$ & $0.0 \mathrm{E}+00$ & $0.0 \mathrm{E}+00$ \\
\hline U-233 & $0.0 \mathrm{E}+00$ & $0.0 \mathrm{E}+00$ & $0.0 \mathrm{E}+00$ & $0.0 \mathrm{E}+00$ \\
\hline U-234 & $0.0 \mathrm{E}+00$ & $0.0 \mathrm{E}+00$ & $0.0 \mathrm{E}+00$ & $0.0 \mathrm{E}+00$ \\
\hline $\mathrm{U}-235$ & $0.0 \mathrm{E}+00$ & $0.0 \mathrm{E}+00$ & $0.0 \mathrm{E}+00$ & $0.0 \mathrm{E}+00$ \\
\hline $\mathrm{U}-238$ & $0.0 \mathrm{E}+00$ & $0.0 \mathrm{E}+00$ & $0.0 \mathrm{E}+00$ & $0.0 \mathrm{E}+00$ \\
\hline Np-239 & $0.0 \mathrm{E}+00$ & $0.0 \mathrm{E}+00$ & $0.0 \mathrm{E}+00$ & $0.0 \mathrm{E}+00$ \\
\hline Total (rem) & $3.6 \mathrm{E}-01$ & $1.4 \mathrm{E}-01$ & $1.3 \mathrm{E}-02$ & 4.4E-02 \\
\hline $\begin{array}{l}\text { Latent Cancer } \\
\text { Fatality }\end{array}$ & $1.8 \mathrm{E}-04$ & $6.8 \mathrm{E}-05$ & $6.5 \mathrm{E}-06$ & $2.2 \mathrm{E}-05$ \\
\hline
\end{tabular}

D. 4 
Table D.4. Summary of Radiological Risk Results for Gardener Intruder Scenario for RemoteHandled Wastes

\begin{tabular}{|c|c|c|c|c|}
\hline & Hanford & INEL & LANL & ORNL \\
\hline \multicolumn{5}{|c|}{ Gardener (rem) } \\
\hline Co- 60 & $0.0 \mathrm{E}+00$ & $0.0 \mathrm{E}+00$ & $0.0 \mathrm{E}+00$ & $0.0 \mathrm{E}+00$ \\
\hline $\mathrm{Sr}-90$ & $1.1 E+00$ & $9.6 \mathrm{E}-01$ & $4.0 \mathrm{E}-02$ & $5.5 \mathrm{E}-01$ \\
\hline$Y-90$ & $6.0 \mathrm{E}-02$ & $5.4 \mathrm{E}-02$ & 2.4E-03 & $3.1 \mathrm{E}-02$ \\
\hline Cs-137 & $1.2 E+00$ & 4.9E-01 & 5.0E-02 & $1.6 \mathrm{E}-01$ \\
\hline $\mathrm{Pu}-238$ & $9.4 E-03$ & $7.6 \mathrm{E}-03$ & 1.7E-03 & 9.7E-04 \\
\hline $\mathrm{Pu}-239$ & 2.1E-01 & 4.8E-02. & $1.2 \mathrm{E}-01$ & $6.7 \mathrm{E}-03$ \\
\hline Pu-240 & 1.0E-01 & $1.9 \mathrm{E}-02$ & $0.0 \mathrm{E}+00$ & $5.5 \mathrm{E}-04$ \\
\hline Am-241 & 3.9E-01 & $1.0 \mathrm{E}-01$ & 9.7E-06 & $2.6 \mathrm{E}-02$ \\
\hline $\mathrm{Cm}-244$ & $0.0 \mathrm{E}+00$ & 5.1E-04 & $0.0 \mathrm{E}+00$ & $3.4 \mathrm{E}-04$ \\
\hline$U-232$ & $0.0 \mathrm{E}+00$ & $0.0 E+00$ & $0.0 \mathrm{E}+00$ & $0.0 \mathrm{E}+00$ \\
\hline U-233 & $0.0 \mathrm{E}+00$ & $0.0 \mathrm{E}+00$ & $0.0 \mathrm{E}+00$ & $0.0 \mathrm{E}+0.0$ \\
\hline U-234 & $0.0 \mathrm{E}+00$ & $0.0 E+00$ & $0.0 E+00$ & $0.0 E+00$ \\
\hline U-235 & $0.0 \mathrm{E}+00$ & $0.0 \mathrm{E}+00$ & $0.0 \mathrm{E}+00$ & $0.0 \mathrm{E}+00$ \\
\hline $\mathrm{U}-238$ & $0.0 \mathrm{E}+00$ & $0.0 E+00$ & $0.0 E+00$ & $0.0 \mathrm{E}+00$ \\
\hline Np-239 & $0.0 \mathrm{E}+00$ & $0.0 E+00$ & $0.0 \mathrm{E}+00$ & $0.0 E+00$ \\
\hline Total (rem) & $3.1 E+00$ & $1.7 E+00$ & $2.2 \mathrm{E}-01$ & 7.8E-01 \\
\hline $\begin{array}{l}\text { Latent Cancer } \\
\text { Fatality }\end{array}$ & $1.5 \mathrm{E}-03$ & $8.4 \mathrm{E}-04$ & 1.1E-04 & $3.9 \mathrm{E}-04$ \\
\hline
\end{tabular}


Table D.5. Summary of Radiological Impacts for Scavenger Intrusion Scenario into Surface-Stored Wastes

\begin{tabular}{|c|c|c|c|c|c|c|c|}
\hline & Hanford & INEL & LLNL & LANL & ORNL & RFETS & SRS \\
\hline \multicolumn{8}{|c|}{ Contact-Handled Waste Impacts (rem) } \\
\hline Sr-90 & $1.5 \mathrm{E}-05$ & $5.5 \dot{\mathrm{E}}-07$ & $1.2 \mathrm{E}-07$ & $1.1 \mathrm{E}-06$ & $3.6 \mathrm{E}-04$ & $1.0 \mathrm{E}-10$ & 7.5E-07 \\
\hline Y-90 & $9.9 \mathrm{E}-05$ & 3.7E-06 & $7.1 \mathrm{E}-08$ & 7.3E-06 & $2.4 \mathrm{E}-03$ & $1.0 \mathrm{E}-10$ & $5.0 \mathrm{E}-06$ \\
\hline Cs-137 & $1.1 \mathrm{E}-02$ & $1.3 \mathrm{E}-03$ & 3.4E-05 & $8.6 \mathrm{E}-04$ & $4.2 \mathrm{E}-01$ & $1.0 \mathrm{E}-10$ & 5.9E-04 \\
\hline $\mathrm{Pu}-238$ & $7.5 \mathrm{E}-01$ & 5.2E-01 & $2.4 \mathrm{E}-03$ & $1.2 \mathrm{E}+00$ & 3.7E-01 & $1.1 \mathrm{E}-01$ & $2.3 \mathrm{E}+01$ \\
\hline Pu-239 & 7.7E-01 & $9.8 \mathrm{E}-01$ & $2.6 \mathrm{E}-03$ & $2.7 \mathrm{E}+00$ & $9.5 \mathrm{E}-01$ & $7.5 E+00$ & $1.4 \mathrm{E}+00$ \\
\hline $\mathrm{Pu}-240$ & $1.8 \mathrm{E}-01$ & 2.3E-01 & $5.9 \mathrm{E}-04$ & $3.5 \mathrm{E}-03$ & 3.2E-01 & $2.3 E+00$ & $3.4 \mathrm{E}-01$ \\
\hline Am-241 & $2.9 \mathrm{E}-01$ & $3.7 \mathrm{E}+00$ & $6.9 \mathrm{E}-02$ & $6.4 \mathrm{E}-01$ & $1.8 \mathrm{E}+00$ & $1.1 \mathrm{E}+01$ & $1.4 \mathrm{E}+00$ \\
\hline $\mathrm{Cm}-244$ & $1.9 \mathrm{E}-04$ & 5.0E-06 & $2.4 \mathrm{E}-05$ & 8.9E-07 & 1.6E-05 & 1.9E-18 & $9.2 \mathrm{E}-07$ \\
\hline $\mathrm{U}-233$ & $2.3 E-05$ & 9.9E-07. & 4.1E-08 & $8.0 \mathrm{E}-06$ & 2.0E-06 & $2.5 \mathrm{E}-09$ & $3.9 E-07$ \\
\hline Total & $2.0 E+00$ & $5.4 \mathrm{E}+00$ & 7.5E-02 & $4.5 \mathrm{E}+00$ & $3.9 \mathrm{E}+00$ & $2.1 E+01$ & $2.6 \mathrm{E}+01$ \\
\hline $\begin{array}{l}\text { Latent Cancer } \\
\text { Fatality }\end{array}$ & $1.0 \mathrm{E}-03$ & $2.8 \mathrm{E}-03$ & $3.8 \mathrm{E}-05$ & 2.3E-03 & $2.0 \mathrm{E}-03$ & $1.0 \mathrm{E}-02$ & $1.3 \mathrm{E}-02$ \\
\hline \multicolumn{8}{|c|}{ Remote-Handled Waste Impacts (rem) } \\
\hline & Hanford & INEL & LANL & ORNL & & & \\
\hline Sr-90 & $2.8 \mathrm{E}-02$ & $1.1 \mathrm{E}-02$ & $1.1 \mathrm{E}-03$ & $1.2 \mathrm{E}-02$ & & & \\
\hline$Y-90$ & $1.9 \mathrm{E}-01$ & 7.4E-02 & 7.7E-03 & 8.3E-02 & & & \\
\hline Cs-137 & $2.2 \mathrm{E}+01$ & $3.7 \mathrm{E}+00$ & 8.9E-01 & $2.6 \mathrm{E}+00$ & & & \\
\hline $\mathrm{Pu}-238$ & $4.8 \mathrm{E}-02$ & $1.6 \mathrm{E}-02$ & $8.6 \mathrm{E}-03$ & 3.7E-03 & & & \\
\hline Pu-239 & $8.1 \mathrm{E}-01$ & 8.1E-02 & $4.8 \mathrm{E}-01$ & 3:0E-02. & & & \\
\hline $\mathrm{Pu}-240$ & $4.0 \mathrm{E}-01$ & $3.2 \mathrm{E}-02$ & $0.0 \mathrm{E}+00$ & $5.2 \mathrm{E}-03$ & • & & \\
\hline Am-241 & $1.5 \mathrm{E}+00$ & $1.7 \mathrm{E}-01$ & $0.0 \mathrm{E}+00$ & $9.6 \mathrm{E}-02$ & & & \\
\hline $\mathrm{Cm}-244^{\circ}$ & $0.0 \mathrm{E}+00$ & $3.4 \mathrm{E}-03$ & $0.0 \mathrm{E}+00$ & 4.3E-03 & & & \\
\hline $\mathrm{U}-233$ & $1.4 \mathrm{E}-03$ & 1.1E-04 & 1.8E-06 & $1.6 \mathrm{E}-05$ & & & \\
\hline Total & $2.4 \mathrm{E}+01$ & $4.1 \mathrm{E}+00$ & $1.4 \mathrm{E}+00$ & $2.9 \mathrm{E}+00$ & & & \\
\hline $\begin{array}{l}\text { Latent Cancer } \\
\text { Fatality }\end{array}$ & $1.2 \mathrm{E}-02$ & 2.1E-03 & $7.0 \mathrm{E}-04$ & $1.5 \mathrm{E}-03$ & & & \\
\hline
\end{tabular}


Table D.6. Summary of Radiological Impacts for Farm Family Intrusion Scenario into Surface-Stored Wastes

\begin{tabular}{|c|c|c|c|c|c|c|c|}
\hline & Hanford & INEL & LLNL & LANL & ORNL & RFETS & SRS \\
\hline \multicolumn{8}{|c|}{ Contact-Handled Waste Impacts (rem) } \\
\hline Sr-90 & $3.4 \mathrm{E}+00$ & $1.3 \mathrm{E}-01$ & $7.5 E+03$ & $2.5 \mathrm{E}-01$ & $8.3 E+01$ & $1.0 E-10$ & 1.7E-01 \\
\hline Y-90. & $2.3 \mathrm{E}-01$ & 8.7E-03 & $3.2 \mathrm{E}+01$ & $1.7 \mathrm{E}-02$ & $5.7 E+00$ & $1.0 \mathrm{E}-10$ & $1.2 \mathrm{E}-02$ \\
\hline Cs-137 & $2.4 \mathrm{E}+00$ & 2.9E-01 & $5.8 \mathrm{E}+02$ & 2.0E-01 & $9.4 \mathrm{E}+01$ & $1.0 \mathrm{E}-10$ & $1.3 \mathrm{E}-01$ \\
\hline $\mathrm{Pu}-238$ & $2.8 \mathrm{E}+02$ & $1.9 \mathrm{E}+02$ & $4.1 \mathrm{E}+02$ & $4.5 E+02$ & $1.4 \mathrm{E}+02$ & $3.9 \mathrm{E}+01$ & $8.5 E+03$ \\
\hline $\mathrm{Pu}-239$ & $2.7 \mathrm{E}+02$ & $3.4 \mathrm{E}+02$ & $4.3 E+02$ & $9.3 \mathrm{E}+02$ & $3.3 \mathrm{E}+02$ & $2.6 \mathrm{E}+03$ & $4.8 \mathrm{E}+02$ \\
\hline Pu-240 & $6.2 \mathrm{E}+01$ & $8.2 \mathrm{E}+01$ & $9.9 \mathrm{E}+01$ & $1.2 \mathrm{E}+00$ & $1.1 \mathrm{E}+02$ & $7.8 \mathrm{E}+02$ & $1.2 \mathrm{E}+02$ \\
\hline Am-241 & $1.2 \mathrm{E}+02$ & $1.5 \mathrm{E}+03$ & $1.6 \mathrm{E}+04$ & $2.6 \mathrm{E}+02$ & $7.3 E+02$ & $4.4 \mathrm{E}+03$ & $5.8 \mathrm{E}+02$ \\
\hline $\mathrm{Cm}-244$ & 7.0E-02 & $1.9 \mathrm{E}-03$ & $4.5 \mathrm{E}+00$ & 3.4E-04 & $5.9 \mathrm{E}-03$ & $7.1 \mathrm{E}-16$ & $3.5 \mathrm{E}-04$ \\
\hline U-233 & 8.7E-03 & $3.8 \mathrm{E}-04$ & 7.2E-02 & $3.1 \mathrm{E}-03$ & 7.8E-04 & 9.7E-07 & $1.5 \mathrm{E}-04$ \\
\hline Total & $7.3 E+02$ & $2.1 \mathrm{E}+03$ & $2.5 E+04$ & $1.6 \mathrm{E}+03$ & $1.5 E+03$ & $7.8 \mathrm{E}+03$ & $9.6 \mathrm{E}+03$ \\
\hline $\begin{array}{l}\text { Latent Cancer } \\
\text { Fatality }\end{array}$ & $3.6 \mathrm{E}-01$ & $1.0 \mathrm{E}+00$ & $1.3 \mathrm{E}+01$ & 8.2E-01 & 7.4E-01 & $3.9 \mathrm{E}+00$ & $4.8 \mathrm{E}+00$ \\
\hline \multicolumn{8}{|c|}{ Remote-Handled Waste Impacts (rem) } \\
\hline & Hanford & INEL & LANL & ORNL & & & \\
\hline Sr-90 & $6.5 \mathrm{E}+03$ & $2.5 \mathrm{E}+03$ & $2.7 \mathrm{E}+02$ & $2.8 \mathrm{E}+03$ & & & \\
\hline$Y-90$ & $4.4 \mathrm{E}+02$ & $1.7 \mathrm{E}+02$ & $1.8 \mathrm{E}+01$ & $1.9 \mathrm{E}+02$ & & & \\
\hline Cs-137 & $4.9 E+03$ & $8.5 \mathrm{E}+02$ & $2.0 \mathrm{E}+02$ & $5.9 \mathrm{E}+02$ & . & & \\
\hline $\mathrm{Pu}-238$ & $1.8 \mathrm{E}+01$ & $5.9 \mathrm{E}+00$ & $3.2 \mathrm{E}+00$ & $1.4 \mathrm{E}+00$ & & & \\
\hline Pu-239 & $2.8 \mathrm{E}+02$ & $2.8 \mathrm{E}+01$ & $1.7 \mathrm{E}+02$ & $1.0 \mathrm{E}+01$ & & & \\
\hline $\mathrm{Pu}-240$ & $1.4 \mathrm{E}+02$ & $1.1 \mathrm{E}+01$ & $0.0 \mathrm{E}+00$ & $1.8 \mathrm{E}+00$ & & & \\
\hline Am-241 & $5.9 E+02$ & $6.7 \mathrm{E}+01$ & $0.0 \mathrm{E}+00$ & $3.9 \mathrm{E}+01$ & & & \\
\hline $\mathrm{Cm}-244^{\circ}$ & $0.0 \mathrm{E}+00$ & $1.3 E+00$ & $0.0 \mathrm{E}+00$ & $1.6 \mathrm{E}+00$ & & & \\
\hline $\mathrm{U}-233$ & 5.5E-01 & 4.1E-02 & $7.0 \mathrm{E}-04$ & $6.4 \mathrm{E}-03$ & & & \\
\hline Total & $1.3 E+04$ & $3.7 \mathrm{E}+03$ & $6.5 \mathrm{E}+02$ & $3.7 E+03$ & & & \\
\hline $\begin{array}{l}\text { Latent Cancer } \\
\text { Fatality }\end{array}$ & $6.4 \mathrm{E}+00$ & $1.8 \mathrm{E}+00$ & $3.3 E-01$ & $1.8 \mathrm{E}+00$ & & & \\
\hline
\end{tabular}

